\title{
CHRISTIAN RYDBERG
}

DIDAKTISKA DILEMMAN I UNDERVISNING UTIFRÅN SAMHÄLLSDILEMMAN
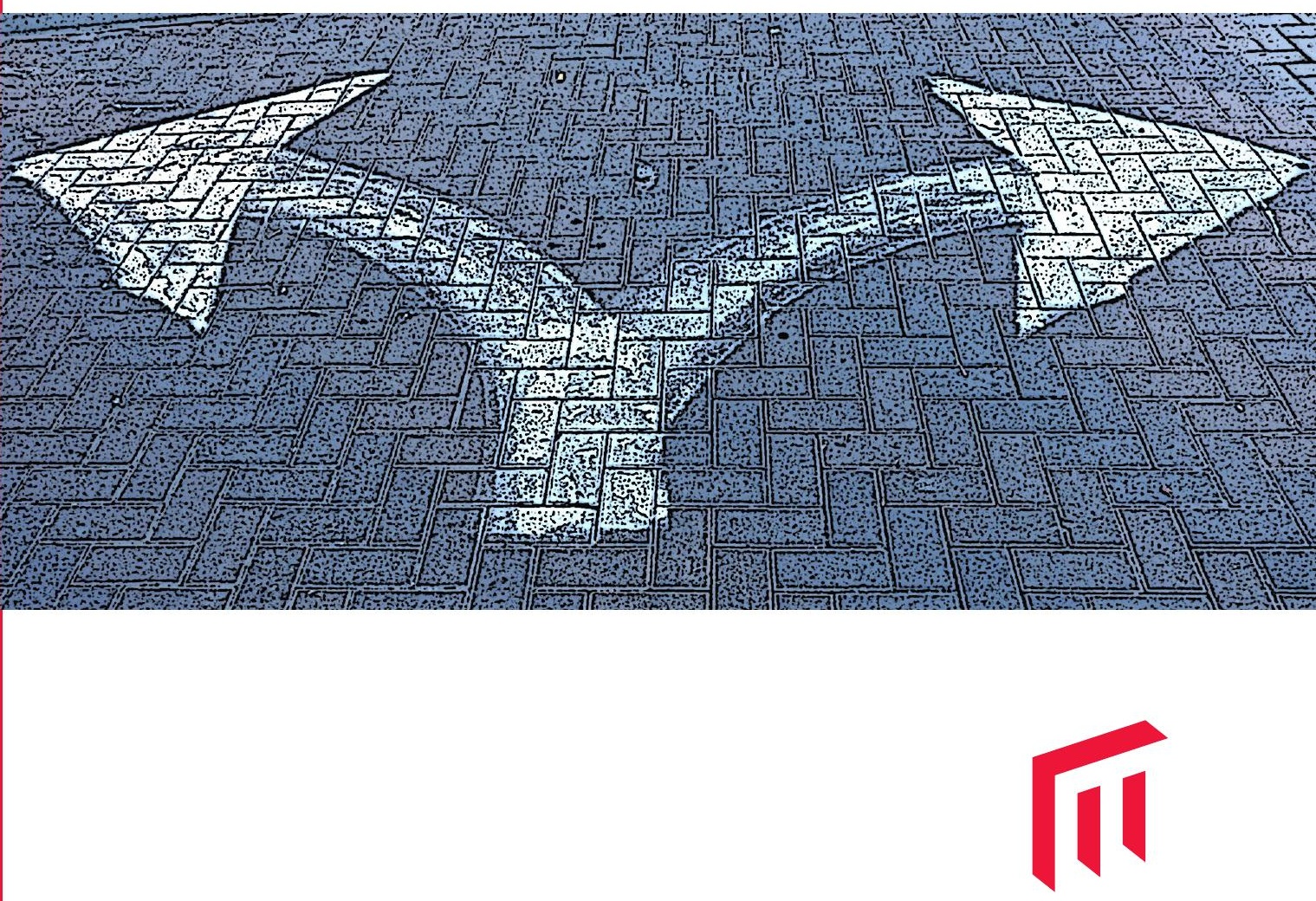

DIDAKTISKA DILEMMAN I UNDERVISNING UTIFR Å SAMHÄLLSDILEMMAN 


\section{Malmö Studies in Educational Sciences: Licentiate Dissertation Series 2018:42}

\section{Studies in Science and Technology Education No 101}

(C) Christian Rydberg 2018

Fotograf: Ze'ev Barkan

ISBN 978-9I-86295-78-3 (tryck)

ISBN 978-9I-86295-79-o (pdf)

ISSN $1653-6037$ Malmö universitet

ISSN I 652-505 I FontD

Holmbergs, Malmö 2018

Nationella forskarskolan i Naturvetenskapernas och Teknikens och matematikens didaktik, FontD, http://www.isv.liu.se/fontd, tillhör Institutionen för samhälls- och välfärdsstudier (ISV) och Utbildningsvetenskap (UV) vid Linköpings universitet. FontD är ett nätverk av följande medverkande lärosäten: universiteten i Umeå, Karlstad, Örebro, Mitt-universitetet, Linköping (värd), Göteborg, Lund, Linnéuniversitetet, Malmö samt högskolorna i Gävle, Mälardalen, Halmstad och Kristianstad.

FontD publicerar skriftserien Studies in Science and Technology Education, ISSN I 652-505 I 


\section{CHRISTIAN RYDBERG DIDAKTISKA DILEMMAN I UNDERVISNING UTIFRÅN SAMHÄLLSDILEMMAN}

Malmö universitet, 2018 Fakulteten för lärande och samhälle 
Publikationen finns även elektroniskt på:

http://dspace.mau.se/handle/204324738 
Till slut... 


\section{ABSTRACT}

Teaching and learning about complex and controversial societal issues is a challenging endeavour. Students must not only gain new scientific perspectives on the issues but also be able to take ethical and philosophical perspectives in consideration. In this teaching approach, the various aims involved are complex and the teacher often ends up in problematic situations. The teacher must also deal with formal laws and regulations in addition to more informal work routines - all whilst balancing the various teaching aims.

This study followed groups of teachers in an Erasmus+ partnership whereby the teachers conducted a reflexive and interdisciplinary lessons about certain complex and controversial issues, including those which are socio-scientific. Five schools in five different countries were involved (Croatia, Poland, Italy, Sweden and Turkey), and the students who participated were aged $12-16$ years.

With inspiration from different fields of educational research, the study aimed to induce interdisciplinary teaching about controversial issues on a structural and socio-political level at the involved schools. In addition to raising the students' awareness of different aspects of the issues and encouraging oral discussions among the students, the lesson also highlighted the development of their ability to think critically and make decisions. The lesson was also meant to create room for the students to form their own opinions about the issues. In this study, the multi-purpose teaching method in line with these intentions is labelled "reflexive teaching".

The study aimed to explore the potential tensions that may emerge during the interdisciplinary teaching in which the schools implemented this method. From these tensions, didactical dilemmas arose in the teaching, for example, when teachers held taken-for-granted 
positions or did not reflect on the complexity of different motivations when making their didactical decisions.

Through focus groups and participant observation in the participating countries, I began by asking about which tensions are discernible across the different classrooms. Then, I reduced the data and focused on Swedish teachers in light of the international context by asking "Which tensions are most salient for Swedish teachers?" These two questions were theoretically elevated and clustered in the discussion to become "Which didactical dilemmas may emerge during interdisciplinary teaching?".

The results show a variety of emerging tensions which may cause didactical dilemmas. The tensions are anchored on different levels, concern different types of curriculum goals, relate to politics and religion as well as tensions on the classroom level. Through in-depth focus-group discussions with the Swedish teachers, four so-called meta-dilemmas emerged:

1. The student-centred classroom versus the teacher-centred classroom;

2. teaching towards educational goals versus social, democratic and character-development goals;

3. whether the teacher should be objective, neutral or take a stand (regarding the complex and controversial issues); and

4. whether adaptations for specific pupils should be made in oral discussions.

The more practice-oriented purpose of the study was to contribute to pre- and in-service teacher training, and this resulted in a discussion tool. The developed tool is a didactic model which aims to raise awareness about both the potential possibilities and potential negative consequences of different positions in didactical dilemmas. By means of abductive analysis, the empirical results of the study formed the basis of a model with four quadrant matrixes. In these matrixes, different tentative positions in didactical dilemmas are illuminated by fictional teachers who present arguments about their position. 



\section{INNEHÅLL}

FÖRORD .................................................... 13

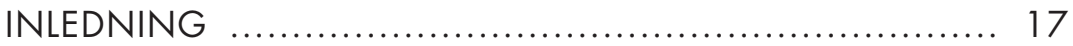

Mitt intresse för undervisningens komplexitet ...................... 18

Studiens dubbla syfte .................................................. 22

Licentiatuppsatsens struktur .............................................. 23

REFLEXIV UNDERVISNING MED UTGÅNGSPUNKT

I SAMHÄLLSDILEMMAN …............................. 27

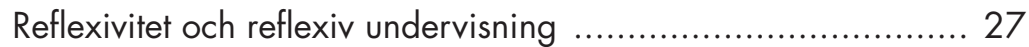

Samhällsdilemman $\mathrm{i}$ undervisningen ................................ 30

SYFTESKOMPLEXITET OCH DIDAKTISKA DILEMMAN ....... 41

Utbildningens tre huvudsyften ............................................ 41

Verksamhetsteoretiska glasögon ....................................... 45

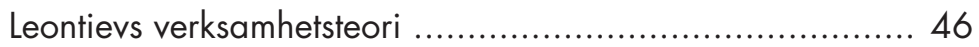

Engeströms verksamhetssystem .................................... 49

Didaktiska dilemman ......................................................... 55

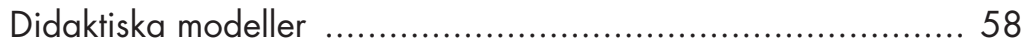

Summering av studiens teoretiska utgångspunkter ................. 60

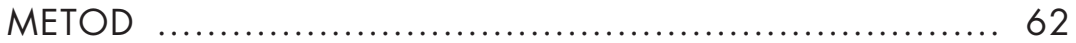

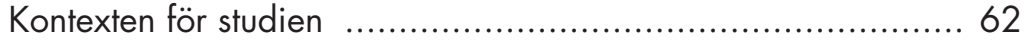

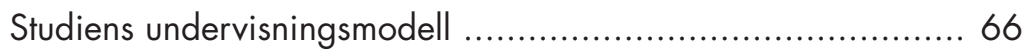

Den ämnesövergripande inriktningen ................................. 72

Studiens forskningsfrågor ............................................. 73

Metodologiska utgångspunkter ........................................... 76

Helhetsperspektiv på undervisning …........................... 76

Komparativ didaktik ............................................... 78 
Fokusgrupper och deltagande observationer ................... 79

Fyrfältsdiagram som visuell beskrivningsmodell ................ 82

Studiens tre faser .......................................................... 84

Studiens första fas ....................................................... 85

Studiens andra fas .................................................... 85

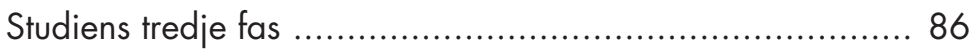

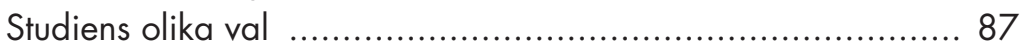

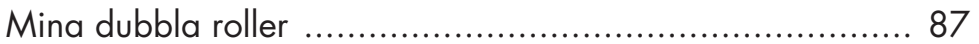

Etiska överväganden ............................................. 88

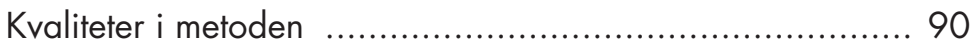

Kvaliteter i framställningen som helhet ............................ 91

Kvaliteten i resultaten .................................................... 92

Validitetskriterier .................................................. 93

FAS I - SPÄNNINGAR OCH POSITIONERINGAR ........... 95

Datainsamling under fas I .............................................. 95

Analysprocess under fas I .............................................. 99

Resultat och diskussion av studiens första fas ....................... 104

Spänningar som deltagarna upplever i den

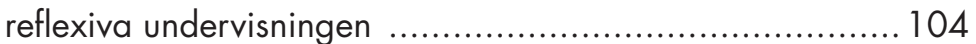

Deltagarnas positioner kring didaktiska dilemman

de upplever $i$ en reflexiv undervisning ............................ 114

Summering av studiens första fas ........................................ 138

FAS II - SPEGLINGAR I DIDAKTISKA DILEMMAN .......... 141

Datainsamlingsprocess under fas II ................................. 142

Analysprocess under fas II .......................................... 146

Resultat och diskussion av studiens andra fas ..................... 148

1. Elevcentrerade eller lärarcentrerade arbetsformer ........ 150

2. Undervisning mot bildningsmål eller utbildningsmål ....... 163

3. Om läraren ska vara objektiv, neutral eller ta ställning ... 173

4. Om anpassningar vid muntliga diskussioner ska

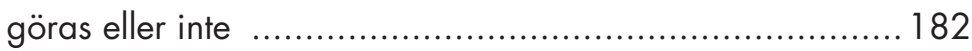

Summering av studiens andra fas ................................... 191

FAS III - VERKTYG FÖR PRAKTIKEN .......................... 195

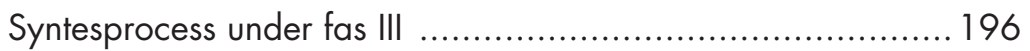

Resultat och diskussion av studiens tredje fas ...................... 199

I. Arbetsform vid faktainhämtning och diskussion ............. 202

II. Lärarens ställningstagande i diskussioner .................... 208 
III. Anpassning av diskussioner ......................................215

IV. Balans mellan bildningsmål och utbildningsmål ........... 220

Summering av fyrfältsdiagrammen ...............................227

Förslag till framtida studier av andra didaktiska dilemman ...231

SLUTDISKUSSION ............................................ 245

Spänningar och didaktiska dilemman ................................245

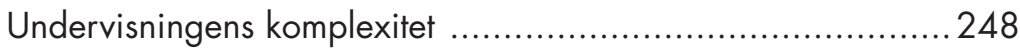

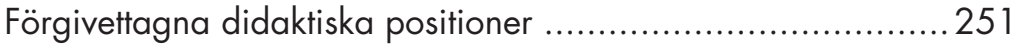

Lärarens beslutsfattande i en reflexiv undervisning ................ 252

Steg 1 - identifiera syfteskonflikter mellan positioner ........ 253

Steg 2 - balansering och prioritering av olika syften .......... 257

Steg 3 - didaktiska val i en reflexiv undervisning ............. 260

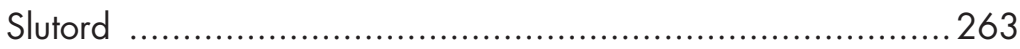

REFERENSER ............................................. 265

BILAGOR ............................................. 278 



\section{FÖRORD}

Poeten Emil Jensen reflekterade i en krönika över att för att nya rön och upptäckter ska få genomslag och bli Skavlan-kompatibla ska de vara enkla och därmed också lite extrema. Inom inlärningen har det periodvis varit talang som ensamt avgör framgången och sedan var det träning ett visst antal timmar som var det som spelade en avgörande roll. Nu säger aktuella rön att det är ihärdighet som är den hemliga formeln för framgång. Inom hälsa gäller det att ena stunden dricka mycket vatten för att må bra och det är en diet med kött och fibrer som rekommenderas. I nästa stund ska man inte äta kött och kolhydrater alls och inte dricka så mycket vatten. Denna lockelse efter en enkel lösning är troligtvis något i grunden mänskligt för visst vore det enkelt om man med 10000 timmars träning och mycket vatten garanterat skulle bli både framgångsrik och frisk. Emil Jensen sammanfattar att det som regel är lite av varje som ändå blir slutsatsen till sist. Inte otänkbart var det detta som den ursprungliga forskningen sa, innan den förenklades på sin väg ut i samhället. För det behövs nog både talang, träning, ihärdighet samt även en del yttre förutsättningar för att utveckla sina förmågor och det är nog en balanserad kost som gör att man håller sig frisk. Att verkligheten är komplex och det saknas enkla och garanterat framgångsrika genvägar är emellertid sällan något som skapar intresse och uppmärksamhet.

I denna licentiatuppsats betraktas livet som komplext och bestående av en hel massa dilemman med val att göra. Alternativen som står till buds har både möjligheter och potentiellt negativa konsekvenser. 
Om inte från vaggan till graven, så $\mathrm{i}$ alla fall perioden mellan dessa. Treåringens dilemma på förskolan kan gälla möjligheten att knycka kompisens åtråvärda docka vilket dock kan få konsekvensen att en förskolelärare tillskyndar så att leken i dockis är över för den dagen. Det är åldringen dilemma på äldreboendet där denna behöver hantera alternativet att hasa sig ut till bingospelandet i samlingsrummet och väga möjligheten till en trevlig stund mot konsekvensen av en värkande höft som stör nattsömnen.

Att genomföra denna studie och skriva denna licentiatuppsats har varit en resa där jag fått förhålla mig till olika dilemmasituationer och göra val där valet inte är hundraprocentigt tillfredsställande. Det kan vara valet att följa en beprövad forskningsdesign i sin studie eller om man ska vara mer eklektisk i sina val och ge sig ut på snårigare forskningsstigar. En beprövad vetenskaplig metod är ett säkert val där "vetenskapligheten" i resultaten är säkrare, men å andra sidan kan det mer öppna förhållningssättet öppna upp för resultat som annars inte skulle visat sig. Ett annat val att förhålla sig till är hur mycket man ska snäva av sitt forskningsfokus i den omtalade forskningstratten. En begränsning av det man studerar ger ett djup i ens resultat, men det kan bli på bekostnad av att se den helhet som resultatet är en del av. Ytterligare ett val är vem som man skriver sin uppsats för och om det aningen är en produkt primärt för övriga forskarsamhället eller om man vill inrikta sig åt praktiken, i mitt fall lärarna. I det stora är meningen med all forskning att ge nya kunskaper och öka vetandet i samhället och hos praktiken, men samtidigt är det rimligt att förmoda att synnerligen få lärare i praktiken skulle komma att läsa denna licentiatuppsats.

Ett dilemma jag upplevde var kring hur lång en monografi kan vara och den som har en tryckt version kan uppleva mitt val i detta genom att studera volym och bokens tyngdkraft. Man vill inte att en läsare inte ska tyngas med alltför mycket text innan man kommer till saken men på samma gång måste man, inte minst som licentiand, visa att ens studie både är förankrad i teori och ens slutsatser har empirisk grund. Ska man som i mitt fall beskriva en kvalitativ studie med flexibel design tränger det lite tecken för att förklara och förtydliga. 
Avvägning måste alltså göras när olika syften för texten hamnar i konflikt med varandra.

Att slukas upp av forskarstudier där det tar fyra år innan man får ett avslut ställer även en själv inför personliga dilemman. Huruvida man ska ägna närmsta timmen åt att gå och träna på Friskis eller om man ska fila lite till på texten man skriver är ett dilemma jag återkommande ställts inför. Mina val har tyvärr regelmässigt varit i förmån för texten framför min fysik, vilket blir något att åtgärda när forskarstudierna är över. Att skriva uppsats innebär även rent praktiska dilemman som vem som ska namnges i en tacktext i förordet. Givetvis har mina fyra olika handledare varit enormt viktiga och deras namn är självskrivna såväl som språkgranskare och diskutanter vid olika seminarier. I denna studie var det ett tätt samarbete med lärare på olika deltagande skolor och det är ju de som är denna forskningsstudies hjärta och så självklart ska de ha ett stort tack. Min kommun som har gett mig denna möjlighet ska tackas och givetvis även min familj så klart. Inom min forskarskola finns det personer som förtjänar tack, både lärare och medstuderanden så väl som det finns personer på Malmö universitet som förtjänar omnämnanden.

Frågan är bara var man ska dra gränsen mellan de som jag ska namnge och de som inte kommer med. Hur ska man vidare värdera olika personers bidrag till min studie? Vad gäller mina handledare har de lagt ner mycket tid och ansträngning för min skull men samtidigt var det en del av deras tjänst, även om den tid de får ersättning för troligen vida understiger den reella tiden. För de deltagande lärarna i studien var deras insatser till stor hjälp, men samtidigt gav min medverkan i detta samarbete även saker tillbaka till dem. Det är inte en enkel avvägning hur man ska värdera dessa insatserna som är tidsmässigt omfattande i förhållande till en senior forskare som förvisso bara avsatte ett par timmar men gjorde detta helt utan att få något eget utav det. På motsvarande vis kan långa diskussioner tidsmässigt med en person som kanske ha en mindre effekt för studiens utveckling, medan en kort kommentar från en seminariedeltagare kan öppna upp ens ögon på ett helt nytt vis och ha stor effekt. 
Det blir ett dilemma där om jag väljer möjligheten att namnge och uppmärksamma personer i en tackande text blir det en negativ konsekvens i och med att jag måste dra en gräns någonstans. Personer som också skulle kunna förtjäna att se sitt namn utskrivet får inte detta. Samtidigt betyder ett val att inte alls namnge personer som varit ett stort stöd, och som självklart förtjänar ett tack genom ett utskrivet namn, inte får denna erkännelse. Samtidigt innebär dilemmats natur att man måste välja ett handlingsalternativ även om det inte är helt tillfredsställande och i detta fall gör jag enligt nedan.

Jag vill tacka alla personer som i stort och smått bidragit till att denna studie har kunnat genomföras och till att licentiatuppsatsen har kunnat färdigställas. TACK! 


\section{INLEDNING}

Precis som livet i stort kan undervisning betraktas som att man kontinuerligt ställs inför en rad dilemman där olika val måste göras. Man måste välja mellan alternativ där inget är helt och hållet tillfredsställande utan det finns både för- och nackdelar med alternativen. Inom åtminstone den svenska skolan har det ofta varit att man lockats att leta efter den enkla lösningen och satsat stort när man tror sig funnit metod eller strategi som ska lösa alla problem.

Genom "eget arbete" skulle allt bli bra och när det inte fungerade blev lösningen att läraren återigen skulle stå mer vid katedern och det skulle vara mer prov och betyg. Formativ bedömning har i det närmaste betraktats som en mirakellösning och nu är det IKT och digitala lösningar som ska fixa det mesta. Alla dessa strategier har sina poänger och fördelar och alla har en funktion att fylla men de behöver samverka med varandra. Utmaningen är att få alla bitar att fungera $\mathrm{i}$ en helhet och få de ingående delarna att länkas samman och så att de får adekvat utrymme i undervisningen. Istället för att jaga de enkla lösningar kan det vara så att svensk skola ska ta ett steg tillbaka och erkänna undervisningens komplexitet.

Denna studie vill undersöka utmaningar för lärare i en ämnesövergripande undervisning utifrån komplexa och kontroversiella samhällsfrågor av dilemmakaraktär. I denna behöver eleverna få kunskaper kring frågan från olika vetenskapliga perspektiv, men även kunna se etiska och filosofiska aspekter på det hela. De samhällsdilemman som det arbetades med i studien hade en sociopolitisk dimension vilket innebar att eleverna behövde ta ställning som innebär negativa konsekvenser för någon eller något. För att hantera dessa frågor behöver eleverna utveckla olika förmågor som bygger upp ett kritiskt tänkande och det ska ges utrymme att pröva olika argument 
mot varandra i muntliga diskussioner. I undervisningen ska det vidare finnas möjligheter för eleverna att ta egen ställning kring viktiga samhällsdilemman. I denna komplexitet finns flera olika didaktiska val att göra som lärare och under studien blev jag allt mer uppmärksammad på att man som lärare gör flera av dessa utifrån förgivettagna ställningstaganden. Detta ledde till att jag i studien ville synliggöra några av dessa förgivettaganden och diskutera dem.

\section{Mitt intresse för undervisningens komplexitet}

Att helt förstå den komplexitet som finns i undervisning och hur olika delar inom denna både samverkar och motverkar varandra är inte alltid enkelt. När man arbetar som lärare finns det inte alltid tid att stanna upp och reflektera över sin praktik och för att hantera alla de beslut som måste fattas i klassrumsvardagen måste en del saker gå på rutin. Efter ett tag blir man som lärare en del av undervisningssystemet och då behövs skeenden eller händelser som ruskar om en och rubbar ens cirklar så att man kan ifrågasätta och reflektera över sin egen praktik. Jag vill illustrera tre sådana aha-upplevelser och två av dessa är från när jag arbetade som lärare medan en är från datainsamlingen i samband med denna studie. Dessa skeenden och händelser har varit avgörande för forskningsintresset i denna studie. Detta handlar om att ifrågasätta det förgivettagna i undervisningen för att upptäcka "didaktiska dilemman" och om att analysera dessa och hur de relateras till andra dilemman samt andra aktörer, normer och regler i utbildningssystemet.

Mitt intresse av att se undervisning som en del i ett större system med olika spänningar som påverkar undervisningen har sin upprinnelse flera år tillbaka. I början av 00 -talet fick jag och några kollegor möjlighet att starta upp ett helt nytt arbetslag på min dåvarande skola. Vi fick fria händer och goda resurser och samplanerade exempelvis i flera ämnen och arbetade ämnesövergripande med flexibla arbetspass, periodvis sammanhängande under så kallade temaveckor. I denna arbetsform utgick vi som regel från samhällsdilemman och undervisningen byggdes upp kring komplexa frågor. Detta är grunden till studiens intresse av en undervisning kring just samhällsdilemman där eleverna även ges utrymme att ta egen ställning. 
$\mathrm{Vi}$ arbetade även strukturerat med att utveckla elevernas generiska kompetenser och arbetade med det som senare skulle benämnas som formativ bedömning. Undervisningen uppskattades av både lärare, elever och föräldrar och även av skolledningen. Det som väckte mitt intresse för hur olika delar inom utbildningssystemet, och andra saker, påverkar undervisningens praktiska utförande var hur arbetet och undervisningen i arbetslaget utvecklades över tid. Första läsåret fanns endast en klass i arbetslaget men sedan byggdes det ut med fler klasser år efter år och i samma takt tillkom nya lärare. Efter några år var arbetslaget därmed som ett vanlig arbetslag till storleken och från att ha haft lektionssalar i en paviljong flyttades arbetslaget in $\mathrm{i}$ den ordinarie skolbyggnaden. En del av de undervisningsinnovationer som präglade första årens arbete anammades och inkluderades i hela skolans undervisning. Samtidigt började andra av de välfungerande metoderna och strategierna inom arbetslaget sakta tyna bort och undervisningen och arbetet $\mathrm{i}$ arbetslaget blev allt mer traditionellt.

Framförallt är det intressant att de av både arbetslagets lärare och elever uppskattade temaveckorna försvann. Under dessa utgick undervisningen från tvärvetenskapliga samhällsdilemman och under heldagar arbetade eleverna engagerat med olika arbetsuppgifter kopplade till dessa. I denna arbetsform utvecklades både ämneskunskaper och ämnesförmågor, men den bidrog även till elevernas bildning. I detta arbete gjordes många kopplingar till världen utanför skolan vilket gav en autenticitet till undervisningen. Trots att både lärare och elever i arbetslaget önskade arbeta vidare med detta försvann det från undervisningen. Tänkbara skäl kan vara att undervisningsinnovationer som temaveckor fungerade sämre i andra arbetslag. Förändringarna berodde även på en försämrad arbetsfördelning där flera lärare arbetade i flera arbetslag vilket gjorde arbetet mindre flexibelt. I samband med detta kom även nya skolreformer som IUP och den nya ämnesfokuserande läroplanen vilket påverkade. Dessutom skedde en del förändringar bland lärarna så väl i arbetslaget som i deras personliga liv. Detta skeende där delar av undervisningen som alla var nöjda med gradvis försvann eller tonades ner utan att någon egentligen bestämde detta väckte mitt intresse 
för en helhetssyn på undervisningen och kring vad som påverkar dess planering och utförande. Speciellt intresserar jag mig för aspekter som påverkar, och delvis förhindrar, att man arbetar mer över ämnesgränserna och där det omgivande samhället plockas in mer i undervisningen.

Denna studies objekt är fem skolor i olika europeiska länder som arbetade med att utveckla sin undervisning kring samhällsdilemman. Det gjorde de inom ramen för ett Erasmus+ skolpartnerskap. En annan avgörande händelse är från ett skolbesök på en polsk skola i samband med ett internationellt samarbete, men ett tidigare sådant. I samband med detta fick besökarna vara med på en kemilektion. Läraren hade givetvis förberett lektionen noga och med tanke på att det var besökare genomfördes den helt på engelska. Själva lektionssalen var spartanskt utrustad vad beträffar laborationsutrustning för elever och i huvudsak gjordes laborationer som demonstrationer. Lektionen handlade om olika grundämnen och läraren gick igenom olika grundämnen på tavlan och skickade runt bitar av de metaller som diskuterades. Läraren gjorde dessutom demonstrationsförsök kring några av ämnena. En tydlig minnesbild är att jag ungefär tio minuter in i lektionen tänkte att "de här eleverna lär ju sig inget för de sitter ju bara still”.

En kvart senare infann sig emellertid en annan känsla. Med denna lektion som jämförelse började jag fundera över min egen kemiundervisning kring olika grundämnen. Förvisso var eleverna i mitt klassrum aktiva och fick göra en massa roliga experiment - men vad lärde de sig egentligen? I slutet av den polska lektionen hade inte eleverna direkt fått laborera aktivt själva och kanske inte blivit helt engagerade. De hade emellertid erbjudits grundläggande kunskaper om olika grupper av grundämnen samt om deras olika egenskaper på ett mycket välstrukturerat och pedagogiskt sätt. I denna stund började jag att aktivt ifrågasätta de förgivettagna undervisningsmetoder jag själv använde mig av och jag började där och då även inse den potential som finns i att upptäcka egna förgivettaganden genom att studera liknande undervisning $i$ andra kontexter. 
Under datainsamlingen i denna studie besökte jag de olika skolorna i Erasmus+ projektet i samband med att de genomförde en temadag kring frågeställningar kopplade till ny teknik som robotar och bioteknik. Under temadagen skulle eleverna bilda sig en åsikt i utvalda frågor samt diskutera och argumentera kring olika alternativ. Den första skolan som besöktes var den svenska skolan och strax efter detta besöktes den turkiska skolan, som var den första av de utländska skolorna. Trots mina erfarenheter från den polska kemilektionen några år tidigare hade jag en förutfattad uppfattning när det gäller undervisning utifrån samhällsdilemman. Med tanke på den betydligt mer omfattande erfarenhet av sådan undervisning som de svenska lärarna hade borde rimligtvis den svenska undervisningen vara överlägsen de övrigas. Under temadagen på den turkiska skolan besökte jag fyra olika klasser med fyra olika klasslärare. På samma vis som under den polska kemilektionen tänkte jag för mig själv en bit in i den första lektionen: om nu alla lektioner på de utländska skolornas temadagar ska vara sådana här blir det kanske ingen rolig datainsamling. Undervisningen började nämligen teoretiskt och traditionellt, men snart började jag ändra uppfattning.

Trots stora klasser i små klassrum, och dessutom med lite yngre elever, lyckades nämligen dessa lärare genomföra en utmärkt undervisning. Trots begränsningar i tid fick eleverna både ta del av relevant information kring den aktuella frågan och möjlighet att formulera egna argument samt även möjligheter att diskutera både i par, i mindre grupper och i helklass. På en del sätt var denna undervisning genomförd lite annorlunda än den svenska temadagen, och som jag tänkt undervisningen i förväg. Men de didaktiska val som dessa lärare gjorde fungerade. På de övriga europeiska skolorna som jag besökte arrangerades överallt en bra undervisning under temadagarna. Precis som på den turkiska skolan gjorde lärarna en del annorlunda didaktiska val i jämförelse med de svenska lärarna. Efter dessa besök fick jag på allvar upp ögonen för att undervisning i mångt och mycket handlar om att göra didaktiska val i olika dilemmasituationer. I dessa finns flera fungerande handlingsalternativ där vart och ett innebär såväl möjligheter för elevernas lärande och personliga utveckling som potentiellt negativa konsekvenser för detsamma. När 
man som lärare gör dessa val i undervisningens vardag görs de ofta utifrån förgivettaganden.

Dessa tre ovan beskrivna episoder kan ses som grunden för mitt intresse för utmaningar och möjligheter i undervisning med utgångspunkt i samhällsdilemman. Denna licentiatuppsats är formellt inom nv-didaktik, men jag har tagit mig friheten att utvidga min studie så att den handlar om att undervisa kring naturvetenskapligt innehåll där detta möter samhällsvetenskap, teknik, politik, etik och filosofi. Detta möte sker utanför nv-klassrummets väggar och involverar även lärare i andra ämnen. För att på bästa vis belysa alla olika aspekter och för att skapa förutsättningar för eleverna att på bästa sätt utvecklas kunskapsmässigt och personligt ser jag samarbete mellan lärare från olika ämnesområden som det bästa alternativet. När man som lärare lämnar tryggheten i sina egna ämnen och ska samarbeta med andra innebär det utmaningar på olika vis. Det jag vill med min studie är att sätta in naturvetenskapen och tekniken i ett större samhällsperspektiv och inte bara begränsa mig till undervisningen i nv-klassrummet.

Tanken var att undersöka hur man kan arbeta med samhällsdilemman med naturvetenskapligt och tekniskt innehåll över ämnesgränserna och vilka utmaningar det innebär för lärarna. Precis som naturvetenskapen behöver inkludera samhällsfrågor måste samhällsorienterande ämnena och språkämnena inkludera naturvetenskap och teknik för att förbereda eleverna för livet i dagens komplexa värld. Mitt fokus har därför varit på lärare generellt och särskilt på de didaktiska dilemman som uppstår för dem i undervisningen.

\section{Studiens dubbla syfte}

Studien syftade till att undersöka utmaningar som lärarna upplever när de arbetar med en ämnesövergripande undervisning med utgångspunkt i samhällsdilemman. I studien ville jag fördjupa några av de didaktiska dilemman som kan uppstå i sådan undervisning och detta med utgångspunkt från en svensk kontext. Genom att låta studiens svenska lärare spegla sina positioner i de positioner som övriga 
lärare i studien intog kunde vi tillsammans kritiskt granskas förgivettaganden i de svenska lärarnas praktik. Genom analys av detta kunde olika didaktiska positioners möjligheter och potentiellt negativa konsekvenser diskuteras.

Studien hade även ett syfte att föra tillbaka slutsatserna till praktiken i form av en didaktisk modell som kan stödja lärare i analys och planering av undervisning. Jag ville att de empiriska resultaten i studien skulle omformas till ett verktyg för både yrkesverksamma lärare och lärarstudenter. Med detta kan man diskutera och reflektera kring didaktiska dilemman som uppstår i denna form av undervisning. Målsättningen med den didaktiska modellen var att den skulle belysa den komplexitet som finns i sådan här undervisning. Samtidigt ska modellen erbjuda lärare stöd i att bygga upp en handlingskompetens och handlingsrepertoar för att hantera didaktiska dilemman i skolvardagen.

För att didaktisk forskning ska betraktas som potentiellt utvecklande för undervisningspraktiken menar Chaiklin (2013) att den måste innehålla tre nödvändiga aspekter. För det första behöver forskningen beskriva hur den kunskap som genererats kan relateras till den praktiska undervisningen. För det andra behöver den beskriva mer specifikt vad det är i den genererade kunskapen som kan bidra till att utveckla undervisningen. Slutligen behöver den beskriva en process för hur dessa nya kunskaper ska kunna bli en del av en förbättrad undervisningspraktik. Chaiklin menar att alla dessa delar förvisso förekommer inom forskning om undervisning, men att de alltför sällan är integrerade i varandra i en och samma studie. Denna studie har emellertid som ambition att göra detta.

\section{Licentiatuppsatsens struktur}

Studien tar sin utgångspunkt $\mathrm{i}$ att lärare $\mathrm{i}$ sin undervisning måste förhålla sig till flera olika huvudsyften där skolans uppdrag kan sägas präglas av tre skilda, men relaterade, funktioner: kvalificering, socialisation och subjektifiering (Biesta, 2009). Inom studien skapades en undervisningsmodell som stöttade de deltagande lärarna att 
arbeta med undervisning där samtliga Biestas funktioner kan få utrymme. Intentionen var att lärarna skulle arbeta med en undervisning där vetenskapliga kunskaper om komplexa och kontroversiella samhällsdilemman kompletteras med etiska dimensioner. Fokus ligger på sociopolitiska aspekter av samhällsdilemmana och undervisningen erbjuder även möjligheter för eleverna att ifrågasätta gängse strukturer och kunna ta egen ställning i frågorna (Sjöström, 2013; Sjöström \& Eilks, 2018). Denna undervisning benämns inom ramen för denna studie en reflexiv undervisning.

Med hjälp av teoretiska helhetsperspektiv i form av verksamhetsteori (Leontiev, 1978; Engeström, 1987) och "dilemmatic space" (Honig, 1994; Fransson \& Grannäs, 2013) ses undervisningen som en del av syfteskomplexa system. Läraren behöver här förhålla sig till spänningar kopplade till både formella och informella regler och rutiner för undervisningen samt även till andra aktörer i systemet. Ur dessa spänningar uppstår didaktiska dilemman i den konkreta undervisningen. I de didaktiska dilemmana positionerar sig lärarna ofta efter förgivettagna mönster. Att ta saker för givna i undervisningens komplexa vardag är en nödvändighet för läraren, men då och då måste man synliggöra och problematisera det som valts ut och tagits för givet. Detta gäller inte minst när ens undervisning förändras och utvecklas. Studiens tillvägagångssätt, att synliggöra förgivettaganden i den egna praktiken, är inspirerat av komparativ didaktik (Ligozat, Amade-Escot \& Östman, 2015). Genom att jämföra och diskutera hur den intentionellt reflexiva undervisningen utfördes i de olika kulturella kontexterna kan man spegla sina egna didaktiska val i andras och därigenom kritiskt granska sin praktik.

Med denna licentiatuppsats vill jag peka på vikten av att lärare som engagerar sig i en förändrad undervisning behöver aktivt reflektera över vilket eller vilka syften de har med sina undervisningsaktiviteter. Detta ska sedan guida beslutsfattandet i de olika didaktiska dilemman de ställs inför. Läraren behöver även vara medveten om att undervisning innehåller förgivettaganden där handlingar har rutiniserats för att hantera den komplexa skolvardagen. Alla dessa saker, som blivit rutin och automatiska, fyller en viktig funktion och 
förenklar våra vardagar. Men, när man som lärarna i denna studie ger sig in i en förhållandevis ny undervisningspraktik, med flera undervisningssyften, är det inte säkert att alla handlingar som blivit rutin i en tidigare form av undervisning längre är helt optimala. Genom att upptäcka olika förgivettagna positioner i olika didaktiska dilemmana kan man som lärare göra mer ändamålsenliga didaktiska val, i linje med det syfte man har med den aktuella undervisningsaktiviteten. I samband med diskussioner i fokusgrupper inom denna studie blev deltagare medvetandegjorda av egna förgivettaganden genom speglingen i de andra lärarnas positioner.

I licentiatuppsatsen redogör jag för en första fas av studien där beskrivningar sammanställs över hur de olika lärargrupperna agerade och resonerade kring olika delar av den reflexiva undervisningen. Här beskrivs de olika spänningar lärarna upplevde samt de didaktiska val de gjorde i de mer konkreta didaktiska dilemman som uppstod ur spänningarna. Detta bildar en grund för en andra fas av studien där fokus låg på att spegla de svenska deltagarnas positioner $\mathrm{i}$ några utvalda didaktiska dilemman i de positioner som deltagarna från de andra länderna intog. Genom komparationer i fokusgrupp kunde olika förgivettagna handlingar och val synliggöras och diskuteras. Dessa resultat visar på potentiella möjligheter och konsekvenser av olika positioner och även hur positioner i olika didaktiska dilemman relaterar till varandra. Resultaten visar även att konflikter mellan olika syften kan uppstå i undervisningen när förgivettagna positioner intas.

Resultaten från den andra fasen ligger i sin tur som grund för studiens tredje och avslutande fas som kan kopplas till att studien även hade ett syfte att föra resultaten tillbaka till praktiken. Resultaten från studien omvandlas till en didaktisk modell i form av ett diskussions- och reflektionsverktyg kring didaktiska dilemman som läraren kan ställas inför i samband med reflexiv undervisning. Detta verktyg avser att uppmärksamma lärare på både potentiella möjligheter och negativa konsekvenser med olika positioner man kan inta i olika didaktiska dilemman samt att bidra till att man ifrågasätter förgivettaganden i sin egen praktik. Tanken är att det ska stödja lärare till 
att utveckla sin handlingskompetens genom att bygga upp en bredare repertoar av handlingsalternativ i olika didaktiska situationer. 


\section{REFLEXIV UNDERVISNING MED UT- GÅNGSPUNKT I SAMHÄLLSDILEM- MAN}

Denna studie är en problemdriven form av forskning som tar sin utgångspunkt i konkreta problem som finns i vardagen och som använder teori och tidigare forskning för att förstå dessa problem. För att en läsare ska få utbyte av denna text är det essentiellt att denne har en viss orientering kring problemområdet. Detta kapitels funktion är således att sätta in läsaren i det specifika sammanhanget, och licentiatuppsatsen börjar därför med att beskriva den undervisning som studerades och vilka utmaningar som finns i denna. I detta kapitel beskrivs innehåll och bakgrund till det som benämns som reflexiv undervisning i uppsatsen. Det var när lärarna arbetade med denna form av undervisning som de upplevde olika spänningar. Som följd av dessa spänningar ställdes de inför konkreta didaktiska dilemman i planering, utförande och utvärdering av undervisningen.

\section{Reflexivitet och reflexiv undervisning}

Det som benämns som reflexiv undervisning ska inte betraktas som en ny form av undervisning kring komplexa och kontroversiella samhällsfrågor. Den reflexiva undervisningen är en syfteskomplex undervisning där eleverna förutom att lära sig mer om aktuella och kontroversiella frågor även ska få tillfälle att utveckla sina förmågor beträffande kritiskt tänkande. Dessutom ska det finnas möjlighet för eleverna att ta egen ställning i frågorna vilken de ska utveckla i diskussioner med andra elever. Undervisningen tar sin utgångspunkt $\mathrm{i}$ samhällsfrågor där alternativen ligger på en sociopolitisk nivå. Dessa är komplexa och kontroversiella samhällsfrågor där inga enkla lösningar finns. Samhällsfrågor med en tydlig dilemmakaraktär, där har alla alternativ med potentiellt negativa konsekvenser för någon 
intressent, valdes medvetet ut. Denna typ av samhällsfrågor benämns i uppsatsen som samhällsdilemman.

Undervisningen bedrivs ämnesövergripande där lärare med olika ämneskompetenser samarbetar och erbjuder eleverna möjlighet att kritiskt granska frågorna ur olika perspektiv. I undervisningsmodeller från olika ämnesfält finns de teoretiska grunder som bygger upp den reflexiva undervisningen. Men i och med att den ämnesövergripande ansatsen, avgränsningen specifikt mot samhällsdilemman på en sociopolitisk nivå och att den hade flera syften hittades ingen undervisningsmodell som entydigt kunde ringa in detta. Undervisningen i studien benämns härmed inte efter en specifik forskningsbaserad undervisningsmodell, men modellen är grundad i flera av dessa.

Begreppet reflexivitet har flera sammankopplade betydelser: beskrivande, metodologiskt och kunskapsteoretiskt (Nationalencyklopedin). Det kan kopplas samman med att individer i det moderna samhället behöver ta allt större eget ansvar, vilket i sig leder till ökad självmedvetenhet beträffande de egna sociala villkoren och den egna platsen i tillvaron. Det kan även handla om att man som forskare måste inkludera sina egna föreställningar om sitt studieobjekt i sin analys. Kunskapsteoretiskt kan begreppet förknippas med att all kunskap är socialt avhängig.

Alvesson och Sköldberg (2009) definierar ur ett metodologiskt perspektiv reflexivitet som att man på ett noggrant och systematiskt vis kritiskt granskar sina egna uppfattningar och idéer och relaterar dessa till alternativa sätt att uppfatta verkligheten. På så vis kan reflexivitet ses som motsatsen till reflexmässighet. Samtidigt är det något som är djupare än reflektion eftersom man även försöker tolka sin egen tolkning och sina egna föreställningar, vilka ligger bakom ens handlingar och beslut. Beck, Giddens och Lash (1994) förklarar att människorna i ett reflexivt samhälle har insett att de kan påverka och förändra traditionella samhällsinstitutioner med hjälp av ökad kunskap och nya innovationer. Samtidigt som detta nya samhälle öppnar upp möjligheter för förändring pekar Giddens (1990) på att 
ett reflexivt samhälle är ett risksamhälle där sociala relationer eller samhällets organisationer inte längre kan tas för givna. De institutioner som ska hantera och kontrollera de människoskapade riskerna i samhället förmår inte alltid längre att göra detta, utan kan istället riskera att börja förnekar riskerna. I detta samhälle behöver medborgaren kritiskt ganska ny information och nya förhållanden. Man behöver både kunna se frågan från andras perspektiv och reflektera över sin egen roll i förhållande till samhällsfrågor på lokal, nationell och global nivå för att kunna ta självständiga beslut och även ta konsekvenserna för dessa (Jonasson Ring, 2015).

Förutom att studiens deltagare ska utveckla elevernas reflexivitet i arbetet med olika samhällsdilemman behöver deltagarna även själva ha en reflexivitet för att förändra den egna undervisningen och reflektera över undervisningens förgivettagna rutiner. I litteraturen understryks behovet av reflexivitet inom utbildningen och det görs på olika vis utifrån de olika betydelserna av begreppet. Exempelvis beskriver Garnett och Vanderlinden (2011) en reflexiv pedagogik med inriktning mot lärares metodologiska reflexivitet att utveckla sin egen undervisning, medan Dyke $(1997,2009)$ argumenterar för att ett reflexivt lärande är centralt för både ekonomisk, social och hållbar utveckling i det senmoderna samhället. Dyke (2009) lägger fram ett ramverk för det reflexiva lärandet där detta är holistiskt och elevcentrerat samt sker i en undervisning som består av fyra huvudkomponenter. I denna undervisning uppmuntras eleverna att kunna saker, reflektera över dessa, öva och använda sina kunskaper samt att göra detta genom att interagera med andra. De fyra komponenterna överlappar varandra delvis och Dyke skriver att det inte finns föreskrivet i vilken ordning dessa ska tas upp i undervisningen.

Det som i denna uppsats benämns som reflexiv undervisning är en holistisk undervisning där eleverna ska vara aktiva och där alla Dykes (2009) fyra komponenter ska finnas med. Att öppna upp möjligheter för att elever ska kunna ifrågasätta givna strukturer och kunna ta egen ställning är en viktig del i den reflexiva undervisningen. För den skull behöver detta inte innebära att man behöver 
göra avkall på att eleverna ska få relevanta ämneskunskaper, få kunskaper kring andra aspekter av samhällsdilemmat eller för den delen utveckla andra förmågor i undervisningen. Biesta (2012a) betonar att bildning inte kan ses som en form av socialisering där man bara övertar givna kulturella och sociala sätt att tänka. Bildning, menar han, är en reflexiv process där individen både lär känna de gällande kulturella och sociala normerna och intar ett kritiskt förhållningssätt gentemot dessa. Den reflexiva undervisningen innehåller alltså flera komponenter och har flera syften vilket innebär en utmaning för en lärare.

Det kan påpekas att intentionen med undervisningen inom studien var att den skulle vara reflexiv i enlighet med ovanstående beskrivning. I den praktiskt genomförda undervisningen innebar syfteskomplexiteten emellertid att den inte alltid var det. Det som framöver i uppsatsen beskrivs som skolornas reflexiva undervisning är egentligen skolornas intentionellt reflexiva undervisning. Att den genomförda undervisningen skiljde sig åt mellan skolorna var emellertid helt i linje med studiens avsikt att just undersöka och jämföra de utmaningar som lärare ställs inför med denna typ av undervisning.

\section{Samhällsdilemman i undervisningen}

Huddleston och Rowe (2015) beskriver att komplexa och kontroversiella samhällsfrågor är frågor som väcker starka känslor och skapar spänningar i samhället då frågan i de allra flesta fall innehåller värderingar och etiska resonemang. Breiting, Hedegaard, Mogensen, Nielsen och Schnack (2009) påpekar att det finns tre nivåer av intressekonflikter som uppstår i ett samhälle. Det är dels på ett individuellt plan där oförenliga personliga behov och önskemål kan hamna i konflikt med varandra. Det är vidare en nivå där samhällsfrågan handlar om konflikter mellan individer eller grupper av individer som har motsatta intressen i en fråga. Den tredje nivån är en sociopolitisk nivå där politiska beslut som reglerar samhället kan innebära fördelar eller nackdelar för både olika grupper i samhället och för natur och miljö. 
I den reflexiva undervisningen gjordes en avgränsning mot komplexa och kontroversiella samhällsfrågor på den sociopolitiska nivån, där samhällsfrågor med en tydlig dilemmakaraktär valdes ut. Eftersom dessa samhällsdilemman är komplexa ryms innehåll från flera skolämnen i dem. Man kan finna undervisning där man arbetar med utgångspunkt i samhällsdilemman såväl i naturvetenskapliga och samhällsvetenskapliga klassrum, som inom hållbarhetutbildningen. Även inom det svenska teknikämnet lyfts detta upp och grundskolans läroplan utlovar att eleverna ska få möjlighet att utveckla sina förmågor att värdera de konsekvenser olika teknikval har för individen, samhället och miljön.

I flera avseenden liknar den praktiska undervisningen utifrån samhällsdilemman i olika ämnen och forskningen om detta varandra. I en ämnesuppdelad undervisning kan emellertid undervisningen $\mathrm{i}$ dessa olika sammanhang samtidigt skilja sig en del åt eftersom man utgår ifrån olika saker. När samhällsdilemman tas upp i ett naturvetenskapligt klassrum utgår man från hur aktuell naturvetenskap hänger samman med samhället, moral och etik. I samhällsundervisningen är det framförallt frågans sociopolitiska innehåll som sätts i centrum, medan det inom hållbarhetsutbildning är ett ämnesövergripande fokus där samhällsdilemmats ekologiska, ekonomiska och sociala dimensioner ska vägas samman. Även om det kan finnas skillnader menar Ljunggren, Unemar Öst och Englund (2015) att gränsen mellan vetenskapligt och politiskt laddade konflikter ofta kan vara diffus, vilket gör att de olika utgångspunkterna för undervisningen flyter samman. Genom en ansats till undervisning orienterad mot eko-reflexiv bildning och Vision III (Sjöström m.fl., 2016; Sjöström m.fl., 2017; Sjöström \& Eilks, 2018) kan man dock hitta en fruktbar kombination för en mer ämnesövergripande undervisning.

Sjöström, Eilks och Zuin (2016) problematiserar det neo-liberala risksamhället vi lever i ur ett utbildningsperspektiv med fokus på undervisningen i naturvetenskap. En hel del av tankarna kan även appliceras på andra ämnen. De använder termen eko-reflexiv för att beskriva och skapa förståelse för komplexiteten av att leva i världen 
och i ett risksamhälle, där vi både individuellt och kollektivt måste ansvara för att skapa socioekonomisk rättvisa och global hållbarhet. Bildningsbegreppet har sitt ursprung i tyskans Bildung och i detta sammanhang åsyftas en kritisk-reflexiv bildning (Sjöström m.fl., 2017; Sjöström \& Eilks, 2018). I en bildningsorienterad naturvetenskaplig undervisning vävs etiska och politiska dimensioner in och fokus ligger på metaperspektiv och sociopolitiska aspekter på naturvetenskapens roll i det senmoderna risksamhället (Sjöström, 2013; Sjöström m.fl., 2016).

Med eko-reflexiv bildning som utbildningsfilosofi (Sjöström, 2018) hamnar mer fokus på subjektifiering och emancipation av elever i undervisningen. Det blir en mer visionär variant av Vision II, som Sjöström och Eilks (2018) benämner som Vision III, en naturvetenskaplig undervisning för förändring av såväl individerna som samhället. De illustrerar komplexiteten i bildningsorienterad och ekoreflexiv naturvetenskaplig undervisning med figur 1.

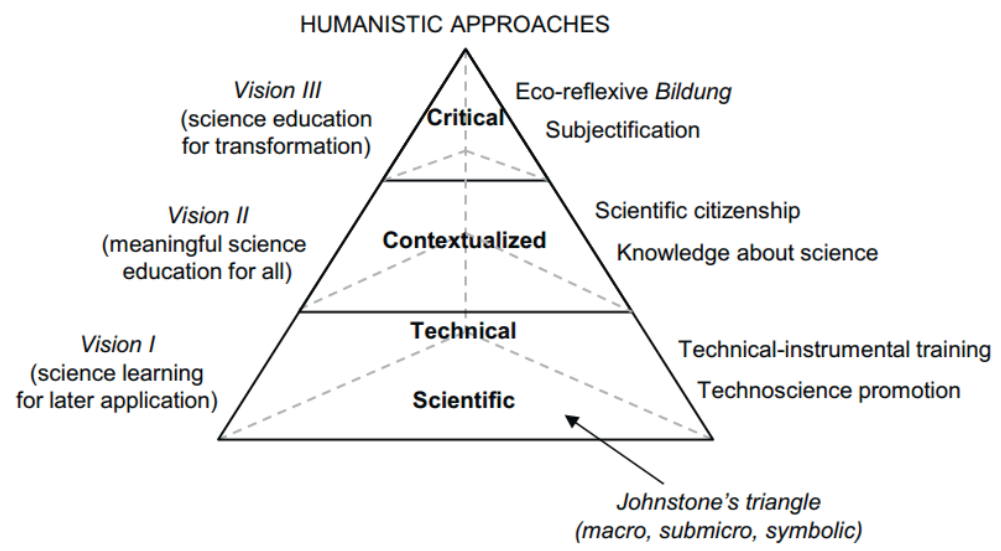

Figur 1. Tre nivåer av humanistisk naturvetenskaplig undervisning. (Sjöström \& Eilks, 2018).

De två nedersta nivåerna bygger på Roberts (2007) två visioner, medan toppen av tetraedern beskriver Vision III. Denna nivå bygger vidare på de underliggande nivåerna och inkluderar även kritiska 
aspekter som syftar till filosofisk reflektion och sociopolitiska handlingar (Sjöström, 2013). En naturvetenskaplig undervisning förankrad i eko-reflexiv bildning och Vision III strävar efter att både elever och lärare ska få en holistisk, etisk och politisk hållning rörande naturvetenskapens relation till människa, miljö, teknik och samhälle (Sjöström m.fl., 2016). En konsekvens av detta blir att ämnesundervisningen måste öppna upp sig mot att ta in externa aktörer och orientera sig mer mot ämnesövergripande perspektiv. Det skulle kunna skapa djupgående lärande för hållbarhet, samtidigt som sådan undervisning skulle vara svårorganiserad då det även behövs beslut på policynivån för att förverkliga den. Förändring av undervisningen behöver dock genomföras balanserat för att inte riskera att marginalisera den kvalificeringsfunktion som finns i en mer ämnesinriktad undervisning, då också denna funktion är relevant för undervisningen (Stuckey, Hofstein, Mamlok-Naaman, \& Eilks, 2013).

Den dominerande modellen för att arbeta utifrån samhällsdilemman i NO-undervisning benämns oftast på svenska som Samhällsfrågor med naturvetenskapligt innehåll (SNI) och motsvaras i engelskspråkiga litteraturen av Socioscientific issues (SSI). Det är samhällsfrågor med en naturvetenskaplig bas och frågor som har en viktig betydelse för både samhället och individer, och som innehåller även etiska och moraliska dimensioner (se t. ex. Ratcliffe \& Grace, 2003; Zeidler, Sadler, Simmons, \& Howes, 2005; Chang Rundgren \& Rundgren, 2010; Ekborg m.fl., 2012; Eilks, 2015). När man initialt närmar sig undervisning som kopplar in samhällsfrågor i det naturvetenskapliga klassrummet kan det ses som en enhetlig arbetsmodell. Även om undervisningen har samma ursprung visar dock Pedretti och Nazir (2011) att det finns flera olika varianter på undervisning inom detta fält.

Exempelvis har Simonneaux (2014a) visat att det finns en stor spännvidd mellan olika typer av SNI-undervisning. Hon beskriver ett kontinuum från "kall" SNI till "het" SNI (se figur 2), där en kall SNI-undervisning kyler ner det kontroversiella i samhällsdilemmat och det naturvetenskapliga och tekniska innehållet lyfts fram. Detta 
är en undervisning som egentligen inte är i linje med grundtanken med SNI, men detta starka fokus på ämnesinnehållet är en tolkning av SNI som förefaller vara vanlig i praktiken (Tidemand \& Nielsen, 2017). På vägen mot den heta änden av kontinuumet läggs dels mer tonvikt på kunskaper om naturvetenskapens karaktär, dels på utveckling av elevernas procedurkunskaper kring att resonera, argumentera och diskutera kring samhällsdilemman. Genom att eleverna därmed även tränas i att identifiera intressekonflikter och risker och väver in aspekter från andra skolämnen liksom filosofiska och politiska perspektiv närmar man sig den heta änden av kontinuumet. I sådan SNI-undervisning utvecklar eleverna ett kritiskt tänkande och ges möjlighet till att ta egen ställning. Därmed kan de utvecklas till aktiva och engagerade samhällsmedborgare (Simonneaux, 2014b).

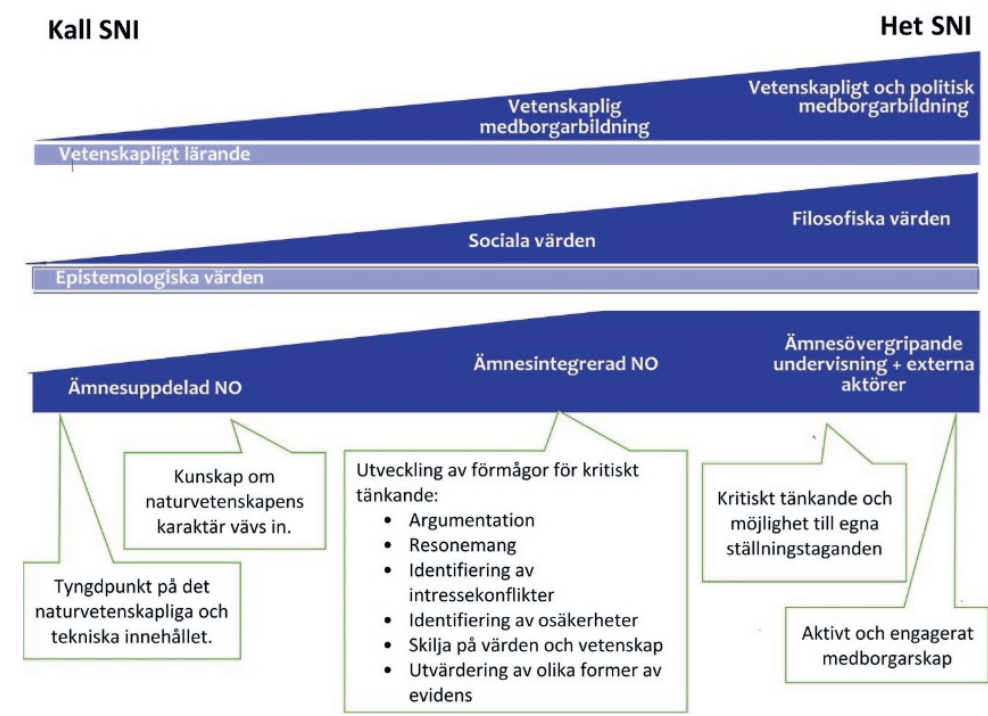

Figur 2. Olika former av SNI-undervisning. (Efter Simonneaux, 2014a)

I en litteraturöversikt ger Ottander (2015) exempel på utmaningar med SNI. I diskussioner finns en risk att naturvetenskapen försvinner när eleverna mer använder etiska resonemang och egna erfarenheter, speciellt om de har friare tyglar i sina diskussioner. Samtidigt 
finns det argument för att för stort fokus på det naturvetenskapliga innehållet tränger undan miljömässiga och sociopolitiska aspekter av samhällsdilemmat (Jensen \& Schnack, 2006; Osborne \& Dillon, 2008). I arbete med SNI ska eleverna ta till sig tillgänglig naturvetenskaplig information, men Nielsen (2012a) menar att elevernas svar inte enbart kommer från rationella vetenskapliga resonemang, utan de kommer alltid vara starkt influerade av personens ideologiska och etiska synsätt och egna erfarenheter och principer. När eleverna blandar värdeargument och kunskapsargument, vilka dessutom ofta kan vara av ekonomisk eller social art, skapas utmaningar i betygsbedömning för läraren i naturvetenskapliga ämnen (Nielsen, 2012b; Eriksson, 2014). Lägger läraren ett alltför starkt fokus på bedömning av elevernas användning av naturvetenskapliga argument kan det innebära att eleverna överbetonar dessa och frågans etiska, politiska, ekonomiska och sociala aspekter tonas ner i nvundervisningen. Det innebär att elevernas möjlighet att ta egen ställning till frågan begränsas.

I en het SNI-undervisning kan läraren behöva hantera starka känslor, en förändrad lärarroll och bedömningstveksamheter. För att klara detta behöver läraren vara medveten om både fördelar och nackdelar med de olika didaktiska alternativ som finns. Saknas denna medvetenhet kan läraren hamna i oväntade och jobbiga situationer, vilket i sin tur kan göra att läraren kan välja bort denna form av undervisning i framtiden. Att lärare ges tid och möjlighet att i sin praktik reflektera över vilka syften som undervisningen har och analysera för- och nackdelar med olika undervisningsstrategier måste därför anses som mycket viktigt.

Inom forskning kring SO-undervisning med relevans för denna studie finns forskningsfältet Citizenship Education (CE). I linje med den variation som finns mellan de olika länderna kring de samhällsorienterande ämnena vad gäller innehåll och betoning, finns det också olika betoning i vad CE egentligen innebär. Kerr (2000) skiljer på en mer passiv medborgarutbildning som är mer historisk och beskrivande och en mer aktiv och kritisk medborgarutbildning som är mer 
sociopolitisk och rättviseorienterad. I en forskningsöversikt identifierar Olsson (2016) tre traditioner inom denna undervisning, vilka känns igen i Biestas (2009) tre funktioner för utbildning, nämligen en mer socialiserande tradition, en mer vetenskapligt och ämnesinriktad tradition samt traditionen Reflective Inquiry. Den senare riktas in mer på att utveckla eleverna till medborgliga beslutsfattare och att utveckla deras kritiska tänkande genom ämnesövergripande arbetsformer kring kontroversiella samhällsproblem. Olsson beskriver hur olika varianter av dessa kategorier presenterats och i debatten mellan betydande forskare inom fältet har ofta de olika traditionerna beskrivits som separerade från varandra och konkurrerande. När man fördjupar vad dessa forskare egentligen säger visar det sig enligt Olsson att traditionerna överlappar varandra. Hans egen studie visar på att även lärare i undervisningspraktiken som regel kombinerar olika traditioner och kombinerar kunskapsmål med mer fostrande mål i undervisningen.

Enligt Crick (1998) bör CE betona konflikt- och kontroversperspektiv och samhällsfrågor betraktas som dilemman, både ur kunskapsmässiga och politiska perspektiv. Ljunggren och Unemar Öst (2010) visar att de svenska läroplanerna i modern tid alltid betonat medborgarnas deltagande i politiskt beslutsfattande. Detta öppnar upp för en mer kritisk medborgarutbildning, där skolan förväntas utveckla medborgarna till politiska aktörer som kan delta i diskussioner och fatta beslut i samhällsfrågor. Samtidigt påpekar Ljunggren och Unemar Öst att lärarna ställs inför ett dilemma. De ska dels bedriva en undervisning som är normerande och socialisera eleverna och förmedla samhällets gällande sociala, politiska och kulturella värderingar, dels öppna upp för olikheter i politiska och moraliska värderingar. Både internationell och nationell forskning visar att lärare i lägre grad prioriterar en undervisning där elever med avvikande åsikter ges möjlighet att diskutera kring olika samhällsdilemman (Ljunggren \& Unemar Öst, 2011).

Inom en kritisk CE är analys och diskussioner av samhällsdilemman en viktig del, och en benämning som används inom SO-undervisning 
på dessa samhällsfrågor är kontroversiella frågor. Detta har en bakgrund i det som sedan 1970-talet internationellt benämnts som controversial issues education (Ljunggren m.fl., 2015). Enligt Ljunggren m.fl. är det samhällsfrågor där det inte finns några självskrivna svar, men där det samtidigt finns olika och starka uppfattningar om ämnet. Det kan även finnas olika åsikter i vilken grad det är ett problem överhuvudtaget. Det finns även en sociopolitisk relevans i frågan där olika gruppers åsikter står mot varandra. Kontroversiella frågor är samhällsdilemman där det inte bara finns kunskapsmässigt baserade motsättningar. Det finns även en politisk dimension där motsättningar grundas i deltagarnas normer, insikter, ståndpunkter, kulturella vanor och andra erfarenheter. Att arbeta med kontroversiella frågor i SO-undervisningen skapar enligt Ljunggren m.fl. en undervisning där politiska och moraliska ställningstaganden av eleverna ses som lika viktigt som formellt kunnande inom dessa ämnesområden.

Ljunggren m.fl. (2015) pekar på att i undervisning med kontroversiella frågor behöver lärarna göra en rad didaktiska val. Det kan gälla i vilken utsträckning diskussionerna främst ska betona lärande av explicita kunskaper om ämnet och problemet, om det ska utveckla förmågor kring kritiskt tänkande eller om det främst syftar till att eleverna ska uppleva ett sociopolitiskt deltagande. Ljunggren (2008) beskriver två olika principer för hur man kan hantera politiska frågor i undervisningen och han benämner dem epistemologiprincipen och det offentliga rummets princip. Han menar att dessa två principer inte ska ses som varandras motsatser utan snarare som olika didaktiska strategier som var och en har olika syfte och mål. De ska ses som komplement till varandra och det viktiga är att inte endera principen används ensidigt.

Epistemologiprincipen karakteriseras av en undervisning som primärt förbereder eleverna för ett framtida politiskt deltagande genom att utveckla generella politiska kunskaper och förmågor. Följer man istället det offentliga rummets princip handlar undervisningen om att "här och nu" diskutera politiska frågor där eleverna ska ges utrymme att ta egen ställning i frågan, om än tillfälligt. Tryggvason 
(2015) skriver att i elevdiskussioner utifrån epistemologiprincipen är det inte så viktigt vad eleverna tycker i den kontroversiella frågan utan det primära är de kommit fram till ett svar genom en rationell argumentation och med ett väl underbyggt resonemang. En fråga ses som ett medel för att stärka elevernas förmågor såsom att tänka kritiskt och att argumentera. Utifrån det offentliga rummets princip påpekar Tryggvason att det istället är vad eleverna svarar som är viktigast. Själva frågan i sig ställs alltså i förgrunden.

Hållbarhetsutbildning och dess undervisning och lärande strävar efter att eleverna ska utveckla både förmåga och vilja att verka för hållbar utveckling lokalt och globalt. I detta ska eleverna kunna se hållbarhetsfrågor utifrån både ekonomiska, sociala och miljömässiga perspektiv (SOU, 2004). Även om inte undervisning med utgångspunkt i samhällsdilemman inrymmer alla aspekter av hållbarhetsutbildning, är denna undervisning icke desto mindre en viktig del av hållbarhetsutbildningen i skolan. Traditionellt handlade hållbarhetsutbildning om en faktabaserad undervisning och sedermera även en normerande undervisning, men inom dagens hållbarhetsutbildning betonas även osäkerhet, intressekonflikter och komplexitet i de hållbarhetsfrågor som finns i dagens samhälle (Öhman, 2003; Ottander, 2015). Hållbarhetsutbildning präglas av en ämnesövergripande undervisning som baseras på olika pedagogiska metoder och denna syftar till att utveckla handlingskompetens hos eleverna för att de ska kunna hantera framtidens utmaningar. I en svensk kontext har mycket fokus hamnat på diskussioner där pluralism kan ses som en demokratisk process där hållbarhetsfrågor ständigt omförhandlas i möten mellan individer (Lundegård, 2007). Att arbeta med samhällsdilemman inom hållbarhetsutbildning handlar om att låta eleverna diskutera hållbarhetsfrågor och förstå, värdera och formulera argument för att kunna pröva egna och välgrundade ställningstaganden (Englund, Öhman, \& Östman, 2008).

Kopnina (2012) menar att i en undervisning där alltför mycket tonvikt läggs på att eleverna ska få forma egna åsikter och ta ställning finns en risk att hållbarhetsutbildningens miljöperspektiv hamnar i bakgrunden till förmån för de sociala och ekonomiska perspektiven. 
En annan utmaning inom hållbarhetsundervisningen är att balansera ambitionen att ge eleverna handlingskraft för att verka för hållbar utveckling både lokalt och globalt. Om för stort fokus läggs på att eleverna själva ska vara aktiva och vara de som löser hållbarhetsfrågorna genom egna handlingar, skapar det en stark individualisering av miljöproblemen. Ideland \& Malmberg (2015) pekar på risken att eleverna skuldbeläggs kring hållbarhetsfrågor där lösningen på problemet egentligen finns på en politisk nivå. Hasslöf (2015) visar på den komplexitet som finns i undervisningen kring hållbarhetsfrågor och att ett avgörande begrepp som kritiskt tänkande kan få olika kvalitativa innebörder i olika undervisningssituationer. Hasslöf visar att lärare ser kritiskt tänkande både som att eleverna är självständiga och ifrågasättande, men också som att elever resonerar utifrån naturvetenskapliga rationella kunskaper. Det blir en paradox där eleverna uppmanas att ifrågasätta saker och ting samtidigt som de förväntas argumentera med det som skolan lärt dem i form av ämneskunskaper.

Även inom teknikdidaktiken är undervisning utifrån samhällsdilemman central. Keirl (2012) menar att olika former av teknik bör betraktas som kontroversiella förslag i vilka det finns en inbyggd osäkerhet kring teknikens konsekvenser för människa, miljö, samhälle, etik, lagar och politik. Pavlova (2013) förespråkar en mer kritisk och transformativ teknikundervisning där hållbar utveckling inte endast behandlas ur ett ekologiskt perspektiv med fokus på ekologiskt hållbar design, utan även där sociala och ekonomiska aspekterna bör vägas in. Hon påpekar att teknikundervisningen kan bidra till att utveckla elever till ansvarstagande världsmedborgare som har förutsättningar att i framtiden hantera de potentiella socioekologiska kriser som dagens samhälle skapar (Pavlova, 2015), genom att tekniska lösningar kontextualiseras och relateras till olika länders ekonomiska och sociala förutsättningar.

Undervisningen med utgångspunkt i samhällsdilemman benämns alltså på olika sätt i olika ämnesfält. När man tittar på het SNI, kontroversiella frågor i samhällsundervisning, hållbarhetsfrågor inom hållbarhetsutbildningen samt teknik som kontroversiella förslag 
inom teknikundervisningen sammanfaller en hel del. I en undervisning med utgångspunkt i samhällsdilemman kan läraren lägga betoningen på olika delar och i denna komplexa form av undervisning ställs läraren inför flera didaktiska val. Detta gör att det blir en variation i den praktiska undervisningen vilket illustreras av kontinuumet som Simonneaux (2014a) ställer upp där det går från en kall SNI med stort ämnesfokus till en het SNI-undervisning. I denna heta SNI ges även utrymme för andra perspektiv än de ämnesmässiga, kritiskt tänkande utvecklas och aktivism uppmanas. Min studie ville undersöka de utmaningar lärare stöter på i en ämnesövergripande undervisning i linje med Sjöström och Eilks (2018) bildningsorienterade och eko-reflexiva undervisning. Detta är en undervisning i den heta delen av SNI-kontinuumet. I denna uppsats benämns den alltså reflexiv undervisning. 


\section{SYFTESKOMPLEXITET OCH DIDAK- TISKA DILEMMAN}

Det som jag presenterar i denna licentiatuppsats skulle kunna uttryckas som "banal forskning". Med detta lätt självironiska uttryck avses en forskning som tar sin utgångspunkt i till synes enkla och banala frågeställningar i den vardagliga undervisningspraktiken. När man undersöker dessa visar de sig att det är betydligt mer komplexa än vad det först verkade. För att hantera dessa, vid första anblicken, banala utmaningar i vardagen krävs genomtänkta strategier. I detta kapitel presenterar jag teori kring den syfteskomplexitet som finns i en reflexiv undervisning. Jag beskriver även de holistiska teoretiska perspektiv som hjälpte till att orientera mig i denna komplexitet och att både upptäcka och analysera spänningar och didaktiska dilemman. Slutligen redogör jag för teoretiska utgångspunkter för hur man kan skapa didaktiska modeller, vilka kan vara hjälpsamma redskap för lärare att utveckla sin undervisning.

\section{Utbildningens tre huvudsyften}

Ett grundläggande uppdrag för skolan är att förbereda eleverna för framtiden, men då det råder en inbyggd osäkerhet kring vad som är viktigt för eleverna att ha med sig från skolan in i framtiden är detta uppdrag inte helt okomplicerat. För att hantera den osäkerhet som finns utgår Biesta (2009) ifrån att utbildningssystemet syftar till att utföra tre olika funktioner. Dessa huvudsyften är inte separerade från varandra utan relaterar till, och överlappar, varandra. Biesta benämner dessa kvalificering, socialisering och subjektifiering. Han skriver att kvalificering handlar om att eleverna ges kunskaper och färdigheter som de behöver för framtida arbete eller för den delen $i$ andra delar av livet. Socialisering handlar om att skolan ska överföra värderingar, traditioner, färdigheter och kunskaper till eleverna så 
att de kan fungera i samhället beträffande sociala, politiska och kulturella ordningar.

Biesta $(2009,2011)$ hävdar att dagens skola lägger alltför stor vikt vid just kvalificering och socialisering. Han förespråkar att skolan inte bara bör återge en fördefinierad mall av vad "goda medborgare" är för något. Eleverna ska även ges möjlighet att utvecklas till självständiga och ansvarstagande individer som deltar i samhällets utveckling och förändring. Biesta kallar denna funktion för subjektifiering och han menar att denna funktion kan förstås som något av en motsats till socialisation. Enligt Biesta (2012a) är subjektifiering en reflexiv bildningsprocess som sker i relation till kvalificering och socialisering. Individen bygger upp både ett förhållande till och en kritisk hållning mot det existerande samhället med gällande sociala, etiska och politiska ordningar. Individerna blir autonoma med både kapacitet att utföra handlingar i samhället, men även med kapacitet att ta ansvar (Biesta, 2012b).

Man kan se bildning som en kritisk-reflexiv process där man etablerar ett förhållande till sin kultur och sitt samhälle samtidigt som man förhåller sig kritisk i relation till dessa (Sjöström, under utgivning). Med detta synsätt hamnar begreppen kritisk-reflexiv bildning (Sjöström m.fl., 2017; Sjöström \& Eilks, 2018) och subjektifiering (Biesta, 2009) nära varandra, även om bildningsbegreppet även inkluderar socialisering. Enligt Uljens (2014) innebär bildningsprocessen att individen utvecklar både en kulturell tillhörighet och en personlig unikhet. I bildning förenas alltså socialisation med subjektifiering.

Subjektifiering handlar inte om att lära ut ett förutbestämt kunskapsinnehåll eller specificerade förmågor utan istället om att skapa utrymme i undervisningen för eleverna att utmana gällande synsätt, ge dem möjlighet att undersöka sin egen hållning kring en frågeställning och vidare att ta egen ställning (Hasslöf \& Malmberg, 2015). Skolans undervisning kan bara skapa utrymme för subjektifiering; man kan aldrig se detta som ett förväntat resultat av en bestämd läraktivitet. Läraren kan emellertid organisera undervisning med utgångspunkt från samhällsdilemman på sådant vis så att eleverna får 
möjlighet att bli politiska subjekt (Hasslöf \& Malmberg, 2015). Lundegård och Wickman (2012) definierar att vara ett politiskt subjekt som den process när en individ tar ställning i en samhällsfråga och deltar i en ömsesidig diskussion kring frågan.

Biesta (2015) framhåller att det är viktigt att diskutera vad som menas med god utbildning och inte förledas tro att det räcker med att diskutera effektiv utbildning. Effektiviteten i utbildningen refererar endast till i vilken grad som ett önskvärt resultat uppnås i undervisningen och inte till i vilken grad resultatet är önskvärt i sig. I mätningar av effektivitet hamnar fokus på utbildningens kvalificeringsfunktion där man värderar det som är mätbart, och då riskerar man missa annat som är av stort värde. Biesta menar därför att man måste lyfta blicken och fundera på vad utbildningen ska sträva mot, alltså vad som kännetecknar en god utbildning. För att få en god utbildning krävs det att lärare diskuterar frågan vad som är det egentliga syftet med utbildningen och med den undervisning de planerar, men Biesta (2009) menar att detta är något som görs i alltför liten omfattning på skolorna. Lärares beslutsfattande både i planering, genomförande och utvärdering av undervisning spelar en central roll och det behöver därför finnas utrymme för lärare att reflektera och diskutera utbildningens olika funktioner och potentiella syften och hur man arbetar i riktning mot dessa syften (Biesta, 2015).

De beslut som lärare fattar i undervisningens komplexitet är situationsberoende och därmed unika. De didaktiska val som görs måste relateras till vilket syfte läraren har med den aktuella undervisningen och kan inte fattas efter föreskriven mall uppifrån utifrån "what works"-undervisning. Biesta (2015) skriver att forskning som hävdar att viss undervisning antingen fungerar eller inte fungerar är utan värde om man inte relaterar det till vad undervisningen syftar till. Han ger exempel på forskning som hävdar att läxor inte på något signifikant sätt förbättrar elevers studieresultat, men även om det kan vara på detta vis behöver det inte betyda att man inte ska ge läxor. Är syftet relaterat till undervisningens kvalificeringsfunktion kanske läxor har ett tveksamt värde, men relaterar man istället syftet med läxorna till undervisningens subjektifieringsfunktion kan de 
istället ha ett stort värde. Om syftet med läxan är att utveckla elevens ansvarstagande att utföra uppgifter utan lärarens övervakande blick kan läxor vara ett fullt relevant inslag i undervisningen, även om dessa resultat är svåra att mäta.

För att man ska få en god utbildning behöver lärare i ett första steg göra klart för sig själv och andra inblandade vad den aktuella undervisningen syftar till, i relation till de tre huvudsyftena kvalificering, socialisering och subjektifiering (Biesta, 2015). Biesta poängterar att även om de tre huvudsyftena går in i varandra och är förutsättningar för varandra, kan de ibland stå i konflikt med varandra. Han menar därför att man som lärare i ett andra steg måste hitta en balans mellan huvudsyftena och göra avvägningar där ett eller två av huvudsyftena kan behöva tonas ner under en begränsad undervisningssekvens. Detta känns igen i Roberts (1982) diskussioner kring olika kunskapsemfaser, där han menar att man ska sätta olika emfaser i förgrunden vid olika tidpunkter i sin undervisning. Han påpekar att det dock krävs att läraren har kännedom om olika kunskapsemfaser och om att undervisningen kan ha olika syften.

I ett tredje steg behöver lärare utifrån syftet man prioriterat göra didaktiska val, både i planeringen av och i genomförandet av den konkreta undervisningen, utifrån den aktuella klassrumssituationen. Även om man har utkristalliserat ett specifikt syfte med den aktuella undervisningen behöver man också reflektera över hur ens didaktiska val påverkar de andra huvudsyftena. Något som kortsiktigt kan vara positivt sett till ett huvudsyfte kan vara negativt på lång sikt sett ur ett annat. Biesta ger som exempel att hot eller mutor skulle kunna vara positiva för elevers resultat vad gäller kvalificeringssyftet, men när det gäller de två andra huvudsyftena kan sådant agerande ha högst negativ effekt.

Biesta och Osberg (2010) betonar att undervisning kan kännetecknas av en komplexitet med olika mål- och intressekonflikter och Frelin (2013) skriver att läraryrkets komplexitet kan analyseras utifrån fyra sammanflätade aspekter. Den första benämner hon meningskomplexiteten vilket innebär att elevernas egna meningsskapanden 
inte går att kontrollera av läraren. Eleven kan, men behöver inte, lära sig det den blir undervisad om och det går därför inte att sätta likhetstecken mellan undervisning och lärande. Den andra aspekten är innehållskomplexitet och hänger samman med didaktikens Vadfråga och orsakas av att olika undervisningsinnehåll inte alltid samverkar med varandra. I en undervisning där fokus läggs på elevsocialisering exempelvis i form av elevaktiva samtal och diskussioner kan detta kollidera med kursplanernas centrala innehåll av ämneskunskaper. Detta gränsar till den tredje aspekten av komplexitet som Frelin beskriver, nämligen medelskomplexitet som kan kopplas till didaktikens Hur-fråga och handlar om de många val som läraren måste göra i undervisningen. Dessa val görs ofta utan att läraren helt kan överblicka olika konsekvenser som finns med de olika handlingsalternativen.

Den fjärde aspekten som Frelin (2013) beskriver är syfteskomplexitet och kan illustreras av den didaktiska Varför-frågan. Läraren måste hantera de olika syften som undervisningen har och använda sitt omdöme för att väga olika syften mot varandra. Vilket syfte läraren väljer att prioritera påverkar sedan lärarens val av innehåll och metoder. Frelin menar att läraryrket särskiljer sig från andra professioner som hanterar komplexa praktiker genom att man i dessa sällan behöver diskutera själva syftet. När man som lärare får motstridiga direktiv på olika nivåer i utbildningssystemet och när syftena står i strid med varandra är det en utmaning för läraren att bestämma vad som är överordnat det andra. Frelin betonar att analyser av läraryrkets komplexitet är avgörande i förändringsprocesser för att förhindra att förändringarna motverkar intentionen med förändringen.

\section{Verksamhetsteoretiska glasögon}

Verksamhetsteorin har sin grund i den sociokulturella teori som skapades av Lev Vygotskij i slutet på 1920-talet. Han gjorde detta i samarbete med Aleksei N. Leontiev som kom att utveckla den vidare i Sovjetunionen ända fram till 1970-talet. Efter det har främst Yrjö Engeströms uttolkningar av Leontiev varit framträdande i utvecklingen av verksamhetsteorin fram till våra dagar. Enligt Engeströms 
verksamhetsteori är människans lärande beroende av det kulturella och sociala sammanhang där lärandet sker, vilket i sin tur är skapat av dess historiska utveckling

\section{Leontievs verksamhetsteori}

Chaiklin (2007) diskuterar Leontievs tankar genom att beskriva en verksamhet som ett generellt fenomen där organiserade mänskliga handlingar utförs med intentioner att förverkliga ett objekt, vilket i sin tur är något som ska stilla ett samhälleligt behov. Ett objekt är föremålet för verksamheten och kan vara många saker som ett ting, en teori eller en social eller kulturell företeelse. Det är emellertid alltid något som gör att behovet som finns kan tillfredsställas. Chaiklin menar att det är avgörande för förståelse av verksamhetsteorin att en verksamhet inte ses som något som bildas kring ett behov som endast ett fåtal individer har. Istället uppstår en verksamhet när något nödvändigt för samhället saknas och inte enkom individuella mänskliga handlingar kan förverkliga objektet. En verksamhet blir det kollektiva sätt som samhället vill försöka lösa detta behov på. Grundläggande är även att verksamheter inte börjar om från början hela tiden utan att de tar sin utgångspunkt i gällande traditioner och samhällets övriga kulturhistoriska kontext.

Chaiklin (2007) förklarar vidare att ur verksamhetsteorins logik uppstår ett motiv i samspel med samhällets kollektiva behov. Motivet för verksamheten är att skapa det objekt som kan göra att behovet tillfredsställs. Motivet blir en avbild av vad verksamheten vill åstadkomma och det som verksamheten organiseras mot. Inom verksamheten utförs olika handlingar vilka är inriktade mot att skapa objektet som kan stilla det behov som finns. Behov, motiv och handlingar står i ett dynamiskt förhållande till varandra där behov kan förändras och återuppstå, varvid verksamheten reproduceras. All verksamhet behöver ha ett motiv, den syftar till att skapa någonting som samhället har behov av. Den enskilde individen, som är en del i en verksamhet, behöver inte till fullo vara medveten om verksamhetens ursprungliga motiv och objekt. Chaiklin illustrerar detta med exemplet på hur obligatorisk skolgång växte fram ur national- 
staternas behov av lojala medborgare vilka ska ha en positiv inställning till staten. Även om skolor och andra instruktioner skapades för att realisera detta objekt kan detta vanligtvis inte urskiljas i verksamhetens delar i dagens skola.

Leontiev (1978) utvecklade verksamhetsteorin genom att visa på skillnad mellan individuella handlingar och den kollektiva verksamheten samt visade på verksamheternas olika beståndsdelar. Han menar att en verksamhet endast kan studeras genom dess handlingar och operationer, men samtidigt kan dessa inte bara reduceras till detta utan måste ses gentemot hela verksamheten och dess motiv. Leontiev beskriver de tre beståndsdelar av mänsklig verksamhet som illustreras i figur 3. Verksamheten står i relation till motivet vilket ska realiseras i ett objekt, medan handlingarna, som är de som bygger upp verksamheten, står i relation till olika mål eller intentioner. För att förverkliga handlingarnas intentioner utförs olika operationerna vilka är specifika metoder med hjälp av vilka arbetet utförs. Dessa operationer utförs till stor del rutinmässigt, medvetet och omedvetet, och utförs beroende på rådande betingelser. Verksamhetens motiv och dess objekt påverkar de mål och intentioner som handlingarna genomförs efter. Dessa påverkar i sin tur även verksamhetens motiv i ett växelspel. Samtidigt står målen och intentionerna i en ömsesidig relation med de betingelserna för verksamheten vilka kan påverka och förändra hela verksamheten och dess objekt.

$\begin{array}{lcc}\text { Verksamhet } & \leftarrow \text { relation till } \rightarrow & \text { Motiv/objekt } \\ \downarrow \text { relation till } \uparrow & & \downarrow \text { relation till } \uparrow \\ \text { Handlingar } & \leftarrow \text { relation till } \rightarrow & \text { Mål/intentioner } \\ \downarrow \text { relation till } \uparrow & & \downarrow \text { relation till } \uparrow \\ \text { Operationer } & \leftarrow \text { relation till } \rightarrow & \text { Betingelser }\end{array}$

Figur 3. Verksamhetens olika beståndsdelars systematiska förhållande. (Efter Leontiev, 1978). 
Illustrationen ovan av verksamhetens beståndsdelar kan förleda en att tolka det som om verksamheten kan delas upp i statiska byggblock i form av handlingarna som i sin tur byggs upp av mindre byggblock i form av operationer, där dessa står i ett linjärt orsakverkanförhållande till varandra. Gör man detta och antar en strikt hierarkisk struktur av verksamheten, istället för att se det som ett dynamiskt system, missförstår man verksamhetsteorin (Chaiklin, 2007). Beståndsdelarna står istället i ett systemiskt förhållande till varandra där verksamheten, handlingarna och operationerna är sammanflätade. Leontiev (1978) förklarar att operationer kan ha börjat som medvetna handlingar, men med tiden har de blivit omedvetna handlingar när de gradvis utförts rutinmässigt. Han påpekar även att skillnaderna mellan handling och verksamhet ibland kan vara svåra att exakt definiera eftersom mål och motiv ofta överlappar varandra och kan tolkas på olika sätt.

När en lärare agerar i verksamheten undervisning sker detta arbete mot flera gemensamma motiv. Alnervik (2013) beskriver undervisning som multimotivdriven där det finns flera lager motiv som samhället lagt på skolan och som efter hand flätats samman och lagrats in i verksamheten, vilket över tid skapat olika system av handlingar. Inom verksamheten utförs en rad målinriktade, och ofta tidsbegränsade, handlingar, som i regel egentligen är kedjor av handlingar. Det kan vara att läraren först har en genomgång kring ett kunskapsinnehåll (en handling), följt av att läraren ger eleverna en enskild arbetsuppgift med intentionen att de ska utveckla sina kunskaper (en annan handling) och detta avslutas med att läraren och eleverna har en helklassdiskussion (en tredje handling). Alla dessa handlingar genomförs för att uppnå de mål läraren satt upp för lektionen och dessa mål är riktade mot de motiv eller syften samhället har för att arrangera skola, även om läraren inte alltid är helt medveten om motiven. Beroende på vilka mål läraren väljer att arbeta mot leder detta till olika handlingar inom lärarens undervisning, vilket man i skolvärlden beskriver som att läraren väljer olika innehåll och undervisningsmetoder (Samuelsson \& Engwall, 2008). Under lektionen utförs vidare en rad mer eller mindre omedvetna handlingar och operationer styrda av rådande förutsättningar i klassrummet, 
exempelvis i form av att läraren väljer olika förklaringsmodeller för kunskapsinnehållet, intar olika roller, fördelar talutrymme och samlar underlag för bedömning.

Holmqvist och Olander (2017) kopplar samman de tre beståndsdelar (verksamhet, handling och operation) som Leontievs beskriver med didaktikens tre grundfrågor. De drar paralleller mellan den motivstyrda undervisningsverksamheten i stort och den didaktiska syftesfrågan: Varför ska ett specifikt innehåll undervisas?. Inom en verksamhet genomförs sedan en rad målstyrda handlingar och denna beståndsdel motsvaras av den didaktiska frågeställningen: Vilket innehåll ska ingå och vilka läraktiviteter ska genomföras?. I handlingarna utförs en rad operationer vilka styrs av de rådande betingelserna i klassrummet och kopplas samman av Holmqvist och Olander med den didaktiska frågan: Hur innehållet undervisas?. I sin studie visar de att Leontievs uppdelning av en verksamhet i tre beståndsdelar kan hjälpa till att beskriva undervisningsaktiviteter. Holmqvist och Olander visar även att detta kan bidra till att uppmärksamma lärare på hur vissa didaktiska val gällande hur klassrumsundervisningen ska genomföras kan påverka hur eleverna uppnår olika lärandemål negativt.

\section{Engeströms verksamhetssystem}

Leontiev beskrev hur en verksamhet uppstår där behov, motiv och handlingar står $\mathrm{i}$ ett dynamiskt förhållande till varandra och även relationerna mellan verksamhet, handling och operation. På detta byggde Engeström (1987) vidare genom att betrakta olika former av mänsklig verksamhet som komplexa verksamhetssystem där det kan uppstå motsättningar i och mellan olika delarna av systemet. Han utvecklade därigenom Leontievs idéer om verksamhetsteori genom att skapa en modell för mänsklig verksamhet, där både individuella handlingar och kollektiva handlingar kan förstås i ett kollektivt verksamhetssystem. Medan Leontiev främst hade beskrivit hur en verksamhet kan uppstå och vilka delar och drivkrafter som den har, la Engeström fokus på hur verksamheter utvecklas och förändras (Berthén, 2007). 
För att förstå hur mänsklig verksamhet fungerar spårade Engeström och andra verksamhetsteoretiker ursprunget till människan för att beskriva vad som skiljer vår verksamhet från djurens (Engeström, 1990). Djurens beteende består typiskt av växelverkan mellan individen, naturen och de andra medlemmarna av populationen. Individens överlevnad är helt beroende av den omgivande naturen, men möjligheten att forma sin omgivning, och därmed sitt eget öde, ökar radikalt om individen interagerar med andra individer i populationen (figur 4). Detta kan urskiljas hos de utvecklade primaterna där någon form av socialt liv skapas och kollektiva handlingar kan utföras.

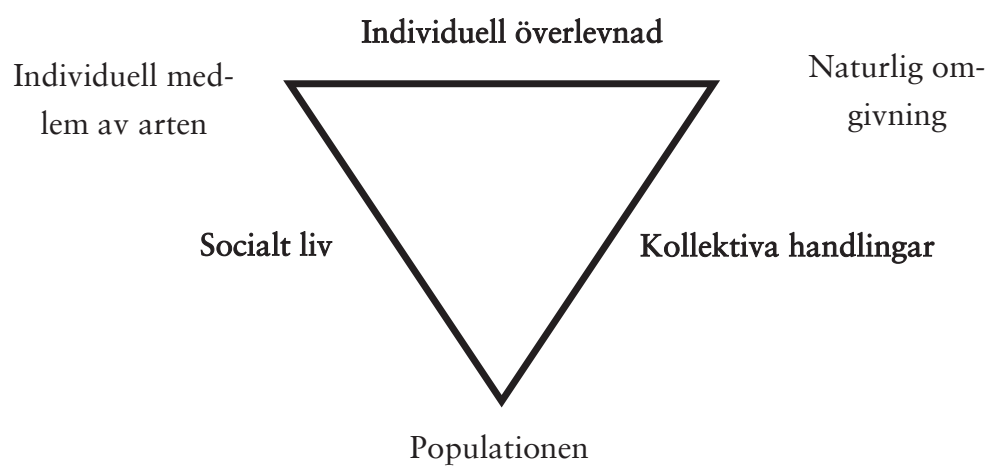

Figur 4. Den allmänna strukturen i djurens beteende. (Efter Engeström, 1990).

Även om övergångsskedet från djurliv till mänsklig verksamhet är dolt i mörker, kan man se en utveckling där man kan utöka triangeln som beskriver den allmänna strukturen i djurens beteende med tre nya trianglar (figur 5). När man på ett systematiskt vis började använda sig av olika typer verktyg och lagra produkter skapade detta helt andra möjligheter att styra och förändra omgivningen. I det sociala livet som uppstod utvecklades kollektiva traditioner och regler skapades, samtidigt som en arbetsfördelning uppstod. Ett samhälle skapades och en övergång från natur till samhälle hade oåterkalleligen skett. 


\section{Framväxande av verktygstillverkning}

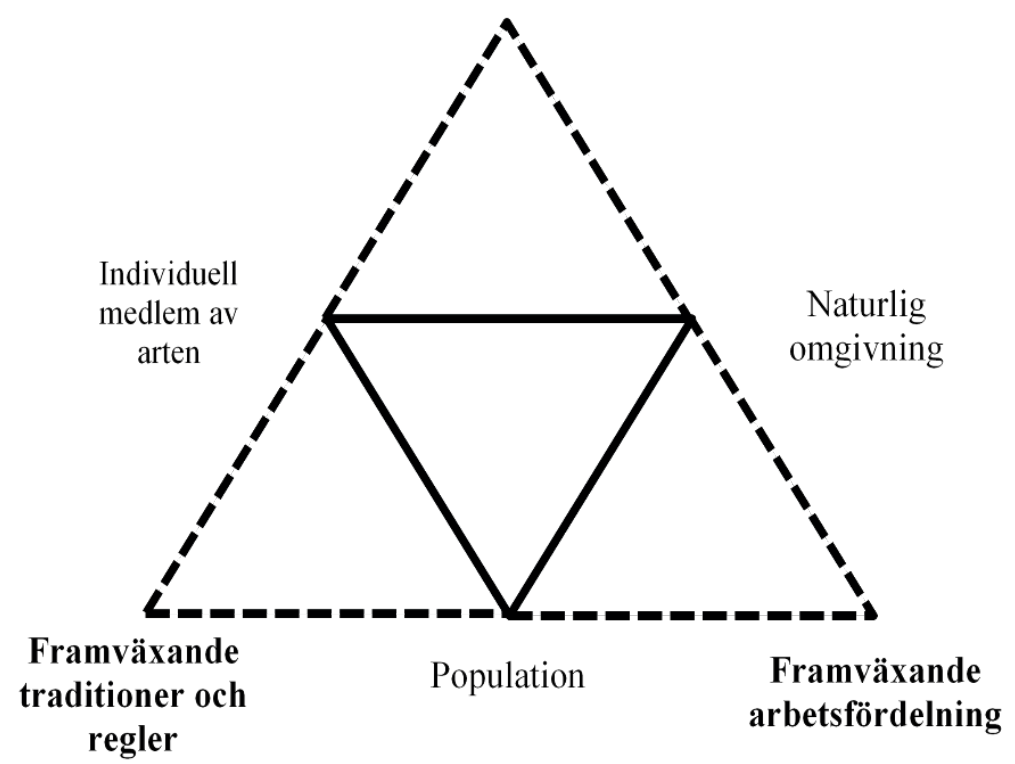

Figur 5. Övergångsfas från djurliv till mänskligt samhälle. (Efter Engeström, 1990).

Ur detta har Engeströms (1987) modell av ett verksamhetssystem växt fram bestående av sex olika noder vilka är medierande verktyg, subjekt, regler, gemenskap, arbetsfördelning, objekt och resultat (se figur 6). I den övre triangeln beskrivs samspelet mellan subjektet och verksamhetens objekt, där subjektet med hjälp av olika medierande verktyg önskar förändra objektet för att få ett specifikt resultat. Dessa verktyg kan både vara fysiska och språkliga och de hjälper oss att förstå och påverka vår omvärld. I verksamhetssystemet finns även olika regler, både explicita och implicita bestämmelser, samt normer och konventioner vilka alla påverkar deltagarnas handlande och interaktioner. Gemenskapen är andra personer som delar samma objekt och arbetsfördelningen beskriver hur arbetet fördelas inom verksamheten och denna nod innefattar även makt och status. 


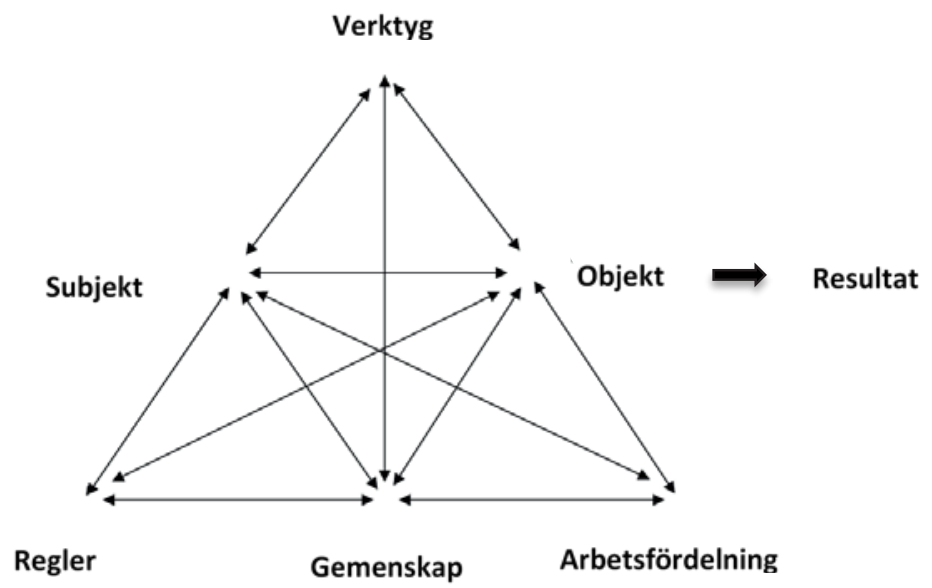

Figur 6. Modell av mänsklig verksamhet (Efter Engeström, 1987).

Det som driver förändringar i en verksamhet menar Engeström (1987) är de inneboende motsättningar som finns inom det komplexa verksamhetssystemet. Dessa motsättningar uppstår när en verksamhet ska fungera oberoende, men samtidigt är del av en större verksamhet eller har ett delvis gemensamt objekt som en närliggande verksamhet. De olika motsättningarna visas sedan i form av spänningar inom verksamheten vilka ger upphov till dilemman eller konflikter inom verksamheten. Engeström delar in motsättningar i fyra nivåer där det i den första nivån handlar om motsättningar inom verksamhetens olika noder och han skriver att det där kan uppstå motsättningar mellan bruksvärdet och bytesvärdet.

Motsättningar innebär att det finns motstridiga krav eller konsekvenser och då uppstår en spänning. Denna licentiatuppsats handlar om dessa spänningar som visar sig i ett undervisningssammanhang och försätter läraren i olika dilemmasituationer. Det handlar exempelvis om en spänning för läraren där den ska lägga tid på att utveckla eleverna till självständiga och ansvarstagande individer och 
samtidigt genomföra en undervisning som förmedlar kunskaper vilka kan komma att testas på ett nationellt prov. Att eleverna blir bildade har givetvis ett högt bruksvärde för dem. Samtidigt kan även goda provresultat vara viktiga då dessa kan ha ett potentiellt stort bytesvärde för eleven då resultatet kan bytas in mot betyg, vilka kan öppna upp för en framtida utbildning. Används dessutom provresultat som ett instrument för att mäta lärarens skicklighet kan det även finnas stort bytesvärde i goda provresultat för den undervisande läraren som ställs inför ett didaktiskt dilemma.

I en andra nivå beskriver Engeström (1987) att motsättningar kan uppstå mellan noderna i verksamhetssystemet. Dessa motsättningar handlar om att objektet i en undervisningsverksamhet förändras till en mer elevaktiv och undersökande undervisning och då kan det skapa spänningar i den arbetsfördelning som finns i form av klassrumsrutiner och lärarroll eller skapa dilemman med regler som betygssättning. En tredje nivå är motsättningar mellan hur verksamheten är i nuläget och hur den potentiellt skulle kunna se ut. Spänningar blottläggs när nya metoder och undervisningsformer introduceras i en verksamhet. Slutligen, på en fjärde nivå, kan motsättningar uppstå mellan den aktuella verksamheten och andra närliggande verksamheter vilket i skolsammanhang kan exemplifieras med att om en skola önskar arbeta med ett tillfälligt förändrat schema det kan innebära en konflikt med arbetsfördelningen i ett närliggande verksamhetssystem, om lärare arbetar på flera skolor eller om lokaler delas.

Engeström (2008) skriver att modellen av verksamhetssystemet för arbete med undervisning kan liknas vid ett isberg. I toppen av isberget, alltså topptriangeln i Engeströms modell, finns de synliga och målinriktade handlingar som lärare och elever utför, instrumenterade av de medierande resurserna. Under ytan finns verksamhetssystemets djupa sociala strukturer och lärarnas vanligtvis homogena bakgrund som skapar stabilitet för verksamheten men även innehåller en tröghet, vilket skapar motsättningar. Dessa ska emellertid inte betraktas negativt som problem och möjliga konflikter, även om de kan utvecklas till sådana, utan detta är strukturella spänningar som 
ofrånkomligen uppstår och ackumuleras över tid i ett verksamhetssystem (Engeström \& Rückriem, 2005) och de ska därför ses som möjligheter till förbättring.

Engeström (2008) menar att det är just dessa motsättningar som kan driva en förändring i verksamheten, och genom att få syn på och ändra på dessa skapas förutsättningar för beständig förändring. Detta lärande bygger på ifrågasättande och uppstår när individerna i verksamhetssystemet blir uppmärksammade på motsättningar och då kan börja ifrågasätta verksamheten. Ligger lösningen utanför individens eller gruppens egen potential kan detta leda till en kollektiv insats för att förändra, utveckla eller omorganisera upphovet till motsättningen. Om varje deltagare får dela med sig av sina erfarenheter och om man gör både kulturhistoriska och aktuella analyser av verksamheten skapas en förståelse för verksamhetssystemets olika delar och de motsättningar som uppstått.

Det kan vara på sin plats att beskriva hur de närliggande begreppen motsättning, spänning och dilemma ska förstås i denna studie. Dessa har en överlappande betydelse och de två förstnämnda används ibland synonymt. Med motsättning avses här de latenta och inneboende konflikter som finns inbyggda i ett verksamhetssystem (Engeström, 1987). När dessa motsättningar synliggörs beskrivs de här som spänningar vilka innehåller en potentiell konflikt mellan olika handlingsalternativ. Alla alternativ kan erbjuda en lösning, men inget innebär en fullständig lösning. När dessa spänningar gör att lärare ställs inför en konkret valsituation i undervisningen benämns det inom studien som ett dilemma. I en litteraturöversikt sammanfattar Chen, Wei och Jiang (2016) ett dilemma i den västerländska diskursen som en situation där man måste välja mellan olika alternativ, men där inget av dem ger en helt tillfredsställande lösning av situationen. Det handlar om att ta hänsyn till olika perspektiv, intressen, krav och målsättningar, vilka ofta inte helt går att förena med varandra.

För att utveckla en verksamhet behöver motsättningarna synliggörs som spänningar så att man kan bearbeta dem och Engeström (1987) 
skriver att man då kan ställas inför motsägelsefulla budskap i form av dilemman. Man upplever att oavsett hur man handlar så får det alltid några negativa konsekvenser. Alnervik (2013) påpekar att det krävs någon form av metakommunikation för att kunna hantera dessa dilemmasituationer på så vis att man höjer sig upp en nivå ovanför den aktuella och motsätter sig de villkor som presenteras. Även om det inte saknas teorier och modeller för hur lärare ska förändra sin undervisning har det historiskt sett visat sig svårt att införa nya sätt rörande undervisning och lärande (Sannino \& Nocon, 2008), både när det gäller reformer uppifrån och skolutveckling underifrån med utgångspunkt på lokal nivå. Skolans verksamhetssystem är kollektiva och komplexa och påverkas av ett flertal både inre och yttre faktorer. Sannino och Nocon förklarar att det kan förefalla som att systemet blivit multiresistent, men genom att synliggöra motsättningarna och dessutom erbjuda lösningar på dessa kan man stödja en bestående förändring av undervisningen.

\section{Didaktiska dilemman}

Dilemman uppstår i valsituationer där det inte finns något uppenbart rätt eller fel. Man måste välja mellan olika motstående alternativ, värderingar, åtaganden eller lojaliteter där inget av valen är helt tillfredsställande (Billig, 1988; Honig, 1996). Att människor upplever spänningar och dilemman ska inte ses som negativt utan istället som en värdefull egenskap menar Billig (1988), eftersom dilemman gör att vi tvingas fundera över saker i vardagen och som följd av detta inleda meningsfulla diskussioner. I denna studie används begreppet didaktiska dilemman för att beskriva de dilemman som lärarna upplever när de planerar, genomför och utvärderar en reflexiv undervisning. Detta begrepp förekommer tidigare i forskningslitteraturen men sparsamt och utan närmare definition. När det används är det som en generell beskrivning av dilemman av didaktisk karaktär som lärare upplever i samband med sin undervisning och i denna studie används det på liknande vis. De didaktiska dilemmana i denna studie diskuteras dessutom i relation till de positioneringar som lärarna intar i den reflexiva undervisning de har intentioner att arbeta med, men de kan även förekomma i annan form av undervisning där lärarna kan positionera sig annorlunda. 
Fransson och Grannäs (2013) menar att lärare i sitt dagliga arbete ofta hamnar i dilemmasituationer. Man måste förhålla sig till formella lagar och regler såväl som till mer informella arbetsrutiner. Vidare måste läraren balansera olika syften för undervisningen mot varandra inriktade mot de tre olika funktioner som utbildningen ska uppfylla (Biesta, 2009). Allt detta ska göras samtidigt som läraren även måste hantera en mångfald av sociala relationer och sammanhang där normer, värderingar, handlingsmönster och förväntningar finns inlagrade och även tar egen form. Detta sker dessutom i en komplex och föränderlig verksamhet där beslut oftast måste tas snabbt i klassrummets dynamiska samspel. Fransson (2012) exemplifierar detta med att beskriva ett dilemma där en lärare har en svagpresterande elev i ett ämne som har behov av att få sitt självförtroende och sin självbild stärkt, men läraren är ålagd att göra en kunskapsbedömning av eleven. Lärarens dilemma består därmed i huruvida den ska tillfredsställa organisationens och styrdokumentens krav att låta eleven göra exempelvis ett visst prov samtidigt som läraren med sin professionella kunskap inser att detta kommer att påverka elevens självförtroende och självbild negativt.

I skolvardagen kan dilemman ibland betraktas som enskilda och frikopplade situationer, men Fransson och Grannäs (2013) menar att dessa dilemman ständigt finns närvarande som resultat av sociala konstruktioner utifrån samhällets struktur skapade av vardagliga positioner och förhandlingar rörande detta. De använder det teoretiska perspektivet dilemmatic space (Honig, 1994) för att beskriva detta komplexa, rörliga, oformliga och svårfångade system med olika aktörer och med olika positioner som man som lärare bara har att manövrera i förhållande till. Honig menar att man ska betrakta dilemmana som om de hela tiden är närvarande i ens liv där man ständigt positionerar sig på multipla och motstridiga axlar av dilemman som skapar ens identitet och handlingsutrymme. Utrymme i tid och rum mellan olika positioner och dess relationer skapar ett dilemmatic space. Honig hävdar att dilemman är följder av outplånliga konflikter och spänningar som kan finnas inom en yrkespraktik. Det är dessa som antingen bevarar eller förändrar praktiken. 
Begreppet dilemmatic space låter sig inte enkelt översättas till svenska då "space" har fler betydelser än bara fysiska rum och även kan ha både tidsmässiga och mentala dimensioner samt inte minst relationella. För att inte gå miste om dessa dimensioner används därför den engelska benämningen här. Fransson (2012) beskriver hur läraren hela tiden intar olika positioner och ståndpunkter utifrån erfarenheter, gällande regler och normer och det omgivande sociala sammanhanget. Detta skapar ett "space" av dilemman där olika normer, värderingar, handlingsalternativ, beslut och roller positioneras i relation till varandra.

Även om Engeström (1987) har en mer kollektiv ansats är det möjligt att dra paralleller mellan hans verksamhetssystem och dilemmatic space. Engeström menar att mänsklig verksamhet, som exempelvis undervisning, kan ses som ett komplext verksamhetssystem där det finns olika perspektiv, intressen och traditioner. Verksamhetssystemet har utvecklats kulturhistoriskt och det uppstår motsättningar i och mellan olika delar i systemet över tid. Både verksamhetsteori och perspektivet dilemmatic space tar helhetsgrepp och ser mänskliga aktioner som ingående i en större helhet av olika ingående delar vilket innebär att dessa förklaringsmodeller överlappar varandra. Båda perspektiven ser motsättningarna och spänningarna som drivkraften i att förändra en praktik. Samtidigt har perspektiven även sina olikheter vilket kan innebära att de har olika potentiella förklaringsvärden för ens data, och därigenom kan perspektiven komplettera varandra.

Olika typer av skolpolitiska beslut, administrativa beslut på skolnivå eller undervisningsinnovationer kan förändra normer, värderingar, handlingsalternativ och relationer och då förändras undervisningens dilemmatic space. Likaså kan en större samhällsomvandling påverka relationer och positioner vilket påverkar dilemmana (Fransson \& Grannäs, 2013). Genom diskussioner mellan lärare kan detta leda till nya positioneringar och relationer varvid "spacet" förändras. Fransson, (2017) beskriver att dilemman, till skillnad från problem, inte helt och hållet kan lösas. Det handlar istället om att hitta det 
bästa möjliga alternativet genom att göra avvägningar mellan möjligheter och konsekvenser. Som regel blir det kvar en obekväm känsla som påminnelse efter att man valt handlingsalternativ. Han menar vidare att positioner som intas beträffande ett dilemma i undervisningen bäst förstås när positionen relateras till andra möjliga positioneringar.

Att dilemman inte helt och hållet kan ha en tillfredsställande lösning kan vara anledningen till att man ibland till vardags betraktar dilemmasituationer som negativa. Genom analyser utifrån dilemmatic space kan positioner, och dynamiska relationer mellan dessa, synliggöras från mikro- till makronivå (Fransson, 2012). Detta gör enligt Fransson att utbildningssystemet, och förändringar av detta, kan förstås och skärpa lärares professionsteoretiska analyser av sin verksamhet. Även Engeström (1987) betonar att förändringspotentialen i ett verksamhetssystem ligger i att synliggöra de motsättningar som uppstår i detsamma.

\section{Didaktiska modeller}

När lärare arbetar med en reflexiv undervisning innebär det att denna delvis kan ha andra syften och motiv än lärarens gängse undervisning. Då är det inte säkert att allt det förgivettagna längre är helt giltig. I utvecklingsprocesser är det avgörande att läraren utvärderar vilka förgivettaganden som fortfarande är giltiga och aktivt värderar olika handlingsalternativ. Eftersom en lärare inte rimligtvis kan fatta alla snabba beslut i klassrummet helt genomtänkt och medvetet, framstår en form av paradox. En del saker behöver vara operationaliserade och förgivettagna för att skolvardagen ska fungera smidigt. På samma gång behöver det förgivettagna i ens praktik ständigt ifrågasättas. Ett växelspel krävs där lärare behöver ha förgivettagna didaktiska strategier att använda sig av i hastigt uppkomna situationer i klassrumsvardagen men även hela tiden utveckla strategierna för hur undervisningen ska bedrivas. Samuelsson och Colnerud (2015) menar att läraren måste hantera situationer som dilemman med hjälp av didaktisk kompetens, sitt klassrumsledarskap, sin ämneskompetens och sociala kompetens. Med detta kan läraren välja det lämpligaste sättet att agera i en given situation i den 
aktuella kontexten. Det finns inga generella lagar eller procedurer att följa, utan läraren måste hitta balans mellan olika motstående positioner eller handlingsalternativ.

Wiliam (2009) menar att lärare inte primärt behöver någon som beskriver för dem hur de ska göra, utan det som behövs är systematiska metoder för att reflektera över sin egen praktik, lära av sina misstag och bygga vidare på professionens tillgängliga kunskapsbas. Kollegialt lärande där lärare tillsammans reflekterar över sin undervisning kan skapa förutsättningar för att stärka lärarens kunskap att hantera didaktiska dilemman i undervisningen. Med hjälp av verktyg att använda vid kollegiala diskussioner kan lärare tillsammans skilja bättre prestationer från sämre för att sedan kunna utföra gynnsammare didaktiska val. För att lärare ska utveckla en praktisk kunskap är reflektion och diskussion avgörande (Schön, 1983) och detta måste ske i nära anslutning till det praktiska handlandet. Schön menar att det är viktigt att det förgivettagna i verksamheten medvetandegörs och att det tillförs ny kunskap och nya tankemönster genom handledning.

Ovannämnda anglosaxiska forskningsrön är något som sedan länge varit ett fundament i den europeiska didaktiktraditionen (Sjöström, under utgivning). Ingerman och Wickman (2015) beskriver didaktiska modeller som ett sätt att introducera lärare till en mer generell didaktisk analys. I förlängningen kan dessa hjälpa lärarna i deras didaktiska val av innehåll och metoder. De är verktyg för läraren att planera, utföra och utvärdera undervisningen och de kan bidra till både en didaktisk analys och att ge lärare ett gemensamt språk i diskussioner om undervisning. Didaktiska modeller bygger enligt Wickman på antaganden om hur didaktisk teori kan växelverka med undervisningspraktiken.

Att arbeta med didaktiska modeller har traditionellt använts inom den tyska didaktiken där mycket kan spåras tillbaka till Klafkis didaktiska analyser från 1950-talet med fem generella didaktiska frågor (Klafki, 1995). Frågorna rör vad den aktuella undervisningens 
innehåll syftar till att utveckla hos eleverna, på vilka sätt undervisningsinnehållet har betydelse för eleverna, dels i dagsläget och dels i framtiden, hur svaren på ovannämnda frågor vidare avspeglar sig $\mathrm{i}$ hur undervisningen struktureras och slutligen hur innehållet görs intressant och tillgängligt för eleverna. Dessa frågor är inte riktade till någon särskild skolform, ålder på barnen eller ämne, utan det är upp till läraren att omvandla detta till sin egen situation. Didaktiska modeller kan stödja läraren att hantera den didaktiska Varför-frågan genom att ge skäl till varför man ska göra det man gör i sin undervisning.

Att arbeta med didaktiska modeller är inte endast en teoretisk fråga utan i högsta grad en empirisk fråga. Ingerman och Wickman (2015) menar att forskningsansatsen didaktisk modellering är forskning som testar en didaktisk modell i undervisningspraktiken. Den didaktiska modellen kan ses som ett paket med en teoretisk bas innehållande kunskapssyn och didaktiska referenspunkter, men utformningen av modellen omförhandlas när den används i praktiken och utvecklas därmed. Det blir ett lärande för alla involverade parter och det finns ett gemensamt ansvar och risktagande mellan akademi och praktik. För forskaren i ett didaktiskt modelleringsprojekt är uppgiften att extrahera kunskaper ur studien och förstå principer för vad som händer när lärarna arbetar med en introducerad didaktisk modell. De upptäckter som forskaren gör tas emellertid inte för givna utan dessa förs tillbaka till praktiken där upptäckterna i form av uppdaterad didaktisk modell ruckas och omskapas i praktiken (Pickering, 1995). Genom denna process kan forskaren explicitgöra hur en didaktisk modell kan hjälpa lärare att hantera en didaktisk situation.

\section{Summering av studiens teoretiska utgångspunkter}

En reflexiv undervisning tar sin utgångspunkt i samhällsdilemman och eleverna arbetar med komplexa frågor på en sociopolitisk nivå där det inte finns en enskild lösning som är helt tillfredsställande. Frågorna är viktiga framtidsfrågor för vårt samhälle och för att hantera dessa krävs reflexiva medborgare med självmedvetenhet om de 
egna sociala villkoren och den egna platsen i tillvaron. De behöver både ta ansvar för och kunna ifrågasätta samhällsutvecklingen.

Det är inte bara elevuppgifterna i den reflexiva undervisningen som innehåller dilemman och som är komplexa. Den reflexiva undervisningen i sig är syfteskomplex och ställer läraren inför olika didaktiska dilemman. Den reflexiva undervisningen utmanar alltså inte endast eleverna att vara reflexiva, utan även läraren. Denne måste vara reflexiv i planering, utförande och utvärdering av denna undervisning och kritiskt granska spänningar och dilemman i den egna praktiken. Detta behöver göras med en medvetenhet om undervisningens villkor och skolans plats i tillvaron samt med en förståelse för undervisningens syfteskomplexitet. 


\section{METOD}

Detta kapitel redogör och argumenterar för de olika val som gjorts med avseende på syften, forskningsfrågor, datainsamling och analys samt beskriver forskningsprocessen i stort. I de efterföljande kapitlen kommer datainsamling och analysprocess att fördjupas ytterligare. För att läsaren ska få ett sammanhang beskriver jag initialt de skolor som deltog i studien samt den undervisningsmodell som var grunden för den undervisning som studerades.

\section{Kontexten för studien}

Studien följde fem europeiska grundskolor som arbetade tillsammans inom ett EU-finansierat skolutvecklingsprojekt, Erasmus+ mellan 2014 och 2016. Strategiska partnerskap som detta syftar till att skapa möjligheter för organisationer att samarbeta med organisationer i andra europeiska länder och det kan handla om utveckling och överföring av arbetssätt, modeller och metoder, kompetensutvecklingsinsatser eller erfarenhetsutbyten (Universitets- och högskolerådet, 2016).

Skolorna som samarbetade var från Sverige, Polen, Italien, Kroatien och Turkiet och eleverna var i åldern 12-15 år ${ }^{1}$. I skolornas gemensamma ansökan för sitt tvååriga skolutvecklingsprojekt beskrev de att de ville utveckla och testa ämnesövergripande och frågebaserade arbetssätt genom att arbeta med hållbarhetsfrågor. Under projektets gång genomfördes två projektmöten där endast lärare deltog samt tre elevutbyten där både elever och lärare deltog. Vid samtliga fem sammankomster följde jag lärarna och jag genomförde dessutom deltagande observationer på samtliga fem skolor under projektets andra år.

Eleverna på den turkiska skolan var 9-10 år. 
Det ska noteras att Erasmus+ partnerskapet formerades och skolornas ansökan för detta partnerskap gjordes innan min ansökan till licentiatutbildning. Men då jag tidigare arbetat på den svenska skolan och även haft erfarenhet av tidigare internationella utvecklingsprojekt hjälpte jag till i skolornas ansökningsprocess och var därför väl förtrogen med organisationen av, och tankarna i, detta projekt. När det vid ungefär samma tidpunkt stod klart att jag antagits till forskarutbildning och att skolornas partnerskapsansökan beviljats, uppstod idén att jag skulle använda skolornas utvecklingsprojekt som mitt studieobjekt. Därför frågade jag skolorna om möjligheten att få följa deras arbete som en forskningsstudie, vilket de accepterade.

Det faktum att jag hade god insyn i skolornas samarbetsprojekt och en koppling till den svenska skolan innebar en stor tillgänglighet för mig i min studie. Det som dock var avgörande för att välja att studera just detta samarbete var att detta var sammansatt av skolor från länder som skiljer sig från en svensk kontext, speciellt i avseende på den form av undervisning som man skulle arbeta med. Med ansatsen att genom komparativ didaktik göra jämförelser för att synliggöra det förgivettagna, innebar variationen i sammansättningen goda förutsättningar för detta. Komparativa analyser har potential att undersöka undervisningsverkligheten från klassrummets enskilda händelser på mikronivå, via skolans institutionella nivå till makronivå med traditioner och läroplaner för att utforska olika rådande värderingar och vanor samt andra underliggande antaganden kring undervisningen (Ligozat, Amade-Escot \& Östman, 2015).

Den svenska skolan är en större högstadieskola belägen i en medelstor svensk stad. Elever i två klasser deltog i arbetet inom projektet och de arbetade med arbetsuppgifterna. Det genomfördes delvis på specifika tillvalslektioner avsedda för Erasmus+ partnerskapet där ungefär hälften av de två klassernas elever deltog. En del av den reflexiva undervisningen genomfördes emellertid på ordinarie lektioner med hela klasserna, bland annat under en temadag. Sex olika lärare med olika ämneskompetenser var involverade i undervisningen, dock i olika omfattning. Den polska skolan var en skola av 
motsvarande storlek som den svenska, belägen i en mindre ort på polska landsbygden. Den reflexiva undervisningen genomfördes där inom ramen för elevens val med elever som valt detta själva. Undervisningen genomfördes av en grupp bestående sex lärare, jämnt fördelat på NO-lärare, SO-lärare och språklärare. Den kroatiska skolan inom partnerskapet var enparallellig och ligger i en mindre kustort präglad av turistindustrin. På samma vis som på den polska skolan arbetade man enbart med frivilligt deltagande elever, mestadels på elevens val-liknande lektioner. Dessa lektioner leddes i huvudsak av två engelsklärare, en SO/NO-lärare, en NO-lärare samt en idrottslärare.

Den italienska skolan är precis som den kroatiska belägen i en mindre kustort med turismen som viktigaste näring. Skolan är emellertid betydligt större än den kroatiska och här involverades alla elever i de deltagande årskurserna. Arbetet genomfördes under ordinarie lektioner och därför var över tio olika ämneslärare involverade, varav nio deltog i denna studies datainsamling. Den turkiska skolan slutligen, ligger i en socioekonomiskt utsatt del av en storstad och är en mycket stor skola med många klasser och med många elever i varje klass. Då eleverna var något yngre arbetade man med ett urval av arbetsuppgifterna och gjorde det både på elevens val-tid och på ordinarie lektioner. I denna studie deltog fem klasslärare och två engelsklärare i fokusgruppsintervjuer och vid den deltagande observationen. Utöver lärare på de olika skolorna deltog även rektorer i Erasmus+ partnerskapet och en del av dessa var delaktiga i arbetet med den reflexiva undervisningen samt deltog även i fokusgruppsintervjuer inom studien.

I föreliggande studie lades fokus på de svenska deltagarnas upplevelser av didaktiska dilemman, vilka kunde synliggöras och fördjupas genom speglingen mot övriga deltagares upplevelser. Det är på sin plats att beskriva dessa deltagares bakgrund närmare, inte minst eftersom de har en förhållandevis homogen erfarenhetsbas. När det gäller att ha praktisk kunskap i den komplexa verksamhet som undervisning är, spelar erfarenheter och tidigare upplevelser en stor roll (Bronfenbrenner, 1992). 
Samtliga de svenska deltagarna som deltog i studien är i åldersspannet 45-55 år och de tog sin lärarexamen någon gång i mitten av 90talet. De involverade lärarna har dessutom arbetat mer än femton år på den aktuella skolan och har därför formats inom samma skolkultur. Vid en allmän betraktelse får man anse att skolan har varit utvecklingsbenägen under denna tidsperiod och varit tidigt ute med att anamma innovationer och trender inom skola och undervisning. Detta kan exemplifieras med att man tidigt började att arbeta i arbetslag; man utvecklade en individualiserad undervisning med olika former av eget arbete. En av de tre F-6-skolor varifrån skolans elever kommer ifrån är dessutom en Montessoriskola, vilket också till viss del har influerat skolans undervisning i denna riktning. Man har i perioder arbetat en hel del med ämnesövergripande arbetssätt och var snabbt ute med att integrera IKT i undervisningen och eleverna har sedan flera år tillbaka varsin dator. Man har även under lång tid arbetat med elevdelaktighet och elevansvar och med det som nu definieras som formativ bedömning.

Två grundstenar i verksamhetsteorin är flerstämmighet och historicitet vilket betonar att alla deltagare i ett verksamhetssystem bär med sig sina personliga historier och synsätt samt att verksamheten måste förstås i belysning av sin historia på olika nivåer (Engeström, 2001). Den förställning om vad som är god undervisning som deltagarna i studien bär med sig har formats utifrån att de en gång själv var elever, genom deras lärarutbildning, till att de nu arbetar som lärare. Sundberg (2015) beskriver att tyngdpunkterna för vad som räknas som kunskap i den svenska skolan har skiftat sedan den första läroplanen för den obligatoriska grundskolan togs fram 1962 till idag. Om man följer Sundbergs beskrivningar av de senaste läroplanernas konstruktioner och kunskapsemfaser kan man säga att de svenska deltagarna gick sina första skolår i en innehållsfokuserad läroplan, Lgr 69, men merparten av deras skolgång och även delar av sin lärarutbildning genomfördes i en skola styrd av en processfokuserande läroplan, Lgr 80.

Enligt Sundberg (2015) karakteriserades Lgr 80 av beskrivningar av önskvärda utvecklingsprocesser hos eleverna så att de utvecklades 
personligt men även som samhällsmedborgare. Resultatet av dessa processer lämnades emellertid över till läraren att anpassa efter lokala förutsättningar. Det fanns samtidigt kvar en stark central regeloch detaljstyrning i läroplanen och kritik av detta ledde fram till Lpo 94 vilket var en målstyrd och kompetensfokuserande läroplan där stort ansvar lades på lärarens professionalitet. Det var i samband med att denna nya läroplan infördes som de medverkande lärarna kom ut som färdigutbildade lärare och gjorde sina första arbetsår. Sundberg beskriver hur denna läroplan fick en svag implementering och lärarna fick med kort omställningstid ta stort eget ansvar för att fatta beslut om urval, organisation och bedömning inom undervisningen och i denna process var studiens deltagare då oerfarna lärare. $\mathrm{Nu}$ arbetar deltagarna efter en ny läroplan, Lgr 11, som Sundberg beskriver som en resultatfokuserande läroplan. I denna finns ett starkt fokus på utfall och bedömning av mätbara mål och återigen detaljstyrning i kursplanerna i form av centralt innehåll och kunskapskrav.

\section{Studiens undervisningsmodell}

För att hjälpa lärarna över den tröskel som finns för att arbeta med en reflexiv undervisning skapades en undervisningsmodell. Undervisningsmodellen avsåg att underlätta för lärarna att skapa en undervisning efter de intentioner som beskrivits tidigare kring en reflexiv undervisning. Olika spänningar och didaktiska dilemman som är inbyggda i undervisningens komplexitet medförde att den praktiska undervisningen på skolorna inte fullt ut blev reflexiv, trots den reflexiva intentionen. Det är just dessa spänningar och didaktiska dilemman som studien ämnade att studera. Det som i texten beskrivs som en reflexiv undervisning ska alltså som berörts tidigare förstås som en intentionellt reflexiv undervisning.

Det ingick en av mig skapad elevuppgift, som gick som en röd tråd genom skolornas arbete under de två åren. Arbetet var indelat i fem olika ämnesområden med olika kontroversiella hållbarhetsämnen med innehåll som rörde teknik, natur, människa samt samhälle, vilka i de flesta fall har en sociopolitisk dimension och etiska inslag. Elevuppgiften placerar eleverna i ett scenario där de hamnat på en 
imaginär och nyligen koloniserad planet vid namn PromethEUs. Denna är ursprungligen inspirerad av en elevuppgift i boken Solvagnen (Brunner 1997), men uppgiften har sedan jag själv utvecklat efter hand som lärare.

Elevernas uppgift under Erasmus+ partnerskapets gång var att arbeta med att bygga upp en ny civilisation på planeten genom att fatta beslut på strukturell nivå rörande områden som styrelseskick, ekonomiska system, energisystem, sociala frågor, religion, användning av bioteknik och robotar. Samhällsdilemmana delades upp på fem ämnesområden vilka sedan innehöll upp till tio problemområden till vilka en eller ett par specifika frågor formulerades. Som stöd för lärarna att sätta sig in i problemområdet fick de en sammanställning med olika aspekter och argument gällande samhällsdilemmana som eleverna skulle arbeta med.

Frågorna var medvetet utvalda för att vara öppna och kontroversiella samt av dilemmakaraktär där inte ett rätt svar skulle finnas. Arbetsuppgiften hade ett övergripande mål att utveckla elevernas förmågor, som ligger till grund för att självständigt fatta beslut och uttrycka etiska och politiska ställningstaganden och göra det i ett europeiskt sammanhang. Eleverna uppmanades att ta ställning baserat dels på kunskaper om de mänskliga rättigheterna och de grundläggande demokratiska värderingarna, dels på personliga erfarenheter och faktakunskap. En genomgående följemening (Östman, 1995; Roberts \& Östman, 1998) i undervisningen var att förmedla att politiska beslut kring komplexa frågor med både naturvetenskapliga, sociala, ekonomiska och etiska aspekter inte handlar om rätt eller fel, utan snarare är dilemman där det handlar om att väga fördelar mot nackdelar och i denna process fatta ett rimligt och acceptabelt beslut.

Frågeställningarna hade överlag innehåll från flera skolämnen men några hade mer fokus på SO-ämnen, medan andra hade tydligare kunskapsinnehåll från NO-ämnen eller teknikämnet. Nedan finns exempel från de fem ämnesområdena på samhällsdilemman med ett naturvetenskapligt och tekniskt innehåll. För att diskutera frågorna 
behöver ofta även etiska, filosofiska och sociopolitiska aspekter beaktas och frågorna berör även ämnesinnehåll från andra skolämnen.

Från ämnesområdet Sustainable Government och problemområdet lagring av individers genetiska information:

Should genetic information that is about individuals' DNA be stored in a database on PromethEUs?

If so, whose DNA would be stored?

- Everyone?

- Convicted criminals?

- Persons that have been in a criminal investigation?

- People with genetic diseases?

- Others?

If there will be a DNA database PromethEUs, who will have access to it?

- Everyone?

- The police?

- Scientific researchers?

- Insurance companies?

- Job employers?

- Others?

Från ämnesområdet Sustainable Living och problemområdet användandet av assisterad befruktning:

Should In vitro fertilization (IVF), "test tube babies", be used on PromethEUs?

If so, for whom will it be used of the groups below?

- People with medicine conditions that prevents normal pregnancy?

- For single mothers?

- For gay couples?

Från ämnesområdet Sustainable Economy och problemområdet ohälsosam mat och övervikt: 
Should high-calorie/low-nutrient food have higher tax compared to healthier food, so called "fat-taxes and "sugar-taxes"?

Från ämnesområdet Sustainable Energy och problemområdet energianvändning:

Will some types of products or everyday activities be banned or regulated to ensure efficient energy use on PromethEUs?

- Food that needs much energy in the production of it will be limited?

- Only recyclable product is allowed be sold on PromethEUs?

- People's possibilities for leisure travelling will be limited?

- Or should these things be up to the individual to decide?

Will digital technology be used for sustainability reasons to:

- Monitor the energy use at people's homes to ensure that people don't use energy inefficient?

- Weighing and storing information about home's waste to encourage recycling and reuse?

- Controlling people's car driving by storing information from gps to ensure that people are making energy efficient trips?

- Storing information about people's long-distance flight and train traveling for energy efficiency and security reasons?

De deltagande observationer som jag genomförde gjordes i samband med att eleverna arbetade med ämnesområdet Sustainable Innovations. Ett problemområde inom detta rörde synen på funktionshindrade personer som i framtiden kommer få robotproteser:

Different kind of robotic prosthesis may mean a lot to give people with disabilities, congenital or due to some accident, a good life. Should so called cyborgs, humans with artificial parts, be allowed 
take part in sports, like the Olympics or FIFA World Cup?

För att få eleverna att utveckla förmågor som behövs för att kunna arbeta med samhällsdilemman och ta ställning i komplexa och kontroversiella frågor engagerades eleverna först i form av konkreta frågeställningar som de kunde positionera sig kring utifrån sina vardagskunskaper. För att introducera eleverna och skapa en känslomässig upplevelse visades aktuella filmklipp kring ämnet och värderingsövningar som Heta stolen och Fyra hörn genomfördes. Detta skulle vara en grund för kommande undersökningar och meningsskapande kring ämnet och de olika problemen som ingick.

För att stödja lärarna innehöll undervisningsmodellen en beskrivning av en arbetsgång för hur de skulle kunna organisera ett undersökande arbetssätt i denna reflexiva undervisning. Den baserades teoretiskt i metodiska arbetsmodeller av Bybee m.fl. (2006) och Presley m.fl. (2013) kring att arbeta undersökande, där även inspiration hämtades från Ekborg m.fl. (2012) samt Zeidler och Kahn (2014). Lärarna arbetade med eleverna i tre steg, där de i det första steget introducerade eleverna i ämnesinnehållet genom att engagera eleverna med hjälp av film, värderingsövningar och diskussioner. I nästa steg arbetade man med de olika specifika frågeställningarna som hörde till ämnesområdet där eleverna undersökte och satte sig in i frågorna och tog ställning $\mathrm{i}$ frågorna. I undervisningsmodellen ingick modeller för lärarna beträffande kritisk granskande och beslutsfattande (Pedretti, 1999; Zeidler \& Keefer, 2003), modeller för hur man kan bygga upp argument med både antika och mer samtida modeller (Toulmin, 1958; Chang \& Chiu, 2008) och olika sätt att förhålla sig till vid elevdiskussionerna (Mouffe, 1999; Öhman \& Öhman, 2012).

I det tredje steget diskuterade eleverna med varandra för att gemensamt fatta beslut på sin skola och dessa beslut sammanställdes med det webbaserade serieteckningsverktyget Creaza Cartoonist. Med dessa seriestrippar delades skolornas olika förslag på lösningar mellan varandra. I samband med Erasmus+ partnerskapets tre elevutby- 
ten genomfördes sedan totalt fem internationella diskussioner kallade "förhandlingar", där representanter från skolorna diskuterade för att fatta ett gemensamt beslut om vad som skulle gälla på den imaginära planeten PromethEUs. Detta skedde under ledning av en lärare som var förhandlingsledare.

När skolorna arbetade med det femte ämnesområdet, vilket innehöll frågeställningar som rör användning av robotar och tekniker för att skapa syntetiskt liv i ett framtidsscenario, organiserade skolorna arbete med detta i form av en temadag där jag deltog och genomförde deltagande observationer. I övrigt arbetade skolorna med denna undervisning på speciellt avsatta lektioner ungefär en gång i veckan.

Den avslutande delen, då elever argumenterade och diskuterade kring frågorna i en internationell kontext, var en viktig del av undervisningsmodellen. För att detta skulle fungera effektivt krävdes givetvis att de ingående frågeställningarna att arbeta med var gemensamma för alla skolor. Interventionen som studiens undervisningsmodell kan ses som var i övrigt inte i form av en detaljerad arbetsbeskrivning för de deltagande praktikerna att slaviskt följa. Den är istället att betrakta som paket med stöttor för lärarna att använda och en riktningsvisare för att hjälpa dem på vägen.

För att stödja lärarna ytterligare i arbetet med elevuppgiften sattes det hela också in i ett större didaktiskt sammanhang av ett teoretiskt ramverk som jag förmedlade till deltagarna i samband med de olika träffarna inom projektet. Modellen var således inte fast och färdig, utan genom kontinuerlig dialog och kollegialt lärande testades den för att utvecklas i samspel mellan mig och de medverkande. Hur arbetet organiserades och utfördes var emellertid öppet för de deltagande skolorna att bestämma över och grundtanken var att de deltagande lärarna själva skulle anpassa arbetet utefter sina förutsättningar. De skillnader som skulle uppstå skulle i sin tur vara en grundförutsättning för diskussioner och ett lärande mellan lärare från olika deltagarländer. 


\section{Den ämnesövergripande inriktningen}

I studien handlade mitt huvudsakliga intresse om frågor med kunskapsinnehåll från såväl SO-ämnen, NO-ämnen som teknik. I samband med mina deltagande observationer var det denna typ av frågeställningar som skolorna arbetade med genom ämnesövergripande lärarsamarbete. I samband med fokusgruppsintervjuer och övriga samtal under arbetets gång relaterade emellertid också lärarna till erfarenheter av didaktiska dilemman rörande elevdiskussioner och annan undervisning av reflexiv sort som lärarna haft i andra sammanhang och i mer ämnesspecifik undervisning. Att relatera till sina tidigare erfarenheter är dock en självklarhet i en fokusgruppsdiskussion och därför oundvikligt.

Studiens ämnesövergripande fokus innebär dessutom att lärare med olika typer av ämnesbehörigheter deltog i arbetet. En del lärare hade naturvetenskaplig ämnesbehörighet, andra undervisade i samhällsvetenskapliga ämnen och några hade behörighet inom båda ämnesfälten. Det fanns även med lärare som var rena språklärare och lärare som undervisade i praktiska och estetiska ämnen. Då avsikten med studien var att studera didaktiska dilemman som uppstod i en reflexiv undervisning kring ämnesövergripande hållbarhetsfrågor gjordes ingen åtskillnad mellan lärare beroende på deras ämnesbakgrund, då alla var med och arbetade tillsammans med dessa frågeställningar som berörde teknik, natur, människa och samhälle.

Studien beskriver inte specifikt hur NO-lärarna eller tekniklärarna beskriver denna reflexiva undervisning, utan hur lärarna beskriver den. Intresset för studien ligger på just didaktiska dilemman i fältet där naturvetenskap, teknik, samhällsvetenskap, etik, politik och språk möts. Ett fokus på lärare med en specifik ämnesbehörighet skulle förvisso också kunna ge intressanta svar då det inte är otänkbart att det kan finnas skillnader mellan lärare i olika skolämnen. Samtidigt finns även en variation mellan lärare som undervisar inom samma ämnen. Med tanke på denna studies syften, upplägg och dess forskningsfrågor är det emellertid lärare generellt som studeras och de dilemman som de upplever i arbetet med denna form av undervisning. 


\section{Studiens forskningsfrågor}

Mitt forskningsintresse som jag gick in i studien med var att belysa de möjligheter och hinder som finns för att förändra sin praktik genom att arbeta med en annorlunda form av undervisning. I detta fall var fokus på en undervisning där eleverna arbetar med kontroversiella och ämnesövergripande samhällsdilemman, vilka eleverna analyserar för att sedan diskutera. Angående dessa samhällsdilemman är fokus inte bara på ämnesinnehållet i dilemmat, utan intentionen är även att utveckla elevernas förmågor kring kritiskt tänkande och dessutom att bidra till deras utveckling till ansvarstagande och självständiga medborgare. När undervisningen har flera syften uppstår spänningar och didaktiska dilemma.

Studien tog sin utgångspunkt i att följa de fem skolornas intentionellt reflexiva undervisning. Jag diskuterade regelbundet med lärarna kring de spänningar och didaktiska dilemman som de upplevde i utformandet av en reflexiv undervisning. Förutom att dessa diskussioner skulle förse mig med data var ändamålet även att skapa förutsättningar för de medverkande att förstå sin egen verksamhet på ett nytt sätt, genom att urskilja aspekter i den variation av beskrivningar av dilemman som uppstår. Detta är i linje med det dubbla uppdrag man åtar sig genom att bedriva forskning på förändringsprocesser (Engeström, 1987; Chaiklin, Hedegaard \& Juul Jensen, 1999; Roth \& Tobin, 2002). Som forskare handlar det i dessa sammanhang inte bara om att med sin studie öka kunskap och teoretisk förståelse om det aktuella fenomenet utan även om att stödja de medverkande i deras egna förändringsprocesser.

En utgångspunkt för min design var att jag ville studera de didaktiska dilemman som uppstår när lärare arbetar med en reflexiv undervisning. Det finns en hel del utmaningar som har att göra med brist på utbildning, erfarenhet och läromedel som skapar omedelbara hinder, vilka inte sällan innebär att ingen eller begränsad mängd undervisning av denna typ genomförs (Aikenhead, 2006; Robottom, 2012). För att skolor ska lyckas att transformera sin undervisning i denna riktning är det avgörande att alla inblandade är medvetna inte om bara möjligheterna utan även om de utmaningar som 
kan vänta (Ekborg, Ottander, Silfver \& Simon, 2013). För att ge skolorna förutsättningar att arbeta med en reflexiv undervisning skapade jag en undervisningsmodell vilken stöttade lärarna att skapa ämnesövergripande undervisningsarenor, både lokalt på skolorna och i samband med internationella elevutbyten inom Erasmus+ partnerskapet. Med stöd av detta kunde lärarna ta sig förbi de instegshinder som det visat sig att lärare ofta upplever när de ska arbeta med denna form av undervisning. Detta gav mig i sin tur möjlighet att utforska de didaktiska dilemman som lärarna upplever när de arbetar med en reflexiv undervisning.

Lärarna på de olika skolorna arbetade med den reflexiva undervisningen på olika vis och gjorde lite olika didaktiska val. Även om de upplevda spänningarna på respektive skola påminde om varandra fanns det även skillnader. Det fanns dels en variation i hur påtaglig en spänning upplevdes vara, dels skillnader i hur lärarna positionerade sig. Denna variation skapar en gynnsam utgångspunkt för att göra jämförelser. Forskningsfrågan I a. kan därför betraktas som en grund för studiens komparationer.

I a. Vilka spänningar upplever lärarna i en reflexiv undervisning?

I kapitlet Fas I redogörs för de olika spänningar som upplevdes och forskningsfrågan besvaras. Detta leder fram till forskningsfrågan I b. som är kopplad till den förra.

I b. Hur positionerar sig de olika lärarna i de spänningar som identifieras?

Baserat på min egen bakgrund i den svenska skolkontexten ville jag närmare undersöka hur studiens svenska lärare upplevde de didaktiska dilemma som spänningarna gav upphov till. Jag ville vidare fördjupa kunskaperna om de svenska lärarnas förgivettagna positioner i dessa. Ett urval gjordes av de beskrivna spänningarna i den reflexiva undervisningen, där de som upplevdes som mer påtagliga 
för de svenska deltagarna prioriterades. Analyser av dessa spänningar beskrivs i andra delen av kapitlet Fas I och svarar mot forskningsfrågan $\mathrm{I} b$.

En fokusgruppsintervju med de svenska deltagarna genomfördes med utgångspunkt i forskningsfrågan II. Denna besvaras i kapitlet Fas II där olika positioner i de didaktiska dilemmana diskuteras.

II. Vad synliggörs när de svenska lärarna reflekterar kring sina egna positioneringar i de didaktiska dilemmana då de speglar sig i andras positioner?

Studien hade ävensom syfte att de empiriska resultaten skulle kunna omformuleras till ett diskussions- och reflektionsverktyg. Denna didaktiska modell kan erbjuda lärare, och lärarstudenter, stöd för att diskutera och reflektera kring didaktiska dilemman som uppstår när man arbetar med en reflexiv undervisning.

III. Hur kan empirin ligga till grund för en didaktisk modell för didaktiska diskussioner i lärares fortbildning?

I kapitlet Fas III beskrivs hur svaren på studiens tidigare forskningsfrågor resulterar i ett underlag för en didaktisk modell genom vilken studiens genererade kunskap kan bidra till att utveckla undervisningspraktiken.

De två första forskningsfrågorna svarar på vilka spänningar som framträder för de deltagande lärarna och de olika positioneringar som lärargrupperna intog i de didaktiska dilemman de ställs inför på grund av dessa spänningar. Den tredje frågan undersöker dessa didaktiska dilemmans väsen mer specifikt för de svenska deltagarna medan den fjärde är inriktad mot hur kunskaper från studien kan överföras till praktiken. Studiens fyra forskningsfrågor är alltså:

I a. Vilka spänningar upplever lärarna i en reflexiv undervisning?

I b. Hur positionerar sig de olika lärarna i de spänningar som 
identifieras?

II. Vad synliggörs när de svenska lärarna reflekterar kring sina egna positioneringar i de didaktiska dilemmana då de speglar sig $i$ andras positioner?

III. Hur kan empirin ligga till grund för en didaktisk modell för didaktiska diskussioner i lärares fortbildning?

\section{Metodologiska utgångspunkter}

Med synsättet att didaktik är lärares professionsvetenskap (Seel, 1999) föll det sig naturligt att lärarna skulle vara delaktiga i studien. Den gemensamma grunden i form av studiens undervisningsmodell och den internationella sammansättningen innebar en variation i lärarnas didaktiska val och positioneringar. Detta gav goda förutsättningar för lärarna att jämföra egna erfarenheter med övriga deltagares och för att därigenom synliggöra det förgivettagna. Denna variationen, samt möjligheten att ha återkommande datainsamlingar, innebar att det fanns goda möjligheter att få ut stora mängder data för att undersöka spänningar och didaktiska dilemman.

Helhetsperspektiv på undervisning

Som berörts i förra kapitlet finns en överlappning mellan de i denna uppsats frekvent använda uttrycken spänning och didaktiska dilemman. Spänningar handlar i detta sammanhang om den inneboende komplexitet som finns i undervisningen till följd av de invanda motsättningar som finns mellan olika delar i undervisningens verksamhetssystem. När dessa spänningar tar sig uttryck i konkreta valsituationer för läraren att hantera i undervisningspraktiken benämns detta i denna studie som didaktiskt dilemman. Det kan vara en spänning mellan elevcentrerade undervisningsmetoder och en undervisning som är mer inriktad på lärarens som klassrummets primära kunskapsförmedlare. Detta kan skapa ett didaktiskt dilemma för läraren som gäller hur eleverna ska tillskansa sig information kring olika aspekter av ett samhällsdilemma. Läraren måste göra en avvägning i vilken utsträckning denne ska låta eleverna själva samla in information, i förhållande till att läraren tar ansvar för att förmedla 
relevant information. En viss spänning kan dessutom ge upphov till olika varianter av didaktiska dilemman beroende på kontexten och ett didaktiskt dilemma kan ha relationer med flera spänningar. De båda uttrycken är överlappande och befinner sig på en glidande skala där det inte är tydligt när en spänning går över i ett didaktiskt dilemma.

En initial förutsättning för mig att upptäcka spänningar var att jag kunde se på lärarnas undervisning ur ett verksamhetsteoretiskt perspektiv. Utifrån Leontievs beskrivningar av verksamhetens beståndsdelar och relationer och med hjälp av Engeströms verksamhetssystem och hur detta påverkas av andra verksamhetssystem, kunde komplexiteten i den reflexiva undervisningen synliggöras. Under studiens preliminära analyser under datainsamlingen hjälpte verksamhetsteorin mig att få syn på och sortera data. Engeströms verksamhetsteori beskriver hur spänningar och motsättningar i och mellan verksamhetens delar och andra verksamheter kan driva en förändring. Analytiska verktyg utifrån Engeströms verksamhetssystem hjälpte till i analysen under Fas 1 för att urskilja och tematisera de spänningar som lärarna diskuterade.

När analysprocessen skulle fördjupas under studiens andra fas upplevde jag emellertid att analys med hjälp av Engeströms verksamhetssystem, med förutbestämda noder, inte erbjöd mig den detaljnivå kring didaktiska dilemman som jag eftersträvade. Istället kom studien att anamma ett kompletterande perspektiv genom att betrakta undervisningens helhet som ett dilemmatic space (Fransson \& Grannäs, 2013). Detta perspektiv kunde erbjuda mig ett större förklaringsvärde när de beskrivna spänningarna med deras inneboende didaktiska dilemman kunde analyseras kopplat till undervisningens specifika kontext och därmed förstås mer i detalj. Engeströms verksamhetssystem med sin schematiska uppbyggnad med olika avgränsade och fördefinierade delar var till hjälp för att få syn på spänningar. Dess lätt rigida och statiska uppbyggnad gjorde dock att delar av komplexiteten i den reflexiva undervisningen och relationerna mellan olika didaktiska dilemman inte kom fram. Med hjälp av det 
mer flexibla perspektivet dilemmatic space kunde detta analyseras och beskrivas på ett tydligare vis.

\section{Komparativ didaktik}

En stor del av studien handlar om att studera de svenska lärarnas förgivettagna positioner i olika didaktiska dilemman. Vidare handlar det om att reflektera över de olika positionernas möjligheter och negativa konsekvenser för elevernas utveckling och lärande. Almqvist (2008) menar att lärare då och då behöver synliggöra och problematisera det som valts ut och tagits för givet i undervisningen. Detta kan ses som grunden för komparativ didaktik, som handlar om att det förgivettagna synliggöras och att man därigenom får kunskaper om undervisning och lärande (Ligozat, Amade-Escot \& Östman, 2015). Det kan handla om att man jämför undervisning inom samma ämnen, mellan ämnen eller att man studerar likheter och skillnader på undervisning i olika sociokulturella kontexter. Detta kan leda till att man kan beskriva undervisningen mer exakt och därmed generera ny kunskap (Almqvist, 2015). Framväxten av komparativ didaktik kan spåras till den franska didaktiktraditionen vilken bidrar med kunskaper om olika sätta att bedriva undervisning kring ett givet ämnesinnehåll (Caillot, 2007).

För att studera vad som inkluderas och exkluderas i undervisningspraktiker beskriver Almqvist $(2008,2014)$ ansatsen privilegieringsanalys. Denna tar sin utgångspunkt i den visshet och de förgivettaganden som deltagarna har och som man lärt sig handla efter. Kring dessa sedvänjor har normer och regler utvecklas för att reglera vad som är rimligt att göra. I undervisningssammanhang kan det enligt Almqvist (2014) handla om vilka didaktiska val och positioneringar i didaktiska dilemman som ses som rimliga och relevanta att göra i en viss undervisningssituation. Han sammanfattar att en privilegieringsanalys fokuserar på hur mening skapas i handling, men också på vad som utesluts i undervisningspraktiken.

En privilegieringsanalys sker i två steg. Sett ur ett didaktiskt perspektiv handlar det om att i ett första steg göra en beskrivning av hur lärare handlar i en given undervisningspraktik (Almqvist 2008, 
2014). Väsentligt är att förstå hur det blir rimligt för lärarna att göra de didaktiska val de gör utifrån de omständigheter som råder $\mathrm{i}$ undervisningssituationen. I ett andra steg handlar det om att jämföra denna beskrivning med alternativa beskrivningar i syfte att kunna föra en kritisk diskussion om relationen mellan de förgivettagna didaktiska valen och alternativa didaktiska val. I linje med grundtankarna i komparativ didaktik kan den alternativa beskrivningen vara att göra jämförelser mellan olika sociokulturella kontexter, men även mellan olika ämnestraditioner. Genom komparationer mellan lärare från olika länder kan dessa relationer och lärandets institutionella och sociokulturella villkor lyftas fram. Detta klargörande är en grund för att tillsammans med lärare utveckla relevant och effektivt fortbildningsmaterial. Ibland behövs det förgivettagna ifrågasättas och läraren behöver aktivt välja en annan väg i sin praktik. För att göra detta påpekar Almqvist (2014) att läraren både behöver få syn på det som är förgivettaget och ha kunskaper om de normer, regler och vanor som gäller i undervisningspraktiken och även få tillgång till alternativ.

Med inspiration från komparativ didaktik kom studien att delas upp $i$ tre faser. I den första handlade om att sammanställa en beskrivning av hur de olika lärargrupperna agerar och positionerar sig i den reflexiva undervisningen. I en andra fas av studien jämfördes de svenska lärarnas beskrivning med de alternativa beskrivningarna från övriga lärargrupper i en kritisk diskussion om de förgivettagna positionerna och alternativa positioner. I en avslutande tredje fas sammanställdes kunskaper om didaktiska dilemman och olika positioner till ett diskussionsverktyg för användning vid utveckling av reflexiv undervisning.

\section{Fokusgrupper och deltagande observationer}

Det empiriska materialet i studien kommer från fokusgruppsintervjuer med deltagarna gjorda under projektet samt fältanteckningarna gjorda i samband med deltagande observationer under de temadagar då respektive skolor arbetade med den femte och sista arbetsuppgiften inom projektet. Genom att kombinera data på dessa 
två datainsamlingsmetoder kan man få koncentrerad insikt i hur deltagarna tänker (Morgan, 1997). Som komplement finns även fältanteckningar gjorda vid andra tillfällen när jag följde arbetet inom projektet. Eftersom jag spenderade mycket tid med de deltagande lärarna under möten, utbyten och andra besök innebär det att ovannämnda dokumenterade data också kompletteras med en stor mängd odokumenterad empiri, som jag ofrånkomligen samlat på mig under tiden med studiens lärare. I min analys görs tolkningar av dokumenterade data därför i relation till det specifika sammanhanget där empirin inhämtades. Därmed blir analysen oundvikligen partisk, då jag använder mina egna erfarenheter och egna konceptuella verktyg för att tolka vad som händer. För att en läsare ändå ska kunna granska studiens data är ambitionen att på ett pålitligt och begripligt sätt beskriva hur jag gått tillväga för att samla in och analysera data, samt även beskriva det sammanhang där empirin samlades in.

Att använda fokuserade gruppintervjuer som forskningsmetod skapar möjlighet att studera människors kunskaper, föreställningar, attityder och värderingar kring ett givet ämne (Wibeck, 2010). I diskussionerna i fokusgruppen kan deltagarna antingen hålla med eller ge uttryck för avvikande åsikter och därmed skapas möjligheter för deltagarna att reflektera inte bara över sina egna uppfattningar, utan även över andras (Kvale \& Brinkmann, 2009). Både jag i min forskarroll och skolorna i sitt utvecklingsarbete delade ett intresse av att upptäcka didaktiska dilemman i verksamhetssystemen. Samtidigt behövde jag hela tiden vara uppmärksam på att det fanns risk att deltagare, inte minst i fokusgruppsdiskussioner, inte helt beskrev situationerna som personen egentligen upplevde dem (Wibeck, 2010). Med återkommande fokusgruppsdiskussioner av olika art samt deltagande observationer öppnades det upp för triangulering, vilket ökar studiens trovärdighet (Robson, 2011).

Wibeck (2010) menar att fokusgrupper är en bra metod att använda när man vill undersöka hur olika människor handlar och vilket motiv de anger för sitt handlande. I diskussionerna jämför deltagarna 
sina egna handlingar med andras och försöker förstå de andra deltagarnas val. Medlemmarna ställer frågor till varandra och detta kan hjälpa forskaren att upptäcka saker som denne inte hade tänkt på. Wibeck menar att fokusgrupper är en lämplig metod när det finns olikheter mellan människor och dessa olikheter vill förstås.

I studien skapades både fokusgrupper med deltagare från alla medverkande skolor och fokusgrupper med endast deltagare från en och samma skola. De internationellt blandade fokusgrupperna kan betraktas som en homogen grupp men med tillräcklig variation för att det ska finnas olikheter (Krueger \& Casey, 2015). De bestod av lärare som alla hade arbetat med en reflexiv undervisning, men det fanns en variation genom att dessa kom från olika länder och även undervisade i olika ämnen. Med denna gruppsammansättning kan skillnaderna göra att deltagarna sätter sina egna åsikter i relation till andra perspektiv och då utvecklar sina egna idéer i samband med intervjutillfället (Wibeck, 2010). Wibeck anser att det kan vara givande att kombinera fokusgrupper med större variation med fokusgrupper med mindre variation mellan deltagarna. Därigenom kan data från olika sorters fokusgrupper komplettera varandra. I studien genomfördes även nationella fokusgruppsintervjuer och i en avslutande sådan med studiens svenska lärare kunde dessa tillsammans reflektera kring skillnaderna i handlingar och motiv mellan lärargrupperna i studien.

Deltagande observationer är en metod för att samla in data vid fältstudier där man kombinerar intervjuer med både direkt deltagande i praktiken och mer iakttagande observation där en initial analys påbörjas redan under observationsprocessen. Samtidigt som man får möjlighet att observera från deltagarnas perspektiv innebär det oundvikligen också att man även påverkar det man observerar (Flick, 2009). Tack vare djupen i fallstudier kan de framgångsrika då dessa undersöker processer och fenomen i dess verkliga miljö (Gomm, Hammersley \& Foster, 2000). Med hjälp av kontinuerliga fokusgruppsintervjuer och deltagande observationer under arbetet på skolorna i studien, samt även i samband med Erasmus+ partnerskapets elevutbyten, skapades förutsättningar för detta. 
Eftersom studiens design var flexibel fick preliminära analyser efter hand komma att styra innehållet för de nästföljande fokusgruppsintervjuerna, samt även den följande datainsamlingen. Datainsamlingen och analysprocessen genomfördes i tre faser och dessa beskrivs fas för fas mer i detalj i kommande kapitel. I dessa kapitel beskriver jag först datainsamlingsprocessen och därefter analysen följd av en längre del där jag redovisar och diskuterar resultaten för respektive del. Givetvis finns inga helt skarpa gränser mellan faserna och de var tidsmässigt olika långa och överlappar dessutom varandra.

Fyrfältsdiagram som visuell beskrivningsmodell

Under den avslutande fokusgruppsintervjun med studiens svenska lärare användes fyrfältsdiagram för att illustrera de olika lärargruppernas positioneringar i olika didaktiska dilemman. Det gynnsamma utfallet av detta gjorde att fyrfältsdiagram också fick bli grunden i den didaktiska modell som studien ville utveckla. Fyrfältsdiagram är ett välanvänt sätt inom samhällsvetenskapen för att illustrera möjliga scenarier när man har två olika faktorer som spelar in. Diagrammens utformning med sina fyra variationer underlättar reflektion kring alternativen i de olika kvadranterna och är ett verktyg för att värdera olika beslutsalternativ.

Fyrfältsdiagrammen i denna studie är empiriskt framtagna utan någon specifik förlaga. När olika didaktiska dilemman trädde fram under analysprocessen provade jag att kombinera dem parvis i fyrfältsdiagram genom att dilemman med nära relationer kombinerades. I litteraturstudier för att få en teoretisk underbyggnad till dessa fann jag att fyrfältsdiagram använts tidigare på liknande vis. Healey (2005) skapade ett fyrfältsdiagram för att beskriva och analysera spänningen inom forskarutbildningen. Med utgångspunkt i Healeys fyrfältsdiagram har Bränberg och Holmgren (2015) utvecklat en modell för analys av och som grund för diskussioner kring dessa aspekter på ingenjörsutbildningar. 
För att illustrera olika perspektiv på hur en läroplan fungerar använde Reid (2006) ett fyrfältsdiagram som han benämnde läroplanskarta. I diagrammet finns fyra extrema idealtyper som var och en representerade olika läroplanstraditioner i kvadranterna och Reid argumenterade för en deliberativ hållning där man vägde de fyra extrema hållningarnas innehåll mot varandra och betraktade det som dilemman. Reid valde själv att inte publicera fyrfältsdiagrammet, men illustrationen publicerades av Null (2011) i en något bearbetad version. Reid (2006) menar att det inte finns endast ett rätt svar men genom diskussion och reflektion går det att hitta lösningar på aktuella problem.

Även andra har använt sig av fyrfältsdiagram för att illustrera dilemman inom denna form av undervisning, såsom Miller-Lane, Denton och May (2006) som använder fyrfältsdiagram för att analysera olika aspekter av lärarens objektivitet och neutralitet under diskussioner kring kontroversiella ämnen. Amnå m.fl. (2010) beskriver didaktiska dilemman rörande lärares acceptans av kontroverser $\mathrm{i}$ klassrummet och valet av kommunikativ strategi i ett fyrfältsdiagram och en liknande modell använder Jensen och Schnack (2006) för att diskutera skillnader mellan en aktivitetsinriktad och en handlingsinriktad undervisning i relation till elevers inflytande på undervisningen. I andra sammanhang har Engeström och Sannino (2010) $i$ en verksamhetsteoretisk studie illustrerat dilemman rörande valfrihet och rätt till hemvård för alla på detta sätt, och Haavisto (2002) som illustrerar dilemman som rör muntliga framställningar vid finska domstolsförhandlingar med fyrfältsdiagram.

Fyrfältsdiagrammen i denna licentiatuppsats är gjorda för att användas i det specifika sammanhang som undervisning utifrån samhällsdilemman utgör. Studiens fyrfältsdiagram bidrar både till teori och praktik genom att belysa syfteskomplexiteten i denna form av undervisning där det finns olika handlingsalternativ att välja beroende på vilket huvudsyfte man har. Studien bidrar även genom att det finns flera relaterande fyrfältsdiagram i en sekvens i det diskussions- och reflektionsverktyg som studien presenterar. 


\section{Studiens tre faser}

I detta avsnitt kommer studiens metodiska upplägg kortfattat beskrivas, vilket även illustreras grafiskt med figur 7 nedan. Mer ingående beskrivningar av processen i studiens tre faser görs i de kommande tre kapitlen.

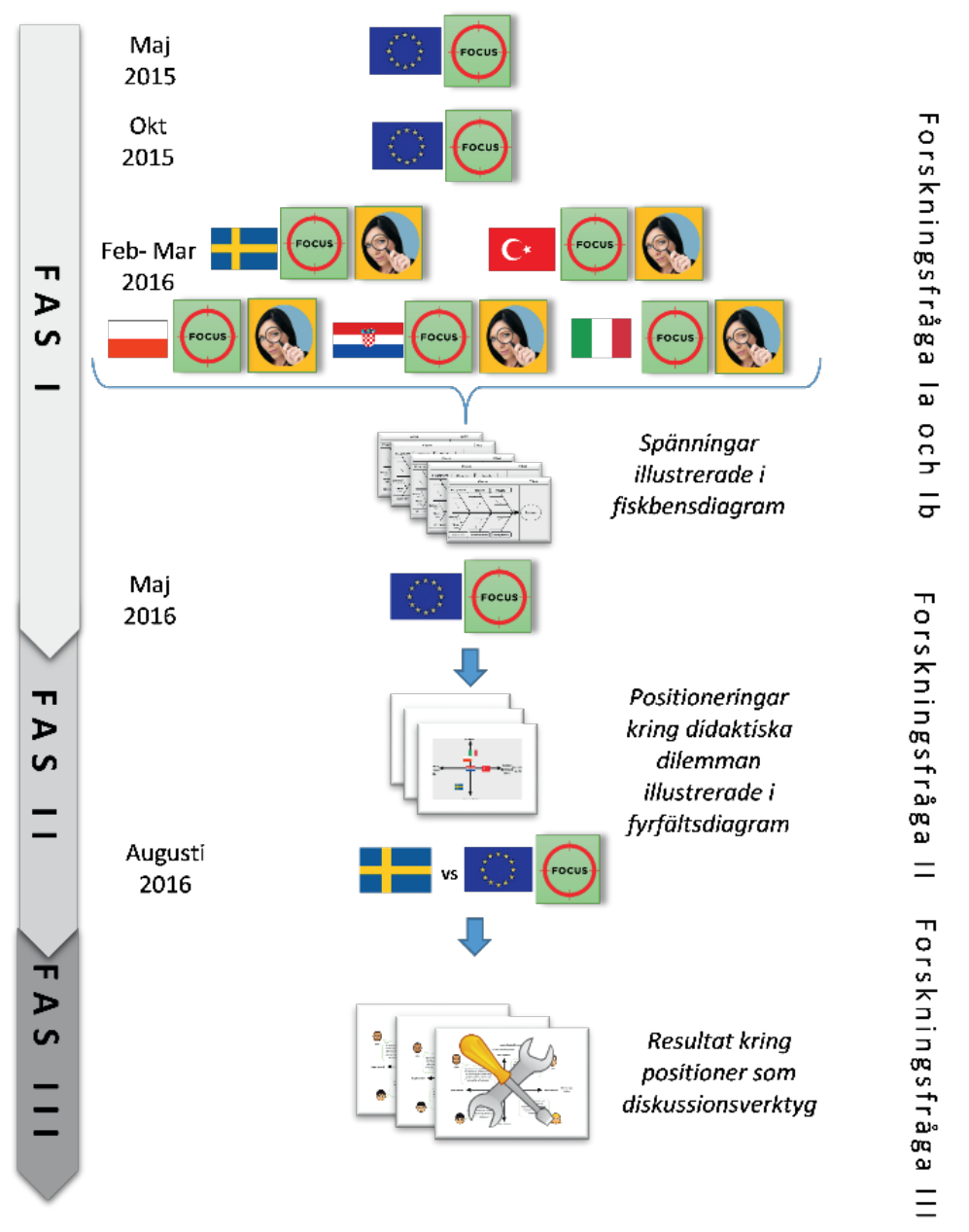

Figur 7. Schematisk skiss över studiens upplägg. 


\section{Studiens första fas}

Den första fasen är tidsmässigt parallell med Erasmus+ partnerskapet. Skolorna arbetade inom detta i tre cykler med undervisningsmodellen och de olika kontroversiella och komplexa frågor som ingick i denna. Erasmus+ partnerskapets första cykel avslutades med ett utbyte i maj 2015 och i samband med detta genomfördes de första fokusgruppsintervjuerna och dessa följdes sedan upp med nya fokusgruppsintervjuer i samband med utbytet i slutet av andra cykeln. Under partnerskapets tredje och avslutande arbetscykel genomfördes även deltagande observationer på alla skolorna. I samband med det genomförde skolorna en temadag och arbetade under denna med kontroversiella frågor rörande bioteknik och framtida användning av robotar i samhället. I samband med dessa besök genomfördes även fokusgruppsintervjuer med respektive skolas lärare. Fokus var på att utröna spänningar och didaktiska dilemman som lärarna upplevt i samband med den reflexiva undervisningen.

Analysen av data insamlad genom fokusgruppsintervjuer och deltagande observationer under skolornas arbete med Erasmus+ partnerskapet svarade mot forskningsfrågorna I a och I b. Dessa avsåg vilka olika spänningar som deltagarna upplever när de arbetar med den reflexiva undervisningen och vilka olika positioner som lärargrupperna intog i de didaktiska dilemman som spänningarna gav upphov till. Ett urval gjordes sedan där de didaktiska dilemman som bedömdes som mest väsentliga för en svensk kontext valdes ut.

\section{Studiens andra fas}

För att skapa ett diskussionsunderlag för en uppföljande fokusgruppsintervju med studiens svenska deltagare illustrerades resultaten från Fas I med fyrfältsdiagram. Detta gjordes genom att kombinera två didaktiska dilemman som stod i nära relation till varandra och markera respektive lärargrupps olika positioner i dessa fyrfältsdiagram. Fokusgruppen tog därför sin utgångspunkt dels från min analys av data från den första fasen, illustrerad i fyrfältsdiagrammen, dels de svenska lärarnas egna erfarenheter från samarbetet inom Erasmus+ partnerskapet. 
I augusti 2016 arrangerades en fokusgruppsintervju med de medverkande svenska lärarna. Denna fokusgruppsintervju varade i två timmar och under denna behandlades fyrfältsdiagrammen ett i sänder med en diskussion kring varje. De didaktiska dilemmana hade valts så att de dilemman där det fanns tydligast kontraster ur ett svenskt perspektiv prioriterades och till varje fyrfältsdiagram fanns en eller ett par diskussionsfrågor $\mathrm{i}$ en frågeguide som inledde diskussionen kring dilemmana i fyrfältsdiagrammet. De svenska lärarna diskuterade de positioner som de själv intagit $\mathrm{i}$ arbetet med den reflexiva undervisningen under studien, men reflekterade även kring positioner som de andra lärargrupperna intog i de olika didaktiska dilemmana. Det gällde dessutom även alternativa positioner som de svenska lärarna själv intagit i andra former av undervisning. Studiens tanke var inte att hitta didaktiska dilemman och att beskriva entydiga svenska positioner i dessa. Genom att betrakta den reflexiva undervisningen som ingående i ett dilemmatic space finns inga entydigt rätta didaktiska val att göra i dessa situationer utan i undervisningens komplexitet kan olika val både erbjuda möjligheter och medföra negativa konsekvenser. Dessutom kan en position i ett didaktiskt dilemma påverka positioner i andra dilemman och läraren i sin tur kan även positioneras av andra aktörer eller av normer och lagar. För att hantera en förändrad undervisning behöver läraren först identifiera de didaktiska dilemmana och vilka olika följder som de olika valmöjligheterna har. För att göra detta måste läraren ställa den didaktiska Varför-frågan och bestämma vilket huvudsyfte som undervisningsaktiviteten har.

\section{Studiens tredje fas}

Ur den första fasens olika spänningar fördjupades i den andra fasen de som bedömdes vara mer relevanta ur en svensk kontext. Här byggdes kunskaper upp om några didaktiska dilemman som man kan ställas inför i en reflexiv undervisning och om de möjligheter och negativa konsekvenser som olika positioner i de olika didaktiska dilemmana kan innebära.

Ur andra fasens slutsatser skapades ett diskussions- och reflektionsverktyg tänkt för lärarstuderande och yrkesverksamma lärare och 
denna tredje fas är inriktad mot forskningsfråga III. Detta verktyg bygger på det diskussionsunderlag som användes under den avslutande fokusgruppsintervjun med den svenska lärargruppen i fas II. Inom ramen för denna licentiatuppsats fanns inte utrymme för att vidare testa detta verktyg utan det kommer att ske i form av framtida forsknings- och utvecklingsarbete, men själva modellen för verktyget stämdes av med de svenska lärarna.

\section{Studiens olika val}

Detta var en explorativ studie som inte hade en helt och hållet bestämt forskningsdesign där studiens utformning och dess forskningsfrågor kom att växa fram efter hand genom preliminära analyser av det empiriska materialet. Enligt Erickson (1998) ska förändringar under vägen inte ses som ett problem när det gäller kvalitativa studier likt denna. De ska snarare ses som en möjlighet och som tecken på väl genomförd analys då det visar att man gjort upptäckter som inte kunde förutsägas vid planeringen av studien.

Mina dubbla roller

Eftersom jag skapat den undervisningsmodell som de medverkande skolorna arbetade med, och även kontinuerligt arbetat med att justera denna i samarbete med praktikerna, har jag haft dubbla roller. Under analysen av hur de svenska lärarnas positioner i de didaktiska dilemmana kan kontrasteras mot de övrigas är jag som konstruktör av upplägget för elevuppgiften också en av de svenska lärarna, då denna är skriven utifrån min svenska skolkontext och beprövade erfarenhet. Den deltagande svenska skolan är vidare min före detta arbetsplats och deltagarna före detta kollegor. Under projektets gång har även personliga relationer byggts upp till övriga medverkande.

Herr och Andersen (2005) har tagit fram en skala från 1 till 6 som beskriver lärarens insiderposition i förhållande till den verksamhet som studeras där siffran 1 motsvarar en forskare som studerar sin egen praktik och siffran 6 en forskare som har en outsiderposition och studerar verksamheten helt från utsidan. Mellan extremerna finns mellanpositioner och på den sexgradiga skalan bedömer jag 
min roll i studien som att vara närmst position 4 vilken innebär att det finns en ömsesidig samverkan mellan insiders i form av lärarna och outsidern i form av mig som forskare. Herr och Andersen menar att denna position kanske är den som ger bäst förutsättningar för ett demokratiskt tillvägagångssätt av en studie, men de menar samtidigt att reflexivitet och uppriktighet är avgörande, eftersom forskaren både kan inta en insiderroll och en outsiderroll under studien.

Farahani (2011) menar att en insider kan få svar som en outsider inte kan få, eftersom den känner till bakgrund och kontext. I denna studie kan detta ta sig uttryck i att jag har kunnat följa upp svar och uttalanden från de svenska lärarnas sida med fördjupande följdfrågor i stunden genom min insiderkunskap. Samtidigt finns det en risk att en forskare som är insider inte får samma uppriktiga svar om den som intervjuas har förutbestämd inställning till personen när denne är en insider. Precis som forskaren positionerar objektet blir forskaren positionerad. Farahani menar därför att man som forskare måste vara självreflekterande och se sina egna olika roller och vara medveten om att ens egen historia och egna erfarenheter påverkar forskningen.

\section{Etiska överväganden}

Det finns en inneboende konflikt för samhällsvetenskaplig forskning mellan kraven på offentlighet, öppenhet och insyn och kravet på skydd så att integritetskänsliga uppgifter om individer och grupper som kan komma fram i undersökningar inte kommer ut. Inom forskning handlar det om att på ett rimligt sätt väga olika legitima intressen mot varandra (Vetenskapsrådet, 2011). I didaktiska studier är det vanligt att anonymisera deltagare och medverkande skolor och åtgärder vidtas så att inte någon ska identifieras. Vad gäller detta fall var det en studie av ett befintligt internationellt samarbetsprojekt mellan skolor i fem olika länder. I och med att detta projekt var offentligt, och dessutom med en explicit förväntan på sig att sprida sina erfarenheter, skulle det bli svårt att utlova skolorna anonymitet. Enbart med hjälp av antalet deltagande länder och sammansättningen skulle samarbetsprojektet relativt enkelt kunna identifieras 
genom en webbsökning och därigenom namnge medverkande skolor. Jag skulle förvisso kunna välja att inte avslöja vilka länder som deltog i studien, men eftersom varje lands specifika skolkontext spelade stor roll i studien i samband med att de didaktiska dilemmana som identifierats diskuterades i studiens inledande faser, skulle det vara problematiskt. Larsson (2005) menar att det kan uppstå en konflikt mellan validitet och etik om man döljer alltför mycket, för i så fall kan belägg och resultat som läggs fram vara diffusa och det blir svårt att belägga slutsatser med full tydlighet.

Eftersom min studie studerar och diskuterar didaktiska dilemma i lärarnas skolvardag på en generell nivå gjordes bedömningen att det inte rörde sig om några integritetskänsliga uppgifter som behandlades, även om diskussionerna delvis berörde politiska frågor. Allt deltagande i studien byggde på frivillighet och alla deltagare erbjöds möjlighet att antingen delta anonymt eller med sitt riktiga namn. De medverkande gjorde detta val på en skriftlig samtyckesblankett på vilken de även informerades om studiens inriktning och att de när de ville kunde välja att avbryta sitt deltagande i studien. Varje rektor tillfrågades också om att ge samtycke för att använda skolans riktiga namn eller inte. Samtliga medverkande och samtliga skolor gav skriftligt samtycken till att medverka i studien under riktiga namn.

Även om deltagarna gett sin tillåtelse att medverka med riktiga namn hanterades datamaterialet ändå med stor eftertanke och försiktighet och de medverkande fick ta del av både preliminära resultat och de citat som jag använder mig av. I denna licentiatuppsats har jag slutligen ändå valt att använda fingerade namn på deltagarna för att anonymisera de enskilda lärarna i görligaste mån, främst med tanke på lärarna i de utländska skolorna. Troligtvis är det inga av uttalandena som kan tas illa upp av någon berörd part, men eftersom jag inte har tillräckliga kunskaper för att bedöma om några uttalanden skulle kunna skapa problem för en enskild lärare nu eller i framtiden, gjorde jag detta val. 


\section{Kvaliteter i metoden}

Genom mina dubbla roller kom jag nära deltagarna i studien. Därmed kunde jag på ett fördjupat vis ta del av de spänningar och didaktiska dilemman som uppstod när man arbetade med en reflexiv undervisning. Då studien sträckte sig under längre tid och genom att jag delvis fick en insider-roll fick jag ett innehållsrikt datamaterial att arbeta med. Samtidigt innebar denna närhet till det som studerades både en risk att jag själv påverkade resultaten och att mina egna tolkningar av resultaten påverkades. I en studie med deltagande observation finns det en balansakt mellan närhet och distans. Genom att reflektera över min egen roll och även kritiskt granska förgivettaganden i den undervisningsmodell jag gjort och relatera preliminära resultat till tidigare forskning har jag försökt skapa en nödvändig distans. I fokusgruppsintervjuer och andra diskussioner var jag noga med att inte lägga in egna värderingar. I samband med mina deltagande observationer diskuterade jag dessutom den reflexiva undervisningen och dess spänningar både med elever och med skolledningen för att få en kontext till lärarnas beskrivningar.

Ett annat argument som kan anföras mot giltigheten i resultaten var att det endast var en svensk skola i analysen av spänningar och didaktiska dilemman som kunde uppstå i en reflexiv undervisning. Studien ämnade emellertid inte att fastlägga alla didaktiska dilemman som kan finnas och inte heller föreskriva en riktig lösning gällande dessa. Med hjälp av deltagarna på den svenska skolan och deras spegling av egna förgivettagna positioner erbjöds jag ett tillräckligt datamaterial för att kunna relatera detta till befintlig teori.

Det aktiva stöd som jag erbjöd skolorna genom undervisningsmodellen innebar att jag levde upp till det dubbla uppdrag man har att även stödja lärarna när man bedriver forskning om förändringsprocesser (Engeström, 1987; Chaiklin, Hedegaard \& Juul Jensen, 1999; Roth \& Tobin, 2002). I de återkommande fokusgruppsdiskussionerna beskrev lärarna de spänningar med olika didaktiska dilemman som fanns i den reflexiva undervisningen. Genom att de var återkommande gav det möjlighet att föra tillbaka preliminära tolkningar 
till lärarna och på så vis fördjupa och bredda resultaten. En avgörande del i forskningsdesignen var även sammansättningen av skolor från olika kulturella kontexter. Genom studiens komparativa, longitudinella och iterativa upplägg gavs möjlighet att få syn på förgivettaganden som inte enkelt upptäcks vid en första eller andra anblick.

Kvaliteter i framställningen som helhet

Larsson (2005) har gjort en sammanställning av kvalitetskriterier för slutprodukter i kvalitativ forskning där han delar in kriterierna under tre rubriker. De olika kriterierna ska inte betraktas som absoluta utan alla kriterier är inte alltid tillämpliga och dessutom kan vissa ibland betraktas som alternativa. Det första som Larsson beskriver gäller kvaliteter i framställningen som helhet. Det ska finnas en perspektivmedvetenhet, en intern logik samt ett etiskt värde i framställningen. Vad gäller perspektivmedvetenheten har jag beskrivit tidigare forskning, den teori som hjälpt mig tolka och analysera samt relaterat till min egen förförståelse. Den interna logiken handlar om att forskningsfrågor, ens egna antaganden om forskningens objekt, datainsamling och analys ska harmonisera. Eftersom jag anpassat både frågor, insamling och analysprocessen efter hand har jag inte varit bunden till en förutbestämd metod. Samtidigt har de val som gjorts relaterats till befintlig teori. I diskussioner om resultaten har jag relaterat dessa till mina antaganden från tidigare forskning och om reflexiv undervisning. Det tredje kriteriet som Larson anger gäller etiskt värde. Det gäller inte bara etiska överväganden gentemot deltagarna utan även vetenskaplig hederlighet. Deltagarna i studien var medvetna från början om att studien syftade till att belysa förgivettaganden i deras egen praktik och om att studien skulle redovisa dessa. Förgivettagna positioner hos både deltagare och forskare har därför redovisats på ett öppet och hederligt sätt. Studien har inte haft som syfte att peka ut något som "rätt eller fel" eller "bättre eller sämre" utan istället har det handlat om att belysa olika didaktiska vals möjligheter och potentiella konsekvenser. Därför har det inte funnits något incitament att förtiga eller förvanska några data. 
Kvaliteten i resultaten

Vad gäller kriterier för att säkerställa god kvalitet i resultaten för en kvalitativ studie lägger Larsson (2005) fram tre kvalitetskriterier. Det ska finnas en innebördrikedom genom att det ska finnas en fyllig beskrivning som samtidigt fångar det väsentliga. Innebördsrikedomen ökar värdet av tolkningarna genom att fler nyanser lyfts fram och därmed kan tolkningen bli mer precis. Samtidigt som det är en fyllig beskrivning ska det finnas en tydlig struktur i presentationen och de huvudsakliga resultaten ska vara tydliga för läsaren. Det tredje kvalitetskriteriet som gäller resultaten är teoritillskott och det kan delvis tala för sig självt. Samtidigt kan man bidra med ny kunskap på en rad olika vis och det är ibland inte helt enkelt att entydigt avgöra om tillskottet är av avgörande art eller endast marginellt.

I min studie valde jag att beskriva resultaten från studiens första fas genom att presentera alla de spänningar som lärarna på skolor i studien upplevde. Kring de spänningar som bedömdes vara mer relevanta ur en svensk skolkontext gjordes sedan en fylligare beskrivning kring olika positioner som lärarna på respektive skola intog. Under andra fasen valde jag att fokusera på de svenska lärarnas diskussioner om sina egna didaktiska val när dessa relaterades till alternativa positioner i didaktiska dilemman. Kunskaper kring dessa positioners möjligheter och potentiella konsekvenser blev sedan grunden för fyrfältsdiagrammen under den tredje fasen. Här diskuterades implikationerna av de didaktiska dilemmanas olika positioner och relationer mer ingående. Det finns en spänning mellan innebördsrikedom och struktur (Larsson, 2005) där fyllighet kan innebära en komplexitet som göra att den tydliga strukturen och den röda tråden kan vara svår att utskilja för läsaren. I detta fall har det varit en stor utmaning $\mathrm{i}$ och med att studien varit rik på data och genomförts i flera steg.

Vad beträffar studiens eventuella teoritillskott behöver man först reflektera kring om ett teoritillskott främst ska användas av forskarsamhället eller av praktiken. Detta är en i högsta grad praktiknära studie som också vill ge tillbaka teori till just praktiken, främst i form av diskussions- och reflektionsverktyget. För en praktiker kan 
detta vara ett teoritillskott som kan hjälpa till att orientera läraren i en undervisning med utgångspunkt ifrån samhällsdilemman. Huruvida studien tillför ny och avgörande teori till forskarsamhället är det en mer öppen fråga. Denna empiriska studie har emellertid bidragit till att sammanställa och belysa den komplexitet som finns när det gäller att undervisa kring samhällsdilemman i skolan.

\section{Validitetskriterier}

Gränsen mellan kvaliteter i framställningen i stort och validiteten hos resultaten är inte helt tydlig utan flytande. Beskrivningen och presentationen av resultaten är en avgörande del i kvalitativa studiers validitet. Larsson (2005) försöker ändå dra en gräns mellan dessa delar och presentera fem kriterier som kan säkerställa en studies tillförlitlighet. Diskurskriteriet handlar om att de påståenden och argument som läggs fram håller när de ställs mot alla andra alternativa påstånden och argument $\mathrm{i}$ ämnet. Ett andra validitetskriterium som Larsson beskriver är att det ska finnas ett heuristiskt värde genom att den som läser framställningen övertygas om att den fått en ökad förståelse om människan och välden vi lever i. Det ska även finnas en överensstämmelse mellan verklighet och tolkning genom att det finns en empirisk förankring av tolkningarna. Med konsistens menar Larsson att det finns hög kvalitet i tolkningarna som görs så att det endast finns få motsägelser mellan helhetstolkningen och enskilda data. Avslutningsvis finns det pragmatiska kriteriet som innebär att studiens resultat ska ha någon praktisk nytta eller betydelse i verkligheten.

Om poängen med denna studie skulle varit att entydigt beskriva vilka didaktiska val och positioneringar svenska lärare generellt gör $i$ en reflexiv undervisning skulle det finnas en hel del att diskutera kring validitetskriterierna. $\mathrm{Nu}$ ämnade emellertid inte studien att göra detta, utan istället var meningen att belysa olika möjliga didaktiska dilemman och olika positioners potentiella möjligheter och konsekvenser. Fokus för detta låg på en svensk skolkontext där jag med hjälp av studiens svenska lärares reflektioner fick syn på både förgivettagna positioner och alternativa sådana. Detta gjordes i spegling mot de utländska kollegornas positioneringar och utifrån 
dessa diskussioner byggdes det upp empiriska kunskaper om de didaktiska dilemmana. Genom att koppla de svenska lärarnas uttalanden med tidigare forskning kunde kunskaperna fördjupas. Att just belysa den komplexitet som finns i undervisningen generellt, och i den reflexiva mer specifikt, är studiens främsta heuristiska värde. Studien vill bidra till att medvetengöra praktiker om att undervisningens olika syften ibland skapar didaktiska dilemman vilka behöver diskuteras och reflekteras över så att undervisningens handlingar och operationer utförs i relation till rätt syfte. Genom att som implikation av studiens resultat skapa ett underlag för ett reflektions- och diskussionsverktyg kan studien därmed uppfylla det pragmatiska kriteriet.

Vad gäller diskurskriteriet omfamnar studiens resultat tanken att det i diskursen finns flera svar som alla kan vara sanna. Under studien följde jag lärarna under lång tid och hade ett antal fokusgruppsintervjuer vid olika tillfällen där preliminära tolkningar återfördes till deltagarna. Denna datainsamling kompletterades med deltagande observationer vilket innebar att jag kunde få en triangulering av resultaten. Detta skapade underlag för en empirisk förankring av tolkningarna. Konsistenskriteriets motsägelsefria helhetstanke kan i vissa fall stå $i$ ett spänningsförhållande till den empiriska förankringen (Larsson, 2005), vilket inte minst belyses av denna studie. De resultat som presenteras här handlar inte om att presentera en enhetlig helhet utan snarare om att belysa en komplext sammansatt verklighet där olika positioner i olika dilemman påverkar varandra. Istället för att visa på att "så här är det" pekar denna studie på att "det kan antingen vara si eller det kan vara så". Beroende på vilket didaktiskt val man gör som lärare finns det både möjligheter och negativa konsekvenser. Dessa behöver man som lärare ständigt vara medveten om i förväg och även ha en handlingsrepertoar för, så att man i undervisningens komplexa vardag kan fatta snabba och så välfungerande beslut som möjligt. Varken konsistens- och diskurskriteriet uppfyller licentiatuppsatsen till fullo, men som Larsson påpekar kan inte alla kriterier vara möjliga att tillämpa på all kvalitativ forskning. 


\section{FAS I - SPÄNNINGAR OCH POSIT- IONERINGAR}

Denna fas sträcker sig över själva Erasmus+ partnerskapet med tre elevutbyten samt mina deltagande observationer på skolorna. I samband med fokusgruppsintervjuerna vid de två första elevutbytena diskuteras de olika undervisningsverksamheterna historicitet och vilket syfte man kan se med den reflexiva undervisning som bedrevs inom Erasmus+ partnerskapet. Lärarna fick även reflektera kring den undervisning som de skulle vilja bedriva i relation till skolans gängse undervisning. I samband med de deltagande observationerna och partnerskapets sista elevutbyte kom fokus att hamna på att diskutera de olika didaktiska dilemman som deltagarna och jag identifierat under vägen.

\section{Datainsamling under fas I}

Fokusgruppsintervjuer genomfördes i samband med de tre internationella utbytena och vid varje träff hölls dels en fokusgruppsdiskussion med de fem lärare som är koordinatorer för respektive skola och dels en fokusgruppsdiskussion med ett urval av övriga involverade i projektet. Det var därför blandat med deltagare från alla skolor och med lärare som undervisar i naturvetenskap, teknik, samhällsvetenskap och språk samt i något fall även skolledare. Vid dessa fokusgruppsdiskussioner kunde det vara mer än en deltagare från varje land vilket gjorde att det i dessa intervjuer var närmare tio personer som deltog.

Fokusgruppsintervjuerna i samband med de två första elevutbytena berörde olika teman där ungefär samma frågeställningar togs upp i de parallella grupperna. Intervjuerna var semistrukturerade och följde en frågeguide och intervjuerna varade genomgående ungefär en timme. 
Vid första elevutbytet i maj 2015 utgick fokusgruppsintervjuerna från vilka förutsättningar skolan i stort och lärarna mer specifikt hade för att genomföra en undervisning som förbereder eleverna för ett liv i ett framtida samhälle. Vid genomförandet av dessa två fokusgruppsintervjuer hade skolorna arbetat med två av de fem delarna av elevuppgiften. Utmaningar i arbetet med den reflexiva undervisningen vävdes därför in i diskussionerna, även om en del av frågorna hade en generell karaktär.

I samband med detta elevutbyte, såväl som övriga, observerade jag även de förhandlingar mellan elever från olika länder som utgjorde avslutningen i elevernas arbete. Jag deltog även i andra aktiviteter under partnerskapets elevutbyte och hade därmed möjlighet till informella samtal med deltagarna vilket gjorde att jag fick en fördjupad förståelse för det deltagarna uttryckt under fokusgruppsintervjuerna vilket hjälpte mig att formulera diskussionsfrågor inför nästa elevutbyte. Dessutom hade jag en möjlighet att under utbytet stötta deltagarna med den teoretiska förståelsen av undervisningsmodellen och även detta innebar möjligheter för deltagarna att reflektera över sin egen undervisning utifrån jämförelse med de övrigas beskrivningar.

Vid Erasmus+ partnerskapets andra elevutbyte i oktober 2015 genomförde jag fokusgruppsintervjuer på motsvarande sätt med en grupp bestående av koordinatorerna samt en bestående av övriga lärare. De som var koordinatorer bibehöll sin roll under hela Erasmus+ partnerskapet vilket innebar att denna gruppkonstellation hölls intakt hela tiden. Vad gäller den andra gruppen skiftade deltagarna, dels beroende på att alla inte var med på samtliga elevutbyte, dels på att det var lättare för den skolan som arrangerande det aktuella elevutbytet att delta med fler lärare. Under fokusgruppsintervjuerna inspirerades frågeguiden av Engeströms verksamhetssystem som fungerade endast som en ram för mina frågor. Denna gång riktades frågorna mer konkret in på olika didaktiska dilemman som visat sig i form av spänningar mellan delarna i de olika skolornas verksamhetssystem under arbetet med den reflexiva undervisningen. 
Det kan vara på sin plats att påminna om att förutom att fokusgrupperna var ett tillfälle för mig att samla data, hade dessa även avsikten att stödja lärarna i deras förändringsprocess. I diskussionerna togs spänningar och didaktiska dilemman upp och de positioner som respektive skolas lärare intog beskrevs. Detta fungerade som en spegel för övriga lärare för att reflektera över sina egna positioneringar i olika didaktiska dilemman och bli uppmärksammade på vad som är förgivettaget i den egna praktiken.

I den tredje och sista cykeln av Erasmus+ partnerskapet arbetade skolorna med det ämnesområde om samhällsdilemman rörande framtida teknik med inriktning på robotik och bioteknik som beskrivits tidigare. I samband med detta genomförde jag deltagande observationer på de fem medverkande skolorna. Under en temadag skulle skolorna arbeta med ämne med inriktning och frågeställningar mot problemområdet kring robotar i ett framtida samhälle och kring teknik för att skapa syntetiskt liv. Lärarna organiserade därför en reflexiv undervisning för temadagen där eleverna först engagerades och introducerades i ämnet och problemställningarna. Sedan gavs möjligheter för eleverna att fördjupa sig i frågeställningarna och bilda sig en uppfattning för att avslutningsvis delta i diskussioner med syfte att de skulle komma fram till en gemensam hållning i frågan inför den kommande internationella förhandlingen i samband med det stundande elevutbytet. Denna undervisning genomfördes i huvudsak på det egna språket, men med lärare som assisterade med simultantolkning till engelska kunde jag följa lektionerna.

Jag besökte varje skola två-tre dagar och förutom att delta i temadagen med reflexiv undervisning gjorde jag även deltagande observationer under ordinarie lektioner. I samband med dessa gavs det tillfällen för mer riktade frågor av epistemologisk karaktär till lärare av olika ämneskategorier. Jag tog hjälp av en frågeguide och i denna fanns även frågor som fungerade som underlag i samtal med elever och skolledningar. Från dessa samtal finns ingen data med i studien, men samtalen bidrog till att få djupare kunskaper om skolkontexten. 
Samtal med lärare skedde både i samband med den reflexiva undervisningen och under ordinarie undervisning och jag förde fältanteckningar under samtalen och nedtecknade de didaktiska dilemman de upplevt som referat.

Efter avslutade temadagar genomfördes även en fokusgruppsintervju med den grupp lärare som arbetat med den reflexiva undervisningen på skolan inom ramen för Erasmus+ partnerskapet. Lärarna hade fått i uppgift att hjälp av fiskbensdiagram (Ishikawa, 1990) sammanställa olika spänningar och motsättningar de upplevt i samband med temadagens planering och utförande men även kring att kontinuerligt arbeta på motsvarande vis (se figur 8). Fiskbensdiagram används för att åskådliggöra orsaker till ett problem där olika huvudorsaker till ett problem kan delas upp mindre delar. Vid de semistrukturerade fokusgruppsintervjuerna i samband med temadagarna användes även en frågeguide som följde fiskbensdiagrammets utformning.

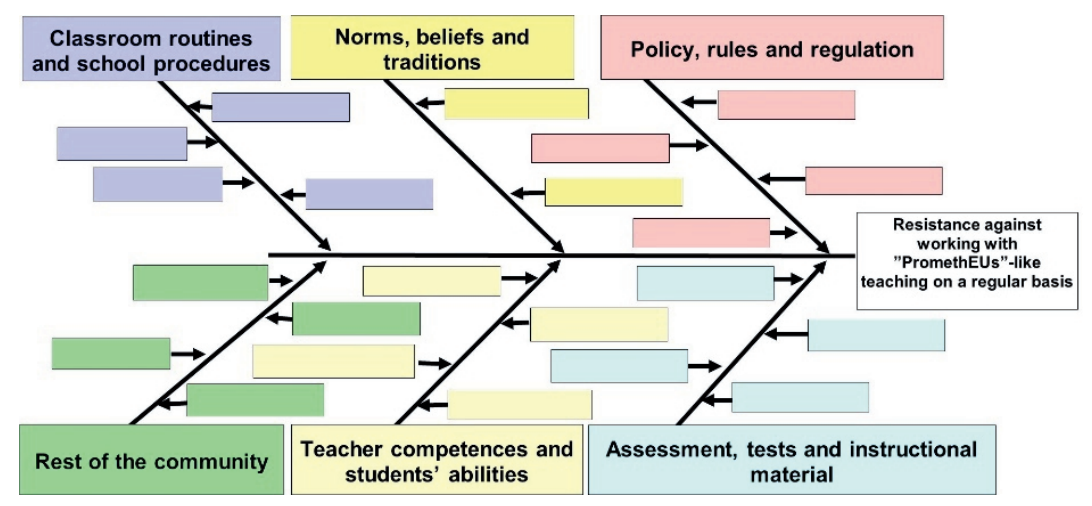

Figur 8. Mall för fiskbensdiagram.

I samband med det tredje och avslutande elevutbytet inom Erasmus+ partnerskapet i maj 2016 genomfördes fokusgruppsintervjuer på motsvarande sätt som vid tidigare elevutbyten. En fokusgruppsintervju med koordinatorerna som deltagare genomfördes och en annan 
med ett par av lärare från respektive land. Som underlag för fokusgrupperna fick de medverkande se på de sammanställda fiskbensdiagrammen som jag gjort för respektive skola.

Precis som tidigare var fokusgruppsintervjuerna semistrukturerade där jag utgick från en frågeguide, men beroende på diskussionerna behandlades fler frågor djupare än andra. Frågeguiden denna gång utgick från analysen med fiskbensdiagrammen där jag identifierat avgörande spänningar i respektive skolas dilemmatic space vilka kan leda till didaktiska dilemman. Fokusgruppen handlade om att deltagarna skulle fördjupa sig vidare i dessa och jag hade särskilt valt ut frågeställningar där man kunde kontrastera didaktiska dilemman mellan de deltagande skolorna.

\section{Analysprocess under fas I}

Fokusgruppsintervjuer transkriberades med hjälp av datorprogrammet f4transkript (Edu-Version v5.70.2). I samband med detta startade ett preliminärt analysarbete, varför själva transkriberingen blev en del av det analytiska arbetet med intervjumaterialet. Fokusgruppsintervjuer transkriberades så ordagrant som möjligt och saker som pauser, avbrott och känslouttryck noterades i utskriften. Analysen av transkriberingen av fokusgrupperna från det första elevutbytet blev grund för intervjuguiden vid det andra och analys av fokusgrupper vid andra elevutbytet ledde fram till utformandet av det fiskbensdiagram som användes under fokusgruppsintervjuerna vid de deltagande observationerna på de fem medverkande skolorna.

De fiskbensdiagram som de olika lärargrupperna själv hade sammanställt inför fokusgruppsintervjuerna användes sedan tillsammans med övriga data från den första fasen i studien i analysen. Eftersom fiskbensanalys är en teknik för att visualisera olika problems orsaker och verkan valde jag att använda fiskbensdiagram för att illustrera resultaten av min preliminära analys. Redan i samband med de deltagande observationerna ute på skolorna analyserade jag mina referat och började sammanställa ett gemensamt fiskbensdiagram för respektive skola. I samband med transkriberingen av fokusgruppsintervjuerna efter temadagarna fortsatte jag steg för steg 
att fylla i ett fiskbensdiagram för varje skola för att få en bild över de spänningar som beskrivits. De fiskbensdiagram som lärarna konstruerat som underlag till själva fokusgruppsintervjun och transskript från tidigare fokusgrupper användes också $\mathrm{i}$ analysen för att få samstämmighet.

Det tredje och sista elevutbytets fokusgruppsintervjuer transkriberades och tillsammans med tidigare data påbörjades en mer omfattande analys. Intervjuerna gjordes på engelska, förutom intervjuerna med enbart svenska lärare, och i analysarbetet användes transskript på engelska. För att underlätta för läsaren har de engelskspråkiga citaten översatts till svenska. Analyser av transkriberade fokusgruppsintervjuer och fältanteckningar gjordes på dator med det kvalitativa analysprogrammet MAXQDA 12 (Release 12.2.0).

Studiens analysarbete hade ett abduktivt tillvägagångssätt. Genom upprepad läsning av transskript och fältanteckningar där kopplingar gjordes till både min egen förförståelse och till tidigare forskning uppnåddes gradvis mer och mer klarhet i förståelsen av hur jag kunde tolka och förstå deltagarnas upplevelser och didaktiska val. I analysarbetet skedde en växelverkan mellan teori och empiri så att det steg för steg växte fram förståelse kring olika spänningar deltagarna upplevde i den reflexiva undervisningen. Svennevig (2001) menar att ett abduktivt tillvägagångssätt i analysen ger funktionella förklaringar snarare än kausala. Lärarnas handlingar och ageranden redovisas istället för att förutspås och jag menar att detta lämpar sig för samhällsvetenskaplig forskning där mänskliga beteenden och ageranden i sig är meningsbärande men även kontextberoende.

Med utgångspunkt från fiskbensdiagrammen, där deltagarna på respektive skola beskrev de övergripande spänningar de känt av i den reflexiva undervisningen, samt mer konkreta didaktiska dilemmana de ställts inför i undervisningen, kunde olika tematiska spänningar extraheras. Dessa fördes in som koder i analysprogrammet tillsammans med koder för andra spänningar som beskrivits i tidigare forskning om liknande undervisning. Under denna första del av ana- 
lysprocessen lästes sedan återigen transkripten igenom och då framkom fler spänningar, vilka lades in som nya koder i analysprogrammet. När det bedömdes finnas koder som täckte in alla de spänningar och upplevda didaktiska dilemman som berörts gick jag igenom alla transskript och fältanteckningar. Segment för segment kodade jag dem med hjälp av dataprogrammet. Eftersom intervjuerna var semistrukturerade, där lärarnas diskussioner delvis vägledde vilka frågor som ställdes, kunde ett uttalande av en deltagare få flera koder. När alla data var kodade gjordes en sortering med hjälp av dataprogrammet så att alla uttalanden och fältanteckningar som tillhörde respektive kod hamnade i ett och samma dokument i programmet. Därefter läste jag igenom dokumenten för vart och ett av de kodade didaktiska dilemmana för att få en överblick.

Jag var intresserad av didaktiska dilemman lärarna upplever när de arbetar med en reflexiv undervisning. Därför sorterades kodade spänningar som betraktades som instegshinder bort. Sådana var exempelvis beskrivningar av att lärarna saknade uppgifter som dessa i sina ordinarie läromedel och att man inte hade tränats i denna undervisningsform tidigare, varken i grundutbildning eller i samband med fortbildningar. Förvisso är detta väldigt avgörande hinder (se vidare: Aikenhead, 2006), men för denna studie var fokus ett annat och studiens undervisningsmodell ämnade därför att hjälpa lärarna över dessa hinder. Efter att jag gjort denna sortering återstod arton kodade spänningar och det blev dessa som valdes för att analyseras vidare i syfte att ge en beskrivning av de didaktiska dilemman lärarna upplevde, samt vilka positioneringar de intog i dessa.

Innan den fördjupade analysen av de beskrivna spänningarna med sina didaktiska dilemman påbörjades gjordes en tematisk analys av de ursprungligen beskrivna spänningarna. Självklart visar sig det konkreta didaktiska dilemmat ytterst på klassrumsnivån, men beroende på spänningarnas karaktär kan dessa ha förankringar till andra delar i undervisningens verksamhetssystem. Tematisering av spänningar tog sin utgångspunkt i Engeströms verksamhetssystem (Engeström, 1987), utan att för den skull göra en fullständig analys utifrån 
de fyra nivåer av motsättningar som Engeström beskriver. Verksamhetssystemets struktur och noder hjälpte dock till att tematisera genom att identifiera den nod där den dominerade motsättningen i de olika identifierade spänningarna fanns. Indelningen gav fyra teman i vilka spänningarna sedan placerades in. Spänningarna och deras didaktiska dilemman är dock inte enskilt förekommande utan sammanlänkade i verksamhetssystemets komplexitet där ett dilemma har relation till ett annat.

De kodade segmenten från studiens data för spänningarna på respektive teman analyserades på nytt för att identifiera sammanhang mellan de didaktiska dilemmana som de beskrivits i studien. De kopplingar som finns mellan spänningarna i skolornas olika dilemmatic space och de olika didaktiska dilemmana möjliggör att dessa kan beskrivas mer som en sammanhängande berättelse och få en något större kontext. När en form av röd tråd hittats genom temats didaktiska dilemman blev nästa steg i analysprocessen att titta på lärargrupp för lärargrupp och analysera deras positioneringar $i$ temats spänningar och didaktiska dilemman. Analysprocessen under denna del av studiens första fas kan ses som första steget $i$ en privilegieringsanalys (Almqvist, 2008; 2014). Genom att läsa uttalanden från fokusgruppsintervjuer och koppla dem till övrig empiri identifierade jag de didaktiska positioner som lärarna på de olika skolorna bedömde som de mest rimliga och fruktbara i de spänningar och didaktiska dilemman som diskuterats. När lärarna positionerar sig på olika sätt i de didaktiska dilemmana innebär det samtidigt att andra positioner och didaktiska val också ignoreras eller väljs bort, trots att de är tänkbara.

Denna analysprocess upprepades sedan för vart och ett av de fyra temana. Genom denna analys av data från deltagande observationer och fokusgrupperna hade 18 olika spänningar framträtt och av dessa gjordes ett urval av spänningar att gå vidare med utifrån spänningar med inneboende didaktiska dilemman som primärt skulle vara intressanta för en reflexiv undervisning i en svensk skolkontext. En del av de arton beskrivna spänningarna, exempelvis rörande re- 
ligiösa värderingar i samhället eller möjligheter för lärarna att samplanera ämnesövergripande var väldigt avgörande spänningar på några skolor men inte för de svenska lärarna och därför valdes dessa spänningar och deras didaktiska dilemman bort.

De spänningar som valdes ut för fortsatt analys var alltså sådana att de bedömdes som mer avgörande sett ur en svensk kontext, men också där det fanns en position som de svenska lärarna tog för given som kunde belysas genom en komparativ didaktisk analys. Det var spänningar som beskrevs på alla de olika skolorna, men där de svenska positioneringarna i det didaktiska dilemmat som regel var av en liten annan karaktär jämfört med övriga. Detta innebär att förutsättningarna för att göra en komparativ didaktisk analys för att avtäcka förgivettagna positioner var goda. Primärt gällde det spänningar som den enskilde läraren upplevde i samband med själva genomförandet av klassrumsundervisningen. De didaktiska dilemman som uppstod på nivån är emellertid förbundna med spänningar $\mathrm{i}$ skolans övergripande strukturer. Hur läraren positionerar sig i de olika didaktiska dilemmana i klassrumsundervisningen beror på hur lärarens position och relation är till olika delar av skolans styrdokument. Fokus för den fortsatta studien lades därför främst på de spänningar som beskrevs under det fjärde temat, vilka gör att didaktiska dilemman uppstår i själva klassrumsundervisningen. Eftersom det är avgörande hur läraren relaterar sig och sin undervisning mot skolans styrdokument togs även spänningsfält rörande dessas olika delar med i den fortsatta analysen.

I andra delen av studiens resultatdel presenteras de utvalda spänningarna, och de didaktiska dilemmana som de orsakar, och de olika lärargruppernas positioneringar beskrivs. Denna sammanställning kan betraktas som resultatet av en privilegieringsanalys första steg. I det fördjupande andra steget av privilegieringsanalysen kom några av de ursprungliga spänningarna som låg nära varandra att kombineras ihop till en mer övergripande spänning som diskuteras integrerat. 


\section{Resultat och diskussion av studiens första fas}

Resultaten från studiens första fas kommer att presenteras i två delar där den första delen behandlar de spänningsfält i den reflexiva undervisningen som framträdde i empirin från studiens tvärnationella fokusgrupper och från de observationer som gjordes i samband med skolornas temadagar. Dessa resultat exemplifierar ett spektrum av spänningar som visade sig på respektive skola och som gav upphov till olika didaktiska dilemman för de deltagande lärarna.

Spänningar som deltagarna upplever i den reflexiva undervisningen I denna första del beskrivs de olika dilemmatic space som aktualiserades under diskussionerna i fokusgrupperna i samband med Erasmus+ partnerskapets tre internationella utbyten samt även spänningar som visade sig under de deltagande observationer som genomfördes på skolorna och som aktualiserades vid samtal och fokusgrupper i anslutning till dessa. Dessa spänningar gav sedan upphov till konkreta didaktiska dilemman för lärarna i arbetet med att planera, genomföra och utvärdera undervisningen.

Analytiskt delas spänningarna upp för att kunna analysera och diskuteras. För att förenkla och för att skapa förståelse beskrivs dilemman som om de hade två motstridiga alternativ, även om verkligheten är mer komplex. Som framgår av spänningarnas benämningar nedan i den numrerade listan låter sig inte alla namnges enkelt och entydigt med en mening, utan benämningen ska ses som en orientering av spänningen och inneboende didaktiska dilemmas karaktärer.

De identifierade spänningarna finns inbäddade i ett större sammanhang där de inte enkelt kan separeras från sin kontext och från varandra. En spänning som ställer läraren inför ett didaktiskt dilemma i den praktiska klassrumsundervisningen har kopplingar till andra nivåer av verksamheten. För att förstå de olika spänningarna indelades de arton som identifierats i fyra olika teman som beskrivs nedan. 
Tema 1: Spänningar kopplade till läroplan, nationella prov och bedömning

1. Det som främst styr planeringen av undervisningen - läroplanens utbildningsmål eller bildningsmål.

2. Nationella provs påverkan på undervisningens innehåll - stor eller liten.

3. Betygsbedömning av elevernas insatser under temadagen samla underlag för ämnesbetyg eller inte.

4. Utrymme för lärare att själv välja metod och innehåll i sin undervisning - stort eller begränsat.

5. Utrymme att diskutera kontroversiella ämnen som inte ingår i läroplanens centrala innehåll - stort eller begränsat.

Tema 2: Spänningar kopplade till rådande religiösa värderingar och politiska åsikter i samhället

6. Religiösa värderingar i samhället och deras påverkan på lärarens val av metoder och innehåll - betydande eller ringa.

7. Politiska åsikter i samhället och deras påverkan på lärarens val av metoder och innehåll - betydande eller ringa.

Tema 3: Spänningar kopplade till lärares ämnesövergripande samarbeten

8. Socioekonomiska utmaningar i relation till lärares gemensamma planering av nya undervisningsmetoder - påtagliga eller obetydliga.

9. Gemensam arbetstid på skolan för lärarna att ska samplanera undervisningen - mycket eller lite.

10. Samordning mellan ämneslärare i utvecklandet av elevernas förmågor för kritiskt tänkande - omfattande eller obefintlig.

11. Möjligheter att bryta ordinarie schema för att arbeta tematiskt och ämnesövergripande - stora eller begränsade.

Tema 4: Spänningar kopplade till själva genomförandet av klassrumsundervisningen

12. Tid läraren väljer att lägga på självstudier av ämnesinnehållet utanför eget ämne - mycket eller lite. 
13. Arbetsform i den reflexiva undervisningen- helklass eller grupparbete.

14. Metod för elevers inhämtade av information - lärarförmedling eller elever letar själv.

15. Gruppering av elever vid diskussioner - heterogena eller homogena grupper.

16. Anpassningar till tysta elever - anpassning för dessa eller ingen anpassning.

17. Förhållningssätt till frågeställningen - stark objektivitet eller svag objektivitet.

18. Egna åsikter rörande frågeställningen - stark neutralitet eller svag neutralitet.

\section{Tema 1: Spänningar kopplade till läroplan, bedömning och nationella} prov

De fem första spänningarna bildar ett tema genom att dessa har sin tyngdpunkt på undervisningssystemets makronivå och berör hur lärarna positionerar sig gentemot skolans styrsystem. Spänningarna är kopplade till hur läraren ska omvandla olika nationella styrdokument till konkret undervisning i klassrummet. Tolkningar av läroplaner och betydelse av nationella prov kan regleras på skolnivå genom att man från skolledningen lägger emfas på olika delar. Dessutom påverkas läroplaner och andra nationella styrsystem av internationellt formulerade utbildningspolicys och internationella mätningar av elevers kunskapsresultat eller globala skeenden som klimatförändringar. Lärarens egna erfarenheter, undervisningstraditioner på skolan och läroplansnormer kan också påverka lärarens handlingar. Skolans styrsystem kring vilka kunskaper som bedöms viktiga påverkar utrymmet för en reflexiv undervisning, men en förutsättning för denna undervisningsform är också att läraren känner att den har utrymme gentemot samhällets diskurs.

Tema 2: Spänningar kopplade till rådande religiösa värderingar och politiska åsikter $i$ samhället

Det andra temat som urskildes av de olika spänningar i undervisningen som lärarna tog upp berör det ovannämnda och är spänning- 
arna nummer sex och sju i listan ovan, Dessa spänningar har en förankring på en samhällsnivå där gällande politiska strömningarna och religiösa värderingar påverkar lagar, normer och traditioner, vilka i sin tur påverkar skolan och lärare. I skolans närsamhälle med föräldrar, lokala politiker eller religiösa representanter samt även lärarkollegor, sker sedan mycket av mötet mellan läraren och politiska åsikter och religiösa värderingar. Det blir ett växelspel mellan dels hur samhällsnivån direkt påverkar den enskilde läraren kring detta, dels hur närsamhället påverkas för att i sin tur influera den enskilde läraren rörande positioneringar i denna del av en reflexiv undervisning.

Tema 3: Spänningar kopplade till lärares ämnesövergripande samarbeten

Spänningarna i punktlistan från nummer åtta till elva bildar ett tredje tema kring att den reflexiva undervisningen inom studien var ämnesövergripande. Att genomföra en förändrad undervisning innebär att läraren behöver lägga ner mer planeringstid än vanligt. När undervisningen dessutom bedrivs tillsammans med kollegor i andra ämnen, krävs även ytterligare tid för samplanering. Oavsett om eleverna arbetar i en ämnesuppdelad undervisning eller i en ämnesövergripande, finns liknande förmågor i olika ämneskursplaner och man skulle därför kunna samplanera träning av dessa förmågor mellan olika ämnen. Detta kräver emellertid en gemensam planering.

Att arbeta med komplexa frågeställningar inom den reflexiva undervisningen kan gynnas av sammanhållen tid och att flera ämneslärare kan vara tillgängliga för eleverna samtidigt i klassrummet. En möjlighet är att arbeta med detta under tematiska och ämnesövergripande arbetspass som bryter den ordinarie strukturen i skolans schema. När detta görs kan det emellertid skapa spänningar, exempelvis genom att någon ämneslärare upplever att eleverna går miste om tid i förhållande till kursplanen i lärarens ämnen. Det kan även uppstå spänningar rörande fördelningen av undervisningstid mellan olika lärare och olika ämnen i en tematiskt och schemabrytande 
undervisning. Temats spänningar har sin tyngdpunkt på arbetslagsnivå och skolnivå, både lärare emellan och beträffande hur skolledningen fördelar arbetet på skolan.

Tema 4: Spänningar kopplade till själva genomförandet av klassrumsundervisningen

De avslutande sju spänningarna bildar ett fjärde tema där spänningarna primärt är förankrade i klassrumsnivån. Vad gäller lärarnas positioneringar kring just dessa spänningar kunde man i flera fall se skillnader mellan de svenska lärarna och lärargrupperna på de övriga skolorna inom studien. Detta innebar att det fanns goda förutsättningar för en analys i linje med komparativ didaktik där förgivettagna inslag i de svenska lärarnas undervisning analyseras och diskuteras.

\section{Väsentliga spänningar ur ett svenskt perspektiv}

Spänningarna på klassrumsnivån var de som framstod som mest väsentliga och avgörande för de deltagande lärarna från Sverige. Till skillnad från lärarna på studiens övriga skolor upplevde de svenska lärarna generellt de övriga spänningarna betydligt svagare än spänningarna inom detta tema. Vad beträffar religiösa värderingar och politiska åsikter i samhället kunde detta påverka de svenska lärarna i mindre omfattning, främst angående huruvida de skulle dela med sig av sina egna åsikter. I jämförelse med studiens turkiska, italienska och polska deltagare var detta dock ett betydligt svagare spänningsfält. Beträffande det tredje temat upplevde även de svenska lärarna utmaningar kring detta, men för dem fanns det praktiska förutsättningar till samarbete. För flera av de övriga deltagarna fanns däremot tydligare spänningar angående en arbetsfördelning med få gemensamma mötesytor och bristande socioekonomiska förutsättningar i samhället som exempelvis brist på barnomsorg.

Med utgångspunkt i forskningsfråga II fokuserade jag på väsentliga aspekter av en reflexiv undervisning sett ur en svensk kontext när jag besvarade forskningsfråga I b. Spänningar i Tema 4 valdes ut för att fördjupas i den fortsatta studien med undantag för spänningen 
beträffande lärarens självstudier då detta snarare kunde betraktas som en konsekvens av positioneringar i övriga spänningar.

13. Arbetsform i den reflexiva undervisningen- helklass eller grupparbete.

14. Metod för elevers inhämtade av information - lärarförmedling eller elever letar själv.

15. Gruppering av elever vid diskussioner - heterogena eller homogena grupper.

16. Anpassningar till tysta elever - anpassning för dessa eller ingen anpassning.

17. Förhållningssätt till frågeställningen - stark objektivitet eller svag objektivitet.

18. Egna åsikter rörande frågeställningen - stark neutralitet eller svag neutralitet.

I resultatavsnittets andra del nedan beskrivs de olika lärargruppernas positioner gällande de didaktiska dilemman som dessa spänningar gav upphov till. Det var i dessa beskrivningar som de svenska lärarnas didaktiska val och positioner speglades i en komparativ analys under nästa fas av studien. Då de svenska lärarnas positioner i denna del av den reflexiva undervisningen har starka relationer till hur de positionerar sig, och positioneras, av skolans styrdokument beskrivs även de tre första spänningarna från Tema 1 i denna andra del.

1. Vad som främst styr planeringen av undervisningen - utbildningsmål eller bildningsmål

2. Nationella provs påverkan på undervisningens innehåll - stor eller liten.

3. Betygsbedömning av elevernas insatser under temadagen samla underlag för ämnesbetyg eller inte

Sammantaget valdes således hälften av de ursprungliga arton spänningarna ut för att fördjupas. Innan dessa fördjupas görs först en kortare sammanfattning av hur studiens övriga lärargrupper upp- 
levde den reflexiva undervisningens utifrån samtliga arton spänningar som identifierades. Detta för att erbjuda läsaren ett större sammanhang för respektive lärargrupps beskrivningar kring de utvalda spänningarna.

\section{Polen}

De polska lärarna beskrev att de kände sig starkt styrda mot en undervisning som främst fokuserar på skolans utbildningsmål med fokus på faktauppgifter. Lärarna förklarade att de har en kursplan med ett omfattande centralt innehåll och nationella examensprov med fokus faktakunskaper. Den enskilde läraren kan vidare ställas till ansvar för dåliga elevresultat och detta skapar lite utrymme för en undervisning som den i studien, eller för den delen för att behandla kunskapsinnehåll som inte explicit är med i ämnenas kursplaner. Pressen att förmedla det omfattande kunskapsinnehåll, vilket lärarna beskrev som alldeles för omfattande, innebär att deras lektioner behöver vara detaljplanerade och detta kunde ses i samband med temadagen där lärarna noggrant hade förberett sig på det innehåll i de kontroversiella frågorna som låg utanför det traditionella stoffet.

Lärarna agerade kunskapsförmedlare i klassrummet och förhöll sig sakligt och opartiskt i diskussionerna men menade att de uttryckte sina egna åsikter i diskussionerna, förutom möjligen om man har en åsikt som är kontroversiell för den rådande politiska ordningen. När de uttryckte egna åsikter menade lärarna dock att de gjorde det utan att direkt försöka påverka eleverna. Att bedöma elevernas insatser i samband med muntliga diskussioner kring kontroversiella ämnen menade de polska lärarna inte var något som finns med i betygskriterierna, så studiens polska lärare upplevde inga dilemman kring bedömning och gjorde inte heller någon bedömning. Att utveckla förmågor kring detta ansåg lärarna främst vara något för starka elever och det faktum att elevers deltagande i muntliga diskussioner inte är något framlyft i styrdokumenten, kan kopplas till att lärarna därför inte ser detta som någon obligatorisk förmåga att utveckla. 


\section{Turkiet}

Både lärarna och eleverna på den turkiska skolan var positiva till den reflexiva undervisningen och lektionerna under temadagen var välplanerade och varierande. Noterbart var att trots att det var stora klasser så var lärarnas klassrumsledarskap effektivt och eleverna ställde snabbt om mellan lektionens olika moment. Lärarna uttryckte att de ville arbeta mer med en undervisning som denna, men de upplevde sig starkt positionerade mot att arbeta mot läroplanens utbildningsmål. Detta inte minst genom att alla klasser följer en och samma lärobok, och innehållet i denna blir det som också prövas i samband med nationella prov. Dessa prov är i sin tur betydelsefulla för elevernas framtida val av skolor och utbildningar. I själva klassrumsundervisningen innebar de stora klasserna och avsaknad av elevdatorer att lärarna begränsades i möjligheterna att låta eleverna själva vara aktiva kunskapsproducenter. Information och olika perspektiv beträffande de kontroversiella frågorna förmedlades därför av läraren. Trots det stora elevantalet i klassrummet lyckades man med att låta eleverna diskutera både i mindre grupper och i helklass.

Lärarna beskrev att det rådande politiska synsätt i landet och samhällets religiösa värderingar skapar didaktiska dilemman vilket inverkar på elevernas möjligheter att fullt ut subjektifieras i den reflexiva undervisningen. Om någon frågeställning har aspekter som strider mot starka uppfattningar i samhället undvek lärarna att diskutera den. Lärarna beskrev även att om något kontroversiellt ämne som inte behandlas i läroplanen kan det dessutom orsaka problem för lärarna om någon förälder skulle reagera och gå vidare med saken. Erasmus+ partnerskapet gav lärarna en möjlighet att utveckla undervisningen tillsammans men detta belyste ett didaktiskt dilemma kring begränsad gemensam planeringstid och avsaknaden av egna arbetsplatser för detta på skolan. På skolan arbetade lärarna i två skift och efter undervisningens slut tog nya elever och kollegor plats på skolan. De turkiska lärarna beskrev att lärarna tvingas att arbeta enskilt med skolutvecklingen då lärarnas planeringsarbete inte gjordes på skolan. För studiens förhållandevis unga turkiska lärare innebar avsaknad av barnomsorg för lärarnas yngre barn att de därför förlade planeringsarbetet i hemmet. De beskrev att de och 
deras respektive synkroniserade sina arbetstider och kombinerade planeringsarbetet hemma med omsorg om barnen, samtidigt som deras respektive gick till sitt arbete.

\section{Kroatien}

För lärarna på den kroatiska skolan beskrevs liknande dilemman. De menade att god undervisning, och utveckling av denna, kräver planeringstid, för den ämnesövergripande undervisningen som bedrevs inom studien även gemensam planeringstid. Precis som på den turkiska skolan har många kroatiska skolor flera undervisningsskift och därmed korta skoldagar för eleverna med korta raster. Detta innebär att det i princip inte finns några tillfällen för planering för läraren under själva skoldagen. Denna tid för planering finns på eftermiddagstid, men då stängs skolbyggnaden och läraren gör därför sin planering hemma. De kroatiska lärarna beskrev att en stor del av lärarna känner sig tvingade att ha ytterligare ett jobb vid sidan om av ekonomiska skäl och detta inverkar i sin tur på den tid som lärarna skulle lagt på planering. Man menade att detta dilemma innebar att lärarna ibland såg lärarjobbet som sina "andrajobb" och tillstod att man la mindre tid på planering och utveckling av undervisningen än vad de skulle kunna göra.

Vad beträffar didaktiska dilemman kring hur läraren ska arbeta mot olika former av mål i läroplaner och hur mycket läraren planerar sin undervisning efter nationella prov beskrev studiens kroatiska lärare att de egentligen upplevde att de har stor frihet att positionera sig. Dessutom finns det inga obligatoriska nationella prov att utvärdera undervisningen efter. Däremot innehåller läroplanen ämneskursplaner med väldigt detaljerat innehåll och de kroatiska lärarna beskrev att traditionen gör att mycket av undervisningen präglas av detta innehåll, trots att läraren egentligen har andra möjligheter. De kroatiska lärarna ansåg också svag implementering av nya läroplaner och att myndigheternas krav att läraren dokumenterar all planering som ett hinder för att göra något annorlunda i undervisningen. I samband med temadagens undervisning blandade man en mer lärarstyrd undervisning med en undervisning där eleverna var mer aktiva 
kunskapsproducenter och man diskuterade både i grupper och i helklass. När lärarna tog upp olika kontroversiella frågor upplevde man ingen påverkan från politiska ståndpunkter eller religiösa värderingar och man belyste initialt frågorna på ett objektivt vis genom att visa på olika aspekter. Vad gäller det didaktiska dilemmat kring lärarens neutralitet såg de kroatiska lärarna det som en självklarhet att de gav uttryck för sin åsikt i frågan och menade att det är en viktig del av eleverna utvecklande av förmågor kring argumentation som grund för kritiskt tänkande.

\section{Italien}

Precis som studiens kroatiska lärare såg även de deltagande italienska lärarna det som naturligt att dela med sig av sina egna åsikter. De var uttryckte även en medvetenhet om att de gärna också försökte påverka eleverna med dessa. Observationer av temadagens undervisning bekräftade lärarnas uttalande om att det var en del av deras tradition att som lärare socialisera eleverna. Eleverna upplevdes dessutom vara mottagliga för intryck från de vuxna i skolan, vilket i sin tur kan skapa en begränsning av möjligheterna för eleverna att ta egen ställning i samhällsdilemmana. Skolans lärare berättade att det fanns starka religiösa värderingar hos en del lärare och även i närsamhället. I de fall de kontroversiella frågorna hade aspekter som var i strid med de religiösa värderingarna uppstod också konflikter mellan de deltagande lärarna. Det gällde frågor kring abort och homosexualitet där någon lärare inte ville diskutera dessa frågor i sitt klassrum utifrån undervisningsmodellens frågeställningar. De övriga deltagande lärarna på skolan upplevde emellertid inte några hinder för att diskutera ämnena i sina klassrum.

De italienska lärarna nämnde vid flera tillfällen att de som lärare upplevde att de hade en stor frihet att både välja undervisningsmetoder och att välja kunskapsinnehåll, även om den senare friheten motsades av skolans rektor. Oavsett vilket beskrev lärarna att det uppfattades som att det fanns alla möjligheter att arbeta mer med kontroversiella frågor inom en reflexiv undervisning ur ett styrdokumentperspektiv. Samtidigt kan denna upplevda frihet också skapa utrymme för en lärare att välja bort att undervisa på detta vis eller 
välja bort frågeställningar och aspekter som inte är i linje med dennes egna värderingar. Studiens italienska lärare påpekade att styrdokumenten och de nationella examensproven öppnar upp för en undervisning som inte är faktakunskapsinriktad, men att traditioner och lärarnas autonomi bromsar förändringstakten.

Den reflexiva undervisningen i samband med temadagen skedde i helklass där eleverna delvis hade förberett sig, men där frågan sedan belystes genom att läraren förmedlade information och fakta om olika aspekter. Diskussionerna genomfördes därefter i helklass med läraren som samtalsledare och åsikterna växlade fram och tillbaka. Likt de kroatiska och turkiska lärarna utförde lärarna sin planering huvudsakligen hemma och det fanns endast begränsad gemensam arbetstid för gemensam planering och för att kollegialt utveckla undervisningen. Denna begränsade gemensamma tid på skolan innebar att trots att man arbetade ämnesövergripande med över tio inblandade lärare skedde merparten av den omfattande gemensamma planeringen inom partnerskapet via e-postkonversation, istället för personliga möten.

Deltagarnas positioner kring didaktiska dilemman de upplever i en reflexiv undervisning

I analysen av data kunde en del överensstämmande teman kring spänningar utskiljas där man kan göra komparationer mellan olika sociokulturella kontexter. Nedan beskrivs hur de olika lärargrupperna positionerade sig i ett urval av de spänningar som finns i den reflexiva undervisningen. Urvalet av spänningar gjordes som nämnts tidigare med utgångspunkt från de som bedömdes som mer relevanta för en svensk kontext och i linje med studiens forskningsfrågor II och III.

I den fördjupning som görs nedan kommer det visa sig att en del av de ursprungligen beskrivna spänningarna ligger nära varandra och har en stark relation till varandra. Därför kommer dessa att beskrivas som en gemensam spänning vilket gör att de nio ursprungliga spänningarna som valts ut beskrivs nedan som fyra övergripande spänningar. 
A. Spänningar kopplade till skolans styrdokuments utbildningsmål och bildningsmål (Spänning 1, 2 och 3)

B. Spänningar kopplade till val av arbetsformer (Spänning 13 och 14)

C. Spänningar kopplade till lärarens ställningstaganden (Spänning 17 och 18)

D. Spänningar kopplade till anpassning av undervisningen (Spänning 15 och 16)

\section{A. Spänningar kopplade till skolans styrdokument utbildningsmål och bildningsmål}

Det fanns en konsensus bland deltagarna att en reflexiv undervisning gav viktiga kunskaper och förmågor för eleverna att ha nytta av i sina fortsatta liv och lärarna i studien uttryckte även att eleverna uppskattade undervisningen. Samtidigt upplevde deltagarna spänningar kopplade till utbildningssystemets styrdokument som begränsade deras möjlighet att arbeta med en undervisning som denna. Detta avsnitt berör de spänningar som lärarna upplever det finns i styrdokumenten angående utbildningsmål och bildningsmål och spänningar kring i vilken utsträckning skolsystemens olika nationella prov påverkade undervisnings innehåll. Relevant för de svenska lärarna var även i vilken omfattning elevernas insatser under studiens temadag skulle bedömas för en framtida betygssättning och underlag skulle samlas in. Denna spänning har en tydlig relation till vilka mål som prioriteras i undervisningen.

Lärare i samtliga lärargrupper förutom den turkiska menade att det fanns stöd för denna typ av undervisning i deras läroplaner eller i läromedlen. Då man arbetar med samma lärobok i alla turkiska skolor blir läroplanen och läroboken intimt sammankopplade och på nationella prov och motsvarande testas det som står i läroboken.

Vi gillar detta sätt med öppna frågeställningar och argumentation och skulle vilja göra det mer. Egentligen är våra elever redo för dessa förmågor, men läroplanen och våra läroböcker är inte det. Läroplanen, när jag pratar med lärare känner de att de måste 
hålla jämna steg med denna och tycker därför att det är förlorad tid att arbeta med öppna frågor. Istället ger de eleverna faktakunskaper och läser om sakerna för att sedan gå vidare till nästa område och i examensproven frågas det bara efter faktakunskaper. Proven vässar inte deras hjärnor, tvärtom eftersom det bara handlar om fakta. (Nihat, Turkiet)

De övriga deltagarna beskrev att deras läroplaner nu var reviderade och att de inkluderade de förmågor som denna form av undervisning syftar till att utveckla och även var inriktade mot demokratimål. Lärarna var medvetna om läroplanens skrivningar och de såg att undervisning på detta vis motsvarades av beskrivna bildningsmål i sina läroplaner. Samtidigt upplevde de att fokusera alltför mycket på dessa bildningsmål kunde skapa en motsättning mot att fokusera på läroplanens utbildningsmål. Sett utifrån den nuvarande svenska läroplanen kan skolans utbildningsmål ses som att de beskrivs i ämnenas centrala innehåll och deras kunskapskrav, medan bildningsmålen är de förmågor som beskrivs både i läroplanens första två delar samt i ämneskursplanernas syftestexter.

De polska lärarna beskrev att deras centrala innehåll är omfattande och att innehållet är på en för avancerad nivå. En lärare exemplifierade med att han ska lära ut formeln för specifik värmekapacitet och menar att han lär dem använda formeln och att bryta ut olika storheter, men bara någon enstaka i klassen förstår vad det handlar om. Trots att han vid upprepade tillfällen påpekar att det inte är rätt att undervisa på denna avancerade nivå och med så komprimerat innehåll upplever han att han inte har möjlighet att förändra sin undervisning utan upplever sig helt styrd av kursplanernas innehåll och de nationella examensproven.

I alla deltagande länder utom i Kroatien har man någon form av nationellt utformade prov som eleverna gör. Dessa kan ha olika syften som att urskilja elever inför nästa skolform, att utvärdera undervisningen och att styra undervisningen och de kan även kopplas till internationella kunskapsmätningar på en supermakronivå. De polska lärarna beskrev att man tidigare hade examensprov med 
större inslag av diskussion och analys men att nuvarande examensprov handlar mycket om faktakunskaper. I NO-ämnena ligger fokus på att definiera begrepp och behärska formler snarare än att resonera och diskutera kring detta och kreativt lösa problem.

För att klara dessa tester behöver man ha faktakunskaper. Testerna kollar inte av att analysera fakta eller att uttrycka sin åsikt om något, bara att känna till saker. "Vad är befolkningen av någonting" ? Detta är problemet och vi förbereder dem [eleverna] bara för att de ska få bättre resultat på testerna. Faktum är att vi ibland glömmer bort att analysera, fundera på, skapa och uppfinna och detta är något jag är medveten om. (Piotr, Polen)

De polska lärarna menade att det är viktigt att deras elever lyckas på dessa examensprov, vilket även eleverna gjorde. För de allra flesta eleverna spelar resultaten på examen ingen större roll eftersom dessa kommer efter betygen är satta. Om en elev ska söka till vissa gymnasieskolor med stor konkurrens om platserna, kan de dock spela roll, men det berör endast ett fåtal elever. Det som gör proven viktiga för lärarna är istället att skolledningen jämför resultaten på examensproven mellan olika lärare och från år till år. Inför varje examen måste också lärarna skriva på en försäkran om att de arbetat med hela det omfattande centrala innehållet i ämnena. På en lokal nivå görs även jämförelser mellan skolorna vilket innebär att även rektorn känner en press på sig att skolan presterar goda resultat på dessa prov för annars blir denne ansvarsskyldig gentemot lokala myndigheter och politiker. I den övergripande spänningen mellan att planera undervisningen mot bildningsmålen eller utbildningsmålen innebär de nationella provens betydelse att de polska lärarna positionerar sig så att de mot sin vilja fokuserar på utbildningsmålen framför bildningsmålen.

De turkiska lärarna beskrev en liknande situation och menade att läroböckerna i NO-ämnena innehåller många detaljerade fakta som eleverna ska lära sig och det blir svårt att hinna med att lära ut helheterna. Den menade att det är möjligt att gå ifrån den föreskrivna 
läroboken, men gör man det för mycket finns risk att någon inspektör reagerar. Dessutom är de nationella proven kopplade till innehållet i läroboken vilket innebär att lärarna upplever att de därmed måste följa bokens planering. Dessa examensprov är avgörande för eleverna eftersom resultaten vägs samman med betygen och används som underlag för antagning till nästa skolform. De turkiska lärarna beskrev hur de känner en förväntan från föräldrar att följa läroboken framför att arbete med egna uppgifter, samtidigt som de känner sig begränsade att genomföra viss form av undervisning på grund av att de har mycket stora klasser i begränsade lektionssalar.

\begin{abstract}
I NO-böckerna är det mycket detaljer och fakta som eleverna ska lära sig och detta gör att de inte förstår något. Jag vill lära dem mer helheter och att diskutera. Jag gör en del andra saker förutom det boken säger. Det finns inte någon lag som säger att man måste följa boken, men det är det som myndigheterna vill... (Hakan, Turkiet)
\end{abstract}

De svenska lärarna kände visserligen inte att deras läroplan och nationella prov är styrande i den grad som beskrivs av de turkiska och polska kollegorna, men de upplever att de senaste åren känt sig allt mer påverkade. De beskrev att de upplever att de har mer ämnesinnehåll de förväntas förmedla till eleverna och att de nationella proven styr undervisningen mer än tidigare. Det senare menade de hänga samman med att kopplingen mellan resultat på nationella proven och elevernas slutbetyg har fått betydligt större betydelse. Denna ökade betydelse visar sig på skolnivå där skolans rektorer påtalar sambandet och gör jämförelser mellan skolor och ämnen, men lärarna menade även att en form av kollegial kontroll av varandra kan uppstå.

Jag tror att man bevakar varandra. "Jaha, diffar du $16 \%$ mellan betygen. Jaha, har du $40 \%$ diff. Vad f-n håller du på med". Den slags kollegial bevakning vi får - då är vi farligt på det. (John, Sverige) 
I Kroatien har man inga nationella prov liknande de som finns i de övriga skolorna. Man har emellertid nationella tävlingar i olika ämnen och lärarna menade att undervisningens innehåll delvis riktas mot dessa. Elevernas resultat från dessa påverkar inte eleverna betygsmässigt och har endast betydelse om man ska välja någon speciell gymnasieskola. Resultaten i tävlingarna kan däremot ha betydelse för lärare då goda resultat ger karriärmässiga fördelar. Lärarna på den kroatiska skolan menade emellertid att deras läroplan i stort öppnar upp för att arbeta mot både bildningsmål och utbildningsmål. Det finns möjligheter i läroplanen att arbeta annorlunda men de hävdade att de kroatiska lärarna förenklar det hela genom att skylla på läroplanen.

Men problemet är inte i skolämnet, problemet ligger hos lärarna. I lärarnas motivation. Jag tycker inte att vår läroplan är så dålig. Jag tycker att den är lik den svenska läroplanen. Som jag ser det är det inte så stor skillnad. (Ante, Kroatien)

Det finns en del socioekonomiska dilemman för de kroatiska lärarna som kan bidra till att undervisningen inte utvecklas. Även om läroplanen i stort är bra upplevde studiens kroatiska lärare också, precis som lärare i Turkiet och Polen, att ämneskursplanerna är väldigt detaljstyrande och omfattande, till exempel med fokus på mycket begrepp och formler inom fysikundervisningen. Lärarna uttryckte även att de upplever ett tryck från skolledning och lokala skolmyndigheter, samt från föräldrar, att undervisa specifikt mot det innehåll som kursplanerna föreskriver. Lärarna måste dokumentera terminsupplägg och lektionsplaneringar och om de ska göra något utöver det vanliga måste detta dokumenteras extra och tillstånd från föräldrar behövs om man exempelvis ska lämna skolbyggnaden. Lärarna menade att detta sammantaget ger dem begränsat utrymme att arbeta annorlunda och istället blir mycket av undervisningen traditionell med inriktning mot utbildningsmålen i kursplanerna.

Den italienska lärargruppen menade på samma vis som de kroatiska lärarna att de inte upplever deras läroplaner som ett hindrar för dem 
att arbeta annorlunda och inte heller de nationella proven där problemlösning och att använda sig av information och faktakunskaper testas. Man menade dock att traditionens makt är stor vilket gör att en hel del undervisning ännu är inriktad mot utbildningsmål i form av faktakunskaper. Lärarna förklarade att italienska lärare har rätt enligt lag att själv välja på vilket undervisningssätt de vill och denna lärarautonomi kan också medföra att lärare behåller traditionella undervisningsmetoder, även om ny läroplan och nationella prov pekar i en annan riktning. De italienska lärarna upplevde även att de hade en viss frihet att välja bort en del av kursplanernas ämnesinnehåll, något som emellertid deras rektor menar inte har stöd i skollagen.

I Italien är det för tillfället ett stort glapp mellan vad som utvärderas i de nationella testerna och vad som lärs ut i skolorna. Läroböckerna är traditionella med stycken och innehåll som man ska memorera och så vidare. Många av dem, även om en del försöker förändra sig. Men i de nationella testerna ska eleverna lösa problem och använda sina kunskaper i ett sammanhang...Föräldrarna klagar på detta glapp och säger "Varför ska det testas på detta vis när undervisningen är helt annorlunda?”. Även lärarna klagar på detta. (Sofia, Italien)

Vad gäller de möjligheter som lärarna på de olika skolorna har att välja innehåll och undervisningsmetoder finns en spännvidd mellan de olika sociokulturella kontexterna. Detta gäller även hur de upplever möjligheterna att arbeta med kontroversiella frågor vars innehåll inte tydligt finns i några av skolämnenas kursplaner. Även om de svenska lärarna upplever ett minskat svängrum på grund av det centrala innehållet menar de att fokus på förmågor gör att man ändå har flexibilitet. De italienska lärarna menade också att de har en stor formell och reell autonomi som lärare, medan lärargrupperna i de tre övriga länderna upplever en betydligt mer begränsad reell möjlighet att arbeta utanför de traditionella ramarna. 
I denna del av den reflexiva undervisningen framträder en spänning där lärarna visserligen ser stora fördelar med denna undervisningsform men ser svårigheter att kombinera den med att också arbeta mot läroplanens utbildningsmål. De ser att eleverna kommer att ha nytta av de kunskaper och förmågor de får med sig när de arbetade på detta vis med de kontroversiella frågorna, men samtidigt finns mer eller mindre formella krav att följa en lärobok eller att förmedla ett mer faktainriktat ämnesinnehåll.

De nationella proven i de deltagande länderna ser lite olika ut och kan ha variation i sitt huvudsyfte men i detta sammanhang kan en spänning urskiljas där lärarna både för egen del och för elevernas del upplever det som att de tar en risk om inte resultaten på de nationella proven är tillräckligt bra eller motsvarar betygen. Även om lärarna inser att man inte ska planera undervisning mot proven kan spänningen ändå få denna konsekvens. När det gäller den reflexiva undervisningen i studien var en del av denna ett fokus i diskussioner där undervisningens subjektifieringssyfte lyfts fram och dessutom diskuterades frågeställningar som inte alltid kunde kopplas till ett centralt ämnesinnehåll från läroplanen. De polska, kroatiska och turkiska lärarna i studien var positiva till denna undervisningsform, men menade att de i den ordinarie undervisningen inte vågade ta risken att gå för långt från den traditionella undervisningsformen, då de ser en fara i att detta kan medföra försämrade provresultat.

De svenska och italienska lärarna menade emellertid att moment i den reflexiva undervisningen är relevanta för deras nationella prov. I Italien kan i stället en spänning urskiljas genom den frihet lärarna anser sig ha i att välja undervisningsmetod. De italienska lärarna ansåg att denna frihet visserligen skapar möjlighet för en del lärare att testa innovativa undervisningsmetoder, men samtidigt innebär det att en lärare som bedriver en elevinaktiv katederundervisning också har rätt att göra detta. De italienska lärarna menade att de nationella proven har fokus på att eleverna ska använda kunskaper och på problemlösning men att de nationella provens möjlighet att även utveckla undervisningen undermineras av den upplevda friheten hos 
lärarna att hålla kvar vid traditionella undervisningsmetoder. Lärarna menade att de nationella proven därför inte testar det som alla de elever med traditionella lärare fått lära sig i skolan och det som skolans prov testar. Lärarna hävdade att detta innebär att även föräldrar blir negativt inställda till de nationella proven och den problemlösande undervisning som dessa förordar.

Även om de svenska lärarna inte upplevde att de har ett så styrt system som de andra lärarna i partnerskapet angav, indikerade de att deras autonomi i undervisningen minskat från förgående läroplan till den gällande. Mer fokus har hamnat på ämnenas centrala innehåll och kunskapskrav.

I: Om ni, med handen på hjärtat, när ni planerar er undervisning - del 1 och 2, värdegrund och så, jämfört med del 3, kursplanerna. Vilket läser ni mest?

Mikael: Del 3.

I: Tar du in något från del 1 och del 2 i din planering?

Annika: Alltså det ligger hela tiden så, men jag håller väl med Mikael.

John: Ärligt talat så det jag tycker så det man planerar för är del 3, alltså kunskapskraven för varje arbetsområde och det centrala innehållet. Men, man märker ju att verksamheten bygger ju inte på del 3 utan den bygger oftare och oftare på värdegrundsfrågor.

De svenska lärarnas beskrivning av sin undervisning särskiljer sig från de övriga genom att de menade att undervisningen ger eleverna för lite faktakunskaper. Relaterar man detta till spänningen mellan läroplanens bildningsmål och utbildningsmål kan man se att de svenska lärarna ansåg att den svenska skolan positionerat sig alltför 
långt från ytterligheten att bara lägga fokus på faktainnehållet i utbildningsmål till ytterligheten att arbeta med förmågor utan specifikt kunskapsinnehåll.

I vårt skolsystem har vi olyckligtvis övergett steget där läraren lär eleverna faktakunskaper. I vårt skolsystem står det i lagen att vi ska lära dem förmågor. Det låter väldigt bra, men har du inga fakta utvecklar du inte förmågorna. (Simon, Sverige)

Till skillnad från alla andra lärargrupper kom frågan om bedömning av eleverna, och svårigheterna med detta, inom denna form av undervisning upp frekvent i diskussioner med svenska deltagare. I undervisningsmodellen fanns visserligen stöd för att göra en formativ bedömning, men frågor kring betygsbedömning lämnades över till varje enskild lärargrupp då denna behövdes göras efter respektive skolsystems bedömningsmodeller. De övriga lärarna i de fyra andra länderna uttryckte inte direkt något behov av att bedöma eleverna $\mathrm{i}$ detta arbete och exempelvis fanns det inget i de polska bedömningskriterierna som lärarna menade att de direkt kunde applicera på elevernas diskussioner kring de olika kontroversiella frågorna.

\section{B. Spänningar kopplade till val av arbetsformer}

I detta avsnitt beskrivs lärargruppernas positioneringar beträffande hur de valde att organisera arbetet under temadagen. Det berör två relaterande spänningar som aktualiserades under fokusgruppsdiskussionerna kring temadagen. Den ena spänningen är den mellan att arbeta och diskutera samhällsdilemmana huvudsakligen i helklass eller att låta eleverna arbeta mer i mindre grupper. En spänning som har en nära koppling till denna handlar om huruvida läraren mer aktivt ska vara den som förmedlar relevant information och relevanta kunskaper kring samhällsdilemmat eller om eleverna i större utsträckning ska vara aktiva informationssökare.

I arbetet med temadagen präglades den svenska organisationen av att eleverna arbetade i grupper om ungefär fyra elever som arbetade med några olika frågeställningar samtidigt. Eleverna hade fått en in- 
troduktion kring frågeställningarna som var aktuella innan temadagens arbete, sedan hade de varsin dator till hands och med hjälp av denna letade man på egen hand efter mer specifik information. När gruppen arbetat igenom en frågeställning diskuterade man och argumenterade inom gruppen utifrån sina egna uppfattningar, för att sedan komma fram till en gemensam ståndpunkt för gruppen. Arbetet gjordes i huvudsak av eleverna utan lärarledning, men under arbetets gång gick lärarna runt från grupp till grupp och erbjöd hjälp och gjorde instick i elevernas diskussioner. I slutet av temadagen fick en representant från gruppen delta i en argumentation under ledning av en av lärarna, där en gemensam hållning för skolan skulle bestämmas.

Relaterar man detta till uppläggen på de andra skolornas temadagar hade lärarna där en betydligt mer styrande roll i arbetet. Medan de svenska eleverna endast fick en lärarförmedlad introduktion belystes frågeställningarnas olika aspekter på de andra skolorna betydligt mer fylligt av läraren. Dessa följde och förmedlade i relativt stor utsträckning den sammanställning av aspekter på frågeställningarna som jag sammanställt. Min avsikt med denna var emellertid att det skulle ge bakgrundsinformation till läraren. Studiens undervisningsmodell var gjord med en tanke på en undervisning lik den som de svenska lärarna planerade där eleverna själva skulle finna dessa kunskaper och att lärarna skulle ha sammanställningen som en hjälp för sig själva.

Under temadagarna på den italienska, polska och kroatiska skolan arbetade man med en fråga i taget och arbetsformen var en mix av mer individuellt arbete, grupparbete och helklass. Lärarna gav först en form av föreläsning kring viktiga grundkunskaper och olika aspekter rörande frågan, följd av tillfällen när eleverna kunde inhämta egna kunskaper. Sedan diskuterade eleverna först i mindre grupper och avslutningsvis i helklass. Upplägget på den turkiska temadagen var likt det som beskrivits ovan men här skedde kunskapsförmedlingen helt av läraren, vilket kan förklaras med att det rörde sig om yngre elever i en väldigt stor klass, samt att det även saknades tillgång till datorer eller andra läromedel för att eleverna själva 
skulle inhämta kunskaper och information kring frågeställningarna. Vissa skillnader kan dock skönjas, såsom att lärarna i den italienska skolan tenderade att ha mer helklassdiskussioner jämfört med de polska, kroatiska och turkiska - men den stora skillnaden mellan studiens skolor låg $\mathrm{i}$ att under den svenska temadagen skedde en större del av inhämtning av information och diskussioner på elevnivå, antingen individuellt eller i grupp, och läraren intog en mer passiv roll.

De två didaktiska dilemmana berör ett dilemmafält som kopplas till hur man ser på hur lärande går till och vilka kunskaper som är viktigast att utveckla. De svenska lärarnas val erbjöd eleverna möjligheter att utveckla sina förmågor att själv hitta och granska information, och arbetet i mindre grupper gav alla elever en chans att vara delaktiga i diskussioner och beslutsfattandet och större utrymme att utveckla sina argumentationsförmågor. Samtidig fick de svenska eleverna mindre stöd i att fördjupa kunskaperna och fördjupa sina argument eftersom eleverna på den begränsade tid de hade inte klarade av att få syn på alla de aspekter som den komplexa frågan innehöll. Eleverna på de andra skolorna hade mer stöd av lärarna att förstå komplexiteten i frågeställningarna, men och andra sidan fick de mindre möjligheter att hitta och granska information på egen hand, och om diskussionerna i större utsträckning skedde i lärarledda helklassdiskussioner blev utrymmet för den enskilde eleven att träna sina egna argumentationsförmågor mindre.

\section{Spänningar kopplade till lärarens ställningstagande}

Dessa spänningar kopplas till begreppen objektivitet och neutralitet. Dessa begrepp kan ha lite skiftande innebörd i olika sammanhang. Att vara objektiv kan beskrivas som att ha ett sakligt och opartiskt förhållningssätt, men kan också förstås inom vetenskap som att man håller sig till fakta. I det här fallet används emellertid objektiv i linje med den förra innebörden. Läraren kan beskrivas som starkt objektiv om den diskuterar frågan utifrån olika synvinklar och belyser alla argument som finns kring en fråga. En lärare som är svagare objektiv lyfter däremot fram vissa argument mer än andra, och gör detta av olika didaktiska skäl. 
Att vara neutral kan i vissa sammanhang användas synonymt med att vara objektiv, och det handlar om att inte ta ställning i en specifik fråga. Vad beträffar neutralitet i denna uppsats gäller det i vilken utsträckning lärare uttrycker sina egna åsikter i de kontroversiella frågorna. Har läraren en stark neutralitet uttrycker läraren inte några egna åsikter. Är läraren svagare neutral kan den dela med sig av sina egna åsikter i klassrummet, men det behöver inte innebära att läraren för den skull gör detta för att påverka eleverna att inta samma ståndpunkt. Att vara objektiv respektive neutral är alltså något som delvis överlappar vartannat och bådas motsats kan beskrivas som att vara partisk. Begreppens starka relation gör att de här beskrivs som en gemensam spänning.

I samband med att eleverna skulle diskutera och argumentera kring de komplexa och kontroversiella frågorna ställdes lärarna inför didaktiska dilemman kring i vilken grad de ska eller kan vara objektiva respektive neutrala. Under temadagen kunde man urskilja en del skillnader vilka också diskuterades i fokusgrupper, både på skolan i samband med den deltagande observationen och i samband med internationella fokusgruppsdiskussioner vid partnerskapets elevutbyten.

Vad beträffar den del av objektiviteten som handlar om att ta upp alla olika aspekter och argument kring frågorna som diskuterades fanns det en generell stark objektivitet kring detta. De italienska lärarna diskuterade dock en problematik för en del lärare att hålla sig objektiva om frågan berörde traditionellt religiösa värderingar. De italienska lärarna menade att man ska hålla sig objektiv i frågorna och låta eleverna själva få bilda sina uppfattningar, men menade samtidigt att de själva ibland har svårt med att inte dela med sig av sina egna åsikter och därmed påverka eleverna, om dessa har en avvikande åsikt i en fråga.

I de skandinaviska länderna är man mer liberal och låter folk själv ha åsikter medan man här i Italien behöver vara mer styrande kring åsikter. Det ligger inte i vår kultur att skapa egna åsikter och vi tränar inte heller eleverna i detta. (Daniela, Italien) 
I samband med diskussionerna på temadagen på den italienska skolan, vilka till stor del var lärarledda, var det tydligt att lärarna själv medverkade med sina åsikter i stor utsträckning. De var väldigt nyfikna även på mina åsikter i frågorna och när jag vid ett tillfälle gav uttryck för en åsikt i ett samtal med en lärare vidarebefordrades detta direkt till eleverna. Dessa verkade i sin tur ta intryck av min åsikt. Även om de italienska lärarna initialt var objektiva och belyste frågeställningen ur olika perspektiv innebar deras roll som diskussionsledare som tar personlig ställning, att objektiviteten försvagas och utrymmet för elevernas subjektifiering riskerar att minska. Skolans rektor deltog vid diskussionen om huruvida personer med robotproteser ska få tävla i framtida OS och VM-tävlingar och lyckades genom att argumentera efter sin övertygelse vända opinionen i klassrummet. Även i andra diskussioner var de italienska eleverna mottagliga och påverkbara av de argument som lärarna hade. Lärarna som var medvetna om att de själva tog ställning ansåg emellertid att det är svårt att förhålla sig neutral som lärare eftersom eleverna ändå genomskådar detta.

Bianca: Som lärare ska du inte berätta [din åsikt] för eleverna, men de märker den ändå.

Daniela: Jag försöker att inte uttrycka mina egna åsikter men inser att jag undermedvetet gör det ändå. Troligen för att jag inte är van att arbeta på detta sätt med eleverna.

På liknande vis föll det sig naturligt för de kroatiska att dela med sig av sina egna åsikter i diskussionerna. Under temadagen delade lärarna tydligt med sig av sina egna åsikter. I samband med diskussionen om robotproteser hade eleverna kommit till ett gemensamt ställningstagande att inte tillåta detta, men då läraren som ledde diskussionen hade en annan åsikt fortsatte läraren diskussionen för att övertyga eleverna om att ändra åsikt. Detta lyckades också. Att diskutera med eleverna genom att använda sina autentiska åsikter ser de kroatiska lärarna som en viktig del i undervisningen. 
Ibland säger jag emot mina elever. De har en uppfattning och jag har min men vi försöker då tänka kritiskt baserat på fakta. Åsikter måste underbyggas med fakta. Vi delar med oss av våra åsikter och ibland kanske jag har fel och de har rätt så klart. Att visa detta för mig är grunden för lärande. (Nicola, Kroatien)

Även de turkiska lärarna såg det som en självklarhet att läraren tar ställning i frågor, åtminstone så länge frågeställningar inte är religiöst och politiskt kontroversiella. Till saken hör att de turkiska eleverna i studien är något yngre varför lärarna menade att de därför måste tänka extra på att hålla sig neutrala i dessa frågor då eleverna är mer lättpåverkade. Att läraren är mer neutral i vissa frågor sammanfaller även med att den inte vill riskera att hamna i konflikt med elevernas föräldrar, vilket kan leda till konsekvenser.

Våra elever är lite yngre. Om du uttrycker dina tankar och idéer är det lätt hänt att de tar efter dessa "Detta är min åsikt också". När de sedan kommer hem och pratar om detta med sin familj kan de säga "Du försöker påverka mitt barns idéer, hur kan du göra detta?" (Hakan, Turkiet)

De polska lärarna förhöll sig genomgående starkt objektiva genom att de både beskrev den kontroversiella frågan från olika aspekter och genom att de inte aktivt deltog i diskussionen genom att argumentera för eller emot. Även om de inte alltid gav uttryck för sina egna ståndpunkter $\mathrm{i}$ frågorna sågs det inte som något problem att göra detta. Som beskrivits ovan fanns det emellertid en tveksamhet att uttrycka sig i aktuella politiska frågor. De svenska lärarna särskiljer sig dock eftersom de höll sig strikt neutrala i diskussionerna och inte delade med sig av sina egna synpunkter och åsikter. I huvudsak menade studiens svenska lärare att den starka neutraliteten och att objektivt presentera olika ståndpunkter var för att inte påverka eleverna när de skulle ta en egen ställning.

Etiska dilemman tycker jag ger spännande diskussioner, men jag måste agera moderator och inte ha några personliga värderingar. (Sven, Sverige) 
I och för sig tror jag att det är lätt för läraren att styra elever, eller det vet jag att det är. Förr sa man alltid att "Nu ska jag ha den här åk $7 \mathrm{i}$ samhällskunskap och frågan är om jag ska gör de till kommunister eller moderater". Det kan en duktig lärare styra om man inte förhåller sig objektiv. (Simon, Sverige)

Samtidigt som de svenska lärarna var objektiva när de redovisade olika synsätt man kan ha på den komplexa och kontroversiella frågan och att de höll sig neutrala under diskussionerna, innebar detta inte att de var passiva i diskussionerna. Var det så att läraren ville hålla igång diskussionen längre av olika anledningar intog läraren motsatt åsikt gentemot eleverna och tog upp motargument vilka då nödvändigtvis inte behövde vara lärarens egen åsikt.

\section{Spänningar kopplade till anpassning av undervisningen}

För de spänningar som fördjupats ovan fanns en tydlig variation mellan hur lärargrupperna i de övriga länderna positionerade sig jämfört med de svenska deltagarna. För de två beskrivna spänningarna kring anpassningar för elever som inte aktivt deltog i den reflexiva undervisningens muntliga diskussioner var det något annorlunda. Det fanns en variation mellan hur lärarna positionerade sig, men det fanns en större variation inom respektive lärargrupp. De två spänningarna kring om man ska göra anpassningar i den reflexiva undervisningen har samband med varandra varför de nedan fördjupas under en och samma rubrik.

Temadagen på den polska och kroatiska skolan genomfördes med en klass bestående av elever från olika klasser vilka själv valt att delta i Erasmus+ partnerskapet, medan temadagarna på de övriga tre genomfördes med vanliga klasser. Delar av arbetat med de kontroversiella frågorna på dessa tre skolor genomfördes delvis också med andra elevgrupperingar än den ordinarie klassammansättningen. I fokusgruppsdiskussionerna jämfördes att arbeta med den reflexiva undervisningen i en vanlig klass med elever med olika förmågor, motivation och intressen med att arbeta med undervisning $\mathrm{i}$ elevgrupp som antingen på något vis valts ut eller där eleverna själv 
anmält sig och tagit på sig extra undervisning efter ordinarie lektionstid. Utifrån lärarnas åsikter och positioneringar kan två delvis överlappande spänningar urskiljas.

Den ena spänningen rör att det i en klass finns nivåskillnader bland eleverna beträffande avgörande förmågor som eleverna använder sig av i den reflexiva undervisningens diskussioner. Det gäller förmågor som att sätta sig in i frågeställningen och samla in information för att kunna skaffa sig en väl underbyggd åsikt i frågan. Det handlar om att kunna lägga upp en bra argumentation kring detta och bemöta andra argument i en diskussion. Givetvis finns det en variation i dessa förmågor bland eleverna och det didaktiska dilemmat som lärarna beskrev handlade om man ska anpassa undervisningen så eleverna får argumentera och diskutera med elever på samma nivå eller om dessa moment helt enkelt ska tas bort för elever som är svagare. Den andra spänningen som relaterar till den förra var i vilken utsträckning man ska tvinga tysta eller blyga elever att vara med i de muntliga diskussionerna. Det gäller i detta fall elever som egentligen inte har bristande argumentationsförmågor, men som är tysta eller blyga och därför sällan uttrycker sig annars i diskussioner i klassrummet. Det bör poängteras att vad gäller tysta eller blyga elever i detta sammanhang gäller det inte elever som har talsvårigheter och andra diagnostiserade funktionshinder som kan skapa problem för dem att uttrycka sig i en diskussion.

I lärarnas diskussioner kan man inte direkt urskilja några tydliga och fasta positioneringar när det gäller dilemmat om man ska nivågruppera eleverna utan lärarna ser det från båda hållen. De kroatiska och polska lärarna, vilka arbetade med ett urval av elever under temadagen, argumenterar för att en reflexiv undervisning med diskussioner skulle fungera sämre i en vanlig klass där det även finns svaga och lågpresterande elever.

I: Låt oss saga att vi tar er åtta och gör detta [reflexiv undervisning] med dem [...] göra det med en vanlig klass, vilken skillnad tror ni det skulle vara? 
Janica: De flesta av dem skulle bli uttråkade tror jag.

I: Varför?

Janica: De förstår inte.

I: Varför?

Iva: Ämnet är för komplext.

I: Är du säker?

Nicola: En del elever vill inte lära. De vill bara sova på lektionerna och vill bara gå hem och spela datorspel. Varför? Jag vet inte. Kanske det är deras familjesituation, kanske hur det är i det kroatiska samhället. Vem vet?

I: Men jag förmodar att när de började i ettan så var de glada för att gå i skolan och ville lära sig saker.

Iva: Inte alltid.

Nicola: Vi hoppas men...

Iva: Det är en börda för en del av dem och har så varit $i$ åtta år.

Janica: Det är inte stor skillnad mellan ettan och åttan.

Ante: Jag har dock inte dessa problem med idrottslektionerna. Alla gillar att ha idrott.

Detta synsätt kan kopplas till att lärarna på dessa två skolor beskrev att de upplever sig starkt styrda att hinna med kursplanernas omfattande och detaljerade kunskapsinnehåll där stort fokus är på faktakunskaper. Detta skulle kunna kopplas samman med att elever som beskrivs som uttråkade och arbetsovilliga under teoretiska lektioner inte är detta i ett praktiskt ämne som idrott. Lärarna menade att de 
är positiva till undervisning med diskussioner och öppna frågor, men ansåg sig inte hinna med så mycket av detta. De menade dock att alla elever har nytta av denna form av undervisning, men att det kanske behövs anpassning av undervisningen om den ska genomföras med vanliga klasser.

I varje klass finns det tre eller fyra mer framstående elever. De övriga är inte lika starka och därför ska vi erbjuda en undervisning anpassad för alla elever. Kanske vi någon gång organiserar undervisningen annorlunda, men erbjuder samma för alla. Detta är vad jag tycker, kanske vi ställer lägre krav på en del elever, men erbjuder dem så mycket som möjligt. (Nicola, Kroatien)

I de övriga tre lärargrupperna där man arbetade med vanliga klasser under temadagen uttrycker man inte samma tveksamhet inför att svaga elever skulle arbeta med en undervisning likt den reflektiva undervisningen som bedrevs under Erasmus+ partnerskapet. Det lyftes istället fram argument för att en undervisning där det inte finns "rätta svar" istället kan vara gynnsam för dessa elever.

Jag tycker att metoden att arbeta med öppna frågeställningar är mycket användbar för en del elever, speciellt svaga elever som är blyga och inte vill räcka upp handen. "Jag vill räcka upp handen men tänk om jag har fel?”. Därför räcker de inte upp handen och uttrycker sig själva, men när vi arbetar med sådana här frågor har vi inte ett rätt svar från början. "Vi har inte rätt eller fel utan jag vill bara höra vad ni har för tankar”. När jag säger det försöker de svaga eleverna räcka upp handen mer och deltar mer i klassen under lektionen. Så jag tycker att denna metoden passar bra för svaga elever. (Hakan, Turkiet)

De italienska och turkiska lärarna beskrev även att elever som de betraktade som starka elever utifrån den ordinarie, och mer traditionella, undervisningen inte alltid var de som lyckades bäst i denna nya undervisningsform. Till det första internationella elevutbytet hade de italienska lärarna gjort urvalet av elever beroende på deras betygssnitt, men ändrade vid senare utbyten sin urvalsstrategi. De 
menade att elevernas skolbetyg, vilka de ansåg till stor del byggde på uppvisade faktakunskaper, inte var en bra måttstock på hur bra eleverna lyckades med att bygga upp argument och diskutera kring kontroversiella frågor. Ett svagt samband mellan bra betyg och goda muntliga argumentationsförmågor beskrevs även utifrån en turkisk skolkontext.

För en elev är det enklare att plugga in faktakunskaper än att svara på öppna frågeställningar. Det finns elever, vi kallar dem "kossor" här i Turkiet, som är duktiga på att plugga in saker och får höga betyg. Men om man försöker diskutera med dessa elever så har de inga åsikter, de kan bara fakta. Å andra sidan, om man skulle undervisa dessa elever kring hur man kan besvara öppna frågor, hur man argumenterar, kanske resultaten skulle bli mycket bättre. Om du bara lär ut fakta är det enkelt för dem, de läser om det och memorerar och sedan på examensprovet kan de svara på allt. Om man istället undervisar kring öppna frågor med dem och lär dem argumentation skulle resultaten bli mycket bättre. (Nihat, Turkiet)

Oavsett om eleverna har höga betyg eller inte finns det ändå skillnader beträffande hur bra elever är på att argumentera och diskutera $\mathrm{i}$ den reflexiva undervisningen. I samtalen med lärarna beskrevs att $\mathrm{i}$ de muntliga diskussionerna kan det vara så att elever som är duktiga på att argumentera och diskutera hämmar andra elevers utveckling genom att en duktig elev tar över diskussionen. Genom att nivågruppera eleverna utifrån deras muntliga argumentationsförmåga skulle man kunna undvika detta.

Om man har talföra elever i samma grupp som blyga elever och arbetar med öppna frågor kommer inte de talföra eleverna ge något utrymme åt de blyga eleverna att tala och få uttrycka sina tankar. Därför behöver man separata grupper så att de svaga eleverna ges samma möjligheter. (Bianca, Italien)

Argument för att arbeta med sammanhållna grupper utan nivågruppering lyftes också fram i diskussionerna. Till skillnad från övriga 
lärargrupper var det mer uttalat hos de svenska lärarna att alla elever skulle delta i diskussionerna för att utveckla förmågor kring detta. De förklarade att de testat sätta samman eleverna på olika vis, både efter deras förmågor och även låtit eleverna formera sig själva.

Det är också det att vissa är starkare och då tror jag på att man delar upp dem i grupper som vi gjorde nu och det blev lite att läraren bestämmer. Vi tittade på "starka", "svaga", "styrkor och svagheter" och kombinerade dem i grupper så det inte bara blev homogena grupper. Skulle vi bara sagt "ok, sätt er nu i grupper" skulle det nog blivit mer homogena grupper. Det har vi också testat med framgång så att vissa elever kanske ska klara baskunskaper och då är det bra att ha en homogen grupp. Och de som verkligen vill sträva, sträva framåt - så lyckas man med det på ett annat sätt. (John, Sverige)

Diskussioner och förhandlingar på de lokala skolorna kring de olika frågorna ledde fram till att varje skola utsåg representanter som därefter skulle presentera sin skolas hållning i de olika frågorna för att sedan delta i förhandlingar med representanterna från de andra skolorna. Detta syftade till att komma fram till ett gemensamt beslut för de involverade skolorna kring vad som skulle gälla på den imaginära planeten PromethEUs. Även om delar av den reflexiva undervisningen på skolorna skedde i form av helklassundervisning fanns det under vägen flera moment av grupparbete. I detta arbete fanns olika uppgifter som skulle utföras, såsom att samla in relevant information, lägga upp argumentationen, göra digitala presentationer och presentera dessa samt att delta i de muntliga förhandlingarna. En aspekt på eventuella grupperingar baserat på elevernas styrkor var att se elevernas arbete i den reflexiva undervisningen som en helhet där man inte behövde nivågruppera eleverna, utan istället låta dem inta olika roller i grupparbetet och specialisera sig på olika delar.

Kanske ett bra svar är att i ett sådant här arbetssätt finns en plats för alla. En är bra på att tala, en är bra på att förbereda och en annan är bra på att göra digitala presentationer. (Piotr, Polen) 
Vi valde ut en grupp med elever med olika förutsättningar och de som är lite svagare försöker hitta en enklare roll i projektet. Där är en elev, en sådan elev som alltid hjälper läraren att bära väskan och med datorn. Han sa "Läraren, jag vill tacka dig för denna erfarenheten. Jag kan inte bidra med så mycket men jag försöker hjälpa till så mycket jag kan”. Detta tycker jag är något annat som är ok - att hitta sin roll. (Sofia, Italien)

Lärarnas uttalande ovan bör inte tolkas som att de inte menade att elever generellt i skolan ska utveckla och träna saker de inte är så duktiga på. Samtidigt är det en indikator på att man inte ser det som skolans primära uppgift att samtliga elever ska utveckla alla dessa argumentationsförmågor. Detta leder in på dilemmat hur man didaktiskt hanterar de elever som är väldigt avvaktande till att delta i de muntliga diskussionerna. Även om en lärare inte kan tvinga en elev att vara muntligt aktiv i samband med diskussionerna kring de komplexa och kontroversiella frågorna kan den på olika vis signalera och visa på att läraren anser att muntligt deltagande är obligatoriskt eller frivilligt i undervisningen. Den genomgående positioneringen som lärarna intog var att se muntligt deltagande som frivilligt för de elever som inte var aktiva muntligt. Istället menade man att berörda elever kan erbjudas olika former av anpassningar och redovisa sina ställningstaganden på andra vis.

Jag tycker att alla elever ska delta i dessa aktiviteter, men kanske med lite anpassningar. Låter man dem arbeta muntligt kommer några av dem prata, medan de blyga och tysta eleverna inte gör detta. Om man frågar dem öppna frågor och istället tillåter dem skriva ner sina svar kanske de tysta och blyga eleverna vill skriva. Eller låter man dem måla så att de visserligen inte uttrycker sig muntligt, men ändå uttrycker sig på ett annat sätt. Vi har olika sätt att uttrycka oss på och kan svara på dessa öppna frågeställningar på olika vis. (Nihat, Turkiet)

Att göra anpassningar som beskrivs ovan gör lärarna av empatiska skäl för att dessa elever inte skulle utsättas för obehag, exempelvis 
genom att möjliggöra för eleven att redovisa förmågor och kunskaper för läraren på andra sätt. Detta är givetvis inte klandervärt men detta didaktiska val exponerar dock det didaktiska dilemmats kärnmotsättning, huruvida muntlig förmåga ska betraktas som en medfödd talang eller som en förmåga som är möjlig att träna upp. Vad gäller en hel del andra förmågor och kunskaper som skolorna förväntas lära ut till eleverna agerar inte lärarna på detta vis. Förvisso har vissa elever lättare än andra att lära sig multiplikationstabell eller grammatik, men det är självklart att det går att träna upp färdigheter kring detta och att alla också ska lära sig detta.

Iva: Vi hände en sak i vår grupp. En pojke och en flicka var med i förhandlingen kring Energy. Flickan hade gjort alla förberedelser men pojken skötte allt prat under förhandlingarna. Hon är duktig och snäll men han sa "Hon sa ju ingenting, hon flippade ut". Jag sa "Vänta, hon förberedde ju allting". Det beror mycket på personlighet, en del elever är duktiga muntligt, medan andra inte kan tala för sig.

I: Men ska de inte göra detta då?

Iva: Jag vill ju inte tvinga henne.

I: Tvingar du henne lära sig engelska?

Iva: Jag det gör jag ju, men det är ju för att det står i läroplanen.

Ingen av lärarnas positioneringar var extrem, utan det var en nyanserad diskussion kring att både personlighet och möjlighet att få träna upp sin muntliga förmåga spelar in. I samband med diskussionerna i fokusgrupperna framgick det ändå att flera av lärarna inte i någon större utsträckning hade reflekterat över huruvida man egentligen kan träna upp elevernas muntliga kommunikativa förmåga, utan man såg det mer som en del av deras personlighet.

Izabella: Till exempel har olika elever olika förmågor och olika klasser olika förmågor. Vi har några som jag inte tror skulle klara 
av att vara med i detta projektet. Det skulle vara väldigt, väldigt...Det beror inte bara på de kunskaper de har, för igår behövde de inte ha så mycket kunskaper, utan på förmåga att diskutera och prata inför andra. Det finns flera blyga elever och de gör inte detta. De är för blyga, det är ett annat problem. Det beror även på deras förmågor.

I: Men varför är de blyga?

Jan: Ha, ha.

Piotr: Varför de är blyga? De är konstruerade så!

I: Är det möjligt för en blyg person att bli “oblyg”?

Piotr: Jag tror det i en viss utsträckning. Men som du vet är alla olika. En del är mer talföra och en del mindre och man kan hjälpa någon att utveckla detta till en viss del.

Lärarnas positionering i detta dilemmat kan förstås av att tradition, läroplaner och nationella tester lägger större fokus på andra kunskaper än just elevers muntliga deltagande i diskussioner kring kontroversiella frågor. För de svenska lärarna var utvecklande av elevers muntliga förmågor något som man upplever som viktigt att både utveckla och bedöma i sin undervisning.

Faktiskt är det inte valfritt, alla måste delta när man har en muntlig diskussion i klassrummet och du bedömer dem muntligt. Vi har alla olika personligheter och det är svårt att ändra på dessa. Vissa är tysta och vill inte delta så mycket och vad kan man göra åt detta? Men det finns med i läroplanen och om inte eleven kommunicerar det kan innebära att det kan bli svårare för eleven att få bra betyg om man ska bedöma muntliga kommunikationsförmågor. Du kan bara göra dem medvetna om att detta är förmågor som vi måste betygssätta, men sedan finns alltid olika personligheter. (John, Sverige) 
Även de svenska lärarna positionerar sig mot att en del elever är tysta beroende på att det är en del av deras personlighet. I de svenska lärarnas undervisning beskrev man att eleverna har fått flera möjligheter att diskutera och uttrycka sig muntligt tidigare. Samtidigt tillstod lärarna att de egentligen inte riktigt tränar eleverna i denna förmåga, utan mestadels gett dem möjligheter att använda dessa förmågor. De menade att muntlig förmåga var viktig att utveckla och en förmåga som de åtminstone delvis ska bedöma och betygssätta. Detta var de tydliga med gentemot eleverna, men de tysta eleverna som getts lite träning i detta slapp diskutera muntligt om de inte själv ville. När man har tystare elever som endast deltar begränsat i muntliga diskussioner beskrev de svenska lärarna att de inte på ett "rättssäkert" vis kunde bedöma elevens förmågor och kunskaper efter kunskapskraven. Detta skulle kunna användas för att argumentera för en undervisning med mer tyngdpunkt på skriftliga redovisningar än på de muntliga diskussionerna elever emellan.

\section{Summering av studiens första fas}

Engeström (2008) skriver att ett verksamhetssystems djupa sociala strukturer återfinns i noderna regler, gemenskap och arbetsfördelning. Dessa delar ger undervisningens verksamhetssystem en tröghet vilken skapar spänningar i en förändrad undervisningspraktik som i denna studie. Spänningar som identifierades och grupperades som Tema 1 relaterar främst till motsättningar relaterade till regelnoden i Engeströms verksamhetssystem. Det gäller exempelvis motsättningar i skolans styrdokument och flera i lärargruppen beskrev en spänning genom att påståendekunskaper hade stort bytesvärde för elever och lärare i tester och prov i deras skolsystem. Lärarna menade att de hellre skulle velat förmedla andra former av kunskaper till eleverna, kunskaper som hade större bruksvärde. Dessa spänningar kan ställa läraren inför didaktiska dilemman i planeringen av undervisningen.

Det andra temat utifrån de identifierade spänningarna illustrerar att det finns spänningar där gemenskapen i form av närsamhället kan påverka lärarens handlingar i undervisningen. I lärarens beslutsfat- 
tande kring undervisningsinnehåll i en reflexiv undervisning kan läraren undvika en del aspekter på grund av både religiösa värderingar och politiska strömningar i samhället. Tema 3 illustrerar motsättningar kopplade till främst noden arbetsfördelning. Genom att den reflexiva undervisningen var ämnesövergripande och fordrar mer samplanering blir det spänningar när arbetsrutiner och organisation är inriktade på att lärarna primärt ska planera sin undervisning på egen hand i sina hem. Detta tema illustrerar även spänningar som kan finnas mellan olika verksamhetssystem. Att lärare förlägger arbetet med att planera och utvärdera sin undervisning i hemmet kan också ha relationer till avsaknad av barnomsorg eller ett ekonomiskt behov att ha ett extrajobb vid sidan om arbetet som lärare.

Det fjärde temat, vilket kommer fördjupas ytterligare i nästa kapitel, visar på klassrumsundervisningens komplexitet. Didaktiska val i klassrummet som en lärare måste göra $\mathrm{i}$ den reflexiva undervisningen har kopplingar till alla noder i Engeströms verksamhetssystem. Hur läraren tar ställning i samhällsdilemmana kan kopplas till läroplan, föräldrar och till rådande undervisningsnorm i skolsystemet. Lärarens val av arbetsform har relation till den undervisningstradition som finns, men påverkas även av förutsättningar såsom utrustning och skollokaler samt av hur gällande tolkning av läroplanens olika mål ser ut. Dessutom visar dessa spänningar på att det uppstår motsättningar mellan en förändrad undervisningspraktik och den tidigare praktiken. Spänningar kan blottläggas när nya metoder och undervisningsformer introduceras men genom att man reflekterar över förgivettaganden i sin praktik kan spänningarna hanteras.

Genom analys av data framträdde alltså initialt sammanlagt arton olika spänningar vilka grupperades i fyra teman. Ur dessa gjordes sedan en fördjupning av de nio spänningar som bedömdes vara mer väsentliga för en svensk praktik. Dessa var sex ursprungligt beskrivna spänningar beträffande genomförandet i klassrumsundervisningen och de analyserades djupare. Vidare redovisades de olika lärargruppernas positioner. Spänningarna låg parvis så nära varandra att de analytiskt fördes samman och av dessa blev det tre 
övergripande spänningar. Det var spänningar gällande val av arbetsform, informationsinsamling och diskussioner, lärarens objektivitet och neutralitet samt om läraren ska göra anpassningar för elever vid diskussioner.

Då det visade sig att de svenska lärarnas positioner i dessa spänningar starkt relaterade till spänningar gällande skolans styrdokument fördjupades även tre ursprungliga spänningar kring läroplanens olika mål, de nationella provens påverkan på undervisningen samt spänningar kring bedömning. Dessa bildade i sin tur en fjärde övergripande spänning beträffande hur läraren ska balansera de utbildningsmål som finns för att utvärdera undervisningen och bedöma elevernas kunskaper mot de mer långsiktiga bildningsmålen. 


\section{FAS II - SPEGLINGAR I DIDAKTISKA DILEMMAN}

När de deltagande observationerna genomfördes under fas I var det med början på den svenska skolan, och sedan besöktes den turkiska skolan, följd av den polska och därefter den kroatiska och avslutningsvis den italienska. Redan i samband med initiala analyser av empirin från de utländska skolorna började jag uppmärksamma att en del, i det närmsta förgivettagna, didaktiska val gjorda i den svenska undervisningen i själva verket är olika didaktiska dilemman där valet kan ha en del negativa konsekvenser. Detta blev allt tydligare i jämförelsen med de övriga skolornas didaktiska val. I samband med transkriberingen av fokusgruppsintervjuerna på det avslutande elevutbytet inom partnerskapet påbörjades därför en analys med fokus på några av de avgörande spänningar de svenska lärarna beskrivit och upplevt. Dessa blev i resultatanalysen tydligare i reflektionen mot de övriga skolorna. Även min undervisningsmodell som var sprungen ur en svensk skolkontext kom att analyseras i en form av spegling mot hur övriga skolor organiserat och utfört sin reflexiva undervisning.

Den sammansättning av länder som fanns i samarbetsprojektet gör att den svenska skolan skiljer sig från de övriga. Medan undervisningen här genomgått flera förändringar de senaste årtiondena har de andra ländernas undervisning förändrats långsammare och $\mathrm{i}$ större utsträckning har man där bibehållit mer traditionella undervisningsmetoder. Det finns även kulturella och sociohistoriska skillnader vilka skapat naturliga olikheter i skolsystemen i de olika länderna. I denna studie var det emellertid inte dessa olikheter som skulle jämföras, utan istället skapar den skillnad som finns en intressant spegel för de svenska lärarna, vilka på sätt och vis kan göra en 
tidsresa tillbaka i tiden och därigenom i någon mening studera sin egen praktik retrospektivt, fast i realtid.

Under fas I diskuterades företrädesvis kring spänningar som lärarna upplevde när de hade intentionen att genomföra en reflexiv undervisning. De spänningar av de ursprungliga som fördjupades beskrevs i form av fyra övergripande spänningar. I och med att vi nu går in i studiens andra fas kommer dessa övergripande spänningarna istället diskuteras i termer av didaktiska dilemman. Spänningarna kan ta sig uttryck i didaktiska dilemman i den konkreta undervisningen och detta kapitel handlar om vad som synliggörs när de svenska lärarna reflekterar kring sina egna positioneringar i förhållande till de som deras kollegor i de andra länderna intagit. Detta svarar mot forskningsfråga II. De övergripande spänningarna benämns i detta kapitel istället som metadilemman men de ingående delarna är desamma.

\section{Datainsamlingsprocess under fas II}

Jag valde i detta skede att den fortsatta datainsamlingen skulle fokusera på hur de svenska lärarna ser på de för dem mer relevanta didaktiska dilemman som framkommit, och diskutera detta utifrån min analys och utifrån de erfarenheter som de själv gjort under Erasmus+ partnerskapet. Fokus på de svenska lärarnas upplevelser innebär inte att de övriga lärarnas beskrivningar och upplevelser av spänningarna tappar värde i denna fas av studien. Tvärtom är det just i kontrasten mot dessa som jag tillsammans med lärarna kunde synliggöra de didaktiska dilemman som finns i den svenska skolvardagen när en reflexiv undervisning ska genomföras.

Dessutom, fortsättningen av studien ämnade att diskutera vidare kring olika didaktiska dilemman som uppenbarar sig när de svenska lärarna planerar och genomför en reflexiv undervisning för att skapa en grund till ett diskussionsverktyg. I detta sammanhang gav allas berättelser och alla de positioneringar som lärarna intog ett bidrag till studien. Dessa bidrog dels till att synliggöra de didaktiska dilemman som delvis var dolda i den svenska kontexten, dels till att beskriva alternativa positioner till den som de svenska lärarna primärt intog i den reflexiva undervisningen. Analysprocessen i denna fas 
hämtade inspiration från privilegieringsanalysens andra steg där det handlar om att jämföra lärarens positioner med alternativa positioner som kan intas i det didaktiska dilemmat. Denna jämförelse öppnar upp för en kritisk diskussion om relationen mellan de förgivettagna didaktiska valen och alternativa didaktiska val.

Alla dilemman kan sägas ha minst två ytterligheter som valet står mellan. För båda alternativen finns goda argument för detta val, men samtidigt finns även potentiellt oangenäma följdverkningar. Det finns framförallt också ett kontinuum av alternativa val att göra mellan ytterligheterna. Vad gäller dessa didaktiska dilemman är det vidare inte alltid så att de två ytterlighetsalternativen egentligen står i direkt motsats till varandra, men de står ändå för två olika didaktiska valmöjligheter där det blir problematiskt att välja båda under en och samma undervisningssekvens.

Man skulle kunna illustrera de didaktiska dilemmana vart för sig med dubbelriktade pilar med två ytterligheter i ändarna och ett kontinuum mellan dessa. I valet av ett diskussionsverktyg föll det på att kombinera två närliggande dilemman i koordinatsystem så att det bildas olika fyrfältsdiagram. Vardera axeln i fyrfältsdiagram illustrerar ett didaktiskt dilemma där två ytterligheter sätts i vardera änden och de didaktiska dilemman som valdes att kombineras samman hade under tidigare diskussioner kopplats samman i form av de övergripande spänningarna från fas I. Detta skapar en mycket enkel modell med två dilemmadimensioner i samma diagram och i fyrfältsdiagrammet kan man sedan hitta fyra idealtyper i vartdera hörnet av diagrammet.

Efter att didaktiska dilemman ur de övergripande spänningarna kombinerats i fyrfältsdiagram gjordes en innehållsanalys där jag utgick från analysen från fas I och även gick tillbaka till ursprungliga transskript från fokusgrupper, fältanteckningar samt fiskbensdiagrammen. Jag behandlade en lärargrupp i taget och tittade på data i förhållande till ett identifierat didaktiskt dilemman åt gången. Beroende på analys från fas I positionerade jag varje lärargrupp på det 
kontinuum som varje dilemma illustreras med och symboliserade detta med en flagga, se figur 9.

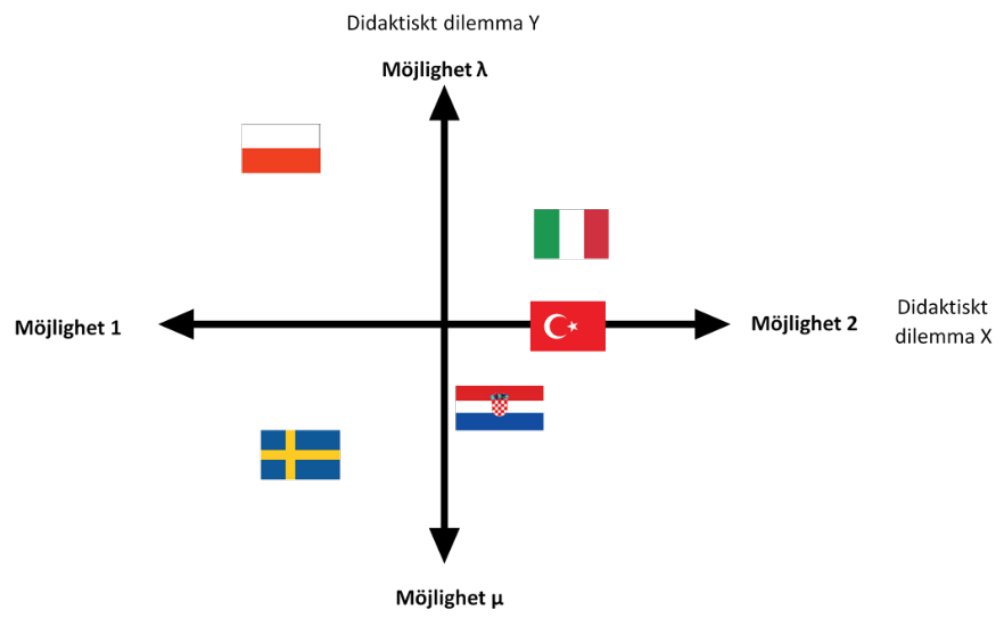

Figur 9. Modell för fyrfältsdiagram som användes i fas II.

Det bör alltså noteras att landsflaggorna symboliserar hur respektive lärargrupp positionerades för respektive dilemma, baserat på analys av deltagande observationer och uttalanden i samband med fokusgrupperna. Alltså ska inte dessa fyrfältsdiagram tolkas som en generaliserad beskrivning av undervisning i olika länder och detta var inte heller avsikten med diagrammet. Tanken var att diagrammen skulle fungera som en spegel för de svenska lärarna och därigenom möjliggöra reflektion kring sina egna positioneringar.

Placering av respektive symbolisk flagga baserades på den analys jag gjort av empiriska data där varje lärargrupps positionering placerades på varje dilemmas respektive kontinuum. Vad gäller placeringen är det uppenbart inte något som är en exakt vetenskap och inte heller något som är generellt gällande för lärargruppen vid alla givna tillfällen. Mina tolkningar i analysen bygger dels på empirin där jag måste förlitar mig på lärarnas egna berättelser i samband med fo- 
kusgrupperna och dels på empiri från de deltagande observationerna, under vilka jag endast får ögonblicksbilder av lärarnas undervisning. När det exempelvis gällde hur lärarna förberedde sig kring ämnesinnehåll som inte ingick i deras vanliga ämnen eller hur de resonerade kring vilka elever denna undervisning lämpade sig för, var det lärarnas egna beskrivningar som gav empiri. När det gällde exempelvis hur undervisningen rent praktiskt organiserades under temadagen kunde empirin kompletteras med egna observationer. Dessutom förhåller man sällan sig entydigt till ett dilemma utan man kan positionera sig olika beroende på situation och lärargrupperna bestod av olika individer som agerade på olika vis.

Vidare var tanken med fyrfältsdiagrammen att de skulle fungera som underlag för diskussioner med de medverkande svenska lärarna och de syftade inte till att vara något slutgiltigt resultat för en komparativ studie av olika länder. Dessa fyrfältsdiagram skulle utgöra en sammanvägd bild av hur de olika lärargrupperna agerade och resonerade kring olika didaktiska dilemman de hamnade i med tanke att deltagarna sedan skulle kunna se sig själva och sina egna didaktiska handlingar och val i ett nytt ljus med hjälp av denna visualisering av olika möjliga positioneringar kring det didaktiska dilemmat. Med denna utgångspunkt blir därför den exakta placeringen sekundär då det istället var den ungefärliga positioneringen i fyrfältsdiagrammet och kontrasteringen mot de övriga lärargrupperna som blev det primära i diskussionen. Detta kan leda till reflektion om motiv för och konsekvenser av olika positioneringar i fyrfältsdiagrammen på en mer generell nivå. I analysen under fas I beskrevs olika positioner man kan inta kring de didaktiska dilemman som ansågs mer väsentliga ut en svensk kontext. De möjliga positioner man kan tänkas inta i dessa didaktiska dilemman stod även i relation till positioner i andra didaktiska dilemman. I den initiala analysen under fas II växte fyrfältsdiagram med didaktiska dilemman fram baserat på detta, vilka bildade underlag för fokusgruppsintervju med de svenska deltagarna några månader efter Erasmus+ partnerskapet avslutats. 
I fokusgruppsintervjun med de svenska lärarna, som var den primära datainsamlingen i fas II, diskuterades det utifrån de fyra övergripande spänningar som ansågs mer relevanta ur en svensk kontext med fyrfältsdiagram som underlag. I fokusgruppen reflekterade de svenska lärarna över olika positioner i de didaktiska dilemman som spänningarna gav upphov till i samband studiens reflexiva undervisning.

För att stärka validiteten av de fyrfältsdiagram som skapats under fas II för att fungera som diskussionsunderlag gjordes en återkoppling till deltagarna på de utländska skolorna (Lincoln \& Guba, 1985). Detta gjordes i samband med ett avslutande projektmöte för partnerskapet i maj 2016. Fyrfältsdiagrammen som skulle fungera som diskussionsunderlag i fokusgruppsintervjun med de svenska lärarna presenterades först för lärarna land för land. Deras positionering i respektive didaktiska dilemma i fyrfältsdiagrammen diskuterades och konfirmerades av deltagarna.

Det tål att återupprepas att studiens akademiskt orienterade syfte inte handlar om att beskriva de olika lärargruppernas exakta positioneringar i olika didaktiska dilemman i den reflexiva undervisningen. Istället är lärarnas positioneringar och upplevelser av de olika dilemmana en grund till att synliggöra förgivettagna positioner i olika didaktiska dilemman utifrån en svensk skolkontext. Detta ska i sin tur skapa ett underlag för ett diskussionsverktyg som kan synliggöra olika möjliga positioner kring ett didaktiskt dilemma, samt deras möjligheter och potentiellt negativa konsekvenser. Detta ska hjälpa lärare att koppla samman utbildningens huvudsyften med den konkreta undervisningen så att man ska kunna göra sina didaktiska val i relation till de huvudsyften man väljer att prioritera i den aktuella undervisningssekvensen.

\section{Analysprocess under fas II}

Fokusgruppsintervjun i fas II transkriberades med hjälp av dataprogram för transkribering som tidigare. Parallellt med transkriberingen påbörjades dessutom ett preliminärt analysarbete av data från intervjun. Analysen av data under fas I hade först visat arton 
spänningar och dessa fanns som koder i det kvalitativa analysprogrammet MAXQDA 12 (Release 12.2.0). Ett urval hade gjorts för att fokusera på att fördjupa väsentliga aspekter av de didaktiska dilemman som spänningarna i de svenska lärarnas dilemmatic space orsakar och de didaktiska val som lärarna på de olika medverkande skolorna privilegierar sammanställdes. I analysprocessen av data från den svenska fokusgruppsintervjun under fas II kodades initialt med samma koder från fas I, men det visade det sig att en del av de tidigare identifierade spänningarna innehöll flera didaktiska dilemman. Med grund i de svenska lärarnas diskussioner kring fyrfältsdiagrammens alternativa positioneringar kunde några nya didaktiska dilemman urskiljas i ett växelspel mellan teori och data. Dessa fördes in som koder i analysprogrammet.

Data från de svenska lärarnas diskussioner och reflektioner kring fyrfältsdiagrammen lästes sedan igenom och relaterades dels till resultaten beträffande de svenska lärarnas undervisning i fas 1 , dels resultat beträffande övriga lärargruppers positioneringar. Analysprocessen var ett slags växelspel där först bakgrunden till de svenska lärarnas priviligierade positioner inom studien extraherades ur deras beskrivningar med hjälp av den bakgrundsbild jag har av lärarna och skolan. Under fokusgruppsdiskussionerna behandlades även andra möjliga positioner i de didaktiska dilemmana och de svenska deltagarna diskuterade även möjligheter och eventuella konsekvenser av andra didaktiska val. För att analysera vad som gjorde att de svenska lärarna valde positioner under den undervisningen under studien och vilka potentiella möjligheter och konsekvenser som dessa positioner erbjuder, relaterades data till tidigare teori rörande detta i ett abduktivt förhållningssätt, där jag växlade mellan teori och empiri.

Genom att analysera data från fokusgruppsintervjun under fas II där de svenska lärarna diskuterade utifrån fyrfältsdiagrammen kunde studiens forskningsfråga II besvaras. I diskussionerna belystes de positioner som de svenska lärarna själv intagit i den reflexiva undervisningen, men samtidigt diskuterades även de positioner som de andra lärargrupperna intog i de olika didaktiska dilemmana. I jämförelsen 
med andra positioner i de didaktiska dilemmana kunde deltagarna uppmärksamma förgivettagna val de gjort och reflektera över både möjligheter och eventuella konsekvenser med olika positioner rörande de didaktiska dilemmana. Detta gjordes även genom att de svenska lärarna beskrev alternativa positioner som de själva tidigare har intagit i andra former av undervisning.

\section{Resultat och diskussion av studiens andra fas}

Resultaten från studiens första fas, i form av de olika lärargruppernas positioneringar rörande olika spänningar, kom att fungera som en spegel för de svenska lärarna att använda sig av för att se sig själv och sin egen praktik i. Resultat från diskussioner med de svenska deltagarna som genomfördes i linje med komparativ didaktik beskrivs i denna del av kapitlet. Data kommer primärt från fokusgruppsintervjun som gjordes med de svenska lärarna under denna fas. Dessa lärare reflekterade emellertid även kring sin egen praktik i samband med tidigare fokusgrupper, när de i samtalen erfor övriga deltagares upplevelser av den reflexiva undervisningen. Därför kom primärdata från nämnda fokusgruppsintervju i något fall även att kompletteras med sekundära data från tidigare empiri. Diskussionerna kring de olika spänningarna med deras didaktiska dilemman, och den abduktiva analysen av detta, ledde till att en del didaktiska dilemma modifierades och fokuseras innehållsmässigt. Även nya didaktiska dilemman kunde utkristalliseras ur tidigare identifierade dilemman, såväl utifrån de erfarenheter de svenska lärarna fått genom undervisningen inom EU-projektet som från deras beskrivningar av annan undervisning.

En följd av den tolkande ansatsen och det abduktivt tillvägagångssättet $\mathrm{i}$ analysen var att resultat och diskussion kom att integreras $\mathrm{i}$ en mer berättande stil i denna del av uppsatsen. Resultaten växte fram och forskningslitteratur, teori och kontext bidrog tillsammans till att öka min förståelse av studiens empiri. I resterande del av kapitlet finns därför ingen strikt uppdelning där objektiva resultat presenteras för att sedan diskuteras genom att anknyta till tidigare forskning utan istället kombineras resultat, analys och diskussion i form av en mer berättande text. En konsekvens av den berättande 
stilen blir även att den ordning metadilemmana beskrivs i skiljer sig något från ordningen av de övergripande spänningarnas i förra kapitlet.

I den reflexiva undervisningen framträdde spänningar och lärarna intog olika positioner när de ställdes inför didaktiska dilemman. De svenska lärarna planerade sin undervisning och gjorde sina didaktiska val baserat på deras dilemmatic space och positionerade sig efter verksamhetens regler, normer, värderingar, olika aktörer med olika roller samt invanda handlingsmönster. Detta gjordes till stor del grundat i förgivettagna didaktiska val grundade i tidigare erfarenheter. Det förgivettagna blev inte fullt synligt och medvetet för lärarna förrän positionerna i de didaktiska dilemmana kunde sättas i relation till de alternativa positioner som lärarna på de andra skolorna intog. Studiens andra fas handlade om att synliggöra, diskutera och analysera olika möjliga positioner, speciellt när de svenska positionerna i de väsentligaste didaktiska dilemmana kontrasterades mot andra positioner.

De didaktiska dilemman som fördjupas i detta kapitel visar på att lärare gör didaktiska val efter förgivettagna positioner även i en förändrad form av undervisning. Relaterar man inte sina val till specifika syften för undervisningsaktiviteten riskerar förgivettagna didaktiska val göra att syften kan komma att motverka varandra. I undervisningen fattar förvisso lärarna sina beslut utifrån goda intentioner men om inte handlingarna i klassrummet är kopplade till synliggjorda syften och motiv för den aktuella undervisningen uppstår oundvikligen motsättningar och syfteskonflikter. I detta kapitel behandlas fyra metadilemman inom den reflexiva undervisningen där de svenska lärarna på olika vis hade förgivettagna positioner. Dessa fyra metadilemman bygger som beskrivits tidigare på de fyra övergripande spänningarna från förra fasen, där benämningen på dem omformulerats något.

1. Elevcentrerade eller lärarcentrerade arbetsformer

2. Undervisning mot bildningsmål eller utbildningsmål

3. Om läraren ska vara objektiv, neutral eller ta ställning 
4. Om anpassningar vid muntliga diskussioner ska göras eller inte

Det första metadilemmat är om lärarna låter eleverna ta ett större ansvar för informationsinhämtning och diskussionerna i undervisningen eller om läraren intar en mer aktiv roll angående detta. Detta metadilemma har en tydlig relation till det andra metadilemma som handlar om hur läraren positionerar sig kring vad i skolans läroplan som styr och bör påverka undervisningen mest. Det tredje metadilemmat som fördjupas gäller vilken roll läraren ska ha i de diskussioner kring de kontroversiella frågorna som utgöt den reflexiva undervisningens klimax. I vilken utsträckning läraren ska ta ställning i frågorna, antingen professionellt eller personligt, påverkar elevernas diskussioner och den reflexiva undervisningen på olika vis. Det fjärde metadilemmat som fördjupas berör i vilken utsträckning som läraren ska göra anpassningar för elever som inte självmant deltar aktivt i diskussionerna. Det kan gälla huruvida man ska erbjuda eleverna att uttrycka sig och argumentera skriftligt istället eller att ha gruppdiskussioner där eleverna är nivågrupperade så att även elever som har svårigheter att muntligen uttrycka sig ska få talutrymme.

\section{Elevcentrerade eller lärarcentrerade arbetsformer}

En sak som framstod tydligt i den komparativa analysen var att de svenska lärarna var mer avvaktande i sin lärarroll i samband med temadagarna när deltagande observationer genomfördes. Medan lärarna på de övriga skolorna intog en mer aktiv lärarroll och var den primära förmedlaren av information rörande den aktuella kontroversiella frågan agerar de svenska lärarna mer som handledare åt eleverna. Dessa förväntas samla relevant information själva med hjälp av sina datorer, förvisso med hjälp av en introduktion i ämnet av lärarna. Det ska påpekas att de svenska lärarna i annan undervisning inte har några problem att inta en aktivare roll som klassrummets primära förmedlare av kunskaper och fakta, så ett didaktiskt val gjordes uppenbarligen för denna form av undervisning. När jag själv skapade undervisningsmodellen med de kontroversiella frågorna som lärargrupperna arbetade med under studien hade jag lagt 
förhållandevis mycket tid på att samla in fakta och information med olika aspekter på var och en av de kontroversiella frågeställningarna. Jag benämnde denna översiktliga sammanställning kring frågans aspekter som "comments to the teacher". När jag arbetade med detta hade jag själv tagit för givet att eleverna på egen hand skulle samla in relevant information för att kritisk granska och värdera denna. De övriga deltagande lärargrupperna tolkade emellertid "comments to the teacher" som den informationsbas som de skulle förmedla till eleverna genom en mer traditionell föreläsande lektion. När klassen väl hade denna gemensamma grund fick eleverna ta ställning i frågan och bygga upp argument för sin hållning.

Arbetsform för inhämtande av information under den svenska temadagen

När man jämför hur de olika lärargrupperna genomförde arbetet med de kontroversiella frågorna som skulle behandlas under temadagen framträder skillnader. På skolorna i alla de andra länderna hade man ett upplägg där man tog frågeställning för frågeställning med diskussioner i helklass ledda av läraren. Det var även vid tillfällen uppblandat med diskussioner i mindre grupper, men det var under kortare perioder och resultatet av gruppdiskussionerna följdes upp i en helklassdiskussion.

Under den svenska temadagen arbetade eleverna större delen av tiden i av läraren sammansatta grupper om ungefär fyra elever. Grupperna hade med sig tre eller fyra problemområden innehållande flera frågeställningar som de arbetade med i egen takt under ett långt arbetspass. De olika grupperna kunde i sin tur sedan arbeta med olika kontroversiella frågor och alla elever arbetade inte med samtliga frågor. De olika grupperna tog paus när det passade dem och lärarna gick runt och hjälpte till vid behov, om det fanns frågor vid faktainhämtningen eller om det behövdes inspel i gruppens interna diskussioner kring den aktuella frågan. I slutet av temadagen deltog en representant från gruppen vid en förhandling för att komma fram till en gemensam ståndpunkt för gruppen kring de olika frågeställningarna. Under dessa var lärarna diskussionsledare och intog en mer aktiv roll, vilken behandlas mer längre fram. Man ska emellertid inte 
tolka detta som att de svenska lärarna bedriver all undervisning i form av grupparbete. I den komparativa fokusgruppsintervjun med de svenska lärarna diskuterade de även fördelar med att ha en mer sammanhållen reflexiv undervisning, speciellt om man diskuterar väldigt kontroversiella frågor.

Jag tänker spontant att man gör det i helgrupp där det är läraren som styr. Då kan läraren styra så att man inte hamnar för mycket åt något håll. Gör man det i mindre grupper är det jädrigt svårt, att gå runt och lyssna. Jag tror i så fall att man får välja metod utifrån vilken fråga man ska prata om. (Simon, Sverige)

Den svenska lärargruppens upplägg för temadagen, och även grunderna i studiens undervisningsmodell, prioriterar att eleverna ska utveckla kunskaper kring beslutsfattande genom att de själv ska vara aktiva och ansvarstagande deltagare. Detta framträder ännu tydligare när det svenska upplägget jämförs med övriga temadagar där läraren har en centralare roll som kunskapsförmedlare. De svenska lärarnas didaktiska val grundar sig i en önskan att eleverna ska utveckla förmågor att samla in, granska och värdera information. Dessa förmågor är starkt betonade i Lgr 11 och i och med att den svenska skolans elever sedan några år tillbaka har tillgång till en personlig dator fanns också en självklarhet i att använda dessa för att söka information. De svenska lärarnas intention med sitt didaktiska val är att genom att låta eleverna vara aktiva kunskapssökare och låta dem arbeta självständigt. Därigenom ska de kunna utveckla nämnda förmågor genom ett aktivt arbete. Samtidigt är det en stor utmaning för en elev på högstadienivå att på egen hand hitta fakta kring en kontroversiell fråga och dessutom få syn på de olika aspekter som finns.

Jag var också starkt influerad av en elevcentrerad undervisning i arbetet med den undervisningsmodell som skulle stödja lärarna i sin planering av deras reflexiva undervisning. Som beskrivits ovan sammanställde jag fakta och information i form av "comments to the teacher" och med min relativa expertis behövde jag minst en timme på mig för att sätta mig in i en fråga och belysa olika sätt att se på 
det. Sedan förväntade jag mig i mitt förgivettagande att eleverna, endast med en kort introduktion i ämnet, skulle klara det på egen hand på betydligt kortare tid. I efterhand framstår det som helt orealistiskt, men samtidigt visar det på ett starkt förgivettagande.

Även om det var svårt för de svenska eleverna att hitta relevant information fick de dock betydligt mer träning i att själva söka information och granska den, i jämförelse med de övriga eleverna. Till en liten del fick även dessa elever själva söka information, men det var ändå framförallt läraren som ansvarade för att förmedla olika aspekter av frågeställningen, till stor del utifrån den sammanställning jag gjort. De svenska lärarna reflekterade över sina didaktiska val och synliggjorde dilemmat.

Jag tänker mig också i detta med att eleverna arbetar i grupp och letar fakta själv att det kan väl finnas en poäng i det, men det ställer ännu högre krav på att läraren är en mycket duktig person. Annars blir det som John säger att man sitter i ett grupparbete och läraren blir en handledare som bara puttar på dem, "jobba nu, jobba nu". Jäkligt tråkigt jobb. [...] Det ställer mycket större krav på läraren att intressera eleverna om de [eleverna] sedan själv förväntas jobba med det. Människor som inte vet något om någonting är heller särskilt intresserade av det. Elever letar fakta själv och det är inte på något vis drivande om jag säger till eleverna "idag regnar det, ta reda på varför". Det är inte särskilt intressant om man inte vet något. Berättar jag en hel lektion om varför det regnar och är rolig så kanske det väcker någon i alla fall. (Simon, Sverige)

Potentiella möjligheter och konsekvenser av de svenska lärarnas position kring arbetsform vid inhämtande av information

En annan spänning som identifierades var den kring hur mycket den enskilde läraren förberedde sig kring de kontroversiella frågorna som diskuterades i samband med temadagen. Det var komplexa frågor som diskuterades där en hel del av kunskapsinnehållet delvis låg utanför lärarnas eget ämne. Även då kunskapsinnehållet tillhörde 
lärarens ämne gällde det ibland saker som inte alltid var tydligt framlyfta i ämnets centrala innehåll. I jämförelsen mellan de olika lärargrupperna var det tydligt att de svenska lärarna överlag hade lagt betydligt mindre tid på att läsa på kring de delar av frågeställningarnas innehåll som låg utanför deras normala kunskapsområde. Det var också något de själva tillstod och det finns också en relation mellan denna position och deras val att inta en mer handledande lärarroll och låta eleverna ta ett större eget ansvar i arbetet. När lärarna inte själv skulle ansvara för att förmedla relevanta fakta till eleverna och inte heller behövde inta någon expertroll fanns det utrymme för dem att ta lite lättare på förberedelserna. I jämförelsen med övriga lärargrupper, vilkas undervisning var mer lärarcentrerad, blev de egna förberedelserna viktigare för dem.

I: Finns det något samband mellan att man inte förbereder sig så mycket och att eleverna söker kunskap själv och att det inte primärt är läraren som förmedlar kunskaperna i sådana här diskussioner?

Simon: Annars tror jag att det absolut finns ett samband precis som du säger. I Polen och Italien är det förhållandevis mycket lärarstyrd tid och där förväntas läraren ha kunskap och jag tror att det blir en obehagskänsla om läraren går in i klassrummet om den inte känner till. Sedan är de inte så vana vid att ungarna har några speciella förkunskaper och bryr sig kanske inte heller om det och det är kanske inte så viktigt. Här är det jag som vet och jag som förmedlar till er. Då är det till att man vet för annars blir det ett problem. Jag tror absolut att det kan finnas ett samband.

De svenska lärarna beskrev visserligen att även de önskade att de kunde bottna i faktakunskaper kring de ämnen de diskuterade, men ansåg inte att det var några problem med att erkänna för eleverna om de saknade kunskaper kring något. I samband med Erasmus+ partnerskapets tre utbyten genomfördes förhandlingar där elever från respektive deltagande land gemensamt diskuterade och argumenterade kring de aktuella kontroversiella frågorna. Efter förhandlingen som rörde samhällsdilemman fanns konsensus bland alla de 
lärare som var med att det ofta var de svenska eleverna som lyckades övertyga de andra deltagarna och så att säga "vann" diskussionen. Lärarna menade dock att det inte berodde på att de svenska eleverna var de som hade de bästa och djupaste kunskapsargumenten, utan snarare på att de helt enkelt var skickligare på att förhandla. Dessa diskussioner genomfördes på engelska och givetvis spelar elevernas förmåga i det engelska språket in. De svenska eleverna som deltog inom studien hade visserligen goda muntliga förmågor i engelska språket, men samtliga som representerade de övriga skolorna i förhandlingarna var bra på engelska.

De svenska lärarna fick spegla sina egna positioner kring arbetsformen i de övrigas lärargrupper beträffande hur eleverna diskuterade i samband med internationella förhandlingarna elever emellan. I samband med detta ringades det didaktiska dilemmat in kring hur aktiv läraren bör vara som faktaförmedlare i den reflexiva undervisningen.

John: Jag kände ju att Piotr i Polen i mångt och mycket hade preparerat eleverna. Dels hade de Roberts ordval i engelska, de hade ett väldigt utvecklat ordval. Där kunde man utan vara underrättelsetjänstofficer se att han hade en inverkan helt enkelt. Där reagerade jag lite ryggmärgsmässigt och tycker att det dödar deras spontanitet och deras entreprenöriella förmåga. Då sitter ju vuxenvärlden med svaren, läraren sitter i katedern med svaren.

I: Kan det finnas något positivt för de eleverna om de fått hans förmedling?

John: Ja, om man hade gått vidare och om man hade haft ett sant mångstämmigt klassrum - "Så här är det idag, men vi pratar om en okänd framtid", som det faktiskt rörde sig om. Skulle man då kunna gå vidare från de här fakta som jag presenterar och "Vad säger ni?". Men det känns som de stannade mycket vid den fina förklaringen som givits av läraren.

I: Om vi tar era elever som bevisligen hade sina egna åsikter och 
kunskaper med sig till förhandlingen, men kanske inte så djupa. För- och nackdelar med det?

Mikael: Jag tror kombon skulle vara det perfekta. För jag tror att de var väldigt väl förberedda [elever från Italien och Polen] men när de fick en följdfråga som inte var förberedd föll de igenom lite, dels på grund av språket men även på grund av det andra. Jag tror också att vi la för lite tid på fakta, vi hade inte den tiden eller vad det nu är.

John: Sen och andra sidan får vi också säga att upplägget för temadagen var sådant att temadagen hade vissa frågeställningar som var förutsättningslösa. Vi hade väldigt lite, men visst vi skulle kunnat bygga upp det och tagit egna initiativ och varit entreprenöriella själva och tittat på de här frågeställningarna innan.

Om man tänker sig ett kontinuum mellan elevcentrerad och lärarcentrerad undervisning kan båda extrempositionerna ha sina konsekvenser. Positionerar man sig i ena änden kan man tänka sig att det innebär att eleverna verkligen ges förutsättningar för att få relevanta kunskaper om de ämnen som de aktuella kontroversiella frågeställningarna berör, tack vara att läraren intar en aktiv roll i förmedlingen av detta. Samtidigt finns risk att det därmed inte skapas tillräckligt med utrymme för eleven att själv undersöka information och därmed utvecklas i den specifika praktik som det är att söka och granska information och ta egen ställning. I kontinuumets andra ände är just dessa förmågor centrala, men om läraren är alltför passiv och inte säkerställer att eleverna får tillgång till tillräckligt med bra fakta i frågeställningen riskerar deras argument bli grunda och diskussionerna handlar då mer om allmänt tyckande än genomtänkt och underbyggt resonerande.

För min del och i vår undervisningskultur, får vi inte riktigt lov att... vi ska verka som genom Guds hand, vi ska arbeta genom eleverna. Vi låter dem vara aktiva och göra saker, men samtidigt blir vi sedan besvikna på resultaten. "Eleverna skulle ju kunnat förberett sig bättre och skulle kunnat underbygga sina argument 
bättre". Men detta är ju faktiskt mitt fel för jag skulle kunnat agerat annorlunda, så det är en lite schizofren situation. (John, Sverige)

De svenska lärarna menade att deras elever var duktiga på att argumentera och diskutera, men oftare handlade det mer om att tycka och tro än att underbygga sina påståenden med faktagrund. Detta kan tolkas som att de positionerat sig alltför nära en extremt elevcentrerad undervisning på de didaktiska dilemmats kontinuum i samband med temadagens undervisning. Rundgren (2006) menar att i ett klassrum där inte förmedlande undervisning åtminstone till en viss del förekommer finns risk att de elever som har haft möjligheter att tillägna sig kunskaper utanför skolan privilegieras. Han påpekar dock att det inte räcker med att kunna beskriva betydelsen av termer och begrepp, utan för att dessa ska bli meningsfulla måste man förstå hur begreppen används, i vilka sammanhang och hur dessa hänger samman med andra saker. Detta görs genom att aktivt deltaga i ett sammanhang och iaktta och samverka med någon som behärskar området.

Detta dilemma är sannerligen inget nytt och redan Platon uppmärksammade detta som ett slags pedagogisk paradox (Uljens, 2001) som i detta sammanhang kan beskrivas som att det bästa sättet att lära sig saker visserligen kan vara att själv hitta denna kunskap i en praktik - men för att kunna finna den kunskapen behöver man ha viss kunskap sedan innan, för annars hittar man inte den nya kunskapen. Billig (1988) menar att man som lärare hamnar i ett ideologiskt dilemma och måste balansera en demokratisk lärarroll mot en mer auktoritär. I undervisningen ska läraren förmedla kunskaper till eleverna samtidigt som läraren även ska framkalla eget kunskapande hos eleven.

Det finns en fara $\mathrm{i}$ att man $\mathrm{i}$ en reflexiv undervisning låter eleverna helt själva vara de som aktivt letar fakta och information, som bygger upp argument, vilka de sedan lägger fram, och argumenterar kring i diskussioner med andra elever. De kunskaper och det kunnande som eleverna får med sig från denna läraktivitet kan troligtvis 
vara beständiga, men om de inte får med sig några kunskaper i processen från en expert, riskerar de att missa en del andra kunskaper och annat kunnande på vägen. Om man som lärare har en alltför tydligt förmedlande roll och om argumentens ämnesinnehåll främst hamnar i fokus är det också problematiskt. Eleverna får förvisso tillgång till väl underbyggda argument och faktakunskaper, men har kanske inte själva varit delaktiga i att bygga upp argumenten och inte heller fått träning i dessa förmågor. Det finns risk att elevens argumentation ändå inte når fram till en mottagare då den inte är autentisk och eleven inte helt förstått problemställningen.

När de svenska lärarna speglar sig mot övriga deltagande lärare för att ge en förklaring till de didaktiska valen kan de se flera potentiellt negativa konsekvenser med sina positioner. De menar emellertid att de positionerats dit genom att det sedan 90-talet skett en form av "indoktrinering" av de svenska lärarna där en mer förmedlande lärarroll har setts som förlegad och lärare som inte arbetat elevaktivt och handledande också drabbats av en negativ löneutveckling. Lärarna på de övriga skolorna beskrev sig endast ha ringa erfarenheter av en undervisning där eleverna arbetar självständigt och där eleverna ges ett större ansvar för sitt eget lärande. I och med denna erfarenhetsbakgrund blir deras positioneringar i form av en mer förmedlande och styrande lärare naturlig. När de svenska lärarna planerade temadagen byggde de på sina erfarenheter och gjorde sina didaktiska val efter dessa när de såg likheter med tidigare undervisning liknande denna. I diskussionerna i den svenska fokusgruppen framgår det att de svenska lärarna under partnerskapet gjorde sina didaktiska val mer eller mindre oreflekterat och följde en förgivettagen modell över hur den reflexiva undervisningen ska se ut.

\section{Arbetsform i diskussionerna - helklass eller grupp}

Eleverna arbetade emellertid mestadels varken enskilt eller i helklass under den svenska temadagen utan det rörde sig mestadels om grupparbete. Granström (2007) skriver att lärare ofta har dåliga erfarenheter av grupparbete och lyfter fram två tänkbara orsaker till de svårigheter som uppenbarligen finns med denna arbetsform. För det första menar han att grupparbete ofta egentligen är olika former 
av parallellt individuellt arbete, där man på olika vis i slutet sammanställer de olika elevernas arbete. Det är alltför sällan konjunktiva uppgifter (Steiner, 1972), alltså uppgifter som förutsätter alla gruppmedlemmars deltagande för att den ska kunna genomföras. Den andra som Granström pekar på som kan skapa svårigheter är den gruppdynamik som ofrånkomligen uppstår mellan gruppmedlemmarna när de utforskar sin egen identitet och andras värderingar och åsikter. Dessa processer stjäl fokus från arbetet med den uppgift läraren gett gruppen. Ekborg m.fl. (2012) konstaterar dessutom att elever ofta saknar träning i grupparbete, samtidigt som lärarna tar för givet att eleverna kan detta. Granström (2007) hävdar vidare att lärare behöver lära sig att hantera dessa saker för att kunna ta tillvara den potential till lärande och utveckling som finns med grupparbete. När eleverna arbetar tillsammans i grupp i arbetet med kontroversiella frågor kan de lära av varandra och fungera som stöd för varandras lärande, vilket gör att den sammanlagda kunskapspotentialen är större än varje enskild del. När grupperna fungerar innebär gruppens litenhet, i jämförelse med helklassen, att varje elev ges betydligt mer talutrymme, och möjlighet för engagerade diskussioner skapas där alla får chans att uttrycka sin egen åsikt.

Grupparbete och eget arbete bygger på andra principer än en traditionell helklassundervisning. Här är det främst elevens eget sökande efter kunskap som är drivkraften och det som för utvecklingen framåt samtidigt som det för läraren innebär en mer handledande och stödjande roll (Arnqvist, 2010). Individualisering är något som länge betonats i våra styrdokument och eget arbete var en arbetsform som växte fram i den svenska skolan med start på 1970-talet, men som fick sitt stora genomslag under andra halvan av 1990-talet (Carlgren, 2015). I samband med ökat fokus på eget arbete har andelen grupparbete minskat i skolan till en liten andel av undervisningstiden, trots att denna form har en omfattande spridning $i$ arbetslivet (Arnqvist, 2010). På studiens svenska skola kom alltså under en period på slutet av 1990-talet och början av 2000-talet mycket fokus hamna på att arbeta med ett individanpassat arbetssätt. Eget arbete innebär i stora drag att eleverna själva både planerar och ansvarar för delar av sitt arbete och i undervisningen arbetar 
de sida vid sida, men ofta med olika ämnen och uppgifter. Framväxten av eget arbete i skolan härleder Österlind (2010) även till införande av datorer i skolan och när det finns en dator per elev krävs en flexiblare och mer individuell organisation av undervisningen för att utnyttja tekniken till fullo.

Österlind (2010) påpekar att en mer individuell undervisning inte är en företeelse som kan ses i svart eller vitt utan det krävs ett medvetet, nyanserat och måttligt bruk av den. I linje med tanken om undervisningen som ett dilemmatic space där olika positioneringar både kan medföra för- och nackdelar kan man se att det mer individuella arbetssättet som fanns under den svenska temadagen underlättar för individen att ställa egna frågor till läraren. Samtidigt blir det absolut nödvändigt att alla individer och alla grupper verkligen ställer frågor till läraren för att få del av kunskaper eller rätta till missförstånd. Detta till skillnad från traditionell helklassundervisning där det är ganska sannolikt att någon annan elev ställer den fråga man själv hade. En elev kan därmed få svar på frågor som den har utan att själv behöva ställa dem.

I jämförelse mellan temadagen på den svenska skolan och på de övriga var den svenska temadagen mindre dynamisk. Vid de övrigas temadagar växlades det mer fram och tillbaka mellan diskussioner i helklass och i mindre grupper, även om helklassen dominerade. Växlingarna skapade dock förutsättningar för att idéer korsbefruktades och diskussionerna tog nya och lite oväntade vändningar.

\section{Arbetsform för diskussioner under den svenska temadagen}

De svenska elevernas arbetsresultat under temadagen berodde en hel del på hur själva gruppen fungerade. De grupper som var företagsamma tog hjälp av läraren eller andra i klassen för att ta sig vidare, till skillnad från grupper som var mer tillbakadragna eller av olika anledningar inte förstod att de behövde hjälp att ta sig vidare i arbetet. Dessa grupper lyckades aldrig fördjupa frågeställningarna, utan de höll sig i argumenten antingen till de aspekter på frågan som de snappat upp under lärarens introduktion eller till mer allmänt tyckande som de hade med sig sedan tidigare. Även om det var en större 
utmaning för de svenska eleverna att skapa fördjupade argument då dessa hade stort eget ansvar för faktainhämtandet, hade de dock fått ordentligt med tid under temadagen för att hitta ytterligare information att använda sig av. Lindahl (2016) visar att mycket i gruppdiskussioner kring samhällsfrågor handlar om att eleverna bara uttrycker sina egna åsikter och inte går vidare i diskussionen. Lindahl menar att eleverna behöver hjälp av läraren med att bli mer öppna för andras åsikter, men också lärarstöd så att de bättre kan uttrycka och motivera sina egna ståndpunkter.

Potentiella möjligheter och konsekvenser av de svenska lärarnas position kring dominerande arbetsform för diskussioner

De svenska lärarna gav eleverna en frihet i sitt upplägg av temadagen och elevgrupperna ansvarade själva för sin arbetstakt med elevuppgifterna och för att hinna med det som läraren ville. Österlind (2010) pekar på en motsägelse angående att elever ges stort eget ansvar för arbete i undervisningen. Samtidigt som det kan vara bra för att utveckla elevernas självdisciplin skapar denna frihet också möjligheter att skjuta upp saker. De svenska lärarna diskuterade att deras position i form av att eleverna arbetade till stor del gruppvis i längre arbetspass med eget ansvar synliggör en prokrastineringsproblematik hos en del elever. Denna visar sig i form av att detta egna ansvar att planera sin tid gör att en del skjuter upp det som de egentligen ska göra, och prioriterar att diskutera andra saker. I och med att eleverna satt utspridda i grupper med lärarna roterande runt som handledare, inbjöd detta till att fokus hamnade på annat för någon elev. De svenska lärarna antar att det finns psykologiska faktorer bakom, men föreslår även att betygssystemets utformning inbjuder till att eleverna skjuter saker framför sig i svenska skolan. Lärarna beskriver det stressande då de upplever att de inte kan sätta någon deadline för eleverna som sista dag att visa upp det som krävs för olika betyg. Istället upplever lärarna att eleverna i princip har fram till sista dagen i grundskolan på sig att lämna in och visa upp kunskaper, vilket en del utnyttjar. Samtidigt känner lärarna av ett yttre tryck genom att det är deras ansvar att påminna elever så att de blir klara med sakerna, lämnar in arbeten och visar upp kunskaper. 
Annika: Alltså jag tycker att det är så här att nu vet vi att alla elever får hålla på in i det sista och det är olika ämnen. I NO är det vissa delar man ska ha checkat av, medan i andra ämnen är mer bara att man spär på. Jag tycker också så att det inte ska ligga på mig att jag ska ligga och jaga. Varför känner jag att jag måste jaga dessa. det borde vara klart från ledningen att har de inte gjort det och du sagt till och skickat ett mejl och de inte lämnat in - sätt ett F. "That's it." Man borde känna det - tvärt om så har man den piskan på att godkänna allihop, eller?

Mikael: Jag håller med dig rätt mycket. Sedan tror jag att det finns ett systemfel också. Om man ska göra en grej är det rätt skönt att veta nu ska jag göra det "på tisdag". Men när vi har det här systemet där det bygger på kunskaper bla bla bla, men har du inte gjort det på tisdag så får du lämna in det på onsdag eller torsdag. Det kan inte vara bra att ha det så och det kan inte skolledningarna påverka utan det är ju Skolverket. Från början när jag jobbade här var det ju var det inlämning en dag och de inte var färdiga kunde de max få ett $G$, sedan när de lämnade in det. Det är en helt annan tydlighet i detta

Ser man till det didaktiska dilemmat kring hur man ska fördela tiden i en reflexiv undervisning mellan arbete i helklass och i grupper alternativt enskilt arbete, var den svenska positionen mer åt det senare. Detta kan innebära att alla elever erbjuds ett lärande genom deltagande i en praktik och där den lilla gruppen ger möjlighet för alla att få talutrymme, både tillsammans med övriga i gruppen och med läraren. Det är dessutom en arbetsform där eleverna styr sig själva och därigenom utvecklar förmågan att ta eget ansvar. På samma gång förutsätter detta att alla elever också har kapacitet att ta just detta ansvar. Även om grupparbetet under den svenska dagen fungerade på ett bra sätt där eleverna byggde upp argument och diskuterade de kontroversiella frågorna de tilldelats uttryckte de svenska lärarna att de inte riktigt var nöjda med resultatet. Eleverna hade inte fördjupat sig och hittat olika aspekter kring frågan i den utsträckning som lärarna hoppats på. Samtidigt som de svenska lärar- 
nas upplägg innebar att de kunskaper eleverna utvecklade under temadagen var grundare än lärarna förväntat sig rent innehållsmässigt, gavs eleverna chansen att verkligen delta i en praktik kring både ställningstagande och beslutsfattande. Detta innebar att de svenska eleverna kunde utveckla andra kunskaper och förmågor jämfört med om arbetsformen skulle präglats mer av lärarförmedling och helklassdiskussioner. I det didaktiska dilemmat gällande i vilken utsträckning man ska välja arbetsformer där eleverna ges större ansvar gäller det som lärare att relatera sin positionering och sitt didaktiska beslutsfattande efter vilket syfte man prioriterar för den aktuella undervisningen.

\section{Undervisning mot bildningsmål eller utbildningsmål}

Hur läraren positionerar sig, och positioneras, i didaktiska dilemman rörande arbetsform har relationer till hur man positionerar sig beträffande läroplanens olika syften och mål samt vilken vikt som läggs vid att testa av denna form av kunskaper vid prov, både lärarens egna och nationella prov. Vad gäller spänningar kopplade till skolans styrdokument finns dessa på systemnivå. Uttolkningar av styrdokumenten på skolnivå positionerar sedan lärarna, snarare än att läraren själv positionerar sig. Att alla behöver några grundkunskaper i skolans olika ämnen kan säkerligen de flesta vara överens om och även om att allt fokus inte ska läggas på förmedling av påståendekunskaper. Samtidigt är denna form av kunskap enkel att pröva vilket gör att man kan förledas att tro att det därför är ett bra sätt att utvärdera elever. Om man använder prov som främst prövar elevernas påståendekunskaper så kan man anta att en mer förmedlande undervisning blir vanlig, eftersom denna undervisningsform ses som det effektivaste sättet att på kort sikt få elever att lyckas.

Undervisningen i studien var ämnesövergripande, innehöll många muntliga aktiviteter och hade ett kunskapsinnehåll som inte alltid höll sig inom en kanon av påståendekunskaper beskriven i centrala innehåll. Undervisningen tog vidare in etiska och sociopolitiska aspekter samt syftade till att skapa utrymme för eleven att ta egen ställning. Alla dessa beskrivna aspekter av en reflexiv undervisning är varken enkla att formulera i kunskapskrav eller för den delen att 
bedöma betygsmässigt. Vad gäller konkreta didaktiska dilemman rörande bedömning som uppstår i en reflexiv undervisning var detta inget som var i fokus för studien och det finns inte utrymme att här fördjupa dessa spänningar. Studiens svenska lärare relaterade upprepade gånger sina positioneringar i andra didaktiska dilemman till just spänningar beträffande bedömning och betygssättning. Detta pekar på den komplexitet som finns i undervisningen och på att läraren i klassrumsvardagen måste balansera rollen som kunskapsförmedlare med en roll som utvärderare och betygssättare. Dessa två verksamheter har delvis olika syften, varför det kan uppstå motsättningar mellan dessa.

\section{Bildning och utbildning i läroplanen}

Carlgren (2015) beskriver en skillnad mellan bildning och utbildning genom att koppla samman utbildning med att man tillägnar sig kunskaper att använda i olika sammanhang, medan bildning handlar om att förändra och förädlas till självständiga, tänkande och reflekterande människor. Till skillnad från bildning har utbildning en specifik början och ett specifikt slut och då behöver utbildningen utvärderas. Carlgren menar att man inte kan mäta eller utvärdera bildning utan i en skola för bildning ska inte mätningar få lov att störa bildningsprocessen, vilket hon menar är fallet i dagens skola. Carlgren menar att det i Lgr 11 är de övergripande målen och riktlinjerna i läroplanens andra del samt målen uttryckta som förmågor i respektive kursplans syftestext som är bildningsmålen medan kunskapskraven relaterade till ämnenas centrala innehåll utgör utbildningsmålen. När det gäller skolans demokratiuppdrag i form av att utveckla elevernas förmågor kring att argumentera och kritiskt granska pekar Andrée och Lundegård (2013) på ett paradoxalt förhållande mellan läroplanens allmänna delar och kursplanerna i naturvetenskapliga ämnen. Samtidigt som läroplanens bildningsmål betonar att varje enskild elev ska ges möjlighet att finna sin unika egenart ska läraren bedöma eleverna efter utbildningsmålen, vilka är i form av kursplanernas kunskapskrav där bedömningen görs efter naturvetenskapliga ramar. De menar att risken finns att betoning hamnar på utbildningsmålen och att eleverna fostras till konsensus 
och följer förutbestämda normer, istället för att utvecklas till individer i frihet och tanke vilket bildningsmålen kring demokrati strävar mot.

\section{Positioneringar mellan bildningsmål och utbildningsmål}

Den reflexiva undervisningen innefattar både utbildningsmål och bildningsmål. Vad gäller utbildningsmål kopplade till den reflexiva undervisningen i studien betonar flera ämnens kunskapskrav i nuvarande läroplanen att eleverna ska undersöka och diskutera omvärldsfrågor ur olika aspekter, granska och använda information, skapa underbyggda resonemang, argumentera och bemöta åsikter. Utöver detta har varje kontroversiell fråga ett ämnesinnehåll och i denna studie gick det att göra kopplingar till centrala innehåll i flera ämnen, även om frågeställningen vid en första anblick indikerade detta. Förutom att innehålla utbildningsmål för eleverna att uppnå blir den reflexiva undervisningen också en del av en mer övergripande bildningsprocess med fokus på Lgr 11:s övergripande normer, värden och kunskaper. Avgörande för denna undervisning var också att sträva mot bildningsmålen i läroplanen genom att det skulle finnas möjlighet för eleverna att bilda sig egna ståndpunkter, och om de skulle vilja också aktivt ta egen ställning, beträffande dessa kontroversiella sociopolitiska frågor. Härigenom arbetar man i den reflexiva undervisningen även med att genomföra det demokratiuppdrag skolan har.

I den ideala skolan ska bildningsmålen styra planeringen av undervisningen där förmågor utvecklas genom det centrala innehållet. Utbildningsmålen, uttryckta i kunskapskraven, används sedan för att bedöma eleverna (Carlgren, 2015). För att detta ska realiseras behövs både förutsättningar i styrdokument och manövreringsutrymme för läraren att göra detta. De polska och de turkiska lärarna i studien beskrev sig positiva till en undervisning mer inriktad mot bildningsmål, men med en läroplan med omfattande centralt ämnesinnehåll och nationella tester som prövar främst påståendekunskap positionerade lärarna sig så att deras undervisning i stor utsträckning fokuseras på ämnesinnehåll med tonvikt på mätbara kun- 
skaper. Trots att de, och inte minst deras elever, hade positiva erfarenheter av denna form av mer bildningsinriktad undervisning medgav de att de inte skulle ha möjlighet att undervisa på detta sätt alltför mycket i framtiden. Inte för att de inte ville, utan de uppfattade det som att en reflexiv undervisning var tidskrävande och skulle ta tid från traditionell undervisning mot utbildningsmålen. Deltagande lärare från Kroatien och Italien illustrerade emellertid att även traditionen har stark påverkan på hur läraren positionerar sig beträffande att undervisa mot utbildningsmål eller bildningsmål. Båda dessa lärargrupper beskrev att deras läroplaner gav utrymme för en mer bildningsorienterad undervisning. Det beskrevs också att de nya nationella proven i Italien inte längre bara var inriktade på faktakunskaper, utan prövade mer av elevers kompetenser. Trots möjligheterna beskrev lärarna att andra saker gjorde att en mer traditionell och utbildningsmålsinriktad undervisning dominerade. Orsakerna till denna förändringströghet var flera och sammankopplade och berodde delvis på lärarna själva och på närsamhällets förväntningar av vad undervisningen ska innehålla, men bidragande orsaker fanns även i praktiska och socioekonomiska utmaningar.

I en komparativ analys jämfördes studiens svenska lärare med de övriga deltagarna kring hur lärarna upplever att läroplan och nationella prov positionerar läraren på ett tänkt kontinuum mellan en undervisning mot bildningsmål eller mot utbildningsmål. Överlag kan sägas att de svenska lärarna inte känner sig i närheten så starkt positionerade som exempelvis de polska lärarna utan de upplever att Lgr 11 innehåller viktiga bildningsmål och de har utrymme att arbeta med en variation av arbetsformer, exempelvis en reflexiv undervisning. Detta även om de kontroversiella frågorna inte helt motsvarar något i centralt ämnesinnehåll och att ämneskunskaper som berörs troligen inte kommer dyka upp i ett nationellt prov. Återkommande berättar de emellertid att de känner att Lgr 11:s införande, vid sidan om ett större fokus på jämförelser av resultaten på de nationella proven och betyg, har gjort att de allt mer arbetar mot utbildningsmål och nationella prov. De menar exempelvis att man på ämneskonferenser jämför olika lärares procentuella differens mellan 
nationella prov och slutbetyg och därmed har ett slags kollektiv bevakning uppstått.

Någonstans tänker jag på, jag menar du ser pärmarna där de är fulla av stoff som omfattar 7-9 och sådant som jag ska bedöma och i slutet, skolan idag är mycket mer inriktade mot de nationella proven än tidigare. Den tendensen har inte avmattats utan stärkts. Vi jobbar numera som vi uppfattade britterna, vi jobbar mot nationella och checka av "har jag rätt betyg på Pelle och Stina?". (John, Sverige)

\section{Det nya bedömningsparadigmet}

Även om bedömning inte var en del av studiens undervisningsmodell framgår det tydligt av samtal och fokusgruppsdiskussioner med de svenska deltagarna att just frågor kring bedömning av en reflexiv undervisning, speciellt när eleverna ska skapa egna argument och diskutera dem muntligt, är något som lärarna anser är viktigt. När samtal kom in på annan undervisning där det fanns liknande inslag av muntliga diskussioner pekade de svenska lärarna på att det då var svårt att göra betygsbedömningar av alla elever i klassen. Detta menade de bidrog till att de använde muntliga övningar i mindre utsträckning i sin undervisning än vad man egentligen skulle vilja. Även om det var utvecklande för eleverna så gjorde bedömningsproblematiken att omfattningen av muntliga inslag i undervisningen begränsades av en del lärare. Av vad de svenska lärarna berättade kan man konstatera att bedömning spelar en central roll för deras didaktiska val och är med som en betydande del i deras undervisningsplanering. När de nämner de utmaningar som finns med bedömning är det vidare en bedömning för att samla in underlag för en framtida betygssättning de menar. Att göra formativ bedömning i samband med de muntliga delarna av den reflexiva undervisningen upplevde de inte som någon svårighet, även om de inte gjorde det i någon större utsträckning under temadagen i alla fall.

Annika: Jag tyckte det var jättebra när jag var runt och lyssnade på dem och jag tycker att många är väldigt duktiga och glada för att diskutera. Där var ju någon elev idag som man riktade sig mot 
som kom med bra grejer, som man inte hört så ofta. Sen var det som vi pratade om innan att bedömningen är det som jag tycker är svårast. Jag hade kunnat köra sådant här jättemånga gånger.

I: Vad säger ni om bedömningen?

Mikael: Den är ju inte enkel att göra en bedömning på detta så här när man går runt om man ska se det ur ett rättssäkerhetsperspektiv, men man kanske ska se det som ett led som sedan leder till en annan bedömning tror jag istället. De får en annan förmåga så att de lättare kan förklara vidare. Det är fina, fina ordet formativ. Jag håller med dig, bedömning är inte lätt.

Annika: Alltså, man skulle kunna valt ut en skriftlig fråga tänker du?

Mikael: Det skulle man kunna göra utifrån det som de har jobbat med om man vill ha det som en bedömning.

De svenska lärarna i studien hade fått väldigt mycket fortbildning och utvecklingsarbete med betygssättning och bedömning åren kring att Lgr 11 infördes. Jönsson (2016) skriver att grundtankarna i det han beskriver som "nya bedömningsparadigmet" var att främst stödja elevernas utveckling mot skolans långsiktiga mål. Bedömningen var till för eleven och att stödja den att ta ansvar för sitt eget lärande. I stället för fokus på detta menar Jönsson att "pseudo-formativ bedömning" har uppstått i skolans praktik. I denna har bedömningen för lärande reducerats till metoder för att uppnå höga provresultat, exempelvis genom att läraren ger ett betygsomdöme per provuppgift och att bedömningen primärt syftar till att "bocka av" utvalda och isolerade delar av kursplanernas kunskapskrav.

När svenska lärare diskuterade och reflekterade kring den reflexiva undervisningen de arbetade med inom studien uttryckte de återkommande att det fanns utmaningar beträffande att utföra en vad som de beskrev som "rättssäker" bedömning av eleverna. Det gällde att få en likvärdighet när det är svårt att veta vilken elev som gjort vad 
då de arbetar i grupp. De pekade även på nackdelen att inte alla elever får samma chans att visa upp sina kunskaper när arbetet till stor del är muntligt. I frågeställningarna i samband med intervjuer och samtal gjordes ett medvetet val att inte definiera bedömning närmare. Genomgående under samtalen med de svenska lärarna kring bedömning blir ordet bedömning för dem synonymt med en bedömning just för att bocka av i kunskapskraven. En av de tänkbara förklaringar som Jönsson (2016) ger till att pseudo-formativa praktiker har uppstått är att det finns starka summativa strukturer i form av betyg och nationella prov. Det finns därför risk att den tänkta formativa bedömningen blir en form av kontinuerlig summativ bedömning där allt eleven presterar räknas in i ett framtida betyg.

Hultman (2015) menar att formativ bedömning har integrerats in $\mathrm{i}$ skolpraktiken som användandet av olika metoder och tekniker i klassrummet, snarare än som en djupare förståelse hos lärarna för forskningen bakom teknikerna och metoderna. Hultman menar att när forskning förs in i det etablerade verksamhetssystem som skolan kommer forskningsresultaten oundvikligen förändras och anpassas efter de aktörer och regler som finns samt efter hur arbetsfördelningen ser ut på skolan. Uppkomst av en pseudo-formativ bedömning kan därför ses i ljuset av det som Engeström (2008) beskriver som runaway objects. Han menar att arbetslivet allt mer domineras av det som kan beskrivas som skenande objekt och som finns både i stor och liten skala. Dessa kan karakteriseras av något som börjar som små idéer eller problem som efter hand växer utom kontroll och då kan skapa oönskade och okontrollerbara sidoeffekter. På samma sätt som med formativ bedömning kan dessa ursprungligen vara nyttiga innovationer, som operativsystemet Linux med sin öppna källkod eller det webbaserade uppslagsverket Wikipedia. Men när de växt sig större står de inte längre under några enskilda individers kontroll och detta kan innebära oanade konsekvenser. Skenande objekt kan också vara farliga som finanskriser och klimathot och dessa har ofta genererats av globala marknadskrafter och girighet, snarare än omtanke om mänskligheten och planetens bästa. 
Studiens svenska lärare började samtliga att arbeta som lärare i samband med att Lpo 94 var ny och det har varit under denna läroplan som lärarna formerades under de första arbetsåren. Sundberg (2015) menar att Lgr 11 växte fram som reaktion till otydligheten i målbeskrivningarna i Lpo 94 och det stora professionella ansvaret som lades på läraren. Sundberg menar att i denna resultatfokuserande läroplan finns ett starkt fokus på bedömning av mätbara mål och detaljstyrning i form av centralt innehåll och kunskapskrav. De svenska lärarna i studien tog alltså del av fortbildningssatsningar för en formativ bedömning under slutet av 00-talet och i början av 10talet. Det förefaller vara så att diskursen om vikten av bedömning fortfarande finns kvar bland lärarna i studien, men det verkar som fokus har förskjutits från formativ bedömning till summativ bedömning.

Om stor vikt läggs vid att det som eleverna gör på lektionerna ständigt ska gå att stämma av mot kunskapskraven ligger det nära till hands att kunskapskraven blir grund både för planering och bedömning av undervisningen. Studiens svenska lärarna förefaller hamnat i en sådan pseudo-formativ praktik och positionerats dit av de summativa strukturer i Lgr 11. Dessa summativa strukturer i form av de framlyfta kunskapskrav framträder dessutom ännu tydligare när denna läroplan sätts i kontrast mot den föregående (Sundberg, 2015) och man kan bättre förstå studiens svenska lärares förhållande till kunskapskraven utifrån denna kontrast. Lärarna har format sin profession i Lpo 94, men en brist som den hade var otydligheten kring summativ bedömning. Det är förståeligt att lärarna satt stor tilltro till den nya läroplanens kunskapskrav med till synes tydliga matriser som dessutom kändes igen från fortbildningar kring bedömning.

Carlgren (2015) pekar på att Lgr 11:s ideala upplägg, där undervisningen planeras genom att förmågorna appliceras på det centrala innehållet och varefter eleverna bedöms med hjälp kunskapskraven, i många fall har kommit att utföras tvärtom i praktiken. Hon menar att fokus på synligt lärande, elevansvar och formativ bedömning har påverkat lärarna så att de positionerat sig så att undervisningen mer 
planeras efter utbildningsmålen i form av kunskapskraven, än utifrån bildningsmålen i form av förmågorna. I denna form av baklängespedagogik är inte själva lösandet av uppgifterna det som blir det centrala, utan det viktiga är att eleven i arbetet med uppgiften ska kunna visa tecken på sitt kunnande. Carlgren menar vidare att om eleverna bara tränas på att visa tecken på sitt kunnande, istället för tränas för att lösa den aktuella uppgiften finns det en risk att det blir en imitation av kunnande hos eleverna istället för riktigt kunnande.

Potentiella möjligheter och konsekvenser av de svenska lärarnas position kring bildning och utbildning

I lärarens praktiska arbete i klassrummet framträder ett didaktiskt dilemma kring att balansera användandet av utbildningsmål och bildningsmål och att få en fungerande blandning vid varje givet undervisningstillfälle. Som beskrivits ovan är dessa två typer av mål för undervisningen egentligen inte två motstridiga saker, utan två olika typer av mål att använda vid olika tillfällen i undervisningsprocessen. Det kan förefalla enkelt att planera undervisningen enkom efter förmågor och sedan i slutet av en läraktivitet ta fram kunskapskraven för att göra en bedömning av eleverna.

Av de svenska lärarnas berättelser kan man tolka det som att de känner en stor press på sig kring bedömning relaterat till betygssättning. De känner att de kontinuerligt ska bedöma eleverna, beskriva för eleverna innan arbetsområdet vad de kommer att bedömas på, göra bedömningen rättssäkert och likvärdigt samt dokumentera sin bedömning under arbetet för att kunna kommunicera den till elever och föräldrar. De uttrycker det som viktigt att bedömningen är omfattande och väldokumenterad för att inte riskera att bli ifrågasatta. Det förefaller därför inte konstigt om denna press positionerar lärarna så att de utgår mer och mer från undervisningsmålen i sin planering av undervisningen. Denna position intas för att helt enkelt klara av att uppfylla alla de förväntningar som en diskurs om pseudo-formativ bedömning och likvärdighet ställer på läraren. Som berörts tidigare finns inte utrymme här att ytterligare fördjupa de olika didaktiska dilemman såsom spänningar kring bedömning som finns i undervisningen. Det är emellertid uppenbart att det finns en 
tydlig relation mellan positioneringar rörande både bedömning och läroplan, och flera av de andra didaktiska dilemmana som visade sig under den reflexiva undervisningen i studien.

Man kan se en relation mellan det didaktiska dilemmat om balansen mellan undervisningens inriktning mot bildningsmål och utbildningsmål och det som Ljunggren (2008) uttrycker som epistemologiprincipen och det offentliga rummets princip. I en undervisning efter epistemologiprincipen ligger fokus på att utveckla elevernas kunskaper och förmågor för framtida ställningstaganden i politiska frågor och hur eleverna resonerar och argumenterar sätts i förgrunden. Tryggvason (2015) menar att det enligt offentliga rummets princip handlar undervisningen om att "här och nu" diskutera politiska frågor och vad eleverna säger ställs i förgrunden och då även frågan i sig.

I Lgr 11 betonas starkt att eleverna ska utveckla förmågor som exempelvis att kritiskt granska information, att föra underbyggda resonemang samt att framföra och bemöta åsikter och argument. Utvecklande av dess förmågor kan ses som en del av skolans övergripande demokratiuppdrag vilket är ett viktigt bildningsmål, men även om en del av skolans kunskapsuppdrag där dessa förmågor finns som utbildningsmål uttryckta i kunskapskraven. Detta är inte på något vis oförenligt, men som läraren positionerar sig närmre utbildningsmålen genom att kunskapskraven styr planeringen av undervisningen kan motsättningar uppstå. Detta kan leda till att undervisningen med utgångspunkt från politiska och kontroversiella samhällsdilemman blir ett medel för läraren att skaffa sig ett bedömningsunderlag, snarare än en strävan mot bildningsmålen.

Mycket fokus riskerar hamna på att eleverna ska visa tecken på aspekter av förmågorna som beskrivs i kunskapskraven, istället för på den politiska frågan. Om det blir en för stor övervikt av epistemologisering av de kontroversiella frågorna, och inte de politiska frågorna i sig hamnar i centrum, kan elevernas politiska intresse och engagemang försvagas (Crick, 2007; Ljunggren, 2008; Tryggvason, 2015). Omvänt kan en extremposition där enkom bildningsmålen 
och svaren på den kontroversiella frågan sätts i fokus innebära att eleven missar träning i viktiga förmågor och att bedömningen av eleverna blir otydlig.

Vilken positionering som är den rätta i dessa didaktiska dilemman måste återigen relateras till vilket syfte man har som lärare med den undervisningssekvens man planerar. Lärarens främsta syfte kan vara att utveckla elevernas förmågor kring kritiskt tänkande för framtida politiska ställningstaganden i linje med epistemologiprincipen. Läraren kan också prioritera att undervisningen främst ska riktas in mot att eleverna ska få möjlighet att ta egen ställning här och nu till ett aktuellt samhällsdilemma. Lärarens syfte med att ta upp samhällsdilemmat kan vidare vara att ge en vardagskoppling till ett specifikt centralt ämnesinnehåll vilket läraren primärt önskar förmedla. En annan möjlighet är att det primära syftet med aktiviteten är att skaffa underlag för en framtida betygssättning. Den mest gynnsamma positioneringen i dessa och andra didaktiska dilemman ser oundvikligen olika ut beroende på vilket som är syftet med undervisningsaktiviteten.

\section{Om läraren ska vara objektiv, neutral eller ta ställning}

Hur läraren positionerar sig i det didaktiska dilemmat angående bildningsmål och utbildningsmål, samt hur läraren balanserar epistemologiprincipen och det offentliga rummets princip mot varandra, har en relation till spänningar i den reflexiva undervisningen rörande i vilken utsträckning läraren ska uttrycka åsikter i klassrummet. Som beskrevs i förra kapitlet skiljde sig de svenska lärarna under temadagarna en del från studiens övriga lärare beträffande deras objektivitet och neutralitet under diskussionerna. Att vara objektiv respektive neutral i en diskussion kan delvis överlappa varandra även om det går att skilja på begreppen i detta sammanhang (Miller-Lane, Denton \& May, 2006). Neutraliteten handlar här om att de svenska lärarna höll inne med sina personliga åsikter under diskussionerna och objektiviteten relaterar till att de svenska lärarna gärna intog en fiktiv roll som elevens meningsmotståndare och då förespråkade en specifik åsikt som var motsatt elevens. Man 
kan beskriva denna positionering som stark neutralitet och svag objektivitet (Tryggvason, 2015) genom att de svenska lärarna inte ville avslöja sin egen ställning men gärna deltog i diskussionen fast då med en fiktiv åsikt. Denna position kan kontrasteras till den som en av de kroatiska lärarna uttryckte där denne delgav eleverna sin egen åsikt och var tydlig med att det var hans egen åsikt. I undervisningen behandlades sedan lärarens åsikt som en åsikt bland andra i diskussionen och den kunde motsägas av eleverna. Denna positionering beskriver Tryggvason som svag neutralitet och stark objektivitet.

\section{Lärarens neutralitet under den svenska temadagen}

Studiens svenska lärare förhöll sig starkt neutrala under temadagens diskussioner som gällde framtida användning av robotar i samhället samt om genteknik och gav inte uttryck för sina personliga åsikter i frågeställningarna.

I: Om vi tänker mer på genteknik och hur man kan använda det, på adoption för homosexuella par där man kan se argument från båda sidorna. Tänker ni då att "nu ska jag hålla mig neutral här eller objektiv och tänker på vilka konsekvenser det kan få om jag inte gör si eller så”?

Annika: Där brukar jag i alla fall att "nu har vi ett moraliskt och etiskt dilemma här som man kan diskutera från olika sätt" och där uttrycker jag inte mina åsikter, det gör jag inte.

Det didaktiska valet att förhålla sig neutral kan förstås som en önskan att inte påverka eleverna, eftersom man som lärare står i en maktrelation till eleverna och kan påverka dem. Under fokusgruppsintervjun där de svenska lärarna reflekterade över sina didaktiska val i förhållande till de övriga lärargrupperna i studien var dock de svenska lärarna tydliga med att de inte alltid höll sig neutrala. Kom diskussionerna in på värderingar som tydligt var i strid med demokrati och skolans värdegrund kunde de ta ställning och visa personliga åsikter.

Man vill ju att de ska vara mer självständiga och fatta egna beslut 
och jag vill ju inte påverka dem att jag röstar på det partiet till exempel. Sedan om det kommer in på lite känsliga grejer blir det svårare och svårare att blir neutral för då vill man ju förmedla något samhället står för i grund och botten (Mikael, Sverige)

De kontroversiella frågorna som man arbetade med under studien handlade om samhällsdilemman där besluten ligger på en sociopolitisk nivå. Den personliga övertygelse i frågan måste därför även relateras till samhällets bästa som helhet vilken ökar utmaningen för läraren ytterligare. Att ta ställning och ha en egen åsikt och att argumentera med personliga åsikter med elever förefaller hur som helst vara något ovanligt och något som ger avtryck hos läraren.

Annika: Jag blev ju ovän med några elever i höstas när vi hade Sex och samlevnad. Det är första gången det hänt ska jag säga, men jag blev jätteupprörd. De tyckte att det var naturligt att mannen skulle bestämma och ha högre lön och allting. Då kunde jag inte lämna det.

I: Så de körde på det och då...kände du att du tog ställning?

Annika: Där kände jag i efterhand att "herregud", jag vet inte riktigt vad jag vräkte ur mig. Men nu är vi vänner. Men där tänkte jag att här gick jag över gränsen.

Potentiella möjligheter och konsekvens av de svenska lärarnas position kring neutralitet

Riskerna med ett klassrum där läraren tar egen ställning är som de svenska lärarna menar att maktrelationen mellan lärare och elev påverkas vilket också beskrivs av Hess (2009). Ljunggren, och Unemar (2010) visar att en hel del svenska elever upplever att de inte riktigt kan uttrycka politiska åsikter, om de strider mot lärarens åsikter. Detta är ett argument för läraren att hålla sig neutral i diskussionerna. Mot dessa argument ställer Hess (2009) att fullständig neutralitet i princip är omöjlig att uppnå. Därför kan det vara bättre att läraren är öppen med sina åsikter, istället för att hålla dem dolda i 
klassrummet. Dessutom blir det en konstig situation i klassrummet där eleven får dubbla signaler genom att den själv ska få möjlighet att ta egen ställning i en kontroversiell fråga och uttrycka denna, samtidigt som läraren håller sig helt neutral och passiv kring samma fråga.

Det verkar vidare som att lärarnas val att hålla sig neutrala inte endast har didaktiska grunder. I diskussionerna beskriver lärarna att dilemmat kring att hålla sig neutral har en relation till förhållandet till elevernas föräldrar och deras syn på skolan och läraren. För att inte riskera att komma på kant med någon förälder kring något kontroversiellt ämne kan detta medföra att läraren på ett överdrivet sätt håller inne med sina åsikter, även om denne egentligen har en stark åsikt i frågan. Man beskriver en utveckling där lärarna förflyttat sig mot en allt mer neutral hållning på grund av tryck utifrån.

Mikael: Jag tror att lärarna i Sverige blir mer och mer neutrala eftersom man har varit en yrkesgrupp som varit i skottgluggen $\mathrm{i}$ media och det kanske blir som när en gammal bildlärare hade skrivit på ett utvecklingssamtal att "du måste arbeta bättre på lektionen för att nå högre" som då fick spott och spe från en förälder. Det skapar nog för mycket neutralitet emellanåt.

I: Då är vi inne på det som vi var inne på exemplet med den heta diskussionen där du kanske var mest oroad att föräldrarna skulle höra av sig.

Annika: Ja det var ju så att när jag gick hem tänkte jag att "Gick jag för långt?" och jag tänkte att där skulle jag kunnat få ett mejl [från föräldrar].

I: Det är intressant för det du är inne på är att vi påverkas mer och mer av föräldrarna. Inte att läraren har en åsikt men att vi inte intar en åsikt.

Annika: Det är ju ryggen fri-dilemmat och det sprider sig i hela samhället vill jag påstå. 
Vidare beskriver lärarna att deras position vad gäller detta neutralitetsdilemma även har en relation till styrdokumenten och diskursen kring hur dessa tolkas. Läroplanen har en tydlig värdegrund som läraren ständigt måste stå upp för under diskussioner kring kontroversiella ämnen i klassrummet. Under fokusgruppsintervjun beskriver studiens svenska lärare att läroplanens skrivningar även kan tolkas som att man som lärare ska hålla sig neutral och inte alltid stå upp för allt. Man menar att man håller sig neutral för att inte riskera uttrycka åsikter som kan upplevas kränkande av någon elev eller andra berörda. Att man som lärare inte ska kränka någon annan, och speciellt inte någon elev är givet, men samtidigt finns en gräns för vad man kan känna sig kränkt för i en diskussion. Det finns inneboende spänningar mellan yttrandefrihet, allas lika värde, religionsfrihet och demokrati, kring vilka läraren behöver navigera när man diskuterar kontroversiella frågor i klassrummet.

Sedan står det ju också i övergripande mål, alltså den andra delen i Lgr 11, att "alla som arbetar i skolan ska aktivt motverka diskriminering, kränkande behandling av individer och grupper och visa respekt" och så vidare. Då blir det som Lgr 11 tillåter dig nästan bara att vara neutral och så vidare i fall som är brännande. Då kan jag inte gå ut och säga att "Det är en mansvärld och det är vi som tar riskerna så det är klart att vi ska ha högre löner", Om jag skulle ha dessa åsikter, då riskerar jag att hamna på kant med elever och värderingsgrunder. (John, Sverige)

Man kan tolka det som att lärarna känner en osäkerhet kring hur man ska hantera spänningen som finns mellan att läraren har ansvar att värna läroplanens grundläggande värden och samtidigt respektera mångfald och pluralism (Runfors, 2003). Intar läraren en alltför objektiv och neutral position, som nästan kan gränsa till ett slags relativism, är risken att man blir tolerant mot även intoleranta åsikter. I ett pluralistiskt klassrum ska förvisso olika åsikter tillåtas och kunna ställas mot varandra och värderas lika. Läraren måste göra en avvägning om huruvida allmänt tyckande ska tillskrivas samma värde som underbyggda fakta i sitt klassrum. Dessutom behöver ibland läraren i stunden avgöra om en åsikt är tyckande eller fakta 
vilket kan vara en utmaning. För de svenska lärarna i studien bestäms inte deras positionering helt av dem själva, utan de själva positioneras även av läroplan och gällande samhällsdiskurs, vilket också påverkar i vilken grad de tar ställning i klassrummet.

Är det saker som är utom allt tvivel att det här ska man tycka så kan nog läraren i större utsträckning visa sina kort på något vis och tycka till. Också om en eller två tycker något annat. "Det är ok att ställa sig med bilen och gasa utanför någon som sitter och tigger vid en affär." Tycker bara två det och det finns en allmän uppfattning om att det är ingenting man gör då kan läraren på något vis slå ner på detta. Men det är som Mikael säger hela tiden en balansgång och lärare är i skottgluggen stup i kvarten. (Simon, Sverige)

\section{Lärarens objektivitet under den svenska temadagen}

Att vara neutral respektive objektiv är närbesläktade begrepp och de går in i varandra på lite oväntade sätt. Är man starkt neutral genom att inte ta egen ställning och samtidigt starkt objektiv genom att belysa alla möjliga alternativ i frågan, kan det förefalla som om båda dessa hållningar förstärker varandra. Med tanke på problematiken med att vara helt neutral kan dock ett försök till neutralitet av en lärare med en stark personlig övertygelse istället försvaga objektiviteten om eleven ser igenom lärarens neutralitet. På samma gång kan en svagt neutral person som är öppen med sina åsikter men ser dessa som åsikter bland andra, förstärka objektiviteten. En lärare med svag objektivitet, genom att den inte ansvarar för att belysa alla olika perspektiv kring frågeställningen, och svag neutralitet genom att ta egen ställning i frågan lever troligtvis inte helt upp till läroplanens skrivningar. Men å andra sidan skulle denna lärare skapa en väldigt autentisk undervisningssituation för sina elever. Det förefaller finnas diskurser som gör att lärarna blir mer neutrala än vad de egentligen vill och behöver vara, men kanske är det istället en autentisk undervisning där läraren visar personliga åsikter som är det som skapar förutsättningar för ett lärande hos eleverna som stannar kvar livet ut. 
I: Men i övrigt, ska man hålla sig neutral eller ta ställning?

Annika: Jag har ju jättesvårt för det [att hålla sig neutral].

I: Men när du säger att det är jättesvårt känner du då att du borde vara neutral?

Annika: Alltså...nä, jag gör inte det om jag ska vara ärlig, men däremot kanske kan jag trots att jag har en åsikt belysa olika vinklar, trots att jag har en åsikt. Jag tycker kanske att mina lärare jag hade en gång i tiden var personliga och därför också personligheter.

Under fokusgruppsintervjun, där de svenska lärarna diskuterade sina egna positioneringar genom att relatera dessa till övriga lärargruppers, visade det sig att vara objektiv kan ha flera dimensioner. När det gällde att presentera de olika kontroversiella frågeställningarna under temadagen, samt under den del av arbetet då fakta- och informationsinhämtning genomfördes, var samtliga lärargrupper starkt objektiva och olika alternativa synsätt på frågorna gavs utrymme. Samtliga lärargrupper valde det som Stradling, Baines och Noctor (1984) kallar en balansstrategi där läraren presenterar olika åsikter i en fråga så övertygande som möjligt. Fördelen med strategin är att eleverna får se frågan från flera synvinklar, men utmaningen för läraren är att belysa alla åsikter på ett välgrundat vis i diskussionerna och en svårighet är hur mer extrema åsikter ska belysas. Ett alternativ för läraren, om den strävar efter stark objektivitet, är strategin som Stradling m.fl. benämner neutral ordförande. Här förmedlar inte läraren perspektiv i frågan under diskussionerna, och uttrycker givetvis inga personliga åsikter, utan fungerar enbart som debattledare. Denna positionering har en tydlig relation till det didaktiska dilemmat kring arbetsformer. Den förutsätter att eleverna har kunnat skaffa sig väl underbyggda åsikter i frågan tidigare.

Det fanns emellertid skillnader i hur läraren agerade i de muntliga diskussionerna och dessa hänger samman med lärarnas positioner- 
ing kring det närliggande didaktiska dilemmat kring att hålla sig neutral eller inte. Läraren deltog i diskussionerna på alla skolor, men det var betydligt vanligare förekommande på flera av de övriga skolorna att läraren öppet visade sin personliga åsikt och argumenterade i sakfrågan utifrån sin övertygelse, en roll som kan beskrivas som uttalat engagemang (Stradling m.fl., 1984). De svenska lärarna intog istället en åsikt i diskussionerna som var den motsatta till den som eleverna presenterade, en strategi som Stradling m.fl. benämner som djävulens advokat. Det blev därmed elevernas åsikter, och hur de argumenterade, som avgjorde hur läraren tog ställning och lärarens objektivitet försvagas därmed.

Potentiella möjligheter och konsekvenser av de svenska lärarnas position kring objektivitet

De svenska lärarna beskriver att det didaktiska valet att gå in i diskussionerna kan ha lite olika bakgrunder. Sammantaget handlar det om att på olika vis hålla igång och utveckla diskussionen och elevernas argumenterande. Det kan vara att balansera upp en diskussion där någon part är dominant eller för att föra in nya perspektiv om endast vissa perspektiv kommit upp i elevernas egna diskussioner. I detta fall för läraren in nya perspektiv i diskussionen och är i sin lärarroll svagare objektiv, men detta kan i gengäld göra att hela diskussionen mer mångfacetterad. Andra argument kan vara att man som lärare vill förlänga en diskussion där elevernas egna diskuterande avstannat för att elevernas diskussion ska förlängas.

Det kan vara så att en elev har en stark uppfattning om någonting och talar väldigt väl om detta och alltså får man ta den här motsatssidan. Eller bara för att man ska ge den här eleven möjlighet att gå vidare i sin argumentation. Eller kanske i rädsla för att det ska stanna av. Eleven ger ett facit - "jaha, det var de det och så går vi vidare" bara för att de andra sitter som musslor och bidrar inte. Då blir det alltid en diskussion. Det här det mångstämmiga klassrummet, jag vill inte säga att det är en chimär, men det uppstår ju inte hela tiden. Det uppstår ju om det är saker som berör dem, som feminism, jämlikhet är väldigt viktigt, men skulle man diskutera något annat som inte berör dem är de inte lika hågade 
att ta del. Då tror jag att vi lärare "oh vad tyst det är, är vi färdiga nu?" och "det är bara den här tjejen och killen som har kommit fram". Jag tror att man ser det som ett arbetsredskap och då vill man att det ska funka och sedan är det skit samma om de säger att nazismen är skitbra. Jag menar de kan komma med något helt...men man vill ju få igång diskussionen. Då vill man ju att någon säger att "varför tycker du det? Jag tycker att nazismen är jättedålig", men det gör inte eleven utan där behöver läraren komma in. Annars riskerar man att det bara blir platt fall. (John, Sverige)

Ser man på den svenska läroplanen är olika förmågor kring kritiskt granskande, resonemang och argumentation ställda i förgrunden och även viktiga förmågor som läraren ska bedöma för betygssättning. Vad gäller själva kunskapsinnehållet i de kontroversiella frågorna som diskuterades under temadagen är emellertid inte allt detta något som ordagrant nämns i det centrala innehållet, även om flera delar berördes. Med utgångspunkt i detta är det inte orimligt att de svenska lärarnas fokus i större grad hamnar på att utveckla elevernas olika diskussions- och argumentationsförmågor, än på själva frågans kunskapsinnehåll. Med denna position är det också förståeligt att läraren intar en roll som elevers meningsmotståndare i diskussionerna, detta för att utveckla deras förmågor, men kanske även för att testa eleverna och få underlag för en betygssättning, i båda fallen med en position nära läroplanens utbildningsmål.

Det går även att se en koppling till epistemologiprincipen, där det $\mathrm{i}$ första hand handlar om att utveckla elevernas generiska förmågor kring kritiskt tänkande och att argumentera och där frågan i sig används som ett medel. Detta till skillnad mot det offentliga rummets princip där själva innehållet i frågorna är det som är viktigt. Det finns alltså en spänning mellan om det är hur eleverna argumenterar och diskuterar eller vad eleverna säger i sina argument, som är det viktigaste. Beroende på vilken princip som läraren prioriterar i samband med aktiviteten varierar positioneringen kring lärarens objektivitet under diskussionerna. Att de svenska lärarnas didaktiska val 
att inta en roll som djävulens advokat och argumentera mot eleverna, trots att de inte personligen tycker så, kan förstås som god intention att utveckla elevernas förmågor beträffande detta. De svenska eleverna i studien hade överlag också goda förmågor gällande detta och visade engagemang under arbetet. Läggs ett alltför stort fokus på att utveckla elevernas förmågor kring att argumentera och diskutera, och dessutom att betygsbedöma dessa, kan själva frågorna och deras innehåll hamna i bakgrunden. Då riskerar elevernas subjektifieringsprocess och emancipation att reduceras till träning och uppvisande av lösryckta delförmågor. Med en lärare som både förhåller sig neutral och objektiv, och inte intar rollen som en fiktiv meningsmotståndare för eleverna under diskussionerna, skulle ett större fokus hamna på den kontroversiella frågan. Samtidigt finns en risk för att en del åsikter inte skulle komma fram tillräckligt och konsensus skulle uppnås, även om inte frågan var helt utredd. Vidare skulle det kunna innebära att en del av eleverna skulle kunna få en alltför dominerande roll under diskussionerna och i vissa fall skulle extrema åsikter få stort utrymme. De elever som redan har utvecklade förmågor kring att argumentera, resonera och diskutera skulle gynnas ytterligare, medan elever som behöver mer träning och stöd av läraren skulle bli lidande.

\section{Om anpassningar vid muntliga diskussioner ska göras eller inte}

För att delta aktivt i dagens och framtidens samhälle gäller det att ha en god kommunikativ förmåga; man behöver kunna kritiskt granska information samt argumentera och framföra sina åsikter muntligt (Jansson, 2009). Vad beträffar muntliga färdigheter har dessa länge haft en tillbakadragen plats inom skolforskning (Gibbons, 2013) och under 1970- och 80-talen var det läsning och skrivning som stod i fokus, både inom akademin och inom skolan (Strömquist, 1992). När denna studies skolor arbetade med den reflexiva undervisningen hade den muntliga kommunikationen en viktig och avgörande roll eftersom eleverna uttryckte åsikter, argumenterade och diskuterade huvudsakligen muntligen. Vad gäller denna färdighet finns en del elever som upplever aktivt deltagande som jobbigt och intar en väldigt passiv roll i diskussionerna, trots att de sitter 
inne med goda argument och egna åsikter och har god resonemangsförmåga. Som jag tidigare beskrivit gäller detta inte elever som på grund av ett funktionshinder eller något annat tillstånd gör att de har svårigheter att uttrycka sig. Det gäller elever som har en muntlig förmåga men ändå intar en tyst roll. I skollagen står att lärarna med olika pedagogiska metoder ska kompensera för elevers svårigheter och läraren kan göra olika former av anpassningar, varav flertalet mest troligt inte innebär ett didaktiskt dilemma. I detta avsnitt ska emellertid två anpassningar beskrivas vilka de svenska lärarna berörde i sina diskussioner. En gäller om läraren ska anpassa för elever som ogärna uttrycker sig muntligt i diskussioner genom att låta dem argumentera och resonera skriftligt, eller på annat sätt, istället för genom deltagande i muntliga diskussioner med övriga elever. Den andra anpassningen handlar om man ska nivågruppera eleverna när de ska arbeta med muntliga diskussioner i grupp. Då de ingående didaktiska dilemmana kring anpassningar i stor utsträckning samverkar med varandra kommer positioneringar, potentiella möjligheter och konsekvenser för detta metadilemma beskrivas integrerat.

\section{Positioneringar kring anpassning av diskussioner}

För de svenska lärarna var det en självklarhet att samtliga elever skulle delta i den reflexiva undervisningen och att denna undervisning var utvecklande och nödvändig för alla. Denna övertygelse var inte lika stark i alla lärargrupper där åsikter uttrycktes kring att denna undervisning inte passade för lågpresterande elever. Samtidigt som studiens svenska lärargrupp inkluderar alla elever i denna undervisningsform fanns en ambivalens kring i vilken grad tysta och talängsliga elever behövde delta muntligt i diskussionerna. De menade att deltagande i diskussioner kring de kontroversiella frågorna är obligatoriskt och viktig för alla elever, men samtidigt fanns också en acceptans kring att en del elever intar en väldigt tillbakadragen roll under själva diskussionerna.

I: Men om man har bedömning som under den här temadagen, är det rätt mot tysta och blyga elever att låta dem argumentera så här? 
John: Jo, det är det. De kan ju inte heller få det krattat. Är de aktiva kan de faktiskt ta del och det finns mycket forskning som säger att iakttagande är också givande. Men det krävs att de är där och inte sitter med mobiler eller sitter i ett annat rum och fylla i blanketter utan de får vara delaktiga. Men man lär ju sig själv och det är ju att man går på diskussioner eller torgmöte utan att man står och viftar med handen utan man deltar ju och ofta tyst och lär sig något. Sedan går man hem och har en tydligare bild av den politikern eller det partiet. Men inte tusan har du deltagit.

Simon: Det som du är inne på är den här bedömningsgrunden det krångliga. Utgå ifrån att de lär sig ändå är ju trevligt, men när du sedan ska bedöma vad de kan och ett av kraven är att de ska prata, då blir det lite svårt om de inte pratar.

Annika: Det är på något sätt ett dilemma. Man får försöka locka dem.

I: Hur kan man det? Ska man bara sätta ihop tysta i en grupp eller svaga elever?

Simon: Jag tror på det med höga och positiva förväntningar. Det kan hända att tar man för givet att folk kan göra saker som de inte tror de kan så kan några. Baksidan är att vi får ett samhälle där man får ett samhälle där det är ok att säga alltid "Nej det här kan inte jag riktigt". Vi diskuterar nu om vi ska ha ett läsprojekt eller inte och det kan hända att jag var lite gammeldags där. Direkt tror jag att några reagerar med att "Några har problem med att läsa och då ska de ha de här hjälpmedlen". Det tycker inte jag och det skulle inte dyka upp i mitt huvud och har du dyslexi och vi ska träna på att läsa får du ändå träna på att läsa. Det har förändrats på kort tid och nu får man lyssna på band. Men man läser ju inte och oavsett diagnos så utsätts man någon gång i samhället för läsning.

Mikael: Det är ju lite farligt för samhället om det syns och hörs 
för credit för allting. Det är ju inte alltid så att det är den som sitter inne med kunskaper. Vi var inne på löner innan och då har det varit så i skolvärlden att vi har haft någon rektor som sagt att man måste synas på pedagogiskt café [stormöte med lärarna på skolan]. Sedan vad du gör i det andra, det är ju bra att man ska synas, jag tror att vi ibland går långt på det viset.

Man beskriver vidare strategier för läraren att använda sig av för att låta de elever som i huvudsak var tysta under diskussionerna ändå få chansen att visa upp sina kunskaper, exempelvis genom att de kan lämna argument skriftligt. Detta didaktiska dilemma har en stark relation till de svenska lärarnas positionering kring den upplevda vikten av att bedöma alla elever på vad de beskriver som ett rättssäkert sätt. De svenska lärarna ser det som problematiskt att tysta elever kan sitta inne med kunskaper som de inte får chansen att visa upp för läraren under de muntliga diskussionerna. Detta menar de också kan göra att lärare inte använder muntliga arbetsformer i den utsträckning som de skulle kunna. Man kan tolka detta som en position där själva förmågan att delta muntligt i diskussionerna inom den reflexiva undervisningen prioriteras mindre än förmågor att samla in relevant information, bygga upp och formulera argument och resonera kring dessa. Det senare kan eleverna även göra i skriftlig form. Den muntliga förmågan beskrivs som en del av personligheten och medfödd. Samtidigt uttrycks vid andra tillfällen under fokusgruppsdiskussionerna även en position där elevers muntliga förmåga inte är en förgivettagen talang som man har eller inte, utan något som eleven kan träna upp.

Didaktiska dilemman kring anpassningar för tysta elever kan alltså ses som att handla om hur läraren positionerar sig kring en tänkt spänning mellan å ena sidan huruvida muntligt deltagande ska ses som en obligatorisk och viktig förmåga att utveckla för alla i denna typ undervisning och å andra sidan huruvida läraren inte anser att utvecklande av denna förmåga är något den prioriterar. Intas den senare positioneringen kan läraren anse att muntligt deltagande $i$ diskussionerna kan ersättas med att berörd elev diskuterar enskilt med läraren eller att eleven tillåts uttrycka sina argument skriftligt. 
Om läraren, medvetet eller omedvetet, ser förmågan att kunna uttrycka sig muntligt i grupp som en medfödd talang som inte direkt kan utvecklas, ligger det nära till hands att låta eleven uttrycka sina åsikter i annan form. Om man betraktar muntlig diskussionsförmåga som något man kan träna upp, precis som andra förmågor, ligger det närmre till hands för läraren att utmana eleverna till att utveckla sina muntliga förmågor på samma sätt som andra förmågor. Strömquist (2008) menar att elevernas muntliga kommunikativa förmågor inte ska betraktas som något medfött, men att utveckla dessa förmågor är inte problemfritt. Det krävs medveten träning och genomtänkta aktiviteter, men får elever bara rätt förutsättningar kan alla lära sig tala offentligt, menar Strömquist. Motsvarande gäller för argumentationsförmågor och Hundal, Levin och Keselman (2014) konstaterar att färdigheter i att argumentera inte är en naturlig biprodukt av mognad och livserfarenhet, utan något som man får genom långvarig träning i olika läraktiviteter.

Utifrån hur den svenska lärargruppen organiserade temadagens undervisning, och hur de beskriver sin övriga undervisning, ges eleverna kontinuerligt tillfällen att använda sina muntliga förmågor i undervisningen, både i gruppdiskussioner och vid andra tillfällen. Detta kan ses som en mer elevcentrerad undervisning, där eleverna får delta i muntliga praktiker. De svenska lärarna beskriver i samband med att de reflekterar över detta att de förvisso ger eleverna tillfälle att använda sina muntliga färdigheter kring att argumentera och resonera, men samtidigt alltför sällan ger eleverna en systematisk och metodisk träning i dessa förmågor. I undervisningsmodellen som skolorna hade som vägledning under arbetet fanns modeller för att arbeta just med en mer metodisk träning av dessa viktiga förmågor och dessa var uppskattade av studiens svenska lärare när de använde sig av dem. Att elever i svenska skolan behöver mer träning vad beträffar att uttrycka sig muntligt på olika vis beskrivs även av Olsson Jers (2010). Det gäller i form av mer tid i klassrummet för att förbereda framträdanden men även i form av stöd för att förbättra sig. 
Det stöd med argumentationsmodeller och liknande som studiens skolor försågs med var inga didaktiska innovationer utan något som var och en av de involverade lärarna egentligen själva skulle kunnat använda sig av i sin ordinarie undervisning. Det förefaller som att alla involverade svenska lärare i Erasmus+ partnerskapet tycker att en mer metodisk undervisning av elevernas förmågor kring argumentation, och muntlig kommunikation kopplad till detta behövs, men samtidigt tar inte någon lärare riktigt ansvar för det. Teknikläraren framhåller att denne hade önskat arbeta mer med diskussioner i linje med en reflexiv undervisning, men menar att eleverna dessvärre inte har tillräckligt utvecklade förmågor i detta och därför väljer han bort det. NO-läraren försöker lägga in många diskussioner i undervisningen, men menar att det är svårt och utmanande och tror att SO-lärarna kan vara bättre på detta arbetssätt. Dessa i sin tur håller med om att diskussioner och argumenterande naturligt finns i deras ämnen, men de menar att SO-lärare delvis saknar den mer strukturerade metodiken som finns i naturvetenskapen. Dessa ämnen skulle därför på bästa sätt kunna ge eleverna metodisk träning av dessa förmågor. Underliggande finns dessutom en förväntan hos övriga lärare att svenskämnet ska ta ansvar för att lära eleverna argumentera och diskutera muntligt. En svensklärare menar emellertid att just att argumentera inte är något som är framskrivet $\mathrm{i}$ svenskämnets kursplan och därför inget som detta ämne ensamt ska ansvara för. I ämnena svenska och svenska som andraspråk ska läraren visserligen bedöma muntlig färdighet, fast denna förmåga är inte riktigt samma förmåga som att argumentera och resonera muntligt i en diskussion. Läser man emellertid kursplaner i NO- eller SOämnen lyfts förmågor kring att diskutera och resonera fram tydligt, samtidigt som det inte specificeras i vilken form eleven ska kommunicera sina kunskaper och förmågor kring detta.

Potentiella möjligheter och konsekvenser av de svenska lärarnas position kring anpassningar av diskussionerna Lärarens positionering i det didaktiska dilemmat beträffande i vilken utsträckning tysta eleverna ska tvingas till muntligt deltagande i diskussionerna är relaterad till hur läraren ser på syftet med läraktiviteten och positioneringar kring spänningar mellan bildningsmål och 
utbildningsmål. Om lärarens primära syfte är att ta reda på elevens faktakunskaper om det aktuella ämnesinnehållet, eller för den delen att generellt visa förmåga att argumentera och resonera, är det säkerligen mer rättvist mot en tystlåten elev att ge möjlighet för denne att uttrycka detta i en annan form och då positionerar sig läraren på ett vis. Genom att skriftspråket ställer högre krav på tydlighet och precision menar Sandström Madsén (2007) att det kan vara en fördel att låta elever skriva då detta kan skapa ännu större medvetenhet om elevens egna tankar. Har läraren emellertid ett mer bildningsorienterat syfte med den aktuella undervisningsaktiviteten och vill att eleverna ska få prova på demokratiska arbetsformer så att de förbereds för att aktivt delta i samhällslivet blir lärarens position mest troligt en annan. Med detta syfte i förgrunden är det givetvis viktigt att alla deltar i diskussionerna, även om deltagande inte med nödvändighet behöver innebära att alla deltagare är fullt muntligt aktiva. Om läraren har som huvudsyfte med aktiviteten att utveckla elevens förmåga att diskutera muntligt i grupp är en trolig positionering att alla elever verkligen måste delta muntligt under lektionen.

Även om man som lärare ser muntlig argumentation och muntligt resonerande som en utvecklingsbar förmåga, och läraren vill utveckla detta i sin undervisning, ställs likväl läraren inför ett didaktiskt dilemma, eftersom en del elever känner oro och rädsla inför muntliga moment. Gren Landell (2014) påpekar att detta kan ha olika orsaker som blyghet, social rädsla, talängslan, ständig oro, provrädsla, ämnesångest, separationsångest, diagnoser, tvångsbeteenden, selektiv mutism, paniksyndrom, depression eller inlärningssvårigheter. Dessutom spelar saker som genusfrågor, kulturella aspekter, familjeförhållanden och klasstillhörighet in. Att som lärare inte utsätta elever med omfattande oro eller andra funktionshinder rörande att uttrycka sig muntligt för situationer där de ska diskutera i grupp är fullt förståeligt och naturligt. Diskussionerna i denna studie gäller heller inte för dessa elever. Ser man på tysta och talängsliga elever som en grupp befinner sig dessa elever i olika positioner längs ett kontinuum, från allvarliga funktionshinder mot lättare form av blyghet eller ängslan för att ta del i en muntlig diskussion. Någon- 
stans på detta kontinuum finns en gräns där ett mildare tvång kopplat till metodisk talträning på sikt kan hjälpa eleven till en god muntlig förmåga (Strömquist, 2008). Man kan tänka sig att en lärarens välriktade omsorg om en elev med oro inför att delta muntligt kan göra att läraren låter eleven slippa delta $\mathrm{i}$ en diskussion med den goda avsikten att inte utsätta eleven för obehag. Samtidigt riskerar denna omsorg att bli missriktad ifall detta blir återkommande lösning, för då riskeras att eleven aldrig ges möjlighet att utveckla de muntligt kommunikativa förmågor som den kommer att behöva $\mathrm{i}$ sitt framtida liv.

Studiens svenska lärare förflyttade sig mellan olika positioneringar kring det didaktiska dilemmat gällande hur tysta elever ska behandlas i samband med muntliga diskussioner och de insåg komplexiteten i dilemmat. Under fokusgruppsintervjuerna gavs ändå uttryck för en position i det didaktiska dilemmat där man inte gärna vill utsätta tysta elever för tvång att uttrycka sig i de muntliga diskussionerna. Att man som empatisk lärare gör ett sådant val i klassrumsundervisningen är heller inte så konstigt med tanke på att en elevs svårigheter att delta i en gemensam diskussion ofta innebär en tystnad. Denna elevs svårighet blir därmed påtaglig på ett helt annat vis än om exempelvis en elev har svårighet att klara att lösa ett algebraiskt uttryck i matematikboken. Att som lärare mer eller mindre tvinga elever att delta muntligt i diskussioner kan innebära att man utsätter elever för obehag som är mer påtagligt för eleven i sin offentlighet, jämfört med obehaget inför ett svårt algebraiskt uttryck. Matematikläraren låter som regel inte sina elever slippa algebran om det är svårt, utan vinnlägger sig om att hitta vägar för att utveckla elevens förmåga att förstå algebra. Det förefaller dock som om lärare omedvetet resonerar lite annorlunda kring kommunikativa förmågor, även om både läroplanen och framtiden kräver dessa förmågor. Den sociala kommunikationens roll för lärande kan inte underskattas och läraren måste skaffa sig strategier och metoder för att utveckla elevernas kommunikativa förmågor som behövs för att delta i diskussioner inom en reflexiv undervisning. Detta relateras 
till didaktiska dilemman kring hur mer metodisk träning i att argumentera och diskutera ska genomföras och fördelas mellan olika ämnen och lärare.

Ett sätt som diskuterades under fokusgrupperna för att anpassa för elever som ogärna tog plats vid de muntliga diskussionerna var nivågruppering utifrån elevernas förmågor i samband med diskussionerna. Studiens svenska lärare berättade om att de använt sig av detta i andra liknande sammanhang och då med framgång. Under temadagen skapade man emellertid medvetet sammansatta heterogena grupper. De svenska lärarna belyste nackdelen med nivågruppering och menade att elever som placeras i en grupp med muntligt svagpresterande riskerar att få en uppfattning att detta är något konstant. Detta kan sedan leda till att eleven undviker att använda sig av och utveckla sin muntliga förmåga. Även om det inte finns något i styrdokumenten som förbjuder nivågruppering förefaller det som om det finns en viss tveksamhet till detta bland de svenska lärarna.

Enligt Mitchell och Ashing (2015) kan kontinuerlig nivågruppering vara gynnsam för högpresterande elever, men inte direkt för övriga elever i klassen. Det finns även andra potentiella risker med att dela in eleverna i nivåer som stigmatisering, sänkta lärarförväntningar, sämre motivation och bristande självkänsla för vissa elever (Skolverket 2009). Samtidigt menar Mitchell och Ashing (2015) att om läraren lyckas anpassa krav och innehåll efter elevernas förmågor, kan en flexibel nivågruppering under kortare perioder faktiskt gynna alla elever. Att anpassa genom nivågruppering är ett generellt didaktiskt dilemma för undervisningen där läroplanens krav på individanpassning ställs mot en grundtanke med den sammanhållna grundskolan. För svagpresterande elever finns som beskrivits potentiella nackdelar, men ser man utifrån elever som är särbegåvade eller högpresterande skulle denna form av anpassning kunna vara gynnsam för dem. Samtidigt kan det få negativ inverkan på övriga elever i klassen om starka elever plockas bort från övriga grupper. Ser man specifikt till muntliga gruppdiskussioner kan frånvaro av elever med väldigt välutvecklade muntliga färdigheter tänkas innebära att det kan skapas utrymme för övriga elever att ta mer plats. Mitchell och 
Ashing menar att genom att ha en kombination av nivågruppering och blandade grupper kan man få en effektiv miljö för lärande $\mathrm{i}$ klassrummet, men det förutsätter att läraren har en klar strategi för när olika sätt att gruppera eleverna används.

Metadilemmat kring anpassning illustrerar att man som lärare inte bara har olika kunskapsförmedlande och utvärderande syften att förhålla sig till. Som lärare har man även omsorgsansvar för sina elever och i detta finns en medmänsklig instinkt att inte utsätta sina elever för obehag i undervisningen. När det gäller att tvinga tysta elever att delta i muntliga diskussioner eller vad gäller nivågruppering kan lärarens olika syften och ansvar krocka med varandra och en prioritering mellan vilket syfte som för stunden är viktigast måste göras.

\section{Summering av studiens andra fas}

Analysen i detta kapitel behandlar hur de svenska lärarna positionerade sig i olika didaktiska dilemman som uppstår som en följd av spänningar i den reflexiva undervisningen. Detta har diskuterats som följande fyra metadilemman:

1. Elevcentrerade eller lärarcentrerade arbetsformer

2. Undervisning mot bildningsmål eller utbildningsmål

3. Om läraren ska vara objektiv, neutral eller ta ställning

4. Om anpassningar vid muntliga diskussioner ska göras eller inte

Positionerna har intagits delvis genom medvetna didaktiska val, men lärarna positioneras även av yttre påverkan, exempelvis av läroplan och bedömningsdiskurser. I klassrumsundervisningens komplexa vardag finns begränsat med utrymme för reflektion i stunden och därför tar lärarna med sig en hel del förgivettagna positioner in i denna förhållandevis nya form av undervisning. Dessa förgivettaganden baseras på erfarenheter från tidigare undervisning med delvis andra prioriterade syften och intentioner än den reflexiva undervisningen. Detta innebär att en del didaktiska val som görs och positioner som intas sker mer eller mindre oreflekterat och omedvetet. 
I ett dilemmatic space har de olika dilemmana relationer till varandra så att en positionering kring ett dilemma kan påverka positionen i ett annat. De positioner som de svenska lärarna intog gäller för den reflexiva undervisning som bedrevs inom studien och skulle man gjort en motsvarande analys av lärarnas ordinarie undervisning skulle lärarna positionerat sig annorlunda. Det visades i samband med fokusgruppsintervjun där de svenska lärarna gjorde förflyttningar och såg olika konsekvenser med olika positioner angående de didaktiska dilemmana. Det är hela tiden viktig för en lärare att utvärdera och reflektera kring sin praktiska kunskap, för att utveckla sig så att man kan göra ännu gynnsammare didaktiska val framöver. När man arbetar med en delvis ny form av undervisning är det ännu viktigare för läraren att ha med sig en medvetenhet kring undervisningens komplexitet och att syfteskonflikter kan uppstå. Detta behövs för att få syn på de spänningar som finns i denna nya form av undervisning och för att kunna göra tillfredsställande didaktiska val i klassrummet.

Undervisningen inom studien med samhällsdilemman handlar om att kunskaper om natur, teknik, samhälle, ekonomi och miljö ska vägas mot varandra och belysas utifrån etiska, politiska och filosofiska perspektiv. Frågorna i sig är dilemman där det inte finns något entydigt och helt tillfredsställande svar. Sett ur detta perspektiv kan intagandet av en neutral hållning som lärare vara ett bekvämt val, inte minst eftersom de ämnesövergripande frågorna innehåller en del kunskapsinnehåll som inte läraren har utbildning inom. För att läraren själv ska kunna bilda sig en åsikt krävs därför att denne sätter sig in i frågan och lär sig nya saker, precis som eleverna förväntades göra. Detta kan ibland vara tidsödande och gör att en överbelastad lärare i så fall behöver prioritera bort någon annan arbetsuppgift. I och med förgivettaganden bland studiens svenska deltagare att det är eleverna som primärt ska söka information själva och att de ska arbeta i mindre grupper, minskar lärarens ansvar som kunskapskälla i klassrummet. Detta innebär i sin tur att läraren inte anser att den behöver vara expertförberedd på varje fråga. Eftersom läraren dessutom ska hålla sig neutral behöver denne inte omfattande kunskaper i detta avseende heller då den inte själv ska ta ställning. 
Studiens svenska lärare upplever att läroplanen sätter förmågor kring att kritiskt granska, argumentera och resonera framför rena påståendekunskaper. Denna tolkning av styrdokumenten har, tillsammans med en stark bedömningsdiskurs, positionerat svenska lärare så att mycket fokus hamnat på kursplanernas kunskapskrav. Detta innebär att undervisningens inriktning mer handlar om att utveckla dessa specifika förmågor hos eleverna än på sakfrågan i sig. En inriktning mot att eleverna ska visa upp de tecken på förmågor som kunskapskraven beskriver gör att även läroplanens bildningsmål hamnar i bakgrunden. Detta är vidare i samklang med en undervisning där eleverna är aktiva deltagare i en praktik där läraren intar en roll som fiktiv meningsmotståndare, med avsikten att ytterligare utveckla dessa förmågor. Med denna position blir hur eleverna argumenterar och diskuterar viktigare än vad det är eleverna säger och själva frågan. Arbetet med att försöka hitta en rimlig ståndpunkt i de kontroversiella frågorna blir ett medel för att utveckla och utvärdera olika förmågor, istället för undervisningens mål i sig.

När alltför stort fokus hamnar på att visa upp tecken på förmågor uttryckta i kunskapskraven och om elevernas kunskaper om samhällsdilemmat i sig är grunda blir utrymmet och möjligheterna för eleverna att ta egen ställning i frågan begränsad. Med ett $i$ huvudsak epistemologiskt perspektiv och ett förgivettagande om att eleverna i stor utsträckning ska arbeta självständigt $\mathrm{i}$ grupper uppstår frågeställningar kring hur man bäst organiserar elevernas gruppdiskussioner. Dessa handlade dels om att elever med olika förutsättningar ska ges chans att utveckla sina förmågor, dels om huruvida tysta eleverna måste visa upp dessa förmågor muntligt. Läggs alltför stort fokus på elevernas förmåga att resonera och diskutera i diskussionerna kan det vara en rimlig anpassning av undervisningen för en tyst elev att den får visa upp förmågan skriftligt istället. Görs detta regelbundet kan det dock innebära att denne elev inte ges möjlighet att utveckla den viktiga färdighet som att uttrycka sig muntligt är. 
I detta kapitel har beskrivningen av de svenska lärarnas positioneringar och resonemang om de olika metadilemmana relaterats till teori. Detta har pekat på att läraren i sitt didaktiska beslutsfattande behöver förhålla sig till flera olika syften. För att göra gynnsamma didaktiska val behöver läraren medvetet göra en prioritering mellan olika syften, och då inte bara till de rent didaktiska syftena kopplade till kvalificering, socialisering och subjektifiering. Som lärare har man dessutom ett omsorgsansvar för sina elever och ett myndighetsuppdrag där man ska undervisa och utvärdera eleverna med utgångspunkt från skolans styrdokument. Dessa uppdrag för med sig andra syften för lärarens verksamhet som man behöver hantera i sin undervisning. 


\section{FAS III - VERKTYG FÖR PRAKTIKEN}

Resultaten från studiens andra fas ledde fram studiens tredje fas vilken riktar sig mot forskningsfråga III. Denna handlar om hur studiens empiri kan ligga till grund för en didaktisk modell för diskussioner mellan lärare kring utmaningar i denna form av undervisning. Ambitionen var att studiens slutsatser om olika didaktiska dilemman som upplevdes inom den reflexiva undervisningen skulle omformuleras till ett stöd för diskussion och reflektion. Därför kom slutsatserna från studiens två tidigare faser kring de fyra metadilemmana att bilda en grund för en didaktisk modell. Denna modell är i form av ett diskussions- och reflektionsverktyg som fungerar som ett stöd för lärare att kollegialt utveckla sin gemensamma procedurkunskap kring en reflexiv undervisning. Verktyget ska även bidra till att utveckla den enskilde lärarens handlingsförmåga. Detta ska ske genom att utöka lärarens repertoar av strategier för att hantera de olika didaktiska dilemmana som en reflexiv undervisningen ställer läraren inför och som läraren måste hantera i undervisningens komplexa vardag.

I samband med analysprocessen av fokusgruppsintervjun med de svenska deltagarna diskuterades lärarnas olika positioneringar samt potentiella konsekvenser av dessa. Lärarna gav även exempel på lärsituationer när de väljer andra positioner än den de valde i samband med den reflexiva undervisningen och resonerade också om positioner som studiens andra lärargrupper intagit. Ur dessa diskussioner växte en konkret idé fram kring hur kunskaperna om positioner i didaktiska dilemman, vilka illustrerades av fyrfältsdiagram, skulle kunna omformuleras för att skapa ett diskussions- och reflektionsverktyg som kan fungera som en didaktisk modell. 
Didaktiska modeller kan introducera lärare till en mer generell didaktisk analys (Ingerman \& Wickman, 2015) och studiens didaktiska modell vill göra detta genom att erbjuda ett verktyg för diskussion och reflektion. Grunden i detta verktyg är de fyrfältsdiagram som kommer att presenteras i detta kapitlet. Inom ramen för mina licentiatstudier fanns inte utrymme för att fullt ut mangla denna didaktiska modell i undervisningspraktiken på så sätt som Ingerman och Wickman beskriver att man gör i ett didaktiskt modellleringsprojekt. Förlaga till fyrfältsdiagrammen användes dock under den avslutande fokusgruppsintervjun med de svenska lärarna under fas II. Man kan därför betrakta modellen som åtminstone delvis omförhandlad av praktiken. Fyrfältsdiagrammen är baserade på empiriska resultat och den didaktiska modellen kan användas som en grund för framtida utvecklingsarbete eller framtida forskning i form av didaktisk modellering.

\section{Syntesprocess under fas III}

Genom att analysera den empiri som fanns i studien om olika didaktiska dilemman och lärares positioneringar i dessa sågs en möjlighet att omforma fyrfältsdiagrammen som använts som diskussionsunderlag under fas II till ett verktyg att använda vid kollegiala diskussioner. I stället för att placera ut flaggor i fyrfältsdiagrammen som representationer för studiens lärargrupper, skapades fyra extrema idealpositioner i hörnen i varje kvadrant. För att illustrera ytterligheterna i de didaktiska dilemmana placerades en ideallärare i vartdera hörnet som fick representera denna position med ett fiktivt uttalande där läraren argumenterar för sina didaktiska val.

Grundidén med en didaktisk modell i form av ett diskussionsverktyg med olika fyrfältsdiagram var att ideallärarnas uttalanden skulle belysa möjliga didaktiska val som dilemmat erbjuder. Med hjälp av kompletterande frågeställningar till fyrfältsdiagrammet ska det sedan leda in på en utredande diskussion kring vad som kan ligga bakom respektive extrema ideallärares intentioner och syften med sina didaktiska val (se figur 10). Verktyget innehåller även ytterligare frågeställningar vilka ämnar leda in diskussionerna på vilka konsekvenser de olika lärarnas val potentiellt kan få, och vidare 
finns kompletterande frågor av mer normativ art kring vad som är önskvärt i de olika didaktiska dilemmana. Oundvikligen leder diskussionen också fram till att varje enskild lärare reflekterar över sina egna didaktiska val och sin egen position rörande dessa didaktiska dilemman i skolvardagen.

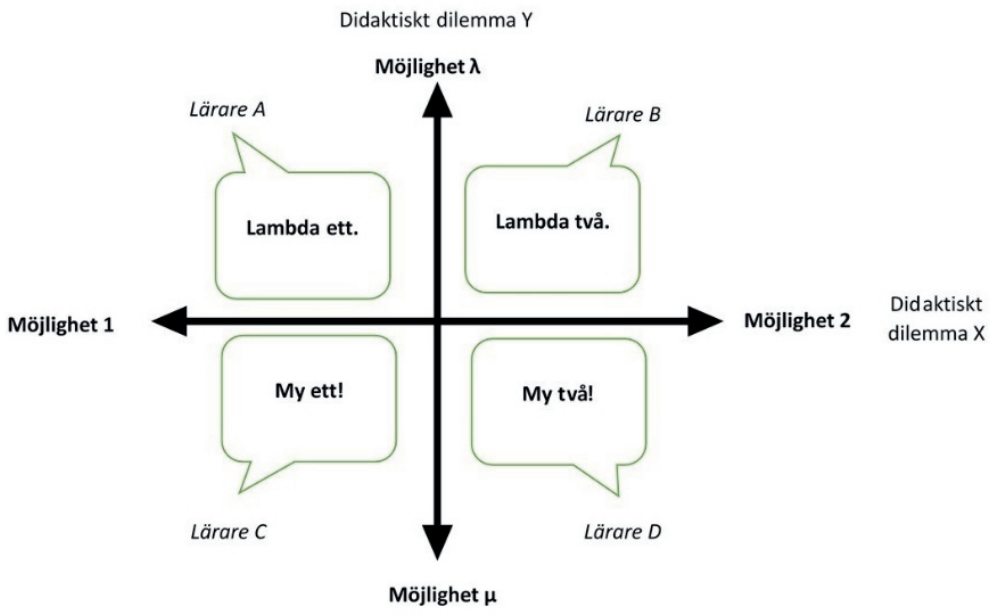

Figur 10. Modell för diskussionsverktyget i fas III.

Fyrfältsdiagrammens nya utformning i fas III som del i ett diskussionsverktyg har en del yttre likheter med värderingsövningen "fyra hörn" och även concept cartoons. Det senare är diskussionsunderlag till elever för att diskutera naturvetenskapliga fenomen som skapades 1995 av Brenda Keogh och Stuart Naylor (1999). En concept cartoon består av en serieteckning med olika barn som uttalar påståenden kring ett naturvetenskapligt fenomen och eleverna ska diskutera dessa uttalanden. När eleverna diskuterar uppstår en kognitiv konflikt där eleven kan ifrågasätta och utforska olika aspekter i den aktuella frågan. Keogh och Naylor skriver att detta underlättas genom att deltagarna kan förhålla sig till färdiga uttalanden, och inte omedelbart behöver uttala sig själv. En studie av lärarstudenter som diskuterade utifrån concept cartoons (Birisci, Metin \& Karakas, 
2010) visar att det fungerar även för vuxna, och tanken i detta kapitel är att en liknande modell även ska fungera för verksamma lärare i diskussioner om didaktiska dilemman. Kollegialt lärande har en stor potential där lärare gemensamt kan utveckla och stödja varandra genom att diskutera sin egen praktik. Samtidigt finns en risk om man ensidigt utgår från egna undervisningserfarenheter genom att lärarna då kan uppleva att man ska döma varandra vilket kan skapa obehag hos deltagare i kollegialt lärande (Langelotz, 2016).

Larsson (1997) menar att lärande ibland för vuxna skiljer sig en del från den traditionella skolundervisningen av elever eftersom vuxna redan har med sig en hel del tankar och tidigare erfarenheter om ämnet. Dessa har redan formats till mönster, och för att ett lärande ska uppstå är det essentiellt att utmana det som är inlärt sedan tidigare och skapa en spänning mellan det gamla och det nya. Larsson ställer upp tre krav på vuxenstudier för att de ska vara meningsfulla. Lärandet måste vara autentiskt och kunna kopplas till lärarens vardagliga erfarenhet av ämnet. Vidare är det viktigt att det som studeras kan sättas in i ett sammanhang för att det ska kännas meningsfullt och slutligen är det avgörande att deltagarna ges utrymme att diskutera genom att bemöta argument och påståenden och då ges även möjligheter att betrakta ämnet från olika perspektiv. Dessa krav är relevanta för studiens praxisorienterade syfte att omforma kunskaper om didaktiska dilemman till ett diskussionsverktyg.

Att arbeta fram ett komplett diskussionsverktyg kring flera dilemman med nödvändig handledningsinformation är ett utvecklingsarbete bortom ramen för denna studie. De empiriskt beskrivna fyra metadilemmana från studiens andra fas omformades till fyra fyrfältsdiagram som motsvarar vart och ett av metadilemmana. Genom en ny abduktiv analys av tidigare resultat i studien byggdes uttalanden upp för att representera de fyra ideallärarnas position rörande dilemmaparen i diskussionsverktyget. Tidigare data gällande det specifika didaktiska dilemmat lästes återigen igenom för få en bild av hur en lärare skulle kunna motivera denna position. Uttalandena som skapades för ideallärarna var inte direkta citat från studiens 
data, men i förekommande fall inspirerade av verkliga uttalanden av deltagarna.

Till diskussionsverktyget skapades en ramstruktur för att sätta in fyrfältsdiagrammet i en större helhet och för att stödja det kollegiala lärandet. Som berörts tidigare ryms emellertid inte utprovning av detta inom ramen för denna studie. Efter fokusgruppsintervjun med de svenska lärarna under fas II förevisades ett utkast till verktyget. Även om dessa fyrfältsdiagram var långt ifrån färdigbearbetade pekade ändå de efterföljande diskussionerna om de fyra ideallärarnas uttalanden på att modellen kan vara ett stöd i kollegiala didaktiksamtal. En grundtanke med verktygets utformning är att det ska vara en flexibel modell där lärare som engagerar sig i kollegialt lärande också själv ska kunna kombinera samman didaktiska dilemman i fyrfältsdiagram. Därför ska de didaktiska dilemman som kombineras samman i de fyrfältsdiagram som presenteras här inte ses som de enda möjliga kombinationerna, utan som ett möjligt underlag att diskutera kring dessa ämnen.

Tanken med diskussionsverktygets utformning var inte att det ska ge deltagarna $\mathrm{i}$ det kollegiala diskussionerna några färdiga svar. Istället syftar verktyget till att hjälpa deltagarna att få syn på olika alternativa positioner som man kan inta kring olika didaktiska dilemman. Med hjälp av verktygets fyrfältsdiagram ska man sedan kunna föra kritiska diskussioner kring relationen mellan de didaktiska positionerna i sin egen praktik och alternativa didaktiska val.

\section{Resultat och diskussion av studiens tredje fas}

Grundtanken med den didaktiska modellen är att diskussionsverktygets fyrfältsdiagram ska kompletteras med en inledande beskrivning kring de didaktiska dilemman som det berör. När man använder detta i ett kollegialt lärande är första steget att titta på fyrfältsdiagrammets fyra läraruttalanden. I och med dilemmans inbyggda karaktär av att inte ha endast en tillfredsställande lösning är det troligt att man kan se för- och nackdelar med alla positioner. 
Till fyrfältsdiagrammet finns vidare frågeställningar i två delar kring dessa didaktiska dilemman för att fördjupa diskussionerna. Tanken med dessa är att det till att börja med ska finnas frågeställningar som är utredande där man diskuterar de fyra ideallärarnas positioner strukturerat. Det handlar om att försöka identifiera vilka intentioner och syften som lärarna haft med sina val. Den andra delen av diskussionsfrågorna handlar om att lyfta de normativa aspekterna av de olika ideallärarnas didaktiska val. Det handlar om vilka implikationer och konsekvenser respektive position kan få för undervisningen och därigenom potentiellt för elevernas lärande och utveckling. Per automatik kommer också lärarna under processen själv att positionera sig i förhållande till dessa ideallärares positioner och kunna få syn på sina egna förgivettagna positioner. Även om det inte finns en enkel kausalitet mellan undervisning och elevers subjektifiering kan verktyget också skapa utrymme för att diskutera hur lärares positioner i olika didaktiska dilemman kan få olika konsekvenser för elevers bildningsprocess som demokratifostran och möjlighet till subjektifiering.

I den didaktiska modellen finns också en efterföljande kommentar utifrån studiens resultat om de didaktiska dilemmana. Denna syftar till att ytterligare stödja det kollegiala lärandet kring de aktuella didaktiska dilemmana och sätta in det i en teoretisk kontext. Med hjälp av kollegiala diskussioner kan lärarnas praktiska kunskap utvecklas kring hur man kan göra bättre didaktiska val i en framtida undervisning. Att undervisa är komplext och lärarens didaktiska val är beroende av en rad olika faktorer som exempelvis klassrumsklimatet, den kontroversiella samhällsfrågan i sig, elevernas ålder och förmågor, de dominerande undervisningsmetoderna på skolan i övrigt, lärarens förkunskaper samt elevernas kunskaper, värderingar och erfarenheter kring frågan (Stradling, 1984). Att använda sig av detta verktyg handlar således inte om att föreskriva en bestämd metod utan istället är idén att belysa olika möjliga didaktiska val, med möjligheter och konsekvenser, för att bredda lärarnas repertoar av handlingsalternativ. 
De olika didaktiska dilemman som kan uppstå i en reflexiv undervisning har som regel relationer till varandra. Därför är en kombination av olika fyrfältsdiagram avgörande för att lärare som arbetar med verktyget ska förstå den komplexitet som finns i den reflexiva undervisningen. Genom att diskutera kring några olika utvalda dilemmapar i sekvens kan deltagarna själva upptäcka relationer och få syn på komplexiteten. Fyra korta uttalanden av ideallärarna kan givetvis inte uttömmande belysa den komplexitet som finns inom undervisningen generellt och den reflexiva undervisningen mer specifikt. Men med kollegiala samtal kring dessa uttalanden, där frågeställningar och fördjupande kommentarer stödjer lärarna att se helheter och relationer, kan förutsättningar skapas för lärarna att själva se relationer mellan de didaktiska dilemmana i fyrfältsdiagram.

Nedan presenteras fyra olika fyrfältsdiagram som vart och ett motsvaras av de fyra metadilemman som beskrevs i förra kapitlet. I avsnitten nedan sammanfattas först studiens empiriska resultat för varje metadilemma, och kunskaper som byggdes upp genom den abduktiva analysen beskrivs. Därefter presenteras och diskuteras fyrfältsdiagrammet som skapats ur det aktuella metadilemmat. Benämningen på fyrfältsdiagrammen och rubrikerna under vilka de presenteras skiljer sig något från hur metadilemmana benämndes i förra kapitlet. De benämningar som används här är de som är tänkta att användas när verktyget testas i praktiken i samband med kollegialt lärande. Ordningen på hur de olika metadilemmanas fyrfältsdiagram presenteras i kapitlet skiljer också sig från tidigare och detta kan givetvis innebära en förvirring för läsaren. Tanken är emellertid att fyrfältsdiagrammen i detta kapitel presenteras i en tänkt ordning för ett kollegialt lärande. Idén är att man går från ett mer konkret och praktiskt metadilemma kring arbetsform till metadilemman som innehåller allt fler teoretiska och filosofiska aspekter. Denna struktur ska öppna upp möjligheter för lärarna att upptäcka relationer mellan de olika didaktiska dilemmana. Med detta sagt är det inte den enda möjliga ordningen att arbeta med fyrfältsdiagrammen. Det finns andra alternativ och givetvis även andra didaktiska dilemman än dessa att diskutera och reflektera över. 


\section{Arbetsform vid faktainhämtning och diskussion}

I analysprocessen under studiens andra fas framträdde ett metadilemma beträffande hur man balanserade en elevcentrerad undervisning mot en mer lärarcentrerad. Två konkreta didaktiska dilemman som belyste denna spänning valdes ut som ett dilemmapar för ett fyrfältsdiagram.

\section{Studiens resultat kring arbetsform vid faktainhämtning och diskussion}

Som beskrivits i förra kapitlet fördes två av de identifierades didaktiska dilemmana samman till ett metadilemma om elevcentrerade och lärarcentrerade arbetsformer som diskuterades när de svenska lärarna jämförde sig med hur de andra skolorna inom studien arbetade. Det ena didaktiska dilemmat gällde i vilket utsträckning som läraren förmedlar relevant fakta och information om det komplexa och kontroversiella samhällsdilemmat eller om läraren mer låter eleverna själva ansvara för att samla in denna information. Det andra didaktiska dilemmat gällde om diskussionerna i huvudsak ska bedrivas i mindre grupper alternativt i helklass.

I kapitlet om studiens andra fas diskuterades resultat från fokusgruppsdiskussioner med de svenska lärarna där de visade en medvetenhet kring deras positions möjligheter och negativa konsekvenser. De menade att deras didaktiska val fick som följd att deras elever fick grunda ämneskunskaper kring samhällsdilemmat och att alla aspekter inte belystes. Detta gjorde i sin tur att det blev svårare för eleverna att fatta välgrundade beslut. Samtidigt pekade de på att eleverna i den arbetsform som gällde under deras temadag utvecklade viktiga förmågor som behövs för att vara en aktiv och ansvarstagande samhällsmedborgare. Motsvarande gällde även hur de svenska lärarna positionerade sig angående de muntliga diskussionerna i den reflexiva undervisningen. Under temadagen på den svenska skolan arbetade och diskuterade eleverna i stor utsträckning i mindre grupper.

Som beskrivits såg de svenska lärarna fördelar med diskussioner i mindre grupper och menade att det mindre antalet elever skulle ge mer talutrymme för eleverna i diskussionerna. Man ansåg även att 
detta skulle innebära att eleverna på ett mer aktivt sätt skulle ta del av en diskussion och beslutandeprocess eftersom de gavs mer eget ansvar. I den komparativa analysen kunde de svenska deltagarna förflytta sig och de visade en medvetenhet kring fördelarna med mer lärarstyrda diskussioner och påtalade att de i andra undervisningssammanhang valde denna strategi.

Om läraren är klassrummets huvudsakliga förmedlare av information och olika synsätt om den aktuella kontroversiella frågan finns goda förutsättningar för att eleverna får en allsidig översikt av frågan. Lämnas eleverna alltför ensamma med kunskapsinhämtningen finns det risk att en del åsikter förbises och att efterföljande diskussioner blir grunda och onyanserade. När läraren är huvudsaklig kunskapsförmedlare går eleverna miste om träning i att själva söka och granska information, vilket i sig är viktiga förmågor för eleverna att utveckla. När eleverna själva får vara aktiva som kunskapsproducenter i denna del av beslutsfattandeprocessen blir lärandet autentiskt och därmed mer intressant för eleven.

I en undervisning i enlighet med lärarcentrerade arbetsmetoder ligger det nära till hands att undervisningen primärt bedrivs i helklass med läraren i centrum. När det gäller diskussioner kring samhällsdilemman kan det vara fördelar med detta jämfört med att låta eleverna diskutera mer på egen hand i mindre grupper. En aspekt är att med läraren som samtalsledare kan denne säkerställa att alla elever och alla åsikter verkligen kommer upp i diskussionen. Läraren har här möjlighet att styra diskussionen om den antingen hamnar i extrema åsikter, blir överhettad eller är på väg mot konsensus. Fördelen med att dela upp eleverna i mindre grupper är å andra sidan att fler elever blir aktivt deltagande i diskussionerna när talutrymmet för varje individ ökar. Får alla elever en chans att uttrycka sig och testa sina åsikter kan det skapa förutsättningar för större elevengagemang. Gruppens litenhet innebär dessutom gynnsammare förutsättningar för tystare och mer tillbakadragna elever att kunna delta aktivt. Samtidigt finns utmaningar kring gruppdynamik och ansvarstagande när inte gruppen har en lärare ständigt närvarande. 


\section{Fyrfältsdiagram om arbetsformer}

För att belysa dessa didaktiska dilemman och aspekter på möjliga positioner lärare kan inta sammanställdes ett fyrfältsdiagram enligt figur 11. På den vågräta axeln markeras att eleverna själva är de som samlar in relevant fakta och information kring den aktuella frågan respektive att det är läraren som är den primära förmedlaren av detta i klassrummet. Lärare A och Lärare C förespråkar det förra alternativet med lite olika argument medan de två övriga lärarna argumenterar för läraren som faktaförmedlare. På den lodräta axeln illustreras dilemmat mellan att hålla diskussioner i helklass eller i mindre grupper och lärare A och lärare B beskriver fördelarna med helklassalternativet med lite olika argument. De fyra uttalandena som beskrivs kan omöjligen ta upp alla aspekter kring dessa didaktiska dilemman, men de kan vara en utgångspunkt för en diskussion. Troligtvis är det svårt att själv positionera sig på samma ställe som en av de fyra ideallärarna utan man kan se både för- och nackdelar med alla positioner och alla argument, vilket också är ett av de inneboende kännetecknen med didaktiska dilemman.

Lärare A ser förmågan att söka och granska information som viktig och låter därför eleverna ta stort ansvar för faktainhämtningen, men i diskussionerna föredrar läraren att arbeta i helklass för att kunna kontrollera diskussionerna och säkerställa att olika åsikter och perspektiv kommer alla till del. Även Lärare B diskuterar i helklass med liknande motiv men poängterar även att denna arbetsform kan hindra att extrema åsikter får fritt spelrum. Lärare B är den som ansvarar för att förmedla relevant information till eleverna angående frågan med motiveringen att frågorna är för komplexa för eleverna att hantera på egen hand. Även Lärare D är den primära faktaförmedlaren och gör det för att se till att alla elever får en vidd i de olika aspekter och perspektiv som frågan innehåller. Denne lärare föredrar emellertid gruppdiskussioner så att fler elever ska få talutrymme. Även för Lärare C är gruppdiskussioner den huvudsakliga arbetsformen och betonar att detta gör att fler elever vågar ta plats i diskussionerna och att eleverna i gruppen kan lära av varandra. Lärare $\mathrm{C}$ har vidare inställningen att den inte vill vara den primära 
faktaförmedlaren utan elevernas egna sökande efter fakta är en viktig del i processen att bilda sig en egen åsikt.

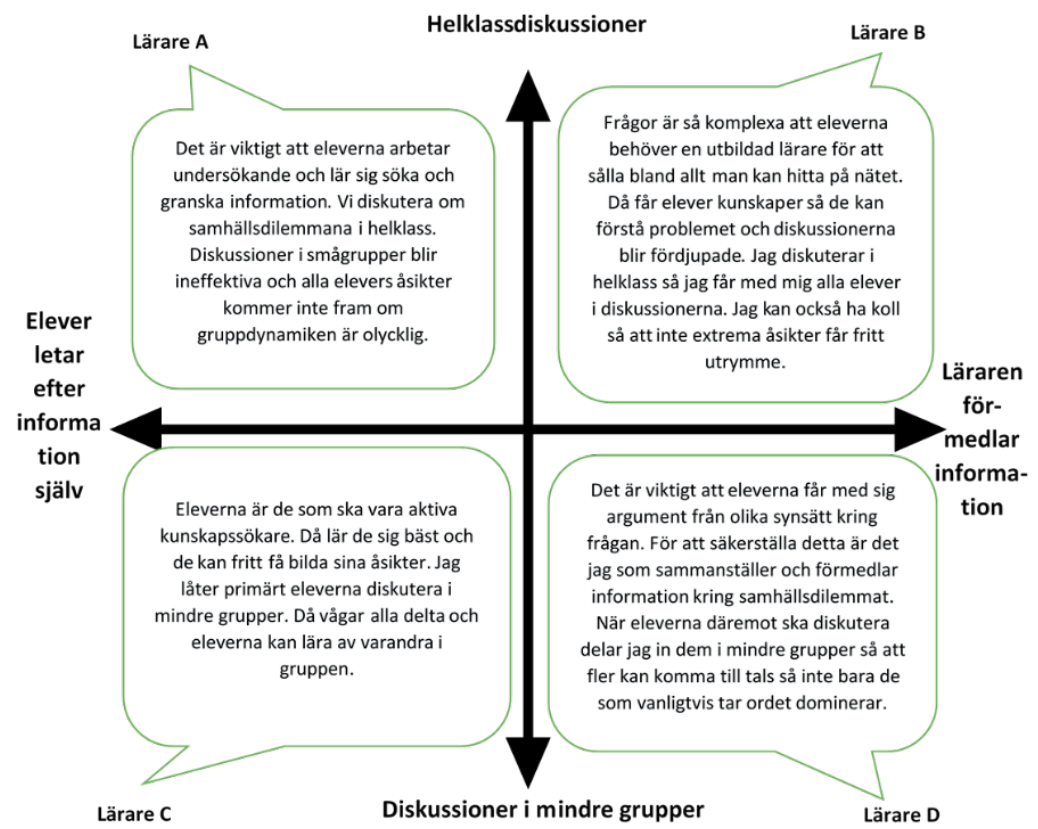

Figur 11. Fyrfältsdiagram till diskussionsverktyget kring arbetsform och informationsinhämtning.

\section{Diskussion kring fyrfältsdiagrammet om arbetsformer}

Fyrfältsdiagrammet om lärarens val av arbetsform kan kopplas till skolans kvalificeringsfunktion. Biesta (2009) menar att skolan har ett viktigt syfte att förse eleverna med kunskaper och färdigheter som de behöver för framtiden. Inom kvalificeringen i den reflexiva undervisningen handlar det om att förbereda eleverna så att de kan delta i beslutsfattande om politiska lösningar på samhällsdilemman. Eleverna behöver förberedas genom att få kunskaper om samhällsdilemmat i sig för att de ska kunna ta egen ställning, men samtidigt också utveckla olika förmågor som kan sammanfattas som kritiskt tänkande. 
Det optimala är att eleverna får gedigna kunskaper om det aktuella samhällsdilemmat i sig, ges utrymme för att även utveckla förmågor som argumentation, reflektion och kritiskt tänkande samt får andra metaperspektiv på samhällsdilemmat (Simonneaux, 2014b; Sjöström \& Eilks, 2018). Hur man konkret ska balansera dessa olika delar mot varandra, speciellt i en tidspressad undervisningssekvens är något som är svårare för teorin att beskriva. I en mer elevcentrerad undervisning som Lärare $C$ väljer ges eleverna tid att träna förmågor som att söka och utvärdera information och att diskutera och argumentera. En mer lärarcentrerad och sammanhållen undervisning i linje med Lärare B:s position har emellertid även den sina fördelar, exempelvis genom att läraren enklare kan se till så att alla elever får del av relevant information kring samhällsdilemmat.

För att elever genom den reflexiva undervisningen ska utvecklas till självständiga och ansvarstagande individer som deltar i samhällets utveckling och förändring behöver eleverna ha såväl kunskaper om samhällsdilemman som utvecklade förmågor kring kritiskt tänkande. Utbildningens subjektifieringsfunktion (Biesta, 2015) är sammankopplad med kvalificeringen av eleverna genom att alla utbildningens funktioner både är förutsättningar för varandra och går in i varandra. Biesta skriver att olika syften ibland kan stå i konflikt med varandra och som lärare måste man hitta en balans mellan olika syften och att göra avvägningar och prioriteringar. Att alltid befinna sig i en position i fyrfältsdiagrammet innebär att eleverna får begränsade möjligheter att arbeta mot alla syften i den reflexiva undervisningen. Det är emellertid inte lika säkert att man som lärare tvunget ska förflytta sig mellan alla olika positioner under en och samma undervisningssekvens. Biesta skriver att lärare gör didaktiska val, både i planeringen av och i genomförandet av undervisning, utifrån det eller de syften man prioriterat för den aktuella undervisningsperioden.

Subjektifiering i den reflexiva undervisningen handlar om att eleven ska ges utrymme att ta egen ställning baserat på kunskaper om olika perspektiv på ett samhällsdilemma. I undervisningspraktiken kan lä- 
raren lägga emfas på olika saker. Väljer läraren att lägga tyngdpunkten på "ta egen ställning" kan en viss position vara motiverad. Läggs tyngdpunkten på "baserat på kunskaper om olika perspektiv" hamnar man i en annan position. Man kan ställa sig frågan om det verkligen är möjligt för eleverna att fullt ut ta ställning i en fråga om de inte givits möjlighet att få relevant information kring samhällsdilemmat. När det blir en alltför stor övervikt mot elevaktiv träning av förmågor riskerar elevernas kunskaper om det aktuella samhällsdilemmat bli grunda. Diskuteras det dessutom primärt i smågrupper riskerar det bli allmänt tyckande, snarare än resonemang baserat på olika intressenters perspektiv och värderingar. Med denna utgångspunkt får kunskapsbasen en överordnad betydelse vilket innebär att läraren bör ta en större roll vid informationsinhämtning och diskussion, för att det ska skapas utrymme för subjektifiering.

Man kan å andra sidan ställa sig frågan hur mycket information och kunskaper man egentligen behöver ha för att kunna ta en välgrundad ställning i ett samhällsdilemma. Tar läraren en större roll och genomför en alldeles utmärkt undervisning är det ändå kanske inte rimligt att begära att en genomsnittselev på högstadiet ska kunna överblicka alla aspekter av en komplex kontroversiell fråga. Ser man saken på detta viset kan man hävda att det är underordnat att eleven fått möjlighet att basera sitt ställningstagande på kunskaper om alla olika perspektiv på ett samhällsdilemma. Det överordnade blir ur denna synvinkel att eleven får ta ställning, om än utifrån lite grunda kunskaper. Eleven behöver givetvis basera sitt ställningstagande på några olika aspekter som finns kring samhällsdilemmat, men eleven behöver kanske inte nödvändigtvis ha kännedom om alla väsentliga aspekter. Det kanske räcker med de aspekter som eleven själv hittat. Har eleven aktivt samlat in och utvärderat information kring frågan på egen hand har den fått en autentisk upplevelse av beslutsfattande och ställningstagande. En elev i en mer lärarcentrerad undervisning har förmodligen djupare kunskaper om samhällsdilemmat. Men om inte informationen upplevs som elevens egen riskerar detta begränsa elevens utrymme att ta en egen ställning. 
Lärare strävar säkert efter en undervisning där eleverna själva aktivt får söka och utvärdera information, men även får ta del av lärarens kunskaper i ämnet. Eleverna ska utveckla förmågor kring kritiskt tänkande samtidigt som läraren aktivt hjälper eleverna att få del av alla relevanta aspekter av samhällsdilemmat. Klassrumsvardagen är dessvärre inte alltid så optimerad att det blir så eftersom lärare påverkas gällande dessa dilemman av andra faktorer. De svenska lärarna beskrev en diskurs grundad i eget arbete-traditioner och IKTsatsningar som skapade ett förgivettagande om fokus på elevaktiva arbetsmetoder i denna undervisningsform. Andra lärargrupper beskrev att traditioner och innehållstyngda kursplaner positionerade dem mot en mer lärarcentrerad och ämneskunskapsförmedlande undervisning.

\section{Lärarens ställningstagande i diskussioner}

Ett annat metadilemma i andra fasen av studien diskuterade dilemman angående om läraren ska ta ställning i samband med diskussioner kring kontroversiella samhällsfrågor. Ställningstagandet kan vara ett personligt ställningstagande där man delar med sig av sina egna åsikter eller ett professionellt ställningstagande. Det senare kan bestå i att man antingen aktivt tar ställning för något i värdegrunden eller vara ett ställningstagande som är didaktiskt motiverat. Att som lärare visa en ståndpunkt kan emellertid också medföra konsekvenser i klassrummet.

\section{Studiens resultat kring lärarens ställningstagande i diskussioner}

De två delvis tangerande begreppen objektivitet och neutralitet diskuterades i förra kapitlet i termer av stark respektive svag. Vad gäller objektivitet kan man vara objektiv i olika delar av den reflexiva undervisningen, men i detta fallet gäller det lärarens objektivitet i samband med konkreta klassrumsdiskussioner kring samhällsdilemmana. Vad gäller neutralitet handlar det om i vilken utsträckning läraren delar med sig av sina personliga åsikter om dessa frågor.

Det har visats tidigare i uppsatsen att de svenska lärarna var starkt neutrala i diskussionerna under temadagen och i fokusgruppsdis- 
kussionerna uttrycktes det som att detta var en förgivettagen hållning hos lärarna. Lärarna motiverade detta med att de inte ville påverka elevernas ställningstagande, inte hamna i konflikt med föräldrar samt att läroplanen begränsade deras yttrandefrihet. Studiens övriga lärargrupper var inte lika starkt neutrala som de svenska lärarna. Denna mer partiska position skapade förutsättningar för en mer autentisk diskussion och även möjlighet för läraren att socialisera eleverna. Samtidigt kan ett personligt ställningstagande av läraren begränsa elevernas möjlighet att uttrycka egna ställningstaganden.

Neutralitet och objektivitet överlappar varandra och de utländska lärarnas större öppenhet med sina egna åsikter kan bidra till en starkare objektivitet. Detta under förutsättning att läraren ser sin egen uppfattning som en av flera giltiga åsikter och även presenterar dessa åsikter i diskussionen. De svenska lärarna var svagt objektiva i diskussionerna med eleverna genom att de gärna intog motsatt åsikt till eleverna. Denna roll som djävulens advokat motiverade lärarna med att de ville hålla igång en diskussion som nått konsensus samt att de ville utmana elevernas ställningstaganden och åsikter. Genom att läraren intar en svagare objektivitet och argumenterade emot menade de svenska lärarna att diskussionen kunde fortsätta längre. Detta innebär att eleverna utmanas att vässa och förbättra sina argument och i denna process utvecklar eleverna sina förmågor. En fara med denna strategi är att själva samhällsfrågan hamnar i skymundan, till förmån för metodisk förmågeträning. Denna undervisningsstrategi kan innebära att utrymmet för eleven att ta egen ställning kring frågan kan begränsas. Detta eftersom fokus inte ligger på vad eleverna argumenterar utifrån utan på hur de argumenterar. Frågan i sig riskerar då att endast bli ett medel för att utveckla förmågor.

Som diskuterats tidigare är de didaktiska dilemmana kring lärarens objektivitet och neutralitet sammanlänkade och en positionering kring det ena påverkar det andra på flera sätt. Detta innebär att positionerna i ett fyrfältsdiagram kan vara mer komplicerade än vad de först kan verka. Är läraren svagt neutral och visar sin egen åsikt gör det att objektiviteten hos läraren stärks, i och med att läraren är 
öppen med sina ståndpunkter. Detta förutsätter att klassrumsklimatet tillåter andra argument än lärarens. Om eleverna påverkas av lärarens ställningstagande finns risk att inte alla argument lyfts upp av eleverna. När läraren intar en svag objektivitet och är djävulens advokat kan det innebära att mångfalden av argument i diskussionen ökar om läraren lyfter fram åsikter och synpunkter som inte fått något utrymme. När läraren intar fiktiva ståndpunkter kan det dessutom innebära att den inte behöver riskera att påverka eleverna med sina personliga åsikter. Detta är emellertid under förutsättning att eleverna kan läsa av läraren och förstå att den intar en roll för att provocera och utmana eleverna. Gör inte eleverna detta kan denna roll som djävulens advokat påverka både elevernas möjligheter att inta egna åsikter och deras integritet.

Om läraren håller sig både svagt objektiv och svagt neutral kommer diskussionerna främst att röra sig kring de åsikter eleverna för med sig in i klassrummet samt lärarens personliga åsikter. Är det liten variation bland dessa föreligger en risk att eleverna inte får möjlighet att se alla de dimensioner som frågan innehåller vilket kan begränsa deras möjlighet att bygga upp underbyggda åsikter i frågan. Däremot blir diskussionen i detta klassrum med största sannolikhet väldigt autentisk och en upplevelse för eleverna kring hur många diskussioner kring kontroversiella frågor tar sig uttryck i livet utanför skolans väggar.

\section{Fyrfältsdiagram om ställningstagande}

Tidigare i uppsatsen har lärarens ställningstagande diskuterats i de teoretiska termerna av olika styrkor av neutralitet och objektivitet efter Tryggvason (2015). Då dessa begrepp i sig kan ha flera betydelser och delvis överlappar varandra har andra benämningar valts på fyrfältsdiagrammet. De nya benämningarna är mer konkreta för att de ska vara mer lättillgängliga för de lärare i praktiken som den didaktiska modellen är ämnad för. En konsekvens kan bli att en del nyanser i ursprungsbegreppen försvagas. Fyrfältsdiagram som presenteras här ska emellertid inte belysa samtliga didaktiska dilemman som kan uppstå i en reflexiv undervisning. Det finns även utrymme 
för andra fyrfältsdiagram som belyser alternativa nyanser av objektivitet och neutralitet.

I fyrfältsdiagrammet i figur 12 illustreras på den vågräta axeln i vilken utsträckning läraren delar med sig av sina egna åsikter i diskussionerna. Neutral innebär att läraren inte berättar sina personliga åsikter, medan en position i den motsatta änden innebär att läraren inte har några tveksamheter kring att uttrycka sina egna ställningstaganden i diskussioner kring samhälldilemmana. Lärare E och lärare $G$ uttrycker sina egna åsikter i diskussionerna, medan lärare $F$ och lärare $\mathrm{H}$ håller inne med sina. På den lodräta axeln beskrivs det didaktiska dilemmat gällande om läraren ska hålla sig alltigenom objektiv i diskussionerna kring samhällsdilemmana och inte lyfta fram något perspektiv mer än ett annat. Detta beskrivs i fyrfältsdiagrammet som perspektivorienterande och då belyser läraren alla relevanta perspektiv på ett likvärdigt sätt. Detta ställs mot att en lärare kan vara partisk i diskussionerna och då medvetet belysa en del perspektiv mer än andra. Vad gäller objektivitet är Lärare E och lärare F perspektivorienterande medan de två övriga inte håller så hårt på objektiviteten i diskussionerna, utan väljer att belysa en del perspektiv mer än andra.

Lärare E tar visserligen egen ställning men strävar efter ett klassrum där lärarens åsikt betraktas som en bland andras och kan ifrågasättas. Läraren lyfter även upp andra argument och kan ses som perspektivorienterande, åtminstone om eleverna vågar ifrågasätta läraren. Lärare G tar också egen ställning och strävar efter en autentisk undervisning och vill att diskussionerna ska utgå från elevernas perspektiv. Lärare $\mathrm{G}$ deltar gärna med sin egen åsikt i diskussionerna och blir därigenom partisk. Lärare $\mathrm{H}$ väljer en annan slags partisk roll och argumenterar emot eleverna med fiktiva ställningstaganden som en djävulens advokat. Detta gör den för att den vill utveckla elevernas argumentationsförmågor och deras kritiska tänkande. För Lärare $F$ är valet att hålla sig neutral vilket kan vara grundat $i$ att den inte vill påverka eleverna eller hamna i konflikt med någon på 
grund av på sina personliga åsikter. Lärare $\mathrm{F}$ är perspektivorienterande och intar en roll som en moderator som lyfter fram alla olika aspekter och synsätt rörande den aktuella frågan.

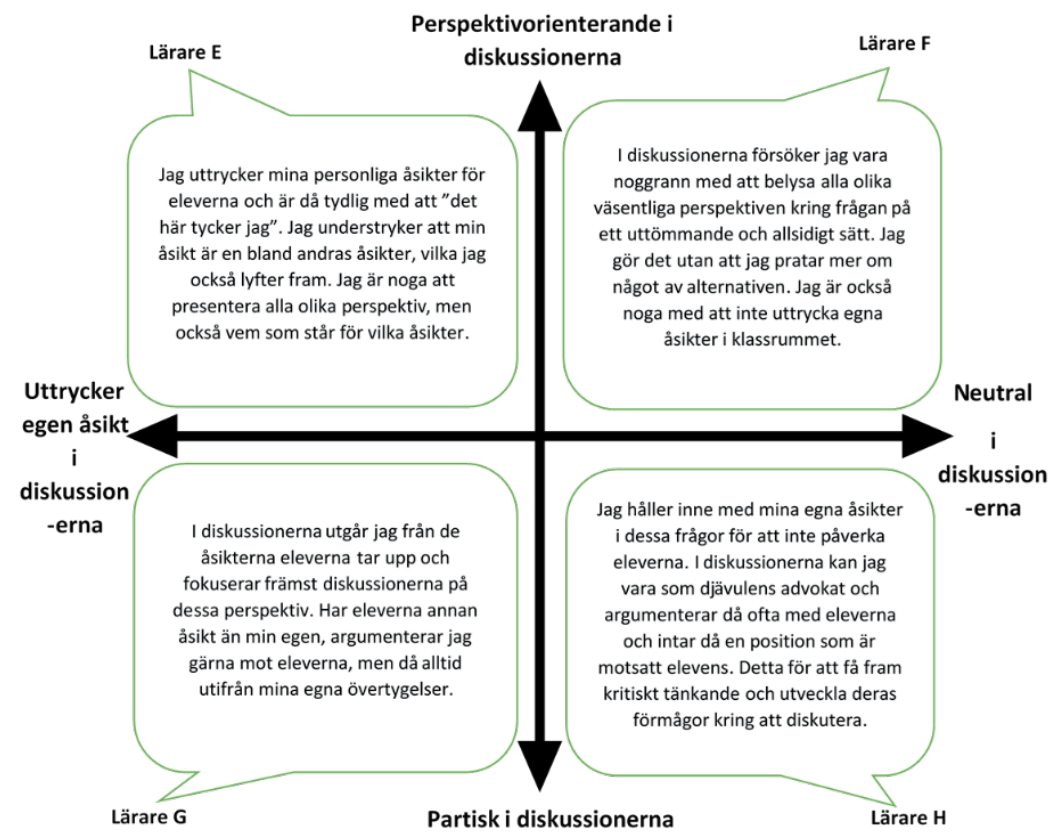

Figur 12. Fyrfältsdiagram till diskussionsverktyget kring i vilken utsträckning läraren ska ta ställning i diskussioner i den reflexiva undervisningen.

\section{Diskussion kring fyrfältsdiagrammet om ställningstagande}

Hur man som lärare positionerar sig i det didaktiska dilemmat på den lodräta axeln i diagrammet kan kopplas till kvalificering respektive subjektifiering (Biesta, 2009) samt till epistemologiprincipen respektive det offentliga rummets princip (Ljunggren, 2008). I Lärare $\mathrm{N}$ :s undervisning hamnar själva samhälldilemmat i bakgrunden och det primära syftet är att förbereda eleverna för ett framtida politiskt deltagande genom att utveckla generella politiska kunskaper. Detta beskriver Ljunggren som undervisning efter epistemologiprincipen och är en kvalificering för framtida subjektifiering. 
En partisk position där läraren intar en roll som djävulens advokat (Stradling m.fl., 1984) kan göra att eleverna utmanas av läraren i diskussionerna. Denna position som partisk kan kopplas till en elevcentrerad position i fyrfältsdiagrammet om arbetsformer. Det blir en undervisning efter epistemologiprincipen där fokus lätt hamnar på att utveckla olika förmågor med huvudsyftet att förbereda eleverna att ta ställning i framtiden. När läraren har en mindre roll i informationssökning och diskussioner och tar en partisk och svagt objektiv roll genom att ha motsatt åsikt till elevernas ligger det nära till hands att läraren även är neutral och håller inne med sina egna åsikter. Att läraren väljer att inte exponera sina personliga åsikter kan ha olika orsaker. Det kan bero på att den inte vill påverka elever i deras beslutsfattande och lägga fokus på elevernas ställningstagande eller att undvika att stöta sig med föräldrar eller andra i närsamhället (Milller-Lane, Denton \& May, 2006; Hess, 2009).

Om läraren är perspektivorienterande i diskussionerna genom att lyfta fram flera olika perspektiv på samhällsdilemmat kan detta bidra till att eleverna ges utrymme att ta egen ställning. Ljunggren (2008) beskriver undervisning där eleverna ges utrymme att ta egen ställning i samhällsdilemmat "här och nu" som det offentliga rummets princip. Som behandlats tidigare menar Ljunggren att man ska se dessa principer som komplement till varandra. Läraren bör välja strategi efter de mål och syften man har för den aktuella undervisningen, vilket kan relateras till diskussionen kring förra fyrfältsdiagrammet.

Fyrfältsdiagrammet belyser även i vilken utsträckning läraren skaffar sig möjlighet att arbeta mot utbildningens socialiseringssyfte. Intar man en neutral roll i diskussionerna begränsar läraren sin möjlighet att vara normativ i undervisningen. Biesta (2009) menar att utbildningen har en socialiseringsfunktion och ska överföra värderingar, traditioner, färdigheter och kunskaper till eleverna så att de kan fungera i samhällets rådande sociala, politiska och kulturella ordningar. Enligt läroplanen ska läraren uppfostra demokratiska medborgare och skolan har ett tydligt normativt uppdrag. Skolan 
har samtligt ett kritisk-reflexivt bildningsuppdrag att utveckla elever som kan och vågar ifrågasätta gällande normer, värden och sociala ordningar (Sjöström, 2013; Sjöström \& Eilks, 2018). Dessa båda uppdrag blottar den syfteskomplexitet som finns i en multimotivdriven verksamhet som skolans (Alnervik, 2013; Frelin, 2013).

Billig (1988) pekar på att denna spänning mellan en lärarcentrerad undervisning med en förmedlande lärarroll och en elevorienterad undervisning med en opartisk och neutral lärare kan härledas till ett övergripande ideologiskt dilemma mellan att bevara och ifrågasätta de rådande samhällsordningarna. Väljer läraren en partisk positionering finns möjlighet för läraren att vara normativ och betona samhällets gällande ordningar och värdesystem. Detta beror dock på av vilka orsaker som läraren intar positionen. I studien beskrev de italienska lärarna att de gärna intog en partisk och normerande roll i diskussionerna och de gjorde det just med syfte att socialisera eleverna. Den svenska läraren motiverade sin partiska position med att det var en metod för att utveckla elevernas resonemang och deras argumentationsförmåga. Då försvagas lärarens möjligheter att vara normativ och socialiserande $\mathrm{i}$ och med att läraren primärt väljer ställningstagande så att det ska vara motsatt till elevens.

Läraren som väljer en perspektivorienterande position förhåller sig mer objektiv. Väljer läraren en perspektivorienterande roll finns även utrymme att vara normerande då den ändå måste göra ett urval av perspektiv och välja bort en del. Läraren behöver balansera en normförmedlande roll mot möjligheterna att skapa utrymme för pluralistiska diskussioner i klassrummet (Amnå m.fl., 2010). Det är en utmaning där man behöver ta hänsyn till i vilken grad man ska ta med åsikter som bedöms som externa enligt rådande synsätt och hur man ska väga evidensbaserad kunskap mot andra typer av argument.

Utbildningens subjektifieringsfunktion och socialiseringsfunktion ser Biesta (2009) som två motsatser som samtidigt är förutsättningar för varandra. Skolan ska ge alla elever en gemensam grund av normer och värden och i den reflexiva undervisningen skapar denna 
grund även något för eleverna att subjektifieras gentemot. Om den reflexiva undervisningen får en alltför stor normativ inriktning och läraren inte ger utrymme för elever att ifrågasätta den rådande ordningen begränsas emellertid möjligheterna för elevernas egna ställningstaganden.

\section{Anpassning av diskussioner}

I den reflexiva undervisningen har muntliga diskussioner en stor plats och nyttan för eleverna i deras framtida liv att ha utvecklade förmågor att muntligen kommunicera och argumentera kan inte nog underskattas. Samtidigt fanns det en del elever som ogärna tog plats vid de muntliga diskussionerna under temadagarna. Utmaningarna kring hur man ska hantera dessa tysta elever diskuterades även i fokusgrupperna. Som tidigare beskrivits gäller det inte elever som på grund av funktionsnedsättning eller funktionshinder inte pratar, utan elever som kan kommunicera och argumentera muntligt, men helst väljer att göra det i liten omfattning i dessa situationer.

\section{Studiens resultat kring anpassning av diskussioner}

Ett didaktiskt dilemma som analysen under fas II visade på var i vilken utsträckning läraren ska kräva att dessa tysta elever ska argumentera, resonera och bemöta åsikter muntligt under diskussionerna i den reflexiva undervisningen. En position är att man ska se muntligt deltagande som obligatoriskt och på något vis tvinga eleverna att uttrycka sig om eleverna vill att läraren ska ta del av deras kunskaper och åsikter i den aktuella frågan. En position som kan sättas emot denna är att läraren gör en anpassning och istället låter eleven visa prov på sina argument och sina resonemang skriftligen. Oavsett position är det rimligt att eleverna erbjuds en mer metodisk träning av förmågorna att muntligt diskutera, argumentera och resonera, även om det på skolorna inom denna studie föreföll vara något som till stor del saknades. Om läraren gör en anpassning betyder det att eleven ges en alternativ möjlighet att visa prov på de kunskaper eleven har, men inte visade under diskussionen, vilket är ett oklanderligt motiv. Man kan också hävda att även ett tyst deltagande i en diskussion kan vara utvecklande och en del av ett lärande. På samma 
gång, om eleven aldrig utmanas att muntligen diskutera och argumentera i grupp, kan det innebära att eleven kanske inte når sin fulla potential beträffande dessa förmågor.

En annan form av anpassning för elever som diskuterades av studiens svensk lärare var att dela in eleverna beroende på deras förmågor. En position är att om eleverna får arbeta i en grupp med elever på samma nivå skulle krav och innehåll bättre anpassas för eleverna. I en grupp med elever med starka kommunikativa och analytiska förmågor skulle eleverna möta på motstånd på samma nivå, medan elever med svagare förmågor skulle kunna få mer talutrymme i en annan grupp. Läraren kan dessutom rikta mer uppmärksamhet åt den senare gruppen eftersom mest stöd kan behövas här. Samtidigt skulle en nivågruppering betyda att man i de allra flesta grupper skulle gå miste om den positiva draghjälp som högpresterande kan ge övriga elever i klassen. En risk med nivågruppering är också att det blir en stigmatisering av vissa elever, vilket negativt påverkar deras lärande och engagemang för undervisningen. En ytterligare aspekt i sammanhanget är att det inte alltid är de elever som är högpresterande under en mer traditionell form som också är det när man arbetar med en reflexiv undervisning som i denna studie. Därigenom är det inte självklart hur man ska dela in eleverna i grupper.

\section{Fyrfältsdiagram om anpassning}

Ett fyrfältsdiagram kombinerades baserat på dessa två didaktiska dilemman om anpassning i samband med diskussioner i den reflexiva undervisningen. På den horisontella axeln i fyrfältsdiagrammet i figur 13 nedan beskrivs det didaktiska dilemmat om tysta elever ska kunna redovisa sina argument och åsikter på alternativa sätt, istället för i samband med de muntliga diskussionerna i klassrummet. På den vertikala axeln illustreras det didaktiska dilemmat om i vilken utsträckning läraren ska nivågruppera eleverna i samband med gruppdiskussioner inom den reflexiva undervisningen.

I fyrfältsdiagrammet intar lärare J en position där den kräver att alla elever deltar muntligt i diskussionerna. Läraren kan förmodas se denna förmåga som viktig att utveckla i undervisningen och ser inte 
heller denna förmåga som medfödd, utan utvecklingsbar. Lärare J är dock positiv till anpassningen i form av nivågruppering då den menar att det blir gynnsammare för eleverna. Det kan handla om att eleverna får diskutera med jämbördiga meningsmotståndare, men även om att läraren kan prioritera grupper med lågpresterande elever och ge dem mer stöd.

Även lärare I förespråkar att nivågruppera eleverna och argumenterar för att det är bra för de högpresterande i avseende på att diskutera och argumentera. Eftersom dessa elever kan inta en dominerade roll i blandade grupper ser lärare I det också som gynnsamt för övriga elever om grupper skapas utifrån elevernas förmågor. Samma lärare är även positiv till att eleverna kan få argumentera och resonera på andra sätt än muntligt. Detta kan kopplas till att lärare I ser det som viktigt att bedöma elevernas insatser i förhållande till kunskapskraven.

Inte heller lärare K ser elevernas muntliga aktivitet som något obligatoriskt att utveckla i lärarens undervisning. Det kan bero på att läraren betraktar denna förmåga som en medfödd egenskap och ingen förmåga som den prioriterar att utveckla på sina lektioner. Lärare $\mathrm{K}$ föredrar att elevgrupperna sätts samman efter andra kriterier än elevernas kunskapsnivåer. Läraren menar att det är så det är i livet och vill ha en verklighetsnära undervisning. Lärare L föredrar också heterogena grupper och ser fördelen med detta genom att högpresterande elever kan hjälpa till att lyfta övriga elever i gruppen. Lärare L ser muntlig diskussionsförmåga som en viktig förmåga för skolan att utveckla hos eleverna och kopplar detta till det demokratiuppdrag som skolan har. Dessutom menar den att muntlig förmåga är något eleverna måste tränas $\mathrm{i}$, och därför måste elever också utsättas för denna träning. 


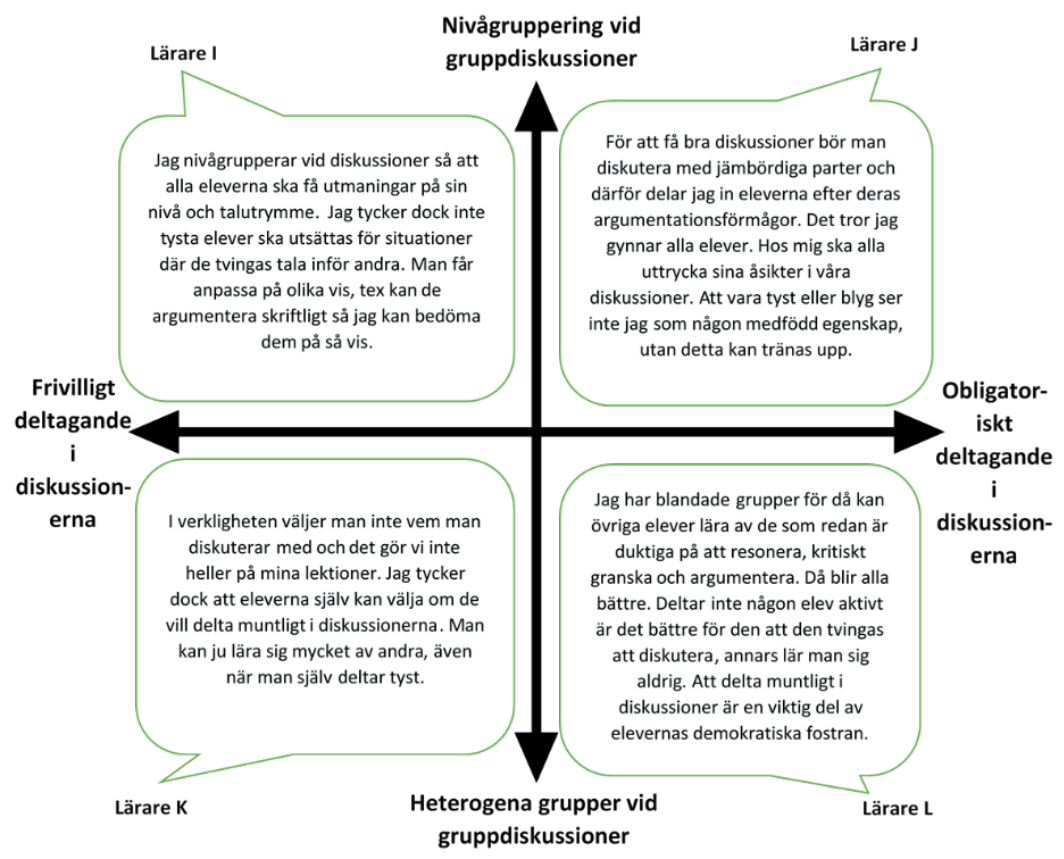

Figur 13. Fyrfältsdiagram till diskussionsverktyget kring i vilken utsträckning läraren ska göra anpassningar vid muntliga diskussioner i den reflexiva undervisningen.

\section{Diskussion kring fyrfältsdiagrammet om anpassning}

Detta fyrfältsdiagram visar att skola som verksamhet har flera motiv och syften (Alnervik, 2013) och inte endast de tre huvudsyften för utbildning som Biesta (2009) anger. Både när det gäller tysta elevers deltagande i muntliga diskussioner och nivågruppering är lärares didaktiska beslut regelmässigt gjorda i största välvilja. Varken om man väljer att tvinga alla att delta i muntliga diskussioner eller om man gör urvalsanpassade grupperingar kan det uppstå en konflikt med det omsorgsansvar läraren har för sina elever. Fransson och Grannäs (2013) skriver att lärare i klassrumsarbetet även behöver hantera en mångfald av sociala relationer och sammanhang vilka påverkar undervisningens utformning. Ett milt tvång att delta i muntliga diskussioner och kortsiktig nivågruppering skulle kunna vara gynnsamt för elevernas kunskapsutveckling (Strömquist, 2008; 
Mitchell \& Ashing, 2015), men detta måste vägas mot obehag och andra negativa effekter som kan uppstå för eleven.

Hur en lärare gör nivågrupperingar kan kopplas till vilken form av kvalificering, vilka kunskaper och förmågor, som läraren värderar högst. Är läraren i ett skolsystem där fokus ligger på innehållskunskaper från de olika skolämnena kan det vara förgivettaget att göra grupperingar efter detta. Är det större fokus på mer generiska förmågor kring resonemang, diskussion och argumentation kan det vara utifrån detta som läraren grupperar. Detta kan kopplas samman med den spänning som Carlgren (2015) ser mellan läroplanens utbildningsmål och bildningsmål och vilka kunskaper som prioriteras i undervisningen. Ser man bara till utbildningsmålen kan nivågruppering vara gynnsam, men relaterar man till skolans bildningsmål och demokratimål kan denna konstgjorda homogenisering vara mindre gynnsam.

På samma sätt som i de andra fyrfältsdiagrammen har man som lärare positioner som är förgivettagna och lärare positioneras av andra saker än bara utbildningens huvudsyften (Fransson, 2012). I alla mänskliga verksamhetssystemet finns sociala strukturer och regler som utgör en tröghet när man vill förändra sin praktik (Engeström, 2008). Dessa strukturer och regler har kommit till med goda intentioner, men om man oreflekterat följer dessa kan det uppstå effekter som inte var avsedda. Studiens svenska lärare hade en förgivettagen position att muntligt deltagande skulle vara frivilligt. Denna var inte främst grundad i omsorg om den tysta eleven, utan berodde på att muntlig förmåga inte explicit fanns med i kunskapskraven. De svenska lärarna i studien var tydligt positionerade genom att de hade ett stort fokus på att stämma av elevernas kunskaper mot kunskapskraven. För att göra detta passade resonemang och argumentation skriftligen bättre än muntliga diskussioner. Detta är i linje med det som Carlgren (2015) beskriver som baklängespedagogik och en följd av att pseudo-formativa praktiker uppstått i svensk skola (Jönsson, 2016). Ser man på bildningsmålen torde muntlig förmåga vara något väsentligt för skolan att utveckla hos alla elever inte minst med ut- 
gångspunkt i utbildningens subjektifieringsfunktion. Gör man muntligt deltagande frivilligt $\mathrm{i}$ undervisningen finns det risk att inte alla elever når sin fulla potential angående detta.

\section{Balans mellan bildningsmål och utbildningsmål}

Vilka positioner läraren intar i olika didaktiska dilemman har relationer till positioner läraren intar i andra dilemman, till andra aktörer, till normer och värderingar, till lagar och regler och till olika förgivettagna uppfattningar och handlingsmönster (Fransson, 2012). Inom skolans värld spelar de övergripande strukturerna i form av styrdokumenten en avgörande roll och positionerar inte sällan lärarna i olika dilemman. Läraren uppmärksammar troligen inte i den dagliga klassrumsundervisningen de didaktiska dilemman som finns inbyggda i läroplanen. Dock påverkar lärarens positioneringar i spänningen mellan skolans bildningsmål och utbildningsmål de positioneringar som intas i de mer klassrumsnära didaktiska dilemmana som beskrivits tidigare. För att ett diskussionsverktyg ska ge lärare och lärarstudenter möjligheter att se helheter i det komplexa verksamhetssystem som undervisningen är en del av är det viktigt att kopplingar görs även till samhällsnivån med skolans styrdokument. Vidare behöver kopplingar även göras till spänningar som ligger på mellannivåer i form av närsamhället, skolans organisation och på arbetslagsnivå. I linje med detta beskrivs studiens resultat kring olika positioner i metadilemmat rörande hur man balanserar bildningsmål och utbildningsmål i ett fyrfältsdiagram.

\section{Studiens resultat kring balans mellan bildningsmål och utbildningsmål}

I föregående kapitel diskuterades kring att lärarna på den svenska skolan beskrev att ämnenas kursplaner är det som i stor utsträckning styr deras planering av undervisningen. Lärarna återkom vid flera tillfällen till vikten av att utveckla och bedöma elevernas förmågor mot kunskapskraven. De svenska lärarna hade en stor medvetenhet om läroplanens övergripande mål och riktlinjer, men upplevde att deras handlingsutrymme allt mer begränsats och att undervisningen blivit mer ämnesinriktad. Det har blivit mer fokus på de enskilda ämnena och deras kursplaner och kunskapskrav. Samtidigt beskrev 
de svenska lärarna en annan rörelse genom att fokus på faktakunskaper skiftat till fokus på att utveckla förmågor, vilka de i stor utsträckning relaterar till kunskapskraven i ämnena. Lärarna på den svenska skolan menade att detta kan kopplas till både den nya läroplanen och till att resultaten från de nationella proven fått en större betydelse.

Flera av de positioner som de svenska deltagarna intog i andra didaktiska dilemman visade sig ha relationer till en positionering där bedömning av elevers kunskaper mot ämnenas kunskapskrav gavs stor vikt i den reflexiva undervisningen. En avgörande spänning i svensk skolkontext är vad som allra mest styr lärarens planering av undervisningen, förmågorna som uttrycks i läroplanens första delar samt i respektive ämnes syftestext eller kursplanernas centrala innehåll och deras kunskapskrav. Beträffande den reflexiva undervisningen har detta relation till hur läraren positionerar sig gällande bedömning och de olika aspekter som finns kring detta. I denna studie berörde de svenska lärarna i flera fall vikten av att bedöma eleverna i den reflexiva undervisningen, då med avseende på en bedömning för att senare sätta betyg på eleverna. Lärarna belyste de utmaningar som fanns med att göra detta. För att diskussionsverktyget ska belysa hur positioneringar kring bedömning påverkar andra positioner formuleras en överordnad spänning mellan att betygsbedöma alla elevens insatser inom den reflexiva undervisningen eller att inte samla in underlag för betygssättning alls i samband med denna form av undervisning.

De spänningar som beskrivits kring vad som styr planeringen och om eleverna ska bedömas är av dilemmakaraktär men skiljer sig en del från de övriga didaktiska dilemmana. Vad gäller de didaktiska dilemmana som direkt kan kopplas till den praktiska klassrumsundervisningen handlar det om didaktiska val mellan två mer tydliga alternativ vilka båda kan ha sina fördelar. Lärarens val kan vara olika beroende på vilket syfte läraren har med läraktiviteten. Förvisso finnas möjligheter att kombinera de olika handlingsalternativen i det didaktiska dilemmat, men de kan som regel inte verka sam- 
tidigt. När man arbetar diskuterar man antingen i grupp eller i helklass och antingen är man neutral eller inte som lärare. Givetvis kan man ibland diskutera i grupp och ibland i helklass och gällande någon fråga kan läraren ta egen ställning och i en annan hålla sig neutral. Att som lärare kunna göra dessa didaktiska val aktivt och beroende på ens syfte med aktiviteten är också grundpoängen med verktyget.

Vad gäller läroplanens och kursplanernas bildningsmål och kursplanernas utbildningsmål förhåller det sig lite annorlunda då dessa ska verka tillsammans och även samtidigt. De förmågor som uttrycks är det som ska styra planeringen av undervisningen, men samtidigt ska undervisningen stämmas av emot utbildningsmålen uttryckta i form av kunskapskrav. Det är alltså givet att det ska råda en balans mellan dessa två typer av mål i den praktiska undervisningen, men det didaktiska dilemmat gäller hur dessa två mål balanseras mot varandra. Om utbildningsmålen, i form av kunskapskraven, får en alltför stor roll finns risk att planeringen av undervisningen riktas in mot att eleverna ska visa upp tecken på kunnande av delförmågor i förhållande till beskrivningarna i kunskapskraven, i stället för att undervisningen handlar om att genuint arbeta mot att utveckla de övergripande förmågor som delförmågorna ingår i (Carlgren, 2015). Om läraren lägger för stort fokus i sin planering på utbildningsmålen och bedömning efter kunskapskraven kan det i detta sammanhang illustreras av en risk att målet blir att eleven ska visa upp en delförmåga som att lägga upp ett underbyggt argument, istället för att målet är att utveckla kunskaper för delta i diskussioner kring komplexa och kontroversiella samhällsfrågor. Att inneha kunskaper kan komma att devalveras till att visa upp kunnande.

Får däremot bildningsmålen en alltför dominerande roll och kunskapskraven hamnar i skymundan läggs stort ansvar på den enskilde lärarens professionalitet. Det finns risk att undervisningens innehåll och kvalitet kan variera från klassrum till klassrum och skolans utbildningsmål är viktiga för att motverka detta. Dessa mål ska styra utvärderingen av undervisningen. Utan ett visst fokus på utbildningsmålen kan uppfyllelse av de löften som läroplanen ger eleverna 
om en god undervisning i alltför hög grad komma att bero på lärarens kompetens, intresse och engagemang. Det didaktiska dilemmat som beskrivs i fyrfältsdiagrammet kring vad som styr lärarens planering blir en form av samvetsfråga för läraren med syfte att uppmärksamma problematiken kring att balansen skiftas för mycket åt ettdera hållet.

I det fyrfältsdiagram som valts ut här för att illustrera studiens resultat om spänningen mellan bildningsmål och utbildningsmål används spänningen mellan om man ska bedöma eleverna för att sätta framtida betyg när de arbetar med en reflexiv undervisning eller inte. Detta är inget dilemma med endast två enkelt identifierade handlingsalternativ, utan den innehåller betydligt fler aspekter. Detta kan exempelvis gälla hur man ska bedöma och vilka delar man kan bedöma och för att gå på djupet med detta behövs fler fyrfältsdiagram.

Vad gäller att sätta betyg på eleverna är detta ett myndighetsuppdrag för lärare från årskurs 6 och uppåt och för att kunna sätta ett betyg som allsidigt utvärderar varje elevs kunskaper i förhållande till kunskapskraven måste läraren kontinuerligt dokumentera elevernas kunskaper. Sett ur detta perspektiv kan det verka självklart att även elevens insatser inom den reflexiva undervisningen ska kunna vara underlag för betygssättning. En reflexiv undervisning kan väcka elevernas engagemang och under arbetet med kontroversiella frågor kan eleverna visa prov på förmågor som motsvarar kunskapskraven på hög nivå och det är då rimligt att någon elev vill kunna tillgodoräkna sig detta. En undervisning med mer muntlig aktivitet och mer aktivt elevdeltagande kan också bättre passa vissa elever jämfört med en mer skriv- och läsinriktad undervisning. För dessa elever kan det vara orättvist om inte deras uppvisade resultat här kan vara en grund för betygssättning.

Den reflexiva undervisningen har dock en tydligt ämnesövergripande utformning och en tydlig inriktning mot läroplanens demokratimål samt mot att skapa utrymme för elevernas subjektifiering genom att få utveckla sin egenart och ta egen ställning. Då betygssättningen görs ämnesvis menar Andrée och Lundegård (2013) att 
bedömning för betygssättning begränsar eleverna möjligheter att ta egen ställning och att utmana gällande ståndpunkter i samhället. När eleverna arbetar med kontroversiella samhällsfrågor i den naturvetenskapliga undervisningen visar Nielsen (2012b) att elever ofta föredrar ekonomiska och sociala argument framför de naturvetenskapliga och att de även influeras starkt av olika värderingar. Det blir ett dilemma för en ämneslärare om den ska bedöma utifrån ämnets kunskapskrav. Det uppstår en frågeställning om exempelvis en NO-lärare kan bedöma en elevs förmågor att diskutera kring en samhällsfråga om eleven väljer att argumentera utifrån andra perspektiv än de rent naturvetenskapliga. En aspekt är om det finns generella förmågor beträffande att argumentera och resonera som läraren i ett ämne kan bedöma, även om eleven argumenterar i ett annat ämne kring ett annat ämnesinnehåll.

\section{Fyrfältsdiagram om olika typer av mål}

Fyrfältsdiagrammet i figur 14 nedan ämnar främst att övergripande belysa hur positioner beträffande läroplanens bildningsmål och utbildningsmål samt gällande bedömning för betygssättning påverkar didaktiska dilemman i den konkreta klassrumspraktiken. Detta fyrfältsdiagram kan alltså ses som ett viktigt komplement till övriga, men måste användas i sitt sammanhang.

I fyrfältsdiagrammet kan det förmodas att lärare N:s planering styrs mycket av kunskapskraven och läraren motiverar detta genom att det skapar en likvärdig undervisning. Lärare $\mathrm{N}$ använder inte denna form av undervisning som underlag för en bedömning i ämnet då läraren ser en problematik med att innehållet i frågan inte alltid är något som ingår i det centrala innehållet i lärarens ämne. Läraren menar att bedömning för betygssättning i ämnet måste relatera till ett innehåll från ämnet. Vad gäller detta har lärare $M$ en motsatt åsikt eftersom den ser vissa förmågor som mer generella och som möjliga att bedöma även om ämnesinnehållet är något annat. Lärare M:s undervisning förfaller annars vara starkt påverkad av vad som står i ämnets centrala innehåll och känner en press att täcka in alla bitar av detta. För lärare $\mathrm{O}$ är det bildningsmålen i läroplanen som är de viktiga och läraren verkar inte ta så hårt på ämnenas centrala 
innehåll. Även om undervisningen är ämnesövergripande använder lärare $\mathrm{O}$ denna för att få underlag till framtida betygssättning och menar att det kan vara gynnsamt för de elever som just denna undervisningsform passar för. Lärare $\mathrm{P}$ utgår ifrån de övergripande förmågorna i sin planering och tittar endast på kunskapskraven när läraren ska bedöma eleven inför betygssättningen. Lärare P väljer emellertid inte att samla in underlag och betygssätta eleverna baserat på den reflexiva undervisningen. Detta eftersom läraren anser att det innebär en stor risk att inte eleverna skulle känna sig fria att ifrågasätta givna samhällsstrukturer och ta egen ställning i frågorna.

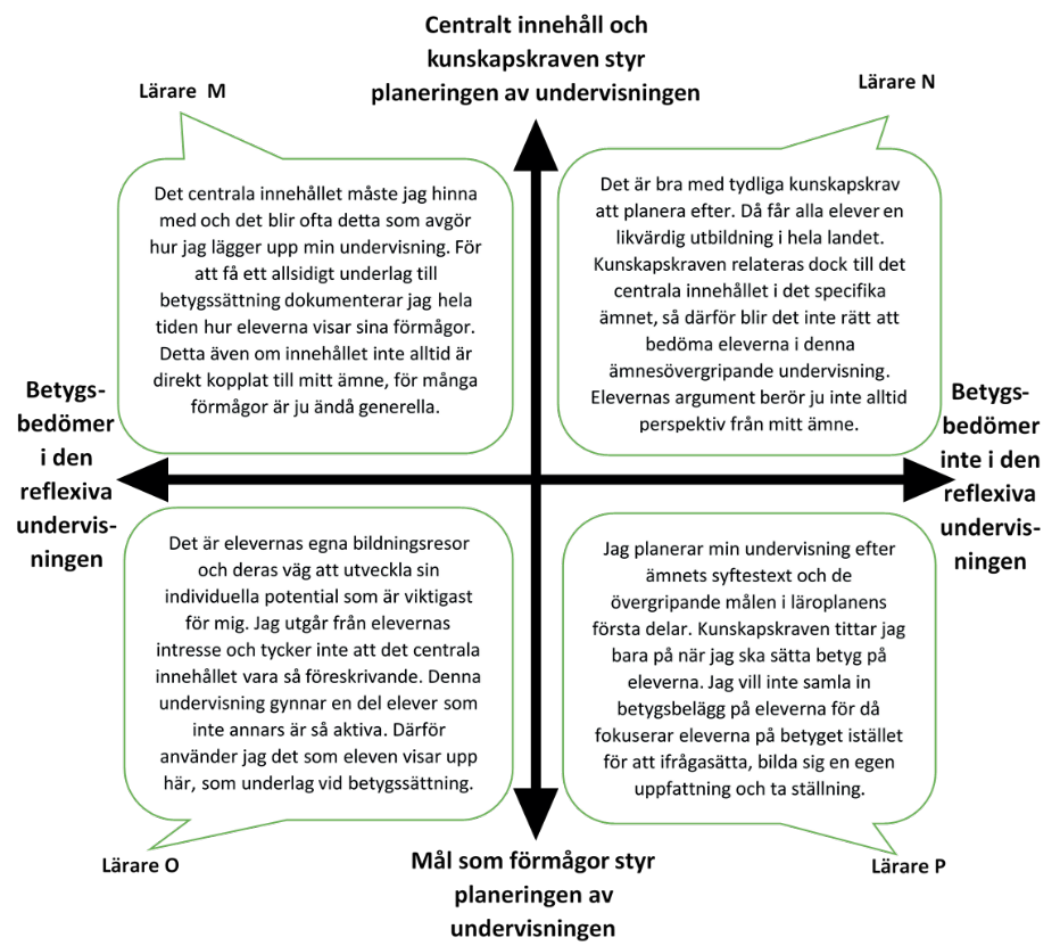

Figur 14. Fyrfältsdiagram till diskussionsverktyget kring läroplanens olika mål och bedömning för betygssättning i den reflexiva undervisningen. 


\section{Diskussion kring fyrfältsdiagrammet om balans mellan bildningsmål och utbildningsmål}

Hur man positionerar sig i de övriga fyrfältsdiagrammen kan relateras till spänningen mellan läroplanens bildningsmål och utbildningsmål. Carlgren (2015) menar att utbildningsmålen handlar om att eleverna ska få kunskaper och verktyg de kan använda sig av i olika sammanhang, medan bildningsmålen handlar om att eleverna förändras och förädlas till självständiga, tänkande och reflekterande människor som använder kunskaperna och verktygen på förnuftiga sätt. Sjöström (2013) menar att en bildningsorienterad nv-undervisning omfattar etiska och politiska dimensioner och fokuserar på problematisering, metaperspektiv och sociopolitiska handlingar. Denna kritisk-reflexiva bildning utgår ifrån att bildning är det som fritänkande och medvetna medborgare behöver i ett demokratiskt och hållbart samhälle (Sjöström m.fl., 2017). En undervisning som planeras med utgångspunkt från bildningsmålen blir en undervisning där det finns möjlighet att arbeta mot utbildningens subjektifieringsfunktion (Biesta, 2012a).

Lärarna i denna studie visade full medvetenhet om vikten av en bildningsorienterad undervisning och att eleverna bör få utrymme för subjektifiering. I lärarnas syfteskomplexa vardag gjorde emellertid lärarna en hel del förgivettagna didaktiska val som begränsade detta utrymme. Fokus i undervisningen hamnade istället på att uppnå utbildningsmål. Fyrfältsdiagrammet belyser att den balans mellan utbildningsmål och bildningsmål som går att formulera i teorin är betydligt svårare att åstadkomma i praktiken. I det dilemmatic space som den reflexiva undervisningen bildar påverkas lärarens beslutsfattande av tolkningar av styrdokument, undervisningstraditioner och normer, tidigare erfarenheter samt det omgivande sociala sammanhanget (Fransson \& Grannäs, 2013). Inneboende spänningar mellan olika delar och på olika nivåer inom undervisningens verksamhetssystem, och mot närliggande verksamheter, uppstår ofrånkomligen (Engeström, 1987). När dessa motsättningar blir synliga i praktiken menar Engeström och Rückriem (2005) att de dock inte ska ses som problem, utan som utgångspunkter för en förändrad och förbättrad praktik. 
Den didaktiska modellen med dessa fyrfältsdiagram kan stödja lärare att uppmärksamma didaktiska dilemman som uppstår i undervisningens syfteskomplexitet och hjälpa till att få syn på förgivettagna positioner. Undervisning i stort är multimotivdriven (Alnervik, 2013) och inom den reflexiva undervisningen finns därför flera syften att hantera. Lärarens handlingar och operationer i undervisningen är inte alltid relaterade till syften som är medvetandegjorda hos läraren (Chaiklin, 2007). Om lärarens beslutsfattande görs efter förgivettagande positioner riskerar därmed didaktiska val i relation till ett syfte att få oönskade konsekvenser i förhållande till andra syften. Studien visar att de svenska lärarna upplevde sig styrda av kunskapskraven och flera gånger återkom till vikten av att samla in underlag att eleverna visat upp de tecken på förmågor som formulerats i ämnenas kunskapskrav. Det ligger i läraruppdraget att eleverna ska nå utbildningsmålen och läraren ska stämma av elevens kunskaper mot kunskapskraven. Men om läraren lägger alltför mycket fokus på utbildningsmålen och betygsbedömning finns risk för att bildningsmålen blir alltför nedtonade och att utrymmet för eleverna att förädlas till självständiga, tänkande och reflekterande människor minskar.

\section{Summering av fyrfältsdiagrammen}

Till vart och ett av de fyra metadilemman som växte fram under analysen omformades resultaten om de didaktiska dilemmana till fyrfältsdiagram. Dessa är tänkta att fungera som ett underlag för kollegiala lärardiskussioner om fördelar och nackdelar med olika positioner i didaktiska dilemman i den reflexiva undervisningen. De är i kapitlet presenterade i en tänkt sekvens som en lärargrupp skulle kunna arbeta med i ett kollegialt lärande. Det första fyrfältsdiagrammet belyser arbetsformen under en reflexiv undervisning med avseende på i vilken grad läraren ska förmedla fakta och information kring det aktuella samhällsdilemmat samt i vilken utsträckning eleverna ska arbeta i mindre grupper i förhållande till en helklass. 
Fyrfältsdiagrammet kring arbetsform vill bidra till en kollegial diskussion om hur balansen ser ut mellan elevcentrerad och lärarcentrerad undervisningen. Det val läraren gör beror till stor del på vilket syfte läraren har. Är syftet att utveckla elevernas generella förmågor kring kritiskt tänkande, och det aktuella samhällsdilemmat endast är ett medel för att göra detta, kan eleverna ges mer eget ansvar i undervisningen och mer svängrum i beslutsfattande och diskussioner. Vilka beslut eleverna fattar får en underordnad roll när aktivitetens syfte är att förbereda eleverna för att kunna ta ställning till andra samhällsdilemman i framtiden. Är syftet att eleverna verkligen ska få möjlighet att ta ställning, och få en djupare förståelse kring ett aktuellt samhällsdilemma, behöver eleverna stöttning av läraren för att skaffa sig tillräckligt med kunskaper och information om samhällsfrågans olika aspekter. I så fall kan det vara rimligt att läraren intar en större roll och tar ett större ansvar.

Det andra fyrfältsdiagrammet berör lärarnas ställningstaganden och kan kopplas samman med det föregående. I vilken grad läraren framförallt blir partisk i diskussioner hänger samman med lärarens syfte med undervisningen. Att välja att argumentera emot eleverna ståndpunkter, även om det inte sker utifrån lärarens egna åsikter, kan göra att elevernas argumentations- och diskussionsförmågor utvecklas. Det kan dessutom vara en metod för att bredda en diskussion och ge eleverna alternativa synsätt kring samhällsdilemmat. När läraren är partisk i diskussionerna kan det innebära att själva frågan i sig, och vad som kan anses som ett välgrundat ställningstagande, hamnar i bakgrunden till förmån för förmågeträning. Innan läraren intar en roll som djävulens advokat i klassrummet är det därför viktigt att denne har funderat över det aktuella syftet. Huruvida läraren intar en fiktiv motsatt ställning jämfört med eleverna i diskussionerna hänger vidare samman med om läraren delar med sig av sina personliga åsikter i klassrummet eller håller sig neutral. Att vara helt neutral som lärare är svårt och åsikter kan skina igenom. Är man neutral eller alltför perspektivorienterande kan detta innebära att lärarens möjlighet att hjälpa eleverna att införliva samhällets normer och kultur för att stärka samhällets och elevernas förmåga att leva i detta begränsas. 
Fyrfältsdiagrammet kring anpassning belyser två didaktiska dilemman gällande om läraren ska nivågruppera eleverna i den reflexiva undervisningen samt i vilken grad muntligt deltagande i diskussionerna ska ses som frivilligt eller obligatoriskt. De tänkta lärardiskussionerna ska beröra huruvida dessa val av anpassningar kan gynna eller missgynna elever som inte självmant tar en aktiv del muntligt i den reflexiva undervisningens diskussioner. I beslutsfattandet kring i vilken grad man som lärare ska utmana dessa elever att delta muntligt måste läraren även väga in personliga och sociala aspekter. När det gäller att gruppera elever kan det finnas fördelar med att elever arbetar med andra elever på ungefär samma nivå, samtidigt som det även finns nackdelar. Att låta elever som är på samma nivå diskutera samhällsdilemman kan ses som ett gynnande respektive missgynnande av olika kategorier av elever. För elever med välutvecklade förmågor kan nivågruppering erbjuda dem större utmaningar. En nivågruppering kan även ses som gynnsam för svagare elever då de kan få mer talutrymme och även potentiellt mer lärarstöd. Samtidigt kan eleverna som placeras i en svag grupp uppleva detta som självuppfyllande. Om dessa elever istället skulle varit i en heterogent sammansatt grupp skulle de med hjälp av starkare elever kunnat utvecklas mer. Fyrfältsdiagrammet vill stödja lärare att nyanserat reflektera kring både potentiella möjligheter och negativa konsekvenser med anpassningar av undervisning kring detta område där det är lätt att ha starka och förgivettagna uppfattningar.

I diskussionerna kring detta fjärde fyrfältsdiagram är tanken att man ska kunna koppla samman detta med de tidigare. Metadilemmat rörande hur lärare ska förhålla sig till läroplanens olika typer av mål är kanske egentligen inget dilemma. Intentionen i den svenska läroplanen är att det är förmågorna som ska styra planeringen av undervisningen medan kunskapskraven ska användas i utvärderingen av undervisningen. Samtidigt kan alltför stort fokus på bedömning, nationella prov eller traditionella konventioner kring att förmedla ett förutbestämt kunskapsstoff innebära att lärarnas planering $i$ praktiken styrs av centralt ämnesinnehåll eller av att träna eleverna att visa upp de tecken på kunnande som kunskapskraven beskriver. 
Till skillnad från de övriga fyrfältsdiagrammen har inte det sista fyrfältsdiagrammet konkreta didaktiska val att ta ställning till riktigt på samma vis. Det didaktiska dilemmat om läraren ska samla in betygsunderlag eller inte under den reflexiva undervisningen kan förvisso ses som konkret, men då bedömning av elever har många aspekter kan detta dilemma egentligen delas upp i flera underdilemman. De kan beröra olika former av bedömning och huruvida förmågor måste relateras till en viss ämneskontext. I fyrfältsdilemmat är tanken att detta didaktiska dilemma ska medföra en inledande diskussion kring de ofta förgivettagna positionerna angående bedömning i den svenska skolan. Detta kan sedan leda in på fördjupade diskussioner kring bedömning.

Precis som när det gäller övriga didaktiska dilemman handlar det som lärare om att hitta en balans mellan positionerna och justera ens balanserade position efter vilket syfte som man har med den aktuella undervisningen. Den position som läraren intar kring ett dilemma kan påverka positioner i de övriga dilemmana och därav kan detta fyrfältsdiagram hjälpa till att knyta samman alla fyra som presenterats här. Om läraren har ett alltför stort fokus på att förmedla ett bestämt ämnesinnehåll kan detta hamna i fokus när man arbetar med samhällsdilemmat och själva processen kring att ta ställning i frågan och förmågor kring dessa tonas ner. Har läraren för stort fokus på att bedöma eleverna och utvärdera eleverna efter kunskapskraven kan utveckling och uppvisande av dessa förmågor få alltför stort utrymme, vilket kan inverka på elevernas möjlighet att ta en välgrundad ställning i samhällsdilemmat. Ett stort fokus på kunskapskravens aspekter kan även påverka läraren till att inta en svagt objektiv roll i muntliga diskussioner för att genom detta stödja elevernas förmågeutveckling och samla underlag för betygssättning. Om läraren i en reflexiv undervisning lägger större vikt på att utvärdera tysta elevers förmågor att argumentera och resonera än på att eleven ska utveckla sin muntliga förmåga är det rimligt att den tyste eleven erbjuds anpassning så att den slipper agera muntligt.

Ovannämnda positioner ska inte betraktas som ett sämre alternativ utan poängen med fyrfältsdiagrammen är att visa att vilken position 
som är att föredra beror på vilket syfte läraren har med den reflexiva undervisningssekvensen. Eftersom de olika didaktiska dilemmana i den reflexiva undervisningen har relation till varandra, där en position påverkar en annan, är det fundamentalt att läraren klargör vilket eller vilka syften som är prioriterade i just den reflexiva undervisning som planeras. De olika syftena kan stå i motsättning till varandra i olika delar av undervisningen och är man inte uppmärksam på detta som lärare kan undervisningens resultat bli negativa trots goda intentioner. Med kollegiala diskussioner kan lärares praktiska kunskap kring dessa didaktiska dilemman i en reflexiv undervisning byggas upp och den enskilde lärarens handlingsrepertoar kan utökas så att läraren därigenom kan fatta allt bättre didaktiska beslut i den komplexa skolvardagen.

Förslag till framtida studier av andra didaktiska dilemman

Under analysen i studiens tredje fas fanns även andra spänningar med inneboende didaktiska dilemman som potentiellt skulle kunna fördjupas och omformas till fyrfältsdiagram för ett diskussionsverktyg. Till en del rör det sig om dilemman som empiriskt beskrevs under studiens första fas, både sådana som visade sig i samband med de deltagande observationerna under temadagarna inom Erasmus+ partnerskapet och spänningar som beskrevs under fokusgruppsintervjuerna. Vidare är det också spänningar som de svenska lärarna berörde under den komparativa fokusgruppsintervjun i studiens andra fas, vilka analyserades under fas III. Inom ramen för denna studie fördjupades emellertid inte dessa spänningar och didaktiska dilemman djupare, utan fokus lades på de som presenterades ovan. Nedan presenteras kortfattat fler spänningar som läraren kan behöva hantera $\mathrm{i}$ en reflexiv undervisning och som skulle kunna fördjupas i framtida studier.

\section{Kall eller het undervisning}

En spänning som uppstår när man arbetar med samhällsdilemman är att de är så komplexa att de kräver en hel del olika kunskaper för att kunna överblicka frågan. Dessutom räcker det som regel inte att man har ämneskunskaper i ett skolämne, eftersom frågorna som re- 
gel är tvärvetenskapliga. När samhällsfrågan har ett naturvetenskapligt innehåll kan det krävas att eleverna har vissa kunskaper för att på djupet förstå frågan. Detta kan innebära att läraren gör ett didaktiskt val att ge eleverna en del förberedande undervisning om innehållet innan själva frågan behandlas. Samtidigt är själva idén med SNI-undervisning att arbetet med frågan ska göra att eleverna får ett engagemang och intresse att utveckla dessa ämneskunskaper (Ekborg m.fl., 2012). När ett specifikt ämnesinnehåll får för stort utrymme i undervisningen finns en risk att den kontroversiella samhällsfrågan blir endimensionell och svaren endast söks inom det aktuella ämnet. Åkerblom och Lindahl (2017) pekar på att lärare måste hitta en balans mellan två sorters informellt resonemang. Läraren behöver tillåta att eleverna använder en vardagsdiskurs och resonerar mer emotionellt då detta gör att eleverna blir engagerade i undervisningen. Samtidigt behöver läraren stötta eleverna att bygga upp ett mer rationellt resonerande.

En undervisning kring samhällsfrågor med naturvetenskapligt innehåll som främst syftar till att lyfta fram olika naturvetenskapliga och tekniska begrepp och principer kallar Simonneaux (2014a) för en kall SNI. I andra änden av ett kontinuum beskriver hon en het SNI, där även perspektiv från andra ämnesområden tas in på samma premisser, precis som sociopolitiska och filosofiska aspekter. I en het SNI är kritiskt tänkande, argumentation och ställningstagande delar som får mer utrymme i undervisningen. Den reflexiva undervisningen inom denna studie är i den heta änden av Simonneauxs SNIkontinuum. Det kan också finnas goda argument för en lärare att välja en undervisning i linje med en kall SNI, exempelvis om lärarens huvudsakliga syfte med undervisningen är att eleverna ska lära sig en naturvetenskaplig förklaringsmodell av ett fenomen.

Det räcker som regel inte att man har ämneskunskaper i ett ämne eftersom frågorna ofta är tvärvetenskapliga. Ju hetare samhällsfrågorna är desto mer kommer värderingar, attityder och känslor in i diskussionerna och Eriksson och Rundgren (2012) pekar på att elever ofta har svårt på att skilja på fakta och värderingar om de inte uppmärksammas på detta. Detta didaktiska dilemma har en relation 
till metadilemmat som beskrivs som en spänning mellan elevcentrerade och lärarcentrerade arbetsformer. De svenska lärarna i studien hade visserligen inför temadagen introducerat eleverna till de ämnesområden som frågorna skulle beröra. Under temadagen lämnades emellertid mycket av ansvaret för att samla in mer specifik kunskap om frågeställningen till eleverna själva. Möjligheten för eleverna att få del av relevanta ämneskunskaper var mindre om man jämför med eleverna på exempelvis den polska skolan. Här var lärarna mer förmedlande och var den primära källan till information om olika aspekter kring frågan. De polska lärarna var ämneslärare i olika ämnen och vävde därmed naturligt in relevanta ämneskunskaper till en viss del.

När eleverna från olika länder tillsammans under elevutbytena diskuterade de komplexa och kontroversiella frågorna var studiens lärare överens om att exempelvis de polska eleverna i flera fall hade bra och välgrundade argument. Detta kan ställas i relation till de svenska eleverna som förvisso hade många argument med sig men som inte alltid hade ett stort djup och ofta var argumenten sammanvävda med mer känslomässiga ståndpunkter. De svenska elevernas argument var argument som var baserade mer på en personlig process av ställningstaganden och man kan tolka det som att detta bidrog till att de svenska eleverna därför var mer övertygade om sin sak i diskussionerna. De polska elevernas argument var ur ett lärarperspektiv bra och välgrundade, men dessa hade tillkommit mer genom en socialiseringsprocess som en följd av lärarnas undervisning. Det var goda argument men nödvändigtvis inte argument som eleverna gjort till sina egna. Detta kan i så fall förklara att de polska eleverna inte hade samma övertygelse och intensitet i diskussionerna, trots att de egentligen hade bättre och mer relevanta argument med sig.

Spänningar finns kring hur, och i vilken grad, man ska väva in olika ämneskunskaper i en undervisning kring komplexa och kontroversiella samhällsdilemman. Det beror på vilket syfte läraren har med att ta upp frågan i undervisningen. Är det för att illustrera exempelvis ett naturvetenskapligt begrepp eller fenomen kan det vara rimligt 
att ge eleverna en del grundkunskaper i ämnet för att eleverna ska få tillräcklig förståelse. Detta ämnesfokus innebär emellertid att elevens möjlighet att ta in kunskaper från andra ämnen och vardagskunskaper i övrigt begränsas, precis som utrymmet för eleven att göra personliga ställningstaganden. Detta utrymme blir större om man väljer en hetare undervisning där mer fokus läggs på frågans olika aspekter och inte bara på ett förutbestämt ämnesinnehåll. I denna form av undervisning riskerar emellertid elevernas utvecklande av specifika ämneskunskaper att få stå tillbaka. Kopnina (2012) pekar på att det finns en risk med överdriven inriktning mot pluralism i undervisningen genom att ekonomiska och sociala aspekter kommer i förgrunden på bekostnad av miljömässiga aspekter. Detta kunde man se tecken på i den svenska undervisningen och de svenska elevernas argument. Det finns en relation mellan hur lärare placerar in sig i ett didaktiskt dilemma kring het och kall undervisning och hur de positionerar sig kring spänningen mellan läroplanens bildningsmål och utbildningsmål.

\section{Tillit till eller misstro mot expertis och lagar}

I en reflexiv undervisning tas alla olika perspektiv med i diskussionerna och olika åsikter släpps fram, men samtidigt måste man givetvis även här skilja fakta baserad på evidens och rent tyckande. Biesta (2009) påpekar att undervisning som också har som funktion att utveckla eleverna till självständiga och kritiska individer ifrågasätter den gällande sociala ordningen. På samma gång som naturvetenskapen är empirigrundad, ska den hela tiden kunna ifrågasättas. Förvisso kan man inte ifrågasätta naturvetenskap bara baserat på personliga åsikter utan man måste ha en grund för detta. När det gäller samhällsdilemman har de dock flera aspekter där de vetenskapliga perspektiven inte ensamma kan svara på frågan. En spänning finns mellan i vilken utsträckning man ska förlita sig på experter eller om man ska ha en viss misstro gentemot denna expertis. Denna spänning är parallell med ett didaktiskt dilemma som läraren kan hamna inför gällande huruvida en fråga ska behandlas som kontroversiell eller inte. Det faktum att jorden är ett klot är uppenbarligen inte något som är kontroversiellt. Någonstans längs kontinuum mot genuint kontroversiella frågor blir det svårt att avgöra om en 
fråga kan betraktas vara ett etablerat faktum eller inte. När det gäller frågor som berör religion eller sexualitet kan det finnas en vetenskaplig enighet, men människors värdesystem kan ändå göra frågorna kontroversiella. Även om dessa värdesystem egentligen inte har med frågan att göra finns de i samhället och påverkar oss och därför kan det vara rimligt att de ändå berörs i skolan.

I: Vad är det om det är kontroversiellt? Ska vi ta upp skapelse eller evolutionen och ska vi behandla detta som kontroversiell eller är det så att fakta är vetenskap.

Annika: Ibland kommer det upp så och jag kan också ta upp det och så och belysa att det finns, men inte att vi inte riktigt vet om det här.

Simon: Det är väl det som är det fina att man lär sig på något vis med fakta, men sedan finns det en del att man ska tro till en viss del.

Annika: Det är exakt vad jag säger, man får tro vad man vill.

Simon: Det är ju egentligen inte något som går emot varandra för det finns ju väldigt framstånde naturvetenskapliga forskare som är religiösa och vet att så här har det gått till, men jag tror så här. Det är det här som är tro.

På samma gång kan det beträffande en del frågor finnas åsikter i samhällsdebatten som menar att vissa frågor inte bör betraktas som kontroversiella. I studien diskuterades exempelvis samkönade pars rätt att få bli prövade som adoptivföräldrar. Sedan länge är det lagligt i Sverige och en stor acceptans finns för detta. I de övriga länderna i studien finns inte samma stöd i lagen och därmed är frågan betydligt mer kontroversiell där. Eftersom det är lagstadgat i Sverige kan man ställa sig frågan om man därmed inte bör ta upp en fråga som denna till diskussion och behandla den som kontroversiell. Man kan med visst fog hävda att frågan redan är avgjord och att saken inte bör ifrågasättas då man beslutat om detta i demokratisk form 
som att en diskussion om detta skulle ge utrymme för avvikande åsikter i frågan att frodas.

Delar man åsikten som gäller i lagen kan man dock även se på det från det andra hållet och hävda att det är viktigt att ständigt diskutera frågor som dessa. Det finns exempelvis opinion mot samkönade pars adoptionsrättigheter i Sverige, men kanske framförallt i övriga världen. Om man inte ständigt diskuterar frågan kan dessa åsikter ta överhand även i Sverige. När det gäller kontroversiella frågor och samhällsdilemman förändras gällande åsikter över tid och med samhällets utveckling. Att begränsa samhällsdebatten genom att betrakta vissa åsikter som per definition rätta och andra per definition som fel kan vara ett större hot mot demokratin, än åsikterna i sig. Detta är kärnan i vad subjektifiering handlar om.

\section{Hantering av extrema åsikter}

När diskussioner inom en reflexiv undervisning kommer in på närliggande ämnen kan elever yttra extremare åsikter som kan skapa kontroverser i klassrummet bortanför det som läraren avsett. Amnå m.fl. (2010) skriver att läraren då ställs inför ett dilemma om den ska lyfta upp kontroversen och diskutera med hela klassen eller om man ska avisa denna diskussion i klassrummet, för att sedan tala om saken med eleven enskilt. Spänningen relaterar till metadilemmat kring objektivitet och neutralitet i klassrummet och berör klassrumssituationer som uppkommer spontant där yttrandefrihet och åsiktsfrihet hamnar i konflikt med grundvärderingen om allas lika värde.

I: Ska man tillåta alla åsikter?

Mikael: Svår fråga. Ibland så har man läge så trycker man ju gärna till om någon har några extrema åsikter, men det är egentligen det är att det är läget och magkänslan man går efter.

Annika: Jag tycker det är svårt och diskuterar, eller att elever för fram rasistiska åsikter när det sitter invandrarelever i klassen. Det klarar inte jag om man ska vara ärlig. 
John: Det är också det här att skulle man acceptera om någon står och pratar om en religiös världsbild istället för något som är grundat i vetenskap så självklart är det jobbigt att lyssna på.

Annika: Men där tycker jag att vi har naturvetenskaplig del men religionen kan gå emot, men här i skolan ska vi lära oss den naturvetenskapliga delen.

Amnå m.fl. (2010) kopplar i ett fyrfältsdiagram samman lärarens kontroversacceptans med vilken kommunikativ strategi läraren använder i den uppkomna situationen. Antingen kan läraren öppna upp för en normdialog med ett öppet och pluralistiskt diskussionsklimat eller inta en mer normförmedlande roll. I den senare rollen är läraren tydlig med att förmedla samhällets gällande normer och hänvisar eventuellt till aktuella lagar. Genom att istället öppet ta upp det med hela klassen kan det bli ett autentiskt tillfälle för att diskutera samhällsdilemman. Samtidigt finns en risk att en oförberedd diskussion i en alltför öppen anda kan leda till att fördomar byggs på istället för motverkas och starka känslor kan röras upp.

I och med att läraren ska stå upp för skolans värdegrund i klassrummet innebär detta att läraren måste ta ställning i vissa frågor. Därmed påverkas också diskussionsutrymmet för eleverna i klassrummet. Om läraren å andra sidan har låg acceptans för kontroverser förhindras fortsatta diskussioner i klassrummet kring kontroversen. Läraren kan göra detta val för att det inte passar in i den pågående undervisningen eller för att inte några elever i klassen ska känna sig kränkta av den uttryckta åsikten. Amnå m.fl. (2010) pekar på att genom att läraren inte prövar den extrema åsikten i en offentlig diskussion innebär det att eleverna dels går miste om en möjlighet att pröva sina egna argument och dels att ta ställning i frågan. Genom att inte ta upp frågan kan de elever som delar den extrema åsikten se det som en bekräftelse på att de har rätt. Talar läraren enskilt med eleven kan den visa för eleven att åsikten inte gick obemärkt förbi och Amnå m.fl. pekar på två alternativa strategier som kan urskiljas här. Antingen intar läraren en fostrande roll genom att föra en dis- 
kussion med eleven eller en mer avvisande roll och visar tydligt avståndstagande och är avvisande till en fortsatt diskussion i ämnet. Läraren måste anpassa sin strategi beroende på den aktuella situationen.

\section{Samtalstyp i klassrummet}

Wahlström (2015) anger två grundläggande ideala typer av kommunikation i klassrummet, seminariesamtal och deliberativt samtal. Hon kopplar detta till att läroplanens utformning påverkar lärarnas positioner beträffande dessa två typer. Seminariesamtalet håller sig på en mer analytisk och akademisk nivå och diskuterar frågeställningen från allmänna principer. Detta till skillnad från ett deliberativt samtal där man fokuserar mer på konkreta problem och ändamålet med diskussionen är mer handlingsinriktat. Man kan givetvis diskutera en fråga både på ett allmänt och analytiskt vis, samtidigt som man också kan gå in mer på konkreta och aktuella frågeställningar och försöka hitta lösningar på dessa konkreta problem. I en undervisningssituation kan man börja med att utforska och belysa en fråga utifrån allmänna principer för att sedan fördjupa elevernas kunskaper. Då börjar man i ett seminariesamtal för att sedan gå över i ett handlingsinriktat deliberativt samtal. Wahlström påpekar att båda har sin plats i undervisningen. Dilemmat handlar likt de övriga om vad läraren prioriterar mest i klassrummet.

De samhällsdilemman som lärarna inom studien arbetade med var förutbestämda och gemensamma och varje skola skulle inför de gemensamma utbytena ta fram sina egna förslag till handlingsalternativ. Därmed var lärarna delvis styrda mot en mer deliberativ samtalsform men samtidigt kunde de välja att föra in diskussionerna mer på en resonerande och akademisk nivå där fokus hamnar mer på frågan "vad betyder dessa olika alternativ" snarare än "hur kan vi göra för att lösa detta problem". Man kunde i arbetet under temadagen och i uttalanden under fokusgruppsintervjuerna urskilja att de svenska lärarna ville att eleverna skulle lyfta upp frågorna på en mer analytisk och utforskande nivå.

Jag tror att man kan säga så att man jobbar i mångt och mycket 
att lära dem att bygga ett resonemang som läromedlet tar fram och sedan kanske man hittar några tidningsartiklar där den forskaren uttryckt sig och där har den politikern uttalat sig så att det inte blir utifrån eleven utan de ska lära sig hur andra resonerar kring en sakfråga. Det tycker jag är rätt så lämpligt så då blir det att man utgår från rätt allmänna principer. (John, Sverige)

Att studiens svenska lärare intar en position där seminariesamtalsformen får utrymme kan förstås utifrån hur de svenska läroplanerna skriver fram den ideala formen av den "rättviseorienterande medborgaren" (Wahlström, 2015). Hon skriver att det blivit en förskjutning från ett aktivt, samhällsengagerade och deltagande medborgarideal i Lgr 80 till ett med distanserat och akademiskt resonerande ideal i Lgr 11. Om seminarieformen blir alltför dominant får eleverna förvisso en fördjupad förståelse för frågan men de riskerar att bli passiva och mindre handlingsinriktade vad gäller att lösa samhällsdilemman. En alltför tydlig tyngdpunkt på deliberativa samtal kan göra att eleverna blir radikala och handlingsorienterade, men risk finns att elevernas argument är grunda och oreflekterade när de inte fått tillräckligt stöd att förstå och analysera alla de aspekter som frågan innehåller.

\section{Konflikt eller konsensus}

När eleverna diskuterade kring samhällsdilemmana upplevde studiens svenska lärare att deras elever till stor del var inriktade mot att konsensus skulle uppnås. Eleverna var inriktade på att övertyga de andra i diskussion om sina idéer och få dem att hålla med. Lärarna upplevde det som om man som svensk lärare socialiserats in i en norm där det är viktigt att konsensus och samförstånd nås i en diskussion.

I: Finns det inget bra i att de försöker övertyga varandra?

Simon: Men det är väl lite motsägelsefullt. Det är klart att de ska försöka övertyga varandra, men man behöver ju inte komma till konsensus. Det är ju som John säger man får ju tycka lite vad man vill. 
John: Men det verkar nästan som de är skolade i att det ska vara konsensus. Det är samförståndspolitik på nationell nivå också och alla partier går mot mitten och det är där man hämtar upp sin väljarkader.

Simon: De flesta människor är förhållandevis rädda för konflikt.

\section{I: Varför?}

Simon: Jag tror att i vårt samhälle skolas man sen förskolan att allt ska vara konsensus, man ska alltid komma fram till att "nu är det bra”.

John: Samförståndet är viktigt.

Simon: Sedan får vi rätt så många nyanlända barn nu till exempel som kommer från ett lite annorlunda system. Några av dem kan också använda sig av "sitt sätt att vara" genom att prata rätt så högt, genom att skrika rätt så mycket om egentliga skitsaker. Det gör att läraren nästan backar lite, "här är det farligt". Men de kommer från ett system där man blir ovänner som satan, men sedan har man glömt bort det.

Mikael: På våra förskolor kommer vuxen personal och reder ut allting och diskuterar i all oändlighet.

Simon: Det är en stor, stor baksida.

Annika: Sedan bara slog det mig att har inte heller haft krig på många hundra år.

John: Det är vårt geopolitiska läge också.

Spänning mellan konsensus och konflikt i diskussioner i pluralistisk anda belyses av Todd (2010) som är kritisk till konsensusidealet och hävdar att det inte kan finnas pluralism utan konflikt och sällar sig 
till Mouffe (1999) som också ifrågasätter detta. Hon förespråkar ett agonistiskt pluralistiskt förhållningssätt och menar att om man vill lösa ett problem är det vitalt att det är konsensus om vad det är man vill lösa. Sedan måste man tillåta att det kan finnas konflikter och olika åsikter om hur man löser det aktuella problemet. Mouffe menar att kärnan i politik bör vara den diskursiva kampen för hegemoni där olika åsikter och tillvägagångssätt kontinuerligt ställs mot varandra. I denna kamp ser deltagarna på varandra som värdiga motståndare där de inte behöver övertygas utan där deras åsikter kan också vara legitima.

Öhman och Öhman (2012) berör även detta och diskuterar två motsatta perspektiv inom hållbarhetsundervisning i skolan, konflikt och harmoni. De menar att det ska finnas utrymme för båda perspektiven och att harmoniperspektivet kan vara till nytta som ett didaktiskt koncept. Inom detta kan eleverna arbeta med arbetsuppgifter kring hur en harmonisk relation mellan ekologisk, social och ekonomisk hållbarhet på olika sätt kan skapas i samhället. Men från ett demokratiskt perspektiv menar de att det även är viktigt för eleverna att uppleva de inneboende konflikter som finns inom begreppet hållbar utveckling. Det gäller att skapa utrymme i undervisningen för att ge eleverna normativa kunskaper kring hur vi kan hantera olika akuta miljömässiga och sociala problem i samhället, men även ge dem möjlighet att utveckla förmågor kring kritisk tänkande, att bilda egna åsikter samt acceptera andras åsikter. Hur lärare och elever positionerar sig i fråga om huruvida diskussionen handlar om att övertyga de andra för att nå konsensus eller inte har relationer till hur arbetet med undervisningen i stort läggs upp.

\section{Frågor på individnivå eller samhällsnivå}

Den elevuppgift som arbetades med inom Erasmus+ partnerskapet innehöll komplexa och kontroversiella frågor som var på en sociopolitisk nivå där de alternativa lösningarna i första hand gällde olika system, regleringar eller andra kollektiva lösningar på samhällsnivån. Frågorna placerades i en fiktiv miljö och detta ser Fiehn (2005) som en distansmetod att använda sig av i arbete med kontroversiella 
frågor. Denna metod kan underlätta diskussioner kring frågeställningar som är känslomässigt laddade för elever på individnivå eller om det finns andra starka föreställningar kring hur något ska vara. Samtidigt innebär metoden att det oundvikligen blir en viss distans. Detta belyser en spänning gällande autenticiteten i en reflexiv undervisning. Att använda sig av kontroversiella frågor i undervisningen genom metoden SNI handlar om att skapa en mer autentisk undervisning (Sadler \& Zeidler, 2009).

Genom att utgå ifrån verkliga samhällsdilemman kan detta skapa relevans och intresse hos eleverna, men det är dock inte säkert att det som läraren upplever som autencitet harmoniserar med elevernas föreställningar. Eleverna ser inte alltid det läraren tycker är autentiskt som en väsentlig del av deras egen vardag (Åkerblom \& Lindahl, 2017). För att åstadkomma större upplevelser av autenticitet skulle en strategi vara att utgå ifrån frågeställningar som är aktuella och del av elevernas vardagliga medvetande. Det kan vara kontroversiella frågor där det finns aspekter på en mer personlig nivå och där frågan kan ha lösningar som beror på handlingar på individnivå. När frågorna ligger nära eleverna och där deras eget agerande direkt kan spela in finns stora förutsättningar för att undervisningen engagerar eleverna. Detta är en strategi annan än den som användes inom denna studie, där det var frågeställningar på samhällsnivå med lösningarna primärt på den politiska arenan. Dessutom var scenariot för arbetet att starta en ny civilisation på en fiktiv planet, vilket man knappast kan hävda vara vardagsnära, även om frågeställningarna som hanterades är detsamma som de vi $\mathrm{i}$ vårt samhälle måste hitta hållbara lösningar på.

Att utgå från frågor som ligger nära eleverna och deras vardag kan medföra ökat engagemang och är det frågor som berör eleverna är det fullt rimligt att man även diskuterar dem i skolan. Om frågan ligger för nära eleverna finns risk att de redan har bildat sig en uppfattning i frågan. Även om man i undervisningen ger exempel på alternativa synsätt kan det vara svårt för eleven att ta till sig av dessa. Är frågorna på en personlig nivå kan det även röra upp känslor och elever kan känna sig personligt utsatta om deras egna handlingar 
inte stämmer överens med det som andra i klassrummet förespråkar. När fokus på lösningar på våra samhällsproblem hamnar för mycket på individuella val och personliga handlingar kan det skapa skuldkänslor hos eleverna, vilka kan känna sig personligen ansvariga för att lösa komplexa samhällsproblem där en stor del av lösningen egentligen ligger på politisk nivå (Ideland \& Malmberg, 2015).

I undervisning utifrån samhällsdilemmana på en strukturell och sociopolitisk nivå blir även den etiska dimensionen i diskussionerna annorlunda jämfört med om man arbetar med kontroversiella frågeställningar på det personliga planet. Lindvall (2016) refererar till Webers (2008) begrepp ansvarsetik som innebär att politiska diskussioner kräver sin egen form av moral där det kan hända att man måste välja mellan två onda ting men då ta ansvar för detta. Denna form av politisk moral ställer Weber mot sinnelagsetik vilken innebär att man följer absoluta moraliska principer. Lindvall (2016) menar att man ska vara försiktig med att se politiska beslut som ett val mellan det absolut goda och det absolut onda. Det som är det unika med politik är att det är denna som styr staten och ska se till allas bästa. Lindvall menar att det inom politiken också finns etik och moral, men ibland måste denna vara en annan än den som finns på ett mer personligt plan. Att hantera spänningen mellan dessa två former av etik är en utmaning i klassrummet när man diskuterar samhällsdilemman. Läraren vill beröra eleverna personligen och det ligger då nära till hands att eleverna använder sig av sinnelagsetik. Samtidigt strävar undervisningen mot att eleverna ska använda sig av ansvarsetik i diskussionerna kring samhällsdilemmana.

När man planerar en undervisning om kontroversiella frågor och ska göra ett urval av frågeställningar framskymtar ett didaktiskt dilemma kring hur autentisk och nära elevernas vardag frågan ska vara. Är den vardagsnära och innebär att personliga handlingar kan ses som en del av lösningen är den troligen engagerande för eleverna, men samtidigt kan diskussioner väcka starka och oönskade känslor. Närheten till ämnet kan dessutom göra att eleverna kan ha svårt att se objektivt och rationellt på olika aspekter och möjliga handlings- 
alternativ. Om frågorna är på helt en strukturell samhällsnivå minimeras riskerna för detta men samtligt kan relevansen för eleverna bli liten och deras engagemang för undervisningen därigenom mindre. 


\section{SLUTDISKUSSION}

I detta kapitel diskuterar jag studiens resultat i förhållande till mina teoretiska utgångspunkter. Jag relaterar även resultaten om de didaktiska dilemman som studiens lärare upplevde till att förändra undervisningspraktiker i stort. När lärarna i studien arbetade med en delvis ny sorts undervisning behövde de upptäcka förgivettagna didaktiska positioner och hantera undervisningens syfteskomplexitet och detta kan vara giltigt även när lärare utvecklar sin undervisning på andra vis.

\section{Spänningar och didaktiska dilemman}

Att bedriva undervisning är en komplex aktivitet där snabba beslut ofta måste fattas i olika unika situationer som uppstår i klassrumsvardagen. Ett sätt att se på undervisningen är att se den som ett komplext verksamhetssystem inom vilket lärare och elever utför en rad synliga och målinriktade handlingar. Dessa handlingar är i sin tur påverkade av sociala strukturer och kopplade till regler, lagar och normer kring undervisningen. Handlingarna påverkas av den gemenskap som finns mellan personer som har intresse av undervisningen och även av den arbetsfördelning som gäller på skolan (Engeström, 1987). Såväl mellan delarna i systemet som mellan verksamhetssystemet och närliggande verksamheter uppstår strukturella spänningar som ackumuleras över tid (Engeström \& Rückriem, 2005). Genom att uppmärksamma dessa motsättningar finns möjligheter till utveckling av undervisningen. Ett delvis överlappande synsätt är att betrakta undervisningen som ett dilemmatic space, vilket är ett komplext och föränderligt system med olika aktörer och med olika positioner där lärare ständigt ställs inför didaktiska dilemman (Honig, 1994; Fransson \& Grannäs, 2013). I undervisningens dilemmatic space intar läraren hela tiden olika positioner utifrån erfarenheter, gällande regler och normer och det omgivande sociala sammanhanget. Detta skapar ett "space" av dilemman där normer, 
värderingar, handlingsalternativ, beslut och roller positioneras i relation till varandra och läraren intar positioner mer eller mindre omedvetet.

För att hantera klassrumsundervisningens komplexitet och de snabba beslut som måste fattas tar läraren en del saker för givna. Det finns helt enkelt inte tid att göra noggranna överväganden kring alla de didaktiska val som ska fattas under en lektion. Utifrån teorier från grundutbildning och fortbildning, läroplanen, läromedel, kollegiala normer samt erfarenheter från tidigare undervisning gör läraren ett urval av delar vilket sedan betraktas som förgivettaget i undervisningen (Almqvist, 2014). På samma gång som läraren tar saker för givna för att hantera klassrumsundervisningen i stunden, måste det även finnas en medvetenhet om att man gör förgivettagna didaktiska val. Det som är förgivettaget är av sin natur svårt att upptäcka och Almqvist poängterar att läraren behöver synliggöra och problematisera det som valts ut och tagits för givet i undervisningen. Detta är inte minst viktigt när undervisningen på olika vis förändras och förgivettagna positioner inte längre blir helt giltiga. Detta var fallet för studiens lärare när de bedrev en reflexiv undervisning som i flera avseenden skiljde sig från den gängse undervisningen. Rolf (2006) menar att teori och praktik är oskiljaktiga och att det inte finns endast en given lösningsmodell som passar i alla de olika situationer som uppstår i undervisningens komplexitet. Istället behöver lärarna gemensamt bygga upp en repertoar av olika procedurer och tillvägagångssätt att välja bland. Med hjälp av didaktiska modeller som betraktar val i undervisningen som didaktiska dilemman kan lärarna gemensamt synliggöra och reflektera över sina förgivettagna positioner, diskutera olika handlingsalternativ och därmed förfina sina procedurer.

Under studiens första fas identifierades arton olika spänningar som upplevdes av lärare när de arbetade med en reflexiv undervisning. Under fokusgruppsdiskussionerna framkom det att lärarna inte upplevde alla spänningar helt på samma vis och spänningarna kunde ta sig uttryck på olika vis i undervisningspraktiken. Resultaten visar på att lärarens agerande i denna form av undervisning påverkas av olika 
delar i undervisningens verksamhetssystem. Det finns motsättningar i verksamhetssystemets djupa sociala strukturer i form av regler, gemenskap och arbetsfördelning som man behöver hantera i en förändrad praktik (Engeström, 1987). De identifierade spänningarna tematiserades utifrån var motsättningens tyngdpunkt låg. Det var spänningar kopplade till

- läroplan, nationella prov och bedömning

- rådande religiösa värderingar och politiska åsikter i samhället

- lärares ämnesövergripande samarbeten

- själva genomförandet av klassrumsundervisningen.

Resultaten pekar på den inneboende komplexitet som finns i en ämnesövergripande undervisning som tar sin utgångspunkt $i$ kontroversiella samhällsdilemman. Som lärare måste man hantera motstridiga direktiv, förväntningar och uppgifter i en undervisning med flera syften där läraren själv måste bestämma vilket syfte som är viktigast $\mathrm{i}$ den aktuella undervisningen. De motstridiga uppdragen läraren har att hantera kommer i sin tur från olika nivåer i skolsystemet, men även från intressenter i det omgivande närsamhället. Djupgående sociala strukturer beträffande uttolkning av läroplan, betygssättning, nationella prov, schema, undervisningsmetoder, klassrumsrutiner, föräldrapåverkan och traditioner i samhället skapar en tröghet i förändring av undervisningspraktiker (Engeström, 2008). Studien visar att denna tröghet finns på alla studiens fem skolor men skiljer sig åt mellan dem.

I studiens andra fas beskrevs fyra didaktiska metadilemman inom vilka de svenska lärarna upplevde att de ställdes inför didaktiska val där det inte fanns ett handlingsalternativ som var fullständigt tillfredsställande. Dessa dilemman gällde

- elevcentrerade eller lärarcentrerade arbetsformer

- undervisning mot bildningsmål eller utbildningsmål

- om läraren ska vara objektiv, neutral eller ta ställning

- om anpassningar vid muntliga diskussioner ska göras eller inte. 
I de konkreta didaktiska dilemmana intog lärarna som regel en förgivettagen position som sedan synliggjordes i en didaktisk komparation med övriga lärares didaktiska val i denna studie. Man får anta att de positioner som de svenska lärarna intog gjordes med elevernas bästa för ögonen. Samtidigt finns en del potentiella konsekvenser med dessa didaktiska val. Hur de svenska lärarna positionerade sig i de olika didaktiska dilemmana var som regel inte heller något de själva analyserade och reflekterade över i varje given situation. Flertalet didaktiska val gjordes istället efter en förgivettagen procedur som grundats i den nationella undervisningstraditionen, skolans kultur och i lärarens egna erfarenheter.

\section{Undervisningens komplexitet}

Den intentionellt reflexiva undervisningen inom studien var en undervisning som skulle skapa utrymme att arbeta med såväl kvalificering, socialisering som subjektifiering. Alltså var intentionen att inkludera alla de tre funktionerna, eller övergripande syftena, för utbildning (Biesta, 2009). Det betydde att undervisningsaktiviteterna i studien därmed troligen betonade fler syften än en traditionell lektion och i så fall kan undervisningen inom studien ses som ännu mer multimotivdriven (Alnervik, 2013) än i vanliga fall. I den reflexiva undervisningen finns en uppenbar syfteskomplexitet (Frelin, 2013), där Biestas tre huvudsyften ska hanteras. Biesta (2015) skriver att huvudsyftena ibland står i konflikt med varandra och en avgörande förutsättning för en god undervisning är lärarens förmåga att göra avvägningar mellan dessa olika syften. Läraren behöver i planeringen och utförandet av undervisningen göra medvetna avvägningar mellan syftena och även tona ner något syfte periodvis.

Muntliga diskussioner, kritiskt tänkande och argumentation hade en central plats i studiens reflexiva undervisning och subjektifieringssyftet betonades genom att det skulle finnas utrymmen för elevers egna ställningstaganden. Eleverna skulle ges möjlighet att relatera sig till, eller skilja sig från, den sociala ordningen och för att detta ska vara möjligt behöver undervisningen även betona socialiseringsoch kvalificeringsfunktionerna. Det räcker inte att man bara låter eleverna ta ställning i olika frågor i undervisningen, utan de måste 
även ha stöttning i form av kunskaper om samhällsdilemmats ämnesinnehåll, kunskaper om vetenskapens karaktär och kunskaper om rådande normer i samhället. Dessutom behövs grundläggande förmågor kring kritiskt tänkande. Det är en balansgång för läraren och om det läggs för mycket fokus på kvalificering genom att utveckla argumentationsförmågor eller på att överföra rådande sociala normer kan detta inverka på utrymmet eleven har för att bilda en egen uppfattning. När man bedriver en undervisning där Biestas tre funktioner ska vävas samman visar även Hasslöf (2015) att det är svårt för lärarna att hålla isär dessa olika syften. Detta kan i sin tur skapa spänningar mellan de tre olika huvudsyftena och funktionerna med utbildning.

Eleverna på studiens deltagande skolor arbetade med komplexa och kontroversiella samhällsfrågor utan givna svar där både epistemologiska argument och värdeargument gavs utrymme. I undervisningen behandlades även en del kunskapsinnehåll som inte alltid ingick i kursplanernas centrala innehåll och i den ämnesövergripande undervisningen berördes därför ibland ämnen där läraren var en lekman. I den konkreta undervisningen fanns en medelskomplexitet, där läraren behövde göra flera didaktiska val vilkas konsekvenser inte alltid kunde överblickas, men även en innehållskomplexitet, där olika delar av undervisningen inte alltid samverkade med varandra (Frelin, 2013).

När undervisningens syfte och motiv förändras ändras också verksamhetssystemets struktur och positioner i undervisningens dilemmatic space. Holmqvist och Olander (2017) förenar verksamhetens tre olika beståndsdelar: verksamhet, handling och operation (Leontiev, 1978) och didaktikens grundfrågor och pekar på att det ska finnas ett dynamiskt förhållande mellan delarna. Man kan sammanfattningsvis konstatera att i studiens undervisning var detta förhållandet mellan de tre beståndsdelarna inte särskilt dynamiskt. Anledningen till detta är att lärarna i liten utsträckning reflekterade över motiven för undervisningen och sällan eller aldrig egentligen ställde sig Varför-frågan under den reflexiva undervisningen. Detsamma får delvis även sägas om mig själv när jag förberedde lärarnas arbete 
genom att sätta samman en undervisningsmodell. Det visade sig att jag själv i detta arbete tog en del saker för givna. För lärarna inom denna studie var innehållet för deras arbete till viss del styrt genom undervisningsmodellen, men det fanns ändå en stor valfrihet kring hur de la upp sina läraktiviteter och hur de sedan agerade i den konkreta klassrumsundervisningen.

Lärarnas undervisning under temadagarna var på alla skolor väl genomförd och med elevernas bästa för ögonen. Utmaningen är att det i den multimotivdrivna reflexiva undervisningen finns flera syften och om inte lärarnas handlingar och operationer i undervisningen är relaterade mot medvetna syften, riskerar de didaktiska valen få oönskade konsekvenser i förhållande till andra syften. Som lärare behöver man därför vara uppmärksam på att undervisningen man ska bedriva kan ha olika syften och vara medveten om att handlingar och operationer i undervisningen kan behövas utföras på olika vis, beroende på vilket syfte som är prioriterat. En handling som utförs med relevant intention i förhållande till ett syfte kan ibland negativt påverka ett annat syfte. När handlingar relaterade till olika syften blandas i undervisningen kan dessa motverka varandra.

I den spänning som finns mellan olika syften uppstår didaktiska dilemman där läraren behöver vara medveten om både de didaktiska handlingsalternativens potentiella möjligheter och deras konsekvenser. En förutsättning för detta är att det skapas utrymme att diskutera Varför-frågor och att hitta en balans mellan olika syften i olika former av undervisningen. Hoppar man över denna motivdel i en verksamhets systematiska sammanhang (Leontiev, 1978) kommer undervisning att reduceras till att bestå av olika målrelaterade handlingar utan inbördes relation. Risken är att undervisningen kommer att styras av frågor kring innehåll och läraktiviteter. Den praktiska undervisningen kommer då att byggas upp av en rad förgivettagna operationer, vilka inte alltid står i ett systematiskt förhållande till det som undervisningen primärt skulle syfta till. Har läraren inte motiv och syften för sin undervisning klara för sig kan de didaktiska valen i den dagliga undervisningen komma att motverka varandra. 


\section{Förgivettagna didaktiska positioner}

Denna studie visar att man som lärare har en hel del förgivettagna positioner i sin undervisningspraktik. Dessa är nödvändiga för att man ska kunna hantera klassrummets komplexa vardag, men speciellt när man utvecklar och förändrar sin undervisning är det också viktigt att bli medveten om de förgivettagna positioner man har i undervisningen och hur de relaterar till varandra. Detta illustreras i denna slutdiskussion genom att utgå ifrån ett av studiens identifierade metadilemman, rörande elevcentrerade eller lärarcentrerade arbetsformer i den reflexiva undervisningen, och belysa hur positioner i detta dilemma relaterar till positioner andra didaktiska dilemman.

De svenska lärarna gjorde under temadagen det didaktiska valet att låta eleverna ansvara för mycket av faktainhämtningen. Detta grundade sig i att förmågor att söka och granska information är starkt framskrivna i svenska läroplanen. Detta är förmågor som kan leda till att eleverna utvecklar en mer övergripande förmåga att tänka kritiskt och grunden till de svenska lärarnas didaktiska val var en intention att eleverna skulle utveckla just detta. Detta är helt i linje med utbildningssyftet att kvalificera eleverna för framtida utmaningar genom att träna deras förmågor kring kritiskt tänkande. Hasslöf (2015) visar att förmågor rörande kritiskt tänkande berör fler syften och det kan även betraktas som en socialisering in i ett vetenskapligt förhållningssätt och som en avgörande del i subjektifiering.

En lärare kan sätta subjektifieringssyftet i förgrunden och därför vilja skapa en undervisningsaktivitet som ger möjligheter för eleverna att ta egen ställning i en kontroversiell fråga. Om läraren parallellt gör oreflekterade didaktiska val riktade mot andra syften kan effekterna av dessa val motverka det ursprungliga huvudsyftet. De svenska lärarnas förgivettagna positioner gällande elevcentrerade och lärarcentrerade arbetsformer innebar att eleverna gavs stort ansvar både i informationsinhämtning och i gruppdiskussioner. Att det blev denna position kunde kopplas till fokus på dessa förmågor i 
kunskapskraven, en intention att alla elever skulle få taltid i diskussioner, en diskurs som förordar elevaktiva arbetssätt med eget ansvar och grupparbete samt en aktuell satsning för ökad IKT-användning.

De svenska lärarna gjorde dessa didaktiska val kring arbetsformen med intentionen att träna förmågor som på sikt utvecklar elevernas kritiska tänkande. Om lärarna positionerar sig extremt och lägger över för stort ansvar på eleverna att själva vara aktiva informationssökare hamnar kvalificeringsfunktionen av kritiskt tänkande i förgrunden. Eleverna får träning i att söka och granska information och får stort utrymme att uttrycka sina åsikter i gruppdiskussionerna och utvecklar dessa förmågor. När eleverna gör detta under alltför stort eget ansvar är risken samtidigt stor att deras kunskaper om samhällsdilemmat förblir grunda och att diskussionerna blir varvade monologer om egna erfarenheter, snarare än intellektuella tankeutbyten. Givetvis ger en stark elevaktiv undervisning utrymme för att eleverna tar egen ställning både genom att man själv kan hitta sina argument och genom att man ges stort utrymme att testa sina argument i diskussionerna. Ska man ta ställning kring ett riktigt samhällsdilemma och förhålla sig till detta, och eventuellt kunna ifrågasätta gällande normer och uppfattningar, behöver man emellertid ha en kunskapsgrund att stå på. Denna måste innehålla uppfattningar kring olika vetenskapliga perspektiv, sociala, miljömässiga och ekonomiska aspekter samt etiska och filosofiska synsätt kring dilemmat. Beroende på elevernas ålder, kunskaper och mognad behövs lärarguidning i olika stor omfattning för att få denna grund.

\section{Lärarens beslutsfattande $\mathrm{i}$ en reflexiv undervisning}

Förutom att behovet av att ifrågasätta förgivettaganden i sin egen praktik är det avgörande att man som lärare kontinuerligt ställer sig den didaktiska Varför-frågan kring sina undervisningsaktiviteter, inte minst i en praktik i förändring. Biesta (2015) påpekar att lärarens olika former av beslutsfattande är oerhört viktiga för en undervisning mot alla huvudsyften med utbildning. Diskussioner om detta beslutsfattande, och de dilemman som finns, är emellertid något som är alltför sällsynt lärare emellan (Biesta, 2009). Lärarens beslutsfattande kan beskrivas ske i tre steg (Biesta, 2015) där det först handlar 
om att klargöra både för sig själv och andra vilket eller vilka syften den aktuella undervisningen har utifrån de tre huvudsyftena för utbildning: kvalificering, socialisation och subjektifiering. Det gäller även i detta steg att analysera hur dessa syften kan stå i konflikt med varandra. Det andra steget i lärarens beslutsfattande handlar om att hitta en balans mellan syftena och att eventuellt tona ner något syfte periodvis om dessa står i konflikt med varandra. Det tredje steget i beslutsprocessen är att planera och genomföra undervisningen genom att göra didaktiska val i de konkreta didaktiska dilemmana i klassrumsvardagen. Detta avslutande avsnitt i slutdiskussionen är inspirerat av Biestas tre steg.

\section{Steg 1 - identifiera syfteskonflikter mellan positioner}

När den svenska positionen beträffande arbetsformen jämförs med den undervisning som bedrevs på de andra skolorna var den på de andra skolorna mer lärarstyrd. Vid en första anblick kan man tolka det som att den undervisningen därmed gav mindre utrymme för subjektifiering. Eftersom lärarna i större uträckning undervisade efter förmedlande metoder hamnade mer fokus på kvalificering av kunskaper i ämnet genom att läraren belyste olika aspekter av samhällsdilemmat. Eleverna gavs mindre träning i att själva söka information och eftersom det var läraren som i större utsträckning gjorde urval av information fanns även utrymme för läraren att socialisera eleverna och ibland kunde man höra lärarnas argument genom eleverna. Diskussionerna skedde huvudsakligen i helklass vilket möjligtvis begränsade möjligheterna för alla elever att få utrymme att ta egen ställning och testa denna. Sett ur dessa perspektiv hamnade kvalificering och socialisering mer i förgrunden under dessa temadagsaktiviteter. Eleverna på de utländska skolorna hade genom mer lärarcentrerade arbetsformer fått en större överblick kring det aktuella samhällsdilemmat än de svenska eleverna, både vad gäller kunskapsargument och mer värderelaterade aspekter. Samtidigt kan denna arbetsform begränsa elevernas egna ställningstaganden om lärarens roll blir alltför styrande. För att eleverna ska kunna bli politiska subjekt på allvar och bli ansvarsfulla och medkännande medborgare krävs en kunskapsgrund, men även utrymme i undervisningen att kunna ta egen ställning. 
Om undervisningen inte i tillräcklig grad ger eleverna kunskaper om det aktuella samhällsdilemmat begränsas elevernas möjlighet att göra egna ställningstaganden. De svenska elevernas ställningstaganden blev inte så välgrundade som de skulle kunnat vara, utan undervisningen blev mer som en träning $i$ att ta ställning för att förberedas för framtida ställningstaganden. I en undervisning med flera syften kan en handling som till synes är inriktad mot syftet få en annan effekt. De svenska lärarnas implicita tanke med sitt fokus på att utveckla förmågor kring kritiskt tänkande var att detta skulle skapa förutsättningar och utrymme för att eleverna skulle kunna ta egen ställning, inriktat mot subjektifieringssyftet. Undervisningen följde emellertid i stor utsträckning epistemologiprincipen och hur eleverna argumenterade och resonerade hamnade i förgrunden medan samhällsdilemmat i sig hamnade i bakgrunden. Undervisningen kom i praktiken att mer rikta in sig mot kvalificeringssyftet och om att förbereda eleverna för framtida ställningstaganden. Handlingar riktade mot ett syfte kan vidare vara en förutsättning för att andra syften ska kunna uppfyllas. En viss undervisning inriktad mot kvalificering i form av fördjupade kunskaper kring samhällsdilemmat i sig behövs för att eleverna ska få utrymme för subjektifiering och på säker grund kunna ta en egen ställning i frågan.

Syfteskomplexiteten och betydelsen av att relatera didaktiska val till olika syften belystes även i metadilemmat kring i vilken utsträckning läraren ska ta ställning eller ej. I diskussionerna under studiens temadag intog de svenska lärarna en neutral hållning och detta gjordes med en tydlig dynamik mellan undervisningsverksamhetens syfte och de handlingar och didaktiska val som gjordes. För att tona ner socialiseringsfunktionen och inte påverka elevernas egna ställningstaganden valde lärarna att inte dela med sig av sina egna åsikter. Denna neutralitet hade visserligen relationer till andra positioner lärarna intog, men oaktat detta kan läraren i sin roll påverka eleverna. Det är en relevant risk som potentiellt kan begränsa elevernas möjligheter till subjektifiering. Även om det verkade vara ett förgivettaget val bland de svenska lärarna bör man inte alltid ta för givet att en neutral hållning är den man ska inta som lärare. Att hålla sig helt 
neutral i alla frågor är en utmaning för läraren och är det frågor där läraren egentligen har en starkare övertygelse kan denna lysa igenom ändå. Om läraren utger sig för att vara neutral men ändå ger signaler om en åsikt kan dessa dubbla signaler komma att hämma elevernas egen åsiktsbildning jämfört med om läraren är öppen med sina åsikter och eleverna då vet vad de ska förhålla sig till.

Socialiseringsfunktionen är också viktig för utbildningen och skolan har en viktig uppgift i att överföra samhällets rådande normer och värderingar till den enskilde eleven. Om läraren tar neutralitetspositionen alltför långt och även övertolkar yttrandefriheten kan det ge extrema och kränkande åsikter spelrum. I speglingen gentemot hur lärarna förhöll sig på de andra skolorna var de svenska lärarnas neutrala hållning avvikande. Även om lärarna på de övriga skolorna inte alltid ventilerade sina egna åsikter i diskussionerna, ansågs det inte som något konstigt om läraren tog ställning. Det var istället något som sågs vara en del i utvecklingen för eleverna att lära sig att bemöta andras åsikter. Det krävs att eleverna känner att de verkligen kan säga emot sin lärare utan att det får konsekvenser och i sådana situationer är det avgörande hur eleven känner och inte läraren. I en del diskussioner på temadagarna där lärare öppet tog egen ställning visade det sig också att läraren har en stor inverkan på eleverna. Lärarens argumentation fick elevopinionen att svänga i frågan. Dessa frågor berörde exempelvis värdegrund och allas lika värde där lärarens egna ställningstaganden var i linje med detta och i sådana situationer krävs en balansgång för läraren mellan subjektifieringsfunktionen och socialiseringsfunktionen som inte är helt enkel att bemästra.

De svenska lärarna intog en neutral position och avslöjade inte sin egen ståndpunkt och beskrev att de med detta inte ville påverka elevernas egna ställningstaganden. Samtidigt uttryckte de åsikter genom att ofta inta en position som djävulens advokat under diskussionerna. Lärarna gjorde detta för att de ville utmana eleverna i diskussionerna för att träna och utveckla deras förmågor som ligger till grund för kritiskt tänkande. Detta är en förutsättning för att kunna 
fatta egna beslut som är underbyggda och på så sätt kan man betrakta de svenska lärarnas val av denna svaga objektivitet som ett sätt att kvalificera eleverna för en framtida subjektifiering. Vad gäller det aktuella samhällsdilemmat i den aktuella undervisningssituationen fick lärarens val att inta motsatt åsikt till elevernas till följd att innehållet och samhällsfrågan hamnade i bakgrunden. Detta gjorde att syftet med den reflexiva undervisningen primärt blev att träna olika förmågor för kritiskt tänkande. Detta inverkar på syftet att ge alla möjlighet till subjektifiering, åtminstone vid den aktuella undervisningsaktiviteten.

I den reflexiva undervisningen påverkas lärarna även av positioneringar och syften i närliggande verksamheter. Det kan vara syften och motiv som finns inom skolan och utbildningen som helhet, men som ligger utanför den konkreta reflexiva undervisningens verksamhet, vilket belystes i det tredje metadilemmat kring anpassningar i den reflexiva undervisningen. I samband med fokusgruppsintervjuerna diskuterades vid flera tillfällen de tystare eleverna i klassrummen och hur läraren skulle förhålla sig till dessa med tanke på att muntliga diskussioner utgjorde en väsentlig del av undervisningen. För dessa elever innebar deltagande i muntliga diskussioner en obekväm känsla och en omtanke om hur dessa elever påverkades är en fullt förståelig reaktion hos läraren. Ett möjligt didaktiskt val av läraren i detta didaktiska dilemma är att göra en anpassning av undervisning för eleven och låta denne slippa att deltaga i dessa muntliga diskussioner. Denna anpassning som grundas i lärarens omsorgsansvar kan emellertid komma i konflikt med syftet att just utveckla elevens viktiga förmåga att uttrycka sig muntligt. Erbjuds inte en elev tillfällen att träna förmågan är det givetvis svårt att utveckla förmågan. Det skapar ett dilemma för läraren att hantera något som på längre sikt kan göra eleven gott, men som på kort sikt kan medföra obehag och oro hos eleven.

Studiens fjärde metadilemma belyste den spänning som finns mellan utbildningsmål och bildningsmål i läroplanen och där mycket fokus hamnar på utbildningsmålen. Bedömning mot kunskapskraven var inte något som lyftes fram i undervisningsmodellen under studien 
men detta var ändå något som de svenska lärarna ständigt återkom till. Lärarna upplevde att de hade krav på sig att hela tiden likvärdigt och rättssäkert bedöma eleverna mot undervisningsmålen. De svenska lärarna diskuterade utifrån detta att göra anpassningar för elever som inte tog plats muntligt. De motiverade en sådan anpassning med att läraren har i uppgift att bedöma elevernas förmågor för en framtida betygssättning. Med utgångspunkt från de utmaningar som finns med att bedöma eleverna i muntliga diskussioner beskrev lärarna att de i liknande undervisning la in skriftliga moment. Med dessa kunde man likvärdigt och rättssäkert bedöma elevernas förmågor att resonera och argumentera istället för att göra det utifrån de muntliga diskussionerna. Enligt Hirsh (2017) diskuteras likvärdighet mestadels utifrån ett bedömningsperspektiv och betydligt mer sällan diskuteras hur själva undervisningen ska organiseras likvärdigt eller rättvist. Hon menar att likvärdighet inte bara kan ses ur ett bedömningsperspektiv utan något som måste finnas med redan från början i planeringen av undervisningen.

För de svenska lärarna hamnade mycket fokus på att utveckla elevernas olika förmågor för att bedöma dessa efter de tecken på dessa förmågor som uttrycks i kursplanernas kunskapskrav. Om syftet att utvärdera elevernas kunskaper mot kunskapskraven ges för stort utrymme kan didaktiska val och handlingar relaterade till detta komma i konflikt med syften som att arbeta med läroplanens demokratimål eller bildningsmål att långsiktigt utveckla olika förmågor hos eleverna. Detta belyser den spänning mellan utbildningsmål och bildningsmål som finns i läroplanen (Carlgren, 2015) där en pseudoformativ bedömning av elever riskerar växa fram (Jönsson, 2016). I denna undervisning är det utbildningsmål och avprickning av elevresultat mot kunskapskrav som styr planeringen av undervisningen, istället för bildningsmålen i form av förmågorna.

\section{Steg 2 - balansering och prioritering av olika syften}

Är man som lärare inte är fullt medveten om undervisningens syfteskomplexitet och inte är uppmärksam på didaktiska val och förgivettagna positioner i sin undervisning, kan handlingar man tror sig göra riktade mot ett syfte i själva verket nästan vara kontraproduktiva. 
Att balansera utbildningens olika funktioner och veta vilken man ska betona mest $\mathrm{i}$ en bestämd undervisningssekvens är en utmaning. Att erbjuda eleverna mycket träning i förmågor för kritiskt tänkande ger förutsättningar för subjektifiering, men utan kvalificering i form av relevanta kunskaper kring samhällsdilemmat samt socialisering om rådande synsätt blir subjektifieringen ofullständig. Samtidigt behöver eleverna tränas i de förmågor som är förutsättningar för ett kritiskt tänkande och för att kunna ta egen ställning. Läggs alltför mycket fokus på kvalificering av ämneskunskaper eller om läraren betonar socialiseringsfunktionen i alltför stor grad kan detta begränsa möjligheten för elevernas egna ställningstaganden. Läggs alltför mycket fokus på träning och utvärdering av elevernas förmågor hamnar själva frågan i samhällsdilemmat i bakgrunden och möjligheten till subjektifiering begränsas.

Är man uppmärksammad på undervisningens olika syften, och reflekterat över hur de relaterar till varandra, kan man mer effektivt göra goda didaktiska val i sin undervisningspraktik. Man kan även se förgivettagna didaktiska val och de didaktiska dilemman som oundvikligen finns och genom detta förändra och förbättra sin undervisning. Såväl när läraren planerar sin undervisning som när den undervisar konkret i klassrummen, måste läraren hitta en balans mellan olika syften och när det behövs kunna prioritera mellan olika syften. I vilken mån det går att kombinera och balansera olika syften eller hur läraren ska prioritera mellan syften finns det inte någon given lösningsmodell för. Dessa didaktiska val måste ständigt omprövas beroende på aktuell situation. Med en repertoar av olika tillvägagångssätt, med medvetenhet om olika syften och uppmärksamhet på de didaktiska dilemman som finns kan läraren göra dessa didaktiska val mer välgrundat.

Har eleverna i tidigare undervisning fått möjlighet att utveckla förmågor för kritiskt tänkande behöver undervisningen också ge eleverna tillfälle att subjektifieras och få chans att ta egen ställning och pröva denna mot andras åsikter. När man gör detta är det viktigt att det blir en balans mellan olika syften i undervisningen och säker- 
ställa att eleverna får stöd med att få den information kring samhällsdilemmat som behövs för att bilda sig en välgrundad åsikt. Läraren behöver göra didaktiska val kring vilken roll denne ska inta under elevdiskussionerna. Det finns olika strategier och läraren behöver vara medveten om deras möjligheter och begränsningar. Det kan vara så att läraren använder ett samhällsdilemma i undervisningen för att belysa viktiga begrepp i sitt ämnes centrala innehåll i en kallare form av SNI-undervisning (Simonneaux, 2014a). I detta fall är det utvecklandet av elevernas naturvetenskapliga kunskaper om ett fenomen som är lärarens främsta syfte och i så fall är det rimligt att man som lärare också intar andra positioneringar i de didaktiska dilemmana.

Är det så att läraren har som främsta syfte med en undervisningsaktivitet att arbeta mot bildningsmålen och skapa utrymme för subjektifiering bör denne överväga om man ska använda detta som underlag för att betygssätta eleverna. Att sätta betyg på eleverna är ett oundvikligt uppdrag lärare har, men att samla underlag för att sätta ämnesbetyg på elever när de uppmanas att uttrycka egna åsikter kring ämnesövergripande samhällsdilemman kan innebära en syfteskonflikt. Det kan bli så att eleverna fullt förståeligt fokuserar mer på betyget än på att bilda en egen åsikt och därmed kommer utbildningsmålen att överskugga bildningsmålen.

När det gäller diskussioner kring aktuella samhällsdilemman blir eleverna engagerade och denna inre motivation blir en motor i lärandet som kan störas av yttre motivation. Samtidigt har man som lärare ett myndighetsuppdrag att utvärdera och betygssätta elever och en reflexiv undervisning erbjuder möjligheter att utvärdera flera olika förmågor. Är det primära syftet med undervisningsaktiviteten att skaffa underlag för bedömning måste läraren omvärdera sin positionering i de didaktiska dilemmana i linje med detta syfte. För elever som ogärna tar plats i muntliga diskussioner måste deras muntliga deltagande balanseras så att de kan få chans att subjektifieras utan att de mår dåligt. För dessa elever är det extra viktigt att de får möjlighet till strukturerad träning för att på sikt utveckla förmågan 
och efter hand kunna ta större plats i muntliga diskussioner vilket är ett viktigt bildningsmål.

Steg 3 - didaktiska val i en reflexiv undervisning

Som beskrivits ovan finns det inte en enda evidensbaserad arbetsmodell att följa när man ska genomföra en undervisning med utgångspunkt från samhällsdilemman. De didaktiska dilemman som uppstår är beroende på det dilemmatic space där undervisningen ska genomföras och är helt kontextberoende. Genom kollegiala diskussioner lärare emellan kan lärarnas praktiska kunskaper stärkas och deras handlingsrepertoar utökas vilket underlättar beslutsfattandet. Det diskussions- och reflektionsverktyg som det lagts en grund för i denna studie ämnar stötta sådana diskussioner.

För de metadilemman som diskuterats i denna licentiatuppsats är det avgörande att läraren balanser syftena i undervisning mot varandra och i vissa fall väljer bort något syfte. Undervisningen ska riktas in mot de syften som anges i läroplan och kursplaner vilket innebär att bildningsmålen är de som ska styra planeringen av undervisningen. Som lärare måste man emellertid också utvärdera undervisningen gentemot fastlagda utbildningsmål i form av kunskapskrav. Med ökad förståelse för utbildningens olika syften blir det enklare för läraren att stå emot så att läraren inte positioneras alltför nära en undervisning som planeras endast efter utbildningsmålen. Läraren måste vidare fatta beslut och göra didaktiska val i undervisningen så att eleverna är aktiva och engagerande deltagare i en demokratisk beslutsprocess där läraren fungerar som en deltagande expert i praktiken. För oerfarna elever behöver läraren i undervisningen även inta en mer förmedlande roll och stötta eleverna med relevanta kunskaper och information kring samhällsdilemmana, för att de ska kunna ta ställning på säker grund. Vilken balans man har mellan dessa är beroende av elevgruppen och den kunskapsnivå och vilka förmågor kring kritiskt tänkande den besitter. Det beror också på om syftet är att förbereda eleverna för framtida ställningstaganden eller om man vill att de ska göra välgrundade ställningstaganden kring en aktuell fråga där och då. 
I metadilemmat kring anpassning gäller det att hitta en balans mellan syftena så att inte anpassningar innebär att tysta elever förhindras möjligheten att utveckla sina muntliga förmågor i undervisningen. Läraren behöver samtidigt vara uppmärksam på det obehag eleven kan uppleva kring deltagande i muntliga diskussioner och att en svag muntlig prestation i sig inte betyder att elevens övriga förmågor kring kritiskt tänkande är svaga. I diskussionerna kan det finnas fördelar att både att vara objektiv och att vara neutral och de beslut som man som lärare tar beror på vilket syfte man har med undervisningsaktiviteten. Är man som lärare neutral men intar motsatt åsikt till elevernas kan man få diskussioner där eleverna utmanas och på så sätt utvecklar förmågor att argumentera, resonera och diskutera. Olika positioneringar i dessa didaktiska dilemman innebär att utbildningens huvudsyften kommer i konflikt med varandra och därför behöver lärare göra klart för sig vilket syfte den kommande undervisningssekvensen har och sedan fatta didaktiska beslut utifrån detta.

Att arbeta med en reflexiv undervisning innebär att man arbetar ämnesövergripande och lyfter upp skolans bildningsmål. I en högstadieskolas traditionella organisation är det ämnesuppdelade lektioner där eleverna har kortare arbetspass och byter lektionssal och lärare flera gånger under dagen efter ett schema som är likadant från första till sista dagen under läsåret. Detta är inte den optimala strukturen om man ska arbeta med att undersöka kontroversiella och komplexa samhällsdilemman. Eleverna behöver tid på sig att sätta sig in i frågornas komplexitet och inte tvingas bryta arbetet vid ett visst klockslag, exempelvis eftersom en annan klass är schemalagd i lokalen. Under arbetet med samhällsdilemmat är det gynnsamt för eleverna att de har lärare med olika ämneskompetenser tillgängliga, för att belysa frågan utifrån olika aspekter men även för att hjälpa till att utveckla förmågor kring att resonera sig fram till en ståndpunkt och effektivt lägga fram argument för denna. När det gäller diskussioner kring samhällsdilemman behöver det finnas utrymme för dessa att ta den tid de tar, och inte styras av förutbestämda rasttider eller andra strukturer i skolans arbetsfördelning. 
Att arbeta i längre arbetspass med få bestämda hålltider där flera lärare är tillgängliga för eleverna är en organisationsform av skolan som inte helt harmoniserar med undervisning i en schemastyrd skola av traditionellt snitt. Arbetsmodellen med ett schema som gäller över hela läsåret är givetvis en arbetsfördelning för att effektivt säkerställa att eleverna får den undervisningstid i de olika ämnena som de garanteras i timplanen och att lärarens arbetstid stämmer med gällande avtal. Att arbeta med längre arbetspass under vilka flera lärare finns tillgängliga beroende av elevernas aktuella behov kräver en välplanerad arbetsfördelning. Egna erfarenheter säger mig att många skolor som prövat att undervisa på detta ämnesövergripande vis tagit för lätt på att bygga upp dessa strukturer, vilket gjort att riskerna med en alltför fri arbetsorganisation visat sig. Det är ett organisatoriskt dilemma där denna frihet kan innebära att vissa lärare får bristande kontroll över elevers kunskapsutveckling, medan andra lärare överbelastats med arbetsuppgifter. En annan erfarenhet från denna studie är att lärare och skolledare ofta tror att man måste följa den ena eller den andra undervisningsorganisationen hela tiden och inte inser att det faktiskt går att kombinera en traditionell undervisning efter ett veckoschema med undervisningsaktiviteter som då och då under läsåret bryter schemat.

Genom att kollegialt analysera vilka olika funktioner utbildningen har och analysera olika syften både i undervisningen i stort och ämnesundervisningen mer specifikt, kan man fördela undervisningen mellan en traditionellt ämnesuppdelad undervisning och en ämnesövergripande undervisning med annat arbetsschema. Genom analys och reflektion kan man på skolan identifiera vilka delar av bildningsmål och utbildningsmål som lämpar sig bäst i respektive undervisningsform. Man skulle kunna tänka sig att eleverna arbetade med att kvalificera sig och träna upp förmågor för kritiskt tänkande i en mer ämnesuppdelad undervisning och i denna också få en kunskapsbas rörande samhällsdilemmat. I en mer ämnesövergripande undervisningsform kunde sedan dessa samhällsdilemman undersökas vidare och diskuteras på ett demokratiskt sätt där eleverna fick chans att testa egna åsikter och ta ställning. Helt avgörande för framgång 
är att den schemabrytande ämnesövergripande undervisningen betraktas som minst lika viktig som den ordinarie undervisningen och att minst lika mycket resurser läggs på att skapa en fungerade arbetsfördelning även för denna undervisningsform. Skolans uppgift är att förbereda eleverna för ett långt liv i en föränderlig värld och för att göra detta behöver också skolan och undervisningen vara föränderlig. Det betyder inte att allt med nödvändighet behöver förändras, men förgivettagna positioner behöver medvetandegöras och relateras till andra positioner i det dilemmatic space som skolan och undervisningen befinner sig i. Med en ökad medvetenhet kring de organisatoriska och didaktiska dilemman som finns kan undervisningen sakta men säkert förbättras och därmed även få en starkare resistens mot de yttre krafter som kan komma att påverka skolan i ett framtida reflexivt samhälle.

\section{Slutord}

Avsikten med denna licentiatuppsats var att belysa några avgörande didaktiska dilemman som lärare ställs inför när de engagerar sig i en intentionellt reflexiv undervisning. Studien visar att för att hantera dessa dilemman och för att framgångsrikt kunna förändra sin undervisning är det avgörande att man relaterar till de huvudsyften som finns med utbildning och även andra syften som finns i skolverksamheten. Man behöver kunna se hur de olika syftena hänger samman med de målstyrda handlingar man dagligen utför i sin undervisningspraktik. Därigenom kan man upptäcka att olika syften ibland kan hamna i konflikt med varandra och att olika handlingar i klassrumsvardagen kan komma att motverka varandra.

En lärare som undviker en mer öppen och elevaktiv undervisning kring kontroversiella frågor gör troligen inte detta för att den är fundamentalt övertygad om att en traditionell faktaförmedlande undervisning är det enda rätta. Snarare beror lärarens motstånd på en osäkerhet kring de utmaningar som oundvikligen uppstår i en förändrad undervisning. Det kan exempelvis gälla hur man ska hantera känsloladdade diskussioner, hur man hanterar sina personliga åsikter eller hur man ska göra med elever som känner obehag för moment i undervisningen. Förutom lärarens egen osäkerhet påverkas 
möjligheterna för förändring av undervisningspraktiker även av att man som lärare blir positionerad på olika vis i de didaktiska dilemmana av andra delar i undervisningens verksamhetssystem. Dessa utgörs av djupgående sociala strukturer i undervisningens komplexitet gällande betygssättning, nationella prov, schema, klassrumsrutiner, föräldrar och traditioner, vilka sammantaget skapar en förändringströghet i undervisningen.

För att förändra undervisning räcker det emellertid inte med att man som lärare har en förståelse av komplexiteten och utmaningar på en metanivå. För att man ska skapa en bestående förändring behöver man bearbeta vart och ett av de didaktiska dilemmana som finns i den önskade undervisningen. I denna process måste positioneringar i didaktiska dilemman kontinuerligt relateras till syftet med den aktuella undervisningen. Genom kollegiala diskussioner kan lärare få en förberedelse för utmaningarna som finns och även bygga upp en handlingsrepertoar att kunna ta till när man prövar nya undervisningsstrategier.

När lärare tillsammans kan se helheter i undervisningen samt förstå och kunna prioritera mellan olika syften kan utmaningarna lättare hanteras. Det behövs dock tid och möjlighet för lärare att resonera kring alla de små och instrumentella didaktiska dilemman som uppstår i skolvardagen och upptäcka förgivettagna positioner i dessa. Genom gemensam reflektion kan lärare bygga upp en handlingskompetens för att kunna hantera framtida didaktiska dilemman på lämpligt vis beroende på undervisningsaktivitetens syfte och dess kontext. Då kan läraren förändra och utveckla sin undervisning, om än i små steg. 


\section{REFERENSER}

Aikenhead, G. S. (2006). Science education for everyday life: Evidence-based practice. New York: Teachers College Press.

Amnå, E., Englund, T., Arensmeier, C., Ekman, J., Ljunggren, C., Unemar Öst, I., \& Zetterberg, P. (Red.). (2010). Skolor som politiska arenor: medborgarkompetens och kontrovershantering: internationella studier. Stockholm: Skolverket.

Almqvist, J. (2008). Artefaktanvändning i undervisningssammanhang: En privilegieringsanalys. Utbildning och demokrati, 173), 47-68.

Almqvist, J. (2014). Att synliggöra det förgivettagna. I B. Jakobson, I. Lundegård \& P. O. Wickman (Red.), Lärande i handling. Lund: Studentlitteratur.

Almqvist, J. (2015). Teaching traditions and learning in physical education and science education: A double symposium at ECER 2015. Presenterad vid ECER, 8-11 september, 2015 i Budapest, Ungern.

Almqvist, J. (2016). Didaktik och ämnesdidaktik: Exemplet Uppsala universitet. Hämtad 2018-01-17 från http://www.diva-portal.org/smash/get/diva2:901511/FULLTEXT01.pdf

Alnervik, K. (2013). "Men så kan man ju också tänka!": Pedagogisk dokumentation som förändringsverktyg i förskolan. (Doktorsavhandling). Jönköping: Högskolan för lärande och kommunikation.

Alvesson, M., \& Sköldberg, K. (2009). Reflexive methodology: New vistas for qualitative research. London: Sage.

Andrée, M., \& Lundegård, I. (2013). Scientific literacy som argumentation och kritik. I E. Lundqvist, R. Säljö \& L. Östman (Red.), Scientific literacy - eori och praktik. Malmö: Gleerups.

Arnqvist, A. (2010). Arbetsformer i grundskolan - från helklassundervisning till eget arbete. I S. Eklund (Red.), Forskning om undervisning och lärande - Utbildning på vetenskaplig grund. Stockholm: Lärarstiftelsen.

Beck, U., Giddens, A., \& Lash, S. (1994). Reflexive modernization: Politics, tradition and aesthetics in the modern social order. Redwood City: Stanford University Press.

Berthén, D. (2007). Förberedelse för särskildhet: Särskolans pedagogiska arbete $i$ ett verksamhetsteoretiskt perspektiv (Doktorsavhandling). Karlstad: Karlstads universitet. 
Biesta, G. (2009). Good Education in an Age of Measurement: On the Need to Reconnect with the Question of Purpose in Education. Educational Assessment, Evaluation and Accountability, 21, 33-46.

Biesta, G. (2011). God utbildning i mätningens tidevarv. Stockholm: Liber.

Biesta, G. (2012a). Becoming world-wise: an educational perspective on rhetorical curriculum. Journal of Curriculum Studies, 44, 815-826.

Biesta, G. (2012b). Have lifelong learning and emancipation still something to say to each other? Studies in the Education of Adults, 44, 5-20.

Biesta, G. (2015). What is education for? On good education, teacher judgement, and educational professionalism. European Journal of Education, 5O(1), 75-87.

Biesta, G., \& Osberg, D. C. (2010). Complexity, education, and politics: From the inside out and outside in. I D. Osberg \& G. Biesta (Red.), Complexity theory and the politics of education. Rotterdam: Sense

Billig, M. (red.) (1988). Ideological dilemmas: a social psychology of everyday thinking. London: Sage.

Birisci P., Metin M., \& Karakas M. (2010) Pre-service elementary teachers' views on concept cartoons: a sample from Turkey. Middle East Journal of Scientific Research, 5(2), 91-97.

Breiting, S., Hedegaard, K., Mogensen, F., Nielsen, K., \& Schnack, K. (2009). Action competence, conflicting interests and environmental education the MUVIN programme. Research Programme for Environmental and Health Education, DPU (Danish School of Education). Hämtad 2017-12-06 från http://www.dpu.dk/fileadmin/www.dpu.dk/en/research/researchprogrammes/environmentalandhealtheducation/forskning_miljoe-og-sundhedspaedagogik_20090707140335_action-competence-muvin.pdf.

Brunner, W. (1996). Solvagnen - visioner till din miljöundervisning. Stockholm: Liber.

Bronfenbrenner, U. (1992). Ecological systems theory. London: Jessica Kingsley Publishers.

Bränberg, A., \& Holmgren, U. (2015). Forskningsanknytning av grundutbildning: en praktisk analysmetod. I S. Pålsson och B. Victor (Red.), Proceedings från 5:e Utvecklingskonferensen för ingenjörsutbildningar. Uppsala: Uppsala universitet.

Bybee, R. W., Taylor, J. A., Gardner, A., Van Scotter, P., Powell, J. C., Westbrook, A., \& Landes, N. (2006). The BSCS SE instructional model: Origins and effectiveness. Colorado Springs: BSCS.

Caillot, M. (2007). The Building of a New Academic Field: the case of French didactiques. European Educational Research Journal, 6(2), 125-130. 
Carlgren, I. (2015). Kunskapskulturer och undervisningspraktiker. Göteborg: Daidalos.

Chaiklin, S., Hedegaard, M., \& Juul Jensen, U. (Red.), (1999). Activity theory and social practise: Cultural-historical approaches. Aarhus: Aarhus University Press

Chaiklin, S. (2007). Modular or integrated? -An activity perspective for designing and evaluating computer-based systems. International Journal of $\mathrm{Hu}^{-}$ man-Computer Interaction, 22(1-2), 173-190.

Chaiklin, S. (2013). Research knowledge production and educational activity. I V. Farnsworth \& Y. Solomon (Red), Reframing educational research: Resisting the 'What Works' agenda. Abingdon: Routledge.

Chang, S.-N., \& Chiu, M.-H. (2008). Lakatos' scientific research programmes as a framework for analysing informal argumentation about socio-scientific issues, International Journal of Science Education, 30(13), 1753-1773.

Chang Rundgren, S. N., \& Rundgren, C-J. (2010). SEE-SEP: From a separate to a holistic view of socioscientific issues. Asia-Pacific Forum On Science Learning \& Teaching, 11(1), 1-24.

Chen, X., Wei, G., \& Jiang, S. (2016). The ethical dimension of teacher practical knowledge: a narrative inquiry into Chinese teachers' thinking and actions in dilemmatic spaces. Journal of Curriculum Studies, 49(4), 1-24.

Crick, B. (2007). Citizenship: The political and the democratic. British journal of educational studies, 55(3), 235-248.

Crick, B. (1998). Education for Citizenship and the Teaching of Democracy in Schools: Final report of the advisory group on citizenship. London: Qualifications and Curriculum Authority.

Dewey, J. (1999, först publicerad 1916 på engelska). Demokrati och utbildning. Göteborg: Daidalos.

Dyke, M. (1997). Reflective learning as reflexive education in a risk society: empowerment and control? International Journal of Lifelong Education, 16(1), 2-17.

Dyke, M. (2009). An enabling framework for reflexive learning: Experiential learning and reflexivity in contemporary modernity. International Journal of Lifelong Education, 28(3), 289-310.

Eilks, I. (2015). Science education and education for sustainable developmentJustifications, models, practices and perspectives. Eurasia Journal of Mathematics, Science \& Technology Education, 11(1), 149-158.

Ekborg, M., Ideland, M., Lindahl, B., Malmberg, C., Ottander, C., \& Rosberg, M. (2012). Samhällsfrågor $i$ det naturvetenskapliga klassrummet. Malmö: Gleerups. 
Ekborg, M., Ottander, C., Silfver, E., \& Simon, S. (2013). Teachers' experience of working with socio-scientific issues: A large scale and in depth study. $R e-$ search in Science Education, 43(2), 599-617.

Engeström, Y. (1987). Learning by expanding. Helsingfors: Orienta-Konsultit Oy.

Engeström, Y. (1990). Verksamhetsteori och utvecklande arbetsforskning. Lycksele: Skytteanska.

Engeström, Y. (2001). Expansive learning at work: Toward an activity theoretical reconceptualization. Journal of education and work, 14(1), 133-156.

Engeström, Y. (2007). Enriching the theory of expansive learning: Lessons from journeys toward coconfiguration. Mind, Culture, and Activity, 14(1-2), 2339.

Engeström, Y. (2008). From teams to knots: Activity-theoretical studies of collaboration and learning at work. Cambridge: Cambridge University Press.

Engeström, Y. (2011). From design experiments to formative interventions. Theory \& Psychology, 21(5), 598-628.

Engeström, Y., \& Rückriem, G. (2005). Developmental work research: expanding activity theory in practice. Berlin: Lehmanns Media.

Engeström, Y., \& Sannino, A. (2010). Studies of expansive learning: Foundations, findings and future challenges. Educational Research Review, 5(1), 124.

Englund, T., Öhman, J., \& Östman, L. (2008). Deliberative communication for sustainability? A Habermas-inspired pluralistic approach. I S. Gough \& A. Stables (Red.), Sustainability and Security within Liberal Societies: Learning to Live with the Future. London: Routledge.

Erickson, F. (1998). Qualitative research methods for Science Education. I B. J. Fraser \& K. G. Tobin (Red.), International Handbook of Science Education Part 2. Dordrecht: Kluwer Academic Publishers.

Eriksson, M., \& Rundgren, C.-J. (2012). Vargfrågan - gymnasieelevers argumentation kring ett sociovetenskapligt dilemma. Nordic Studies in Science Education, 8(1), 43-58.

Eriksson, M. (2014). Att ta ställning: gymnasieelevers argumentation och beslutsfattande om sociovetenskapliga dilemman (Licentiatuppsats). Karlstad: Karlstads universitet.

Farahani, F. (2011). On being an insider and/or an outsider: A diasporic researcher's catch-22. I L. Naidoo (Red.), Education Without Borders: Diversity in a Cosmopolitan Society. Hauppauge: Nova Science Publishers Inc.

Fiehn, J. (2005). Agree to Disagree: Citizenship and controversial issues. London: Learning and Skills Development Agency. 
Flick, U. (2009). An introduction to qualitative research. London: Sage.

Fransson, G. (2012). Professionalisering eller deprofessionalisering? Positioneringar och samspel i ett dilemmatic space. I C. Gustafsson \& G. Fransson (Red.), Kvalificerad som lärare? Om professionell utveckling, mentorskap och bedömning med sikte på lärarlegitimation. Gävle: Gävle University Press.

Fransson, G. (2017). Understanding morality and ethics: Maneuvering ethical dilemmas in digital educational contexts. I O. Dreon \& D. Polly (Red.), Teacher Education for Ethical Professional Practice in the 21st Century. Hershey: IGI Global.

Fransson, G., \& Grannäs, J. (2013). Dilemmatic spaces in educational contextstowards a conceptual framework for dilemmas in teachers work. Teachers and Teaching, 19(1), 4-17.

Frelin, A. (2013). Att hantera läraryrkets komplexitet(er)-en grund för professionalitet?. Utbildning \& Demokrati, 22(1), 7-27.

Garnett, R. F., \& Vanderlinden, L. K. (2011). Reflexive pedagogy: disciplinary idioms as resources for teaching. Teaching in Higher Education, 16(6), 629640 .

Gibbons, P. (2013). Stärk språket stärk lärandet. Språk- och kunskapsutvecklande arbetssätt för och med andraspråkselever i klassrummet. Stockholm: Hallgren \& Fallgren.

Giddens, A. (1990). The consequences of modernity. Cambridge: Polity Press.

Gomm, R., Hammersley, M., \& Foster, P. (Red.), (2000). Case study method: Key issues, key texts. London: Sage.

Granström, K. (2007). Ledarskap i klassrummet. I K. Granström (Red.), Forskning om lärares arbete i klassrummet. Stockholm: Myndigheten för skolutveckling.

Gren Landell, M. (2014) Orolig och blyg i skolan: Att möta elever med vanliga och osynliga problem. Stockholm: Natur \& Kultur.

Haavisto, V. (2002). Court work in transition: An activity-theoretical study of changing work practices in a Finnish district court. Helsingfors: Helsingfors universitet.

Hasslöf, H. (2015). The educational challenge in " education for sustainable development": Qualification, social change and the political (Doktorsavhandling). Malmö: Malmö högskola.

Hasslöf, H., \& Malmberg, C. (2015). Critical thinking as room for subjectification in education for sustainable development. Environmental Education Research, 21(2): 239-255.

Healey, M. (2005). Linking research and teaching exploring disciplinary spaces and the role of inquiry-based learning. I R. Barnett (Red.), Reshaping the 
university: new relationships between research, scholarship and teaching. Maidenhead: McGraw-Hill/Open University Press.

Herr, K., \& Andersen, G. L. (2005). The action research dissertation: A guide for students and faculty. London: Sage.

Hess, D. E. (2009). Controversy in the classroom: The democratic power of discussion. New York: Routledge.

Hirsh, Å. (2017) Formativ undervisning: Utveckla klassrumspraktiker med lärandet $\mathrm{i}$ fokus. Stockholm: Natur \& Kultur.

Hodgson, A., \& Spours, K. (2009). Collaborative local learning ecologies: Reflections on the governance of lifelong learning in England. Inquiry into the Future of Lifelong Learning Sector Paper, 6. Leicester: NIACE.

Honig, B. (1994). Difference, dilemmas, and the politics of home. Social Research, 61(3), 563-597.

Holmqvist, M. O., \& Olander, C. (2017). Analysing teachers' operations when teaching students: what constitutes scientific theories?. International Journal of Science Education, 39(7), 840-862.

Huddleston, T., \& Rowe, D. (2015). Discussion in citizenship. I L. Gearon (Red.), Learning to teach citizenship in the secondary school, A companion to school experience. Abingdon: Routledge.

Hundal, S., Levin, D. M., \& Keselman, A. (2014). Lessons of researcher-teacher co-design of an environmental health afterschool club curriculum. International Journal of Science Education, 36(9), 1510-1530.

Hultman, G. (2015). Transformation, interaktion eller kunskapskonkurrens. Forskningsanvändning i praktiken. Stockholm: Vetenskapsrådet.

Ideland, M., \& Malmberg, C. (2015). Governing 'eco-certified children through pastoral power: critical perspectives on education for sustainable development. Environmental Education Research, 21(2), 173-182.

Ingerman, $\AA$., \& Wickman, P.-O. (2015). Towards a teachers' professional discipline: Shared responsibility for didactic models in research and practice. I P. Burnard, B.-M. Apelgren \& N. Cabaroglu (Red.), Transformative Teacher Research: Theory and Practice for the C21st. Rotterdam: Sense.

Ishikawa, K. (1990). Introduction to quality control. Tokyo: 3A Corp.

Jakobsson, A. (2012). Sociokulturella perspektiv på lärande och utveckling: Lärande som begreppsmässig precisering och koordinering. Pedagogisk forskning i Sverige, 17(3-4), 152-170.

Jakobson, B., Lundegård, I., \& Wickman, P.-O. (Red.), (2014). Lärande $i$ handling: en pragmatisk didaktik. Lund: Studentlitteratur.

Jansson, A. (2009). Kommunikation. Malmö: Liber. 
Jensen, B. B., \& Schnack, K. (2006). The action competence approach in environmental education. Environmental education research, 12(3-4), 471-486.

Jonasson Ring, E. (2015). Samhällskunskap i ett föränderligt samhälle: Medborgarkompetenser och didaktiska utmaningar (Licentiatuppsats). Karlstad: Karlstad universitet.

Jönsson, A. (2016, maj). Bedömningsreformen som kom av sig. Skola och Samhälle. Hämtad den 2017-03-09 från http://www.skolaochsamhalle.se/flode/skolpolitik/anders-jonsson-bedomningsreformen-som-kom-avsig/

Keogh, B. \& Naylor, S. (1999). Concept cartoons, teaching and learning in science: an evaluation. International Journal of Science Education, 21(4), 431446.

Kerr, D. (2000). The making of citizenship in the National Curriculum (England): issues and challenges. I Paper presented at the European Conference on Educational Research (Vol. 20). Berlin: European Educational Research Association.

Keirl, S. (2012). Technology education as 'controversy celebrated' in the cause of democratic education. I T. Ginner, J. Hallström \& M. Hultén (Red.), PATT 26 Conference; Technology Education in the 21st Century; Stockholm; Sweden; 26-30 June; 2012. Linköping: Linköpings universitet.

Klafki, W. (1995). Didactic analysis as the core of preparation of instruction. Journal of Curriculum Studies, $27(1), 13-30$.

Kopnina, H. (2012). Education for sustainable development (ESD): the turn away from 'environment' in environmental education?. Environmental Education Research, 18(5), 699-717.

Kvale, S., \& Brinkmann, S. (2009). Den kvalitativa forskningsintervjun. Lund: Studentlitteratur.

Langelotz, L. (2016). Kollegorna stöttar, utvecklar - och dömer. Pedagogiska magasinet, 1, 46-49.

Larsson, S. (2005). Om kvalitet i kvalitativa studier. Nordisk pedagogik, 25(1), $16-35$.

Leontiev, A. N. (1978). Verksamhet, medvetande och personlighet. Göteborg: Fram.

Lincoln, Y. S., \& Guba, E. G. (1985). Naturalistic inquiry. Beverly Hills: Sage.

Lindahl, M. (2016, 7 maj). Tänka själv eller tänka som andra - svårigheten att diskutera naturvetenskap i ett samhällsperspektiv [Videofil]. Hämtad från https://lnu.se/personal/mats.lindahl/

Lindvall, J. (2016, 10 december). Konflikternas mellanväg. Sydsvenska Dagbladet. Hämtad från https://www.sydsvenskan.se/2016-12-10/konflikternasmellanvag 
Ligozat, F., Amade-Escot, C., \& Östman, L. (2015). Beyond subject specific approaches of teaching and learning: Comparative didactics. Interchange, 46(4), 313-321.

Ljunggren, C. (2008). Det offentliga rummets princip: -om kontroversiella frågor i utbildningen. Norsk pedagogisk tidskrift, 92(4), 316-327.

Ljunggren, C., \& Unemar Öst, I. (2010). Skolors och lärares kontrovershantering. I E. Amnå, T. Englund, C. Arensmeier, J. Ekman, C. Ljunggren, I. Unemar Öst \& P. Zetterberg (Red), Skolor som politiska arenor: medborgarkompetens och kontrovershantering: internationella studier. Stockholm: Skolverket.

Ljunggren, C., \& Unemar Öst, I. (2011). Teachers' dealings with controversial issues: a typology from the 2009 IEA/ICCS study. Politics, culture and socialization, 2(3). 273-294.

Ljunggren, C., Unemar Öst, I., \& Englund, T. (2015). Controversial issues education - på svenska. I C. Ljunggren, I. Unemar Öst \& T. Englund (Red.), Kontroversiella frågor: Om kunskap och politik $i$ samhällsundervisningen. Malmö: Gleerups.

Lundegård, I. (2007). På väg mot pluralism: Elever i situerade samtal kring hållbar utveckling. Stockholm: HLS Förlag.

Lundegård, I., \& Wickman, P.-O. (2012). It takes two to tango: Studying how students constitute political subjects in discourses on sustainable development. Environmental Education Research 18 (2), 153-169.

Mannion, G., Biesta, G., Priestley, M., \& Ross, H. (2011). The global dimension in education and education for global citizenship: Genealogy and critique. Globalisation, Societies and Education, 9(3-4), 443-456.

Miller-Lane, J., Denton, E., \& May, A. (2006). Social studies teachers' views on committed impartiality and discussion. Social Studies Research and Practice, 1(1), 30-44.

Mitchell, D., \& Ashing, K. (2015). Inkludering i skolan: undervisningsstrategier som fungerar. Stockholm: Natur \& Kultur.

Mouffe, C. (1999). Deliberative democracy or agonistic pluralism? Social research, 66, 745-758.

Nationalencyklopedin, reflexivitet. http://www.ne.se/uppslagsverk/encyklopedi/lång/reflexivitet (hämtad 2016-12-20)

Nielsen, J. A. (2012a). Co-opting science: A preliminary study of how students invoke science in value-laden discussions. International Journal of Science Education, 34(2), 275-299.

Nielsen, J. A. (2012b). Science in discussions: An analysis of the use of science content in socioscientific discussions. Science education, 96(3), 428-456. 
Null, W. (2011). Curriculum: From theory to practice. Lanham: Rowman \& Littlefield Publishers, Inc.

Olsson, R. (2016). Samhällskunskap som ämnesförståelse och undervisningsämne: Prioriteringar och nyhetsanvändning hos fyra gymnasielärare (Doktorsavhandling). Karlstad: Karlstads universitet.

Olsson Jers, C. (2010). Klassrummet som muntlig arena. Att bygga och etablera ethos (Doktorsavhandling). Malmö: Malmö högskola.

Osborne, J., \& Dillon, J. (2008). Science education in Europe: Critical reflections. London: The Nuffield Foundation.

Ottander, K. (2015). Gymnasieelevers diskussioner utifrån hållbar utveckling: Meningsskapande, Naturkunskapande, Demokratiskapande(Doktorsavhandling). Umeå: Umeå universitet.

Pavlova, M. (2013). Teaching and learning for sustainable development: ESD research in technology education. International Journal of Technology and Design Education, 23(3), 733-748.

Pavlova, M. (2015). Design and technology education for sustainable future. I K. Stables \& S. Keirl (Red.), Environment, Ethics and Cultures: Design and Technology Education's Contribution to Sustainable Global Futures. Rotterdam: Sense.

Pedretti, E. (1999). Decision making and STS education: Exploring scientific knowledge and social responsibility in schools and science centers through an issues-based approach. School Science and Mathematics, 99(4), 174-181.

Pedretti, E., \& Nazir, J. (2011). Currents in STSE education: Mapping a complex field, 40 years on. Science education, 95(4), 601-626.

Pickering, A. (1995). The mangle of practice. [Elektronisk resurs]: time, agency, and science. Chicago: University of Chicago Press.

Presley, M. L., Sickel, A. J., Muslu, N., Merle-Johnson, D., Witzig, S. B., Izci, K., \& Sadler, T. D. (2013). A framework for socio-scientific issues based education. Science Educator, 22(1), 26-32.

Ratcliffe, M., \& Grace, M. (2003). Science education for citizenship. Maidenhead: Open University Press.

Ratcliffe, M., Bartholomew, H., Hames, V., Hind, A., Leach, J., Millar, R., \& Osborne, J. (2005). Evidence-based practice in science education: the researcher-user interface. Research Papers in Education, 20(2), 169-186

Reid, W. A. (2006). The pursuit of curriculum: Schooling and the public interest. Greenwich: IAP.

Roberts, D. A. (1982). Developing the concept of "curriculum emphases" in science education. Science education, 66(2), 243-260. 
Roberts, D. A. (2007) Scientific literacy/Science Literacy. I S. K. Abell \& N. J. Lederman (Red.), Handbook of Research in Science Education. Mahwah: Lawrence Erlbaum Ass.

Roberts, D. A., \& Östman, L. (1998). Problems of meaning in science curriculum. New York: Teachers College Press.

Robottom, I. (2012). Socio-Scientific issues in education: Innovative practices and contending epistemologies. Research in Science Education, 42(1), 95107.

Robson, C. (2011). Real world research: a resource for users of social research methods in applied settings. Chichester: Wiley.

Rolf, B. (2006). Tre kunskapsmodeller. I A. Bronäs \& S. Selander (Red.), Verklighet verklighet: Teori och praktik i lärarutbildning. Stockholm: Nordstedts Akademiska förlag.

Roth, W. M., \& Tobin, K. (2002). Redesigning an" urban" teacher education program: An activity theory perspective. Mind, Culture, and Activity, 9(2), 108-131.

Rundgren, C.-J. (2006). Att börja tala 'biokemiska'-Betydelsen av metaforer och hjälpord för meningsskapande kring proteiner. Nordic Studies in Science Education, 1(5), 30-42.

Runfors, A. (2003). Mångfald, motsägelser och marginaliseringar: En studie av hur invandrarskap formas i skolan (Doktorsavhandling). Stockholm: Prisma.

Samuelsson, M., \& Colnerud, G. (2015). Student teachers' perceptions regarding the challenges of leadership. I D. Garbett \& A. Ovens (Red.), Teaching for tomorrow today. Auckland; International Association of Teachers and Teaching (ISATT) and Edify Ltd.

Sadler, T. D., \& Zeidler, D. L. (2009). Scientific literacy, PISA, and socioscientific discourse: Assessment for progressive aims of science education. Journal of Research in Science Teaching, 46(8), 909-921.

Samuelsson, J., \& Engwall, M. (2008). Nya villkor för lärarutbildningen. I A. Engström (Red), Att erövra världen. Grundläggande färdigheter i läsning; skrivning och matematik; 26-27 november 2007. Linköping: Linköpings universitet.

Sandström Madsén, I. (2007). Samtala, läsa och skriva för att lära: $i$ ett utvecklingsperspektiv från förskola till högskola. Kristianstad: Högskolan i Kristianstad.

Sannino, A., \& Nocon, H. (2008). Special issue editors' introduction: Activity theory and school innovation. Journal of Educational Change, 9(4), 325328.

Schön, D. (1983) The Reflective Practitioner. How professionals think in action. New York: Basic Books Inc. Publishers. 
Shulman, L. S. (1986). Those who understand: Knowledge growth in teaching. Educational researcher, 15(2), 4-14.

Simonneaux, L. (2014a). From promoting the Techno-sciences to activism - A variety of objectives involved in their teaching of SSIs. I L. Bencze \& S. Alsop (Red.), Activist Science and Technology Education. Dordrecht: Springer

Simonneaux, L. (2014b). Questions socialement vives and socio-scientific issues: New trends of research to meet the training needs of postmodern society. I C. Bruguiére, A. Tiberghien, \& P. Clement (Red.), Topics and Trends in Current Science Education. Dordrecht: Springer.

Seel, H. (1999). Didaktik as the professional science of the teachers. TNTEE Publications, 2(1), 85-93.

Sjöström, J. (2013). Towards Bildung-oriented chemistry education. Science \& Education, 22(7), 1873-1890.

Sjöström, J. (2018). Science teacher identity and eco-transformation of science education: comparing Western modernism with Confucianism and reflexive Bildung. Cultural Studies of Science Education, 13(1), 147-161.

Sjöström, J. (under utgivning). Bildning som didaktisk ledstjärna, I E. Insulander \& S. Selander (red.) Att bli lärare. Stockholm: Liber.

Sjöström, J., \& Eilks, I. (2018). Reconsidering different visions of scientific literacy and science education based on the concept of Bildung. I Y. J. Dori, Z. Mevarech, \& D. Baker (Red.), Cognition, Metacognition, and Culture in STEM Education. Dordrecht: Springer.

Sjöström, J., Eilks, I., \& Zuin, V. G. (2016). Towards eco-reflexive science education. Science \& Education, 25(3-4), 321-341.

Sjöström, J., Frerichs, N., Zuin, V. G., \& Eilks, I. (2017). Use of the concept of Bildung in the international science education literature, its potential, and implications for teaching and learning, Studies in Science Education, 53(2), 165-192.

Skolverket (2009). Vad påverkar resultaten i svensk grundskola?: kunskapsöversikt om betydelsen av olika faktorer: sammanfattande analys. Stockholm: Fritze.

SOU 2004: 104. Att lära för hållbar utveckling. Stockholm: Fritze.

Steiner, I. D. (1972). Group processes and group productivity. New York: Academic Press.

Stradling, R., Baines, B., \& Noctor, M. (1984). Teaching controversial issues. London: Hodder Arnold.

Strömquist, S. (1992). Tal och samtal - en inledning. I S. Strömquist (Red.), Tal och samtal. Lund: Studentlitteratur.

Strömquist, S. (2008). Konsten att tala och skriva. Malmö: Gleerups. 
Stuckey, M., Hofstein, A., Mamlok-Naaman, R., \& Eilks, I. (2013). The meaning of 'relevance' in science education and its implications for the science curriculum. Studies in Science Education, 49(1), 1-34.

Sundberg, D. (2015). Läroplansmodeller i den svenska läroplansutvecklingen. I N. Wahlström (Red.), Läroplansteori och didaktik. Malmö: Gleerups.

Svennevig, J. (2001). Abduction as a methodological approach to the study of spoken interaction. Norskrift, 103, 1-22.

Tidemand, S., \& Nielsen, J. A. (2017). The role of socioscientific issues in biology teaching: from the perspective of teachers. International Journal of Science Education, 39(1), 44-61.

Todd, S. (2010). Can there be pluralism without conflict?. Philosophy of Education Yearbook. 2009, 51-59.

Toulmin, S. (1958). The uses of argument. Cambridge: Cambridge University Press.

Tryggvason, Á. (2015). Politiska frågor i klassrummet. I Ljunggren, C., Unemar Öst, I. \& Englund, T. (Red.), Kontroversiella frågor: Om kunskap och politik i samhällsundervisningen. Malmö: Gleerups.

Uljens, M. (2014). Pedagogik, filosofi och politik - Studier i pedagogisk handlingsteori, Pedagogiska fakulteten, Åbo Akademi

Universitets- och högskolerådet. (2016). Erasmus+ strategiska partnerskap skola. Hämtad 2016-10-13, från http://utbyten.se/sv/Program/Program-A--O/Erasmus-strategiska-partnerskap-skola/

Vetenskapsrådet (2011). God forskningssed. Stockholm: Vetenskapsrådet.

Wahlström, N. (2015). Läroplansteori och didaktik. Malmö: Gleerups.

Weber, M. (2008). Max Weber's Complete Writings on Academic and Political Vocations. New York: Algora Publishing.

Wibeck, V. (2010). Fokusgrupper: om fokuserade gruppintervjuer som undersökningsmetod. Lund: Studentlitteratur.

Wickman, P.-O. (2012). Using pragmatism to develop didactics in Sweden. Zeitschrift für Erziehungswissenschaft, 15(3), 483-501.

Wickman, P.-O. (2014). Teaching Learning Progressions. I N. G. Lederman \& S. K. Abell (Red.), Handbook of Research on Science Education, Volume II. New York: Routledge.

Wiliam, D. (2009). Assessment for learning: why, what and how?. London: UCL IOE Press.

Zeidler, D. L., \& Keefer, M. (2003). The role of moral reasoning and the status of socioscientific issues in science education. I D. L. Zeidler (Red.), The role of moral reasoning on socioscientific issues and discourse in science education. Dordrecht: Springer. 
Zeidler, D. L., Sadler, T. D., Simmons, M. L., \& Howes, E. V. (2005). Beyond STS: A Research-Based Framework for Socioscientific Issues Education. Science education, 89(3), 357-377.

Zeidler, D.L. (2014). Socioscientific issues as a curriculum emphasis: Theory, research and practice. I N. G. Lederman \& S. K. Abell (Red.), Handbook of Research on Science Education, Volume II. New York: Routledge.

Zeidler, D. L., \& Kahn, S. (2014). It's debatable. Using socio-scientific issues to develop scientific literacy. Arlington: National Science Teachers Association.

Åkerblom, D., \& Lindahl, M. (2017). Authenticity and the relevance of discourse and figured worlds in secondary students' discussions of socioscientific issues. Teaching and Teacher Education, 65, 205-214.

Öhman, J. (2003). Miljödidaktisk forskning och selektiva traditioner i skolans miljöundervisning-en jämförelse. I L. Östman (Red.), Nationell och internationell miljödidaktisk forskning. En forskningsöversikt. Uppsala: Uppsala universitet.

Öhman, M., \& Öhman, J. (2012). Harmoni eller konflikt? - en fallstudie av meningsinnehållet i utbildning för hållbar utveckling. Nordic Studies in Science Education, 8(1), 59-72.

Österlind, E. (2010). Eget arbete i backspegeln. I I. Eriksson, V. Lindberg, E. Österlind (Red.), Uppdrag undervisning: Kunskap och lärande. Lund: Studentlitteratur.

Östman, L. (1995). Socialisation och mening: No-utbildning som politiskt och miljömoraliskt problem (Doktorsavhandling). Uppsala: Uppsala universitet. 


\section{BILAGOR}

Bilagor finns publicerade elektroniskt på:

http://doi.org/10.24834/2043/24738 


\section{Studies in Science and Technology Education ISSN 1652-5051 FontD}

1. Margareta Enghag (2004): MINIPROJECTS AND CONTEXT RICH PROBLEMS - Case studies with qualitative analysis of motivation, learner ownership and competence in small group work in physics. (licentiate thesis) Linköping University

2. Carl-Johan Rundgren (2006): Meaning-Making in Molecular Life Science Education - upper secondary school students' interpretation of visualizations of proteins. (licentiate thesis) Linköping University

3. Michal Drechsler (2005): Textbooks', teachers', and students' understanding of models used to explain acid-base reactions. ISSN: 14038099, ISBN: 91-85335-40-1. (licentiate thesis) Karlstad University

4. Margareta Enghag (2007): Two dimensions of Student Ownership of Learning during Small-Group Work with Miniprojects and context rich Problems in Physics. ISSN: 1651-4238, ISBN: 91-85485-31-4. (Doctoral Dissertation) Mälardalen University

5. Maria Åström (2007): Integrated and Subject-specific. An empirical exploration of Science education in Swedish compulsory schools. (Licentiate thesis) Linköping university

6. Ola Magntorn (2007): Reading Nature: developing ecological literacy through teaching. (Doctoral Dissertation) Linköping University

7. Maria Andreé (2007): Den levda läroplanen. En studie av naturorienterande undervisningspraktiker i grundskolan. ISSN: 1400-478X, HLS Förlag: ISBN 978-91-7656-632-9 (Doctoral Dissertation, LHS)

8. Mattias Lundin (2007): Students' participation in the realization of school science activities. (Doctoral Dissertation) Linköping University

9. Michal Drechsler (2007): Models in chemistry education. A study of teaching and learning acids and bases in Swedish upper secondary schools ISBN 978-91-7063-112-2 (Doctoral Dissertation) Karlstad University

10. Proceedings from FontD Vadstena-meeting, April 2006.

11. Eva Blomdahl (2007): Teknik i skolan. En studie av teknikundervisning för yngre skolbarn. ISSN: 1400-478X, HLS Förlag: ISBN 97891-7656-635-0 (Doctoral Dissertation, LHS)

12. Iann Lundegård (2007): På väg mot pluralism. Elever i situerade samtal kring hållbar utveckling. ISSN:1400-478X, HLS Förlag: ISBN 978-91-7656-642-8 (Doctoral Dissertation, LHS)

13. Lena Hansson (2007): "Enligt fysiken eller enligt mig själv?" - Gymnasieelever, fysiken och grundantaganden om världen. (Doctoral Dissertation) Linköping University.

14. Christel Persson (2008): Sfärernas symfoni i förändring? Lärande i miljö för hållbar utveckling med naturvetenskaplig utgångspunkt. En longitudinell studie i grundskolans tidigare årskurser. (Doctoral Dissertation) Linköping University 
15. Eva Davidsson (2008): Different Images of Science - a study of how science is constituted in exhibitions. ISBN: 978-91-977100-1-5 (Doctoral Dissertation) Malmö University

16. Magnus Hultén (2008): Naturens kanon. Formering och förändring av innehållet i folkskolans och grundskolans naturvetenskap 18422007. ISBN: 978-91-7155-612-7 (Doctoral Dissertation) Stockholm University

17. Lars-Erik Björklund (2008): Från Novis till Expert: Förtrogenhetskunskap i kognitiv och didaktisk belysning. (Doctoral Dissertation) Linköping University.

18. Anders Jönsson (2008): Educative assessment for/of teacher competency. A study of assessment and learning in the "Interactive examination" for student teachers. ISBN: 978-91-977100-3-9 (Doctoral Dissertation) Malmö University

19. Pernilla Nilsson (2008): Learning to teach and teaching to learn - primary science student teachers' complex journey from learners to teachers. (Doctoral Dissertation) Linköping University

20. Carl-Johan Rundgren (2008): VISUAL THINKING, VISUAL SPEECH - a Semiotic Perspective on Meaning-Making in Molecular Life Science. (Doctoral Dissertation) Linköping University

21. Per Sund (2008): Att urskilja selektiva traditioner i miljöundervisningens socialisationsinnehåll - implikationer för undervisning för hållbar utveckling. ISBN: 978-91-85485-88-8 (Doctoral Dissertation) Mälardalen University

22. Susanne Engström (2008): Fysiken spelar roll! I undervisning om hållbara energisystem - fokus på gymnasiekursen Fysik A. ISBN: 978-91-85485-96-3 (Licentiate thesis) Mälardalen University

23. Britt Jakobsson (2008): Learning science through aesthetic experience in elementary school science. Aesthetic judgement, metaphor and art. ISBN: 978-91-7155-654-7. (Doctoral Dissertation) Stockholm university

24. Gunilla Gunnarsson (2008): Den laborativa klassrumsverksamhetens interaktioner - En studie om vilket meningsskapande år 7-elever kan erbjudas i möten med den laborativa verksamhetens instruktioner, artefakter och språk inom elementär ellära, samt om lärares didaktiska handlingsmönster i dessa möten. (Doctoral Dissertation) Linköping University

25. Pernilla Granklint Enochson (2008): Elevernas föreställningar om kroppens organ och kroppens hälsa utifrån ett skolsammanhang. (Licentiate thesis) Linköping University

26. Maria Åström (2008): Defining Integrated Science Education and putting it to test (Doctoral Dissertation) Linköping University

27. Niklas Gericke (2009): Science versus School-science. Multiple models in genetics - The depiction of gene function in upper secondary textbooks and its influence on students' understanding. ISBN 97891-7063-205-1 (Doctoral Dissertation) Karlstad University

28. Per Högström (2009): Laborativt arbete i grundskolans senare år lärares mål och hur de implementeras. ISBN 978-91-7264-755-8 (Doctoral Dissertation) Umeå University 
29. Annette Johnsson (2009): Dialogues on the Net. Power structures in asynchronous discussions in the context of a web based teacher training course. ISBN 978-91-977100-9-1 (Doctoral Dissertation) Malmö University

30. Elisabet M. Nilsson (2010): Simulated "real" worlds: Actions mediated through computer game play in science education. ISBN 97891-86295-02-8 (Doctoral Dissertation) Malmö University

31. Lise-Lotte Österlund (2010): Redox models in chemistry: A depiction of the conceptions held by upper secondary school students of redox reactions. ISBN 978-91-7459-053-1 (Doctoral Dissertation) Umeå University

32. Claes Klasander (2010): Talet om tekniska system - förväntningar, traditioner och skolverkligheter. ISBN 978-91-7393-332-2 (Doctoral Dissertation) Linköping University

33. Maria Svensson (2011): Att urskilja tekniska system - didaktiska dimensioner i grundskolan. ISBN 978-91-7393-250-9 (Doctoral Dissertation) Linköping University

34. Nina Christenson (2011): Knowledge, Value and Personal experience - Upper secondary students' use of supporting reasons when arguing socioscientific issues. ISBN 978-91-7063-340-9 (Licentiate thesis) Karlstad University

35. Tor Nilsson (2011): Kemistudenters föreställningar om entalpi och relaterade begrepp. ISBN 978-91-7485-002-4 (Doctoral Dissertation) Mälardalen University

36. Kristina Andersson (2011): Lärare för förändring - att synliggöra och utmana föreställningar om naturvetenskap och genus. ISBN 97891-7393-222-6 (Doctoral Dissertation) Linköping University

37. Peter Frejd (2011): Mathematical modelling in upper secondary school in Sweden An exploratory study. ISBN: 978-91-7393-223-3 (Licentiate thesis) Linköping University

38. Daniel Dufäker (2011): Spectroscopy studies of few particle effects in pyramidal quantum dots. ISBN 978-91-7393-179-3 (Licentiate thesis) Linköping University

39. Auli Arvola Orlander (2011): Med kroppen som insats: Diskursiva spänningsfält i biologiundervisningen på högstadiet. ISBN 978-917447-258-5 (Doctoral Dissertation) Stockholm University

40. Karin Stolpe (2011): Att uppmärksamma det väsentliga. Lärares ämnesdidaktiska förmågor ur ett interaktionskognitivt perspektiv. ISBN 978-91-7393-169-4 (Doctoral Dissertation) Linköping University

41. Anna-Karin Westman (2011) Samtal om begreppskartor - en väg till ökad förståelse. ISBN 978-91-86694-43-2 (Licentiate thesis) Mid Sweden University

42. Susanne Engström (2011) Att vördsamt värdesätta eller tryggt trotsa. Gymnasiefysiken, undervisningstraditioner och fysiklärares olika strategier för energiundervisning. ISBN 978-91-7485-011-6 (Doctoral Dissertation) Mälardalen University

43. Lena Adolfsson (2011) Attityder till naturvetenskap. Förändringar av flickors och pojkars attityder till biologi, fysik och kemi 1995 till 2007. ISBN 978-91-7459-233-7 (Licentiate thesis) Umeå University 
44. Anna Lundberg (2011) Proportionalitetsbegreppet i den svenska gymnasie-matematiken - en studie om läromedel och nationella prov. ISBN 978-91-7393-132-8 (Licentiate thesis) Linköping University

45. Sanela Mehanovic (2011) The potential and challenges of the use of dynamic software in upper secondary Mathematics. Students' and teachers' work with integrals in GeoGebra based environments. ISBN 978-91-7393-127-4 (Licentiate thesis) Linköping University

46. Semir Becevic (2011) Klassrumsbedömning i matematik på gymnasieskolans nivå. ISBN 978-91-7393-091-8 (Licentiate thesis) Linköping University

47. Veronica Flodin (2011) Epistemisk drift - genbegreppets variationer i några av forskningens och undervisningens texter i biologi. ISBN 978-91-9795-161-6 (Licentiate thesis) Stockholm University

48. Carola Borg (2011) Utbildning för hållbar utveckling ur ett lärarperspektiv -Ämnesbundna skillnader i gymnasieskolan. ISBN 978-917063-377-5 (Licentiate thesis) Karlstad University

49. Mats Lundström (2011) Decision-making in health issues: Teenagers' use of science and other discourses. ISBN 978-91-86295-15-8 (Doctoral Dissertation) Malmö University

50. Magnus Oscarsson (2012) Viktigt, men inget för mig. Ungdomars identitetsbygge och attityd till naturvetenskap. ISBN: 978-91-7519988-7 (Doctoral Dissertation) Linköping University

51. Pernilla Granklint Enochson (2012) Om organisation och funktion av människo-kroppens organsystem - analys av elevsvar från Sverige och Sydafrika. ISBN 978-91-7519-960-3 (Doctoral Dissertation) Linköping University

52. Mari Stadig Degerman (2012) Att hantera cellmetabolismens komplexitet - Meningsskapande genom visualisering och metaforer. ISBN 978-01-7519-954-2 (Doctoral Dissertation) Linköping University

53. Anna-Lena Göransson (2012) The Alzheimer A $\beta$ peptide: Identification of Properties Distinctive for Toxic Prefibrillar Species. ISBN 978-91-7519-930-6 (Licentiate thesis) Linköping University

54. Madelen Bodin (2012) Computational problem solving in university physics education- Students' beliefs, knowledge, and motivation. ISBN 978-91-7459-398-3 (Doctoral Dissertation) Umeå University

55. Lena Aretorn (2012) Mathematics in the Swedish Upper Secondary School Electricity Program: A study of teacher knowledge. ISBN 97891-7459-429-4 (Licentiate thesis) Umeå University

56. Anders Jidesjö (2012) En problematisering av ungdomars intresse för naturvetenskap och teknik i skola och samhälle - Innehåll, medierna och utbildningens funktion. ISBN 978-91-7519-873-6 (Doctoral Dissertation) Linköping University

57. Thomas Lundblad (2012) Simulerad verklighet i gymnasieskolans fysik: en designstudie om en argumented reality simulering med socionaturvetenskapligt innehåll. ISBN 978-91-7519-854-5 (Licentiate thesis) Linköping University

58. Annie-Maj Johansson (2012) Undersökande arbetssätt i NO-undervisningen $i$ grundskolans tidigare årskurser. ISBN 978-91-7447-5524 (Doctoral Dissertation) Stockholm University 
59. Anna Jobér (2012) Social Class in Science Class. ISBN 978-9186295-31-8 (Doctoral Dissertation) Malmö University

60. Jesper Haglund (2012) Analogical reasoning in science education connections to semantics and scientific modeling in thermodynamics. ISBN 978-91-7519-773-9 (Doctoral Dissertation) Linköping University

61. Fredrik Jeppsson (2012) Adopting a cognitive semantic approach to understand thermodynamics within science education. ISBN 978-917519-765-4 (Doctoral Dissertation) Linköping University

62. Maria Petersson (2012) Lärares beskrivningar av evolution som undervisningsinnehåll i biologi på gymnasiet. ISBN 978-91-7063453-6 (Doctoral Dissertation) Karlstad University

63. Henrik Carlsson (2012) Undervisningsform, klassrumsnormer och matematiska förmågor. En studie av ett lokalt undervisningsförsök för elever med intresse och fallenhet för matematik. ISBN 978-9186983-89-5 (Licentiate thesis) Linnaeus University)

64. Anna Bergqvist (2012) Models of Chemical Bonding. Representations Used in School Textbooks and by Teachers and their Relation to Students' Understanding. ISBN 978-91-7063-463-5 (Licentiate thesis) Karlstad University

65. Nina Kilbrink (2013) Lära för framtiden: Transfer i teknisk yrkesutbildning. ISBN 978-91-7063-478-9 (Doctoral Dissertation) Karlstad University

66. Caroline Larsson (2013) Experiencing Molecular Processes. The Role of Representations for Students' Conceptual Understanding. ISBN 978-91-7519-607-7 (Doctoral Dissertation) Linköping University

67. Anna-Karin Carstensen (2013) Connect Modelling Learning to Facilitate Linking Models and the Real World through Labwork in Electric Circuit Courses for Engineering Students ISBN 978-91-7519562-9 (Doctoral Dissertation) Linköping University

68. Konferensproceeding: 10-year Anniversary Meeting with the Scientific Committee

69. Marie Bergholm (2014) Gymnasieelevers kommunikativa strategier i matematikklassrummet. En fallstudie av ett smågruppsarbete om derivata ISBN 978-91-7519-306-9 (Licentiate thesis) Linköping University

70. Ingrid Lundh (2014) Undervisa Naturvetenskap genom Inquiry - En studie av två högstadielärare. ISBN 978-91-7519-285-7 (Licentiate thesis) Linköping University

71. Nils Boman (2014) Personality traits in fish - implications for invasion biology

ISBN:978-91-7601-097-6 (Licentiate thesis) Umeå University

72. Torodd Lunde (2014) När läroplan och tradition möts - lärarfortbildning och syften med undersökande aktiviteter inom den laborativa NO-undervisningen i grundskolans senare del. ISBN: 978-917063-577-9 (Licentiate thesis) Karlstad University

73. Martin Eriksson (2014) Att ta ställning - gymnasieelevers argumentation och beslutsfattande om sociovetenskapliga dilemman. ISBN 978-91-7063-588-5 (Licentiate thesis), Karlstad University 
74. Annalena Holm (2014) Mathematics Communication within the Frame of Supplemental Instruction. Identifying Learning Conditions. ISBN 978-91-7623-112-8 (Licentiate thesis) Lund University

75. Daniel Olsson (2014) Young people's 'Sustainability Consciousness' - Effects of ESD implementation in Swedish schools. ISBN 978-917063-594-6. (Licentiate thesis) Karlstad University

76. Marlene Sjöberg (2014) Möjligheter I kollegiala samtal om NOundervisning och bedömning. https://gupea.ub.gu.se/handle/2077/24063 (Licentiate thesis) Gothenburg University.

77. Teresa Berglund (2014) Student 'Sustainability Consciousness' and Decision-Making on Sustainability Dilemmas. Investigating effects of implementing education for sustainable development in Swedish upper secondary schools. ISBN 978-91-7063-599-1 (Licentiate thesis) Karlstad University

78. Elisabet Mellroth (2014) High achiever! Always a high achiever? A comparison of student achievements on mathematical tests with different aims and goals. ISBN 978-91-7063-607-3 (Licentiate thesis) Karlstad University

79. Jenny Green (2014) Elevers användande av formativ återkoppling i matematik. ISBN 978-91-7519-164-5 (Licentiate thesis) Linköping University

80. Klara Kerekes (2014) Undervisning om växande geometriska mönster- en variationsteoretisk studie om hur lärare behandlar ett matematiskt innehåll på mellanstadiet. ISBN: 978-91-7519-135-5 (Licentiate thesis) Linköping University

81. Cecilia Axell (2015) Barnlitteraturens tekniklandskap: en didaktisk vandring från Nils Holgersson till Pettson och Findus. ISBN 978-917519-227-7 (Doctoral Dissertation) Linköping University.

82. Jan Forsgren (2015) Synthesis and characterization of catalysts for hydrogen production from water ISBN 978-91-7601-206-2.(Licentiate thesis) Umeå University

83. Maria Eriksson (2015) Att kommunicera naturvetenskap i nationella prov: En studie med andraspråksperspektiv. ISBN 978-91-7519-1386 (Licentiate thesis) Linköping University

84. Tomas Jemsson (2015) Time correlated single photon spectroscopy on pyramidal quantum dots. ISBN 978-91-7519-143-0 (Licentiate thesis) Linköping University

85. Helen Hasslöf (2015) The Challenge of Education for Sustainable Development. Qualification, social change and the political ISBN: 978-91-7519-127-0 (Doctoral Dissertation) Linköping University.

86. Johan Sidenvall (2015) Att lära sig resonera - Om elevers möjligheter att lära sig resonera matematiskt. ISBN 978-91-7519-100-3 (Licentiate thesis) Linköping University.

87. Jonas Jäder (2015) Elevers möjligheter till lärande av matematiska resonemang. ISBN 978-91-7519-099-0 (Licentiate thesis) Linköping University. 
88. Laurence Russell (2015) Exploring systematic lesson variation -a teaching method in mathematics. ISBN 978-91-7519-041-9 (Licentiate thesis) Linköping University.

89. Roger Andersson (2015). Ett lysande experiment. En studie av lärandeprogressionen vid lärande med datorstöd i optik. ISBN 978-917485-215-8 (Licentiate thesis) Mälardalen University.

90. Therese Granekull (2015). Kamratbedömning i naturvetenskap på mellanstadiet - formativ återkoppling genom gruppsamtal. ISBN: 978-91-86295-74-5

(Licentiate thesis) Malmö högskola.

91. Yukiko Asami-Johansson (2015) Designing Mathematics Lessons Using Japanese Problem Solving Oriented Lesson Structure. A Swedish Case Study. ISBN. 978-91-7685-990-2 (Licentiate thesis) Linköping University.

92. Katarina Ottander (2015). Gymnasieelevers diskussioner utifrån hållbar utveckling. Meningsskapande, naturkunskapande, demokratiskapande. ISBN 978-91-7601-322-9 (Doctoral Dissertation) Umeå University

93. Lena Heikka (2015) Matematiklärares målkommunikation - En jämförelse av elevernas uppfattningar, lärarens beskrivningar och den realiserade undervisningen. ISBN: 978-91-7583-446-7 (Licentiate thesis) Luleå University of Technology.

94. Anette Pripp (2016) Välja teknik? Ungdomars röster om valet till gymnasiets teknikprogram. ISBN 978-91-7685-775-5 (Licentiate thesis) Linköping University.

95. Annika Pettersson (2016) Grafisk och algebraisk representation: Gymnasieelevers förståelse av linjära funktioner. ISBN 978-91-7063705-6 (Licentiate thesis) Karlstad University.

96. Erika Boström (2017) Formativ bedömning: En enkel match eller en svår utmaning? Effekter av en kompetensutvecklingssatsning på lärarnas praktik och på elevernas prestationer i matematik. ISBN 97891-7601-706-7 (Doctoral Dissertation) Umeå University.

97. Gustav Bohlin (2017) Evolving germs - Antibiotic resistance and natural selection in education and public communication. ISBN: 978-917685-489-1 (Doctoral Dissertation) Linköping University.

98. Daniel Åkerblom (2018) Meningsfullhet i lärandet - hur kan autenticitet förändra undervisningspraktiken? ISBN: 978-91-88761-19-4 (Licentiate thesis) Linnaeus University.

99. Charlotta Nordlöf (2018) Tekniklärares attityder till teknikämnet och teknikundervisningen. ISBN 978-91-7685-328-3 (Licentiate thesis) Linköping University.

100. Johan Boström (2018) Teknik i förskolan - att motverka traditionella könsroller - En aktionsforskningsstudie. ISBN 978-91-7685-3078 (Licentiate thesis) Linköping University

101. Christian Rydberg (2018) Didaktiska dilemman i undervisning utifrån samhällsdilemman. ISBN 978-91-86295-78-3 (Licentiate thesis) Malmö University 



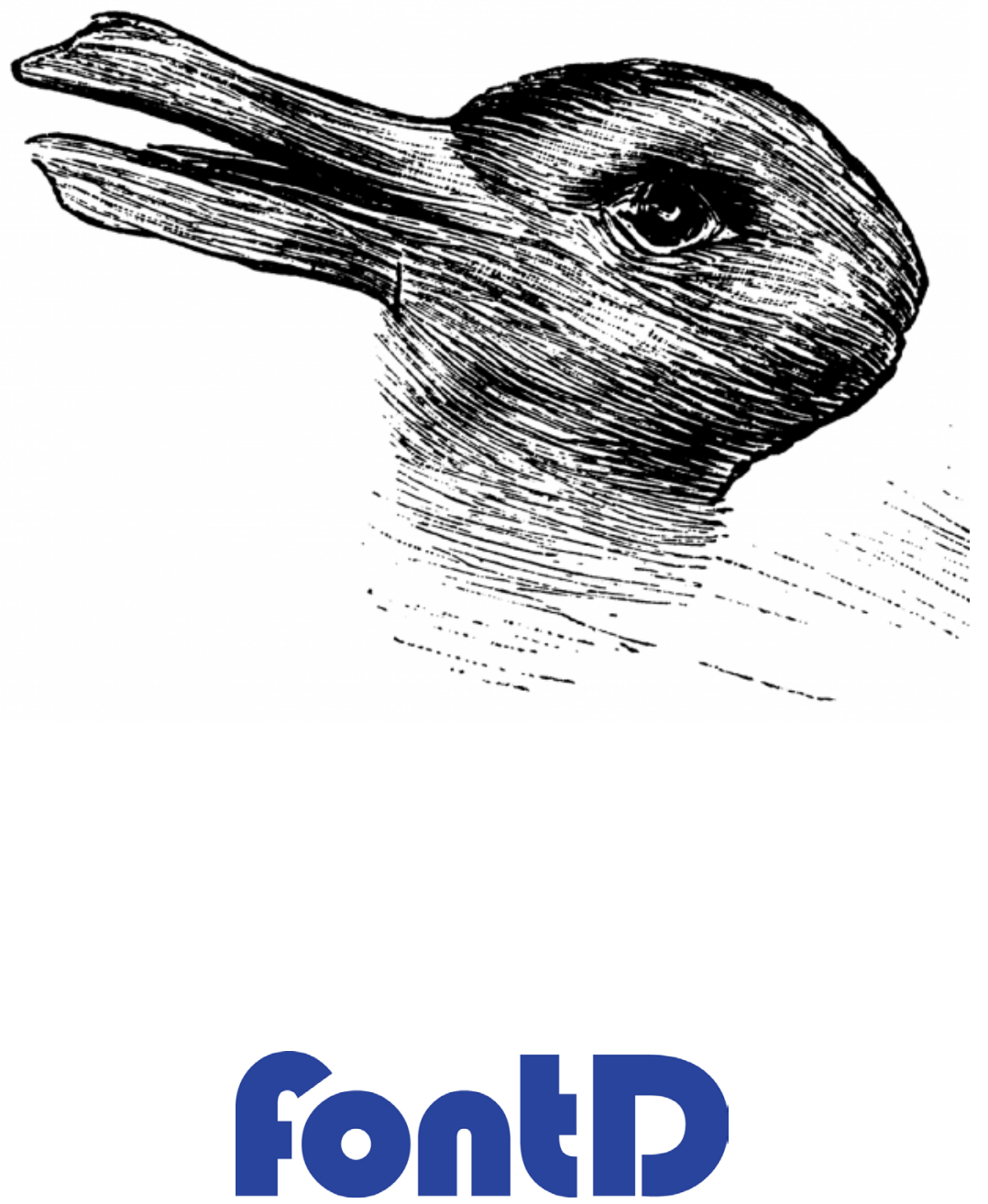

ISBN 978-9I-86295-78-3 (print)

ISBN 978-9I-86295-79-O (pdf)

ISSN I 653-6037 (Malmö universitet)

ISSN I 652-505 I (FontD) 